\title{
GRAVITY SURVEY OF A BURIED TRIASSIC RIFT BASIN IN BERTIE COUNTY, NORTH CAROLINA
}

\author{
by
}

Cody Shell

May, 2020

Director of Thesis: Dr. Eric Horsman

Major Department: Geological Sciences

The North American rift margin includes of a series of Triassic rift basins along the eastern seaboard of the United States and Canada. This continent-scale rift basin system is comprised of complex and variable geometries that can be generalized into regions with similar structural, deformational, and sedimentary characteristics. Rift basins provided accommodation space for organic-rich Triassic age sediments that may be source rocks for natural gas and petroleum. Most of the known basins are exposed at the surface and relatively easy to access, but a few buried basins have been identified beneath coastal plain strata. I used primarily geophysical methods to study a buried Triassic rift basin in Bertie County, North Carolina, recently discovered from a deep core sample that documented Triassic sedimentary rocks buried underneath approximately 300 meters of Cretaceous and younger, sediments and sedimentary rock. Approximately 30 meters of Triassic strata were recovered from the well, but basement rock was not reached leaving the overall thickness of the basin undetermined.

I used a gravity survey to constrain the dimensions and geometry of the basin and surrounding rock bodies at depth. Data processing, modeling, and integration with preexisting data was accomplished using Oasis:Montaj software. The buried basin creates a maximum 
gravity anomaly of approximately $7 \mathrm{mGal}$. Modeling of the data suggests the basin is generally elongate, SW to NE, and has maximum dimensions of approximately $15 \mathrm{~km}$ wide, $50 \mathrm{~km} \mathrm{long}$, and as much as $2.5 \mathrm{~km}$ deep (basin infill). In cross section, the basin is asymmetrical and wedgeshaped, with a NW margin that dips steeply SE and a SE margin that dips more shallowly NW. The Bertie basin is deepest to the south and was likely hydrogeologically open in that direction. Previous datasets have been derived from analysis of the cores at the North Carolina Geologic Survey and include whole rock geochemical analysis, thin sections, and magnetic susceptibility. Interpretation of the geochemical data suggests the Triassic strata are derived from a continental island arc, and thin section analysis suggests a provenance of recycled orogenic material. The rocks classified as Triassic tend to have lower magnetic susceptibility than the overlying Cretaceous rock. One interpretation of these data is a change in sediment provenance from late-stage Triassic basin infill to the overlying Cretaceous strata.

The Bertie Basin is located in the Southern Segment of the North American rift margin, suggesting that its geometry and stratigraphy should reflect regional trends and exhibit characteristics similar to other southern rift basins. The characteristic geometry of basins in the Southern Segment generally includes narrow to medium size (10 to $25 \mathrm{~km}$ across), faultbounded, half-grabens with no or very subtle growth structures. The Bertie Basin may be part of a series of basins or a sub-basin within a larger basin due to sequential, domino-style faulting during rift migration. Higher extensional rates and faster rift migration within the Coastal Plain province may be related to its reduced dimensions. Burial underneath Coastal Plain strata may also have helped to preserve the Bertie Basin's original geometry and size which allows for improved constraints on initial tectonic conditions and structures, sedimentary deposition, paleoenvironments, and processes related to supercontinent breakup. 

GRAVITY SURVEY OF A BURIED TRIASSIC RIFT BASIN, BERTIE COUNTY, NORTH CAROLINA

\author{
A Thesis \\ Presented to the Faculty of the Department of Geological Sciences \\ East Carolina University \\ In Partial Fulfillment of the Requirements for the Degree \\ M.S. in Geological Sciences
}

by

Cody Shell

May, 2020 
(C) Cody Shell, 2020 
GRAVITY SURVEY OF A BURIED TRIASSIC RIFT BASIN IN BERTIE COUNTY, NORTH CAROLINA

by

Cody Shell

APPROVED BY:

DIRECTOR OF THESIS:

Eric Horsman, $\mathrm{PhD}$

COMMITTEE MEMBER:

Scott Giorgis, $\mathrm{PhD}$

COMMITTEE MEMBER:

Don Neal, $\mathrm{PhD}$

COMMITTEE MEMBER:

Terri Woods, PhD

CHAIR OF THE DEPARTMENT

OF GEOLOGICAL SCIENCES:

Stephen Culver, $\mathrm{PhD}$

DEAN OF THE

GRADUATE SCHOOL:

Paul J. Gemperline, $\mathrm{PhD}$ 


\section{ACKNOWLEDGEMENTS}

I would like to thank East Carolina University and the Southeast Section of the Geological Society of America for funding of my research, Dr. Sarah Titus from Carleton College who lent me the gravimeter used during my fieldwork, Tyler Anderson who helped me to collect data, and Dr Horsman, my advisor, for all the time and effort he has spent to help both in the field and with my analysis/research. 


\section{Table of Contents}

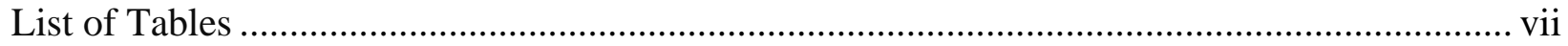

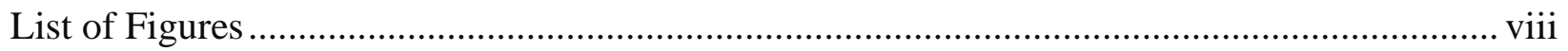

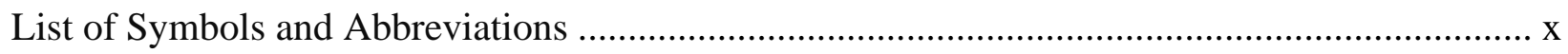

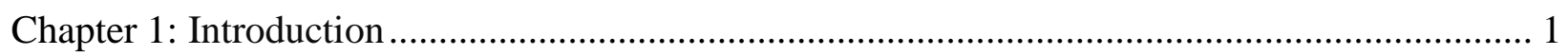

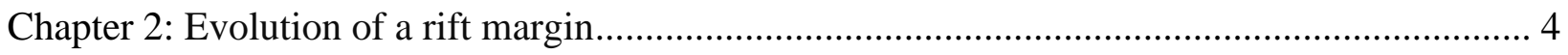

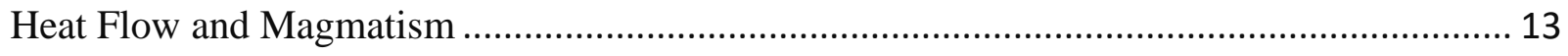

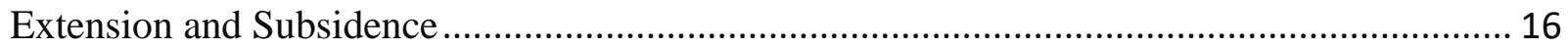

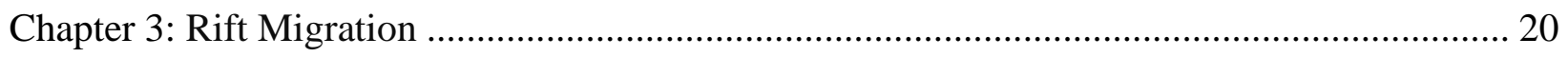

Rift Margin and Basin Geometry ................................................................................. 26

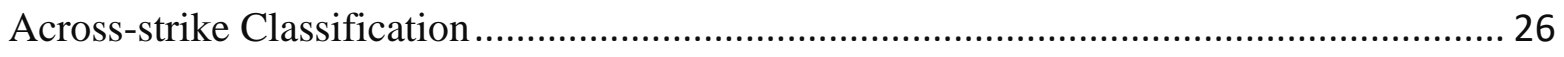

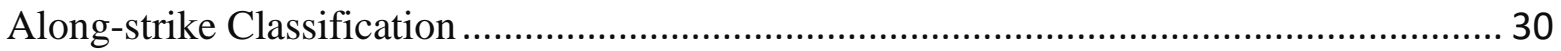

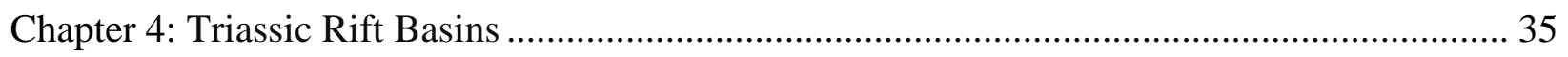

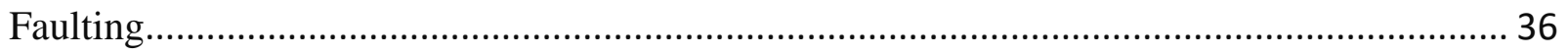

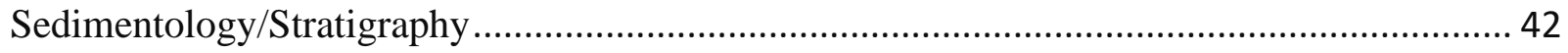

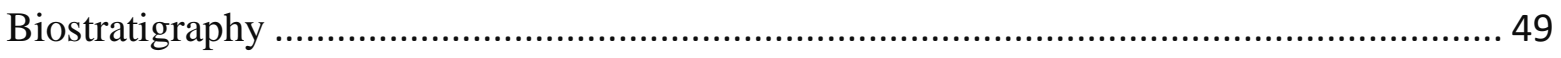

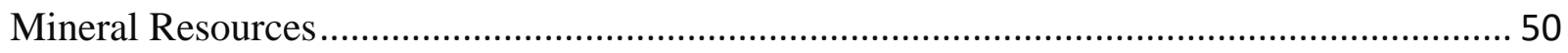

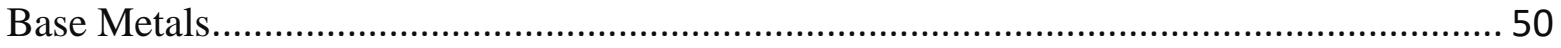

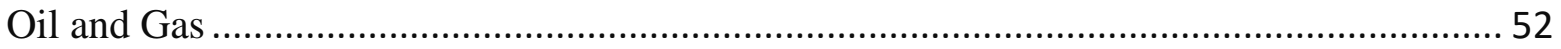

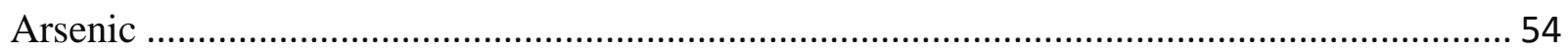

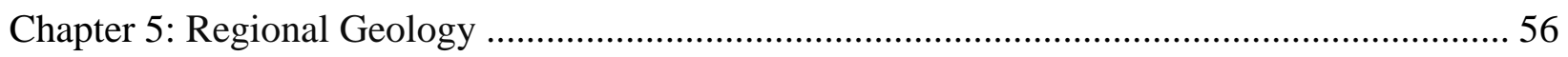

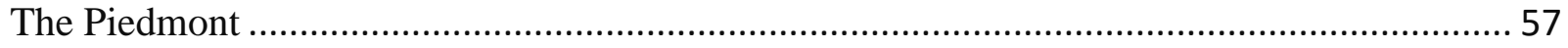

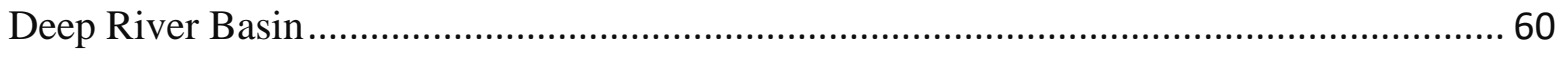

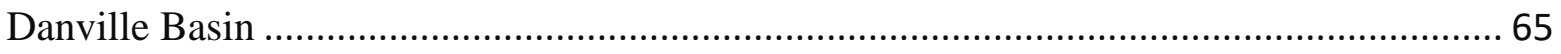

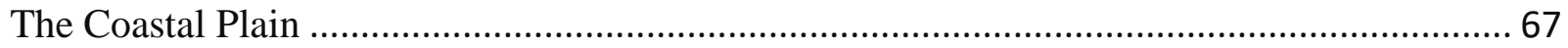




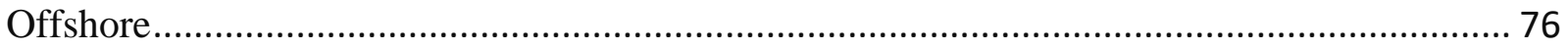

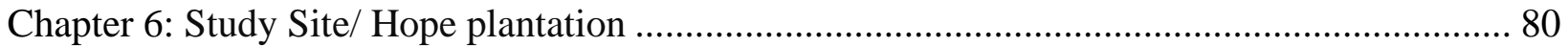

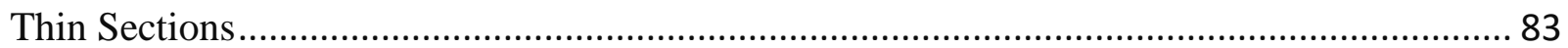

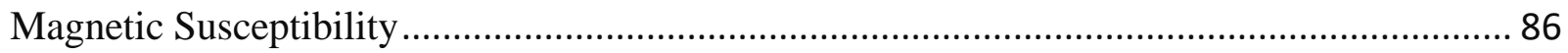

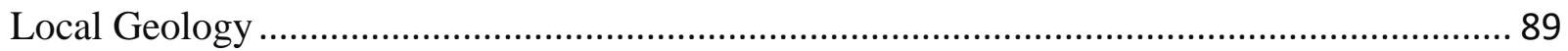

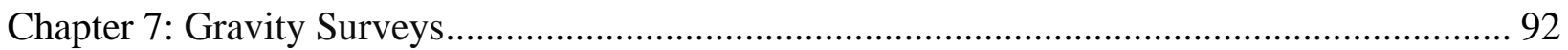

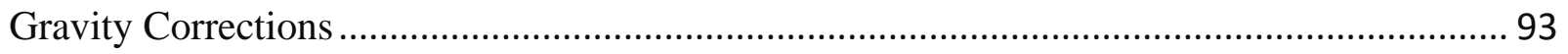

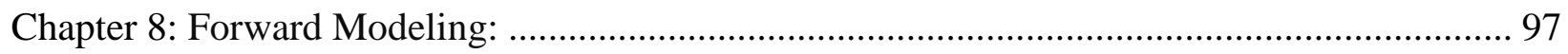

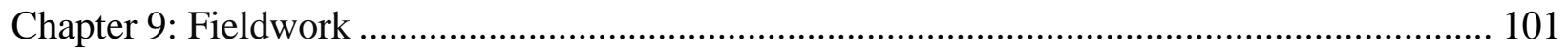

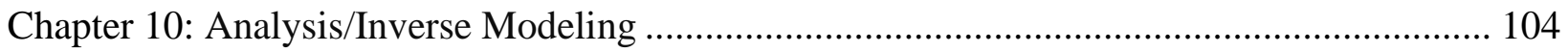

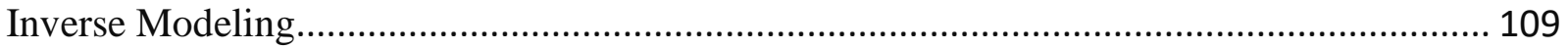

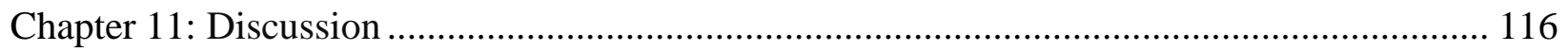

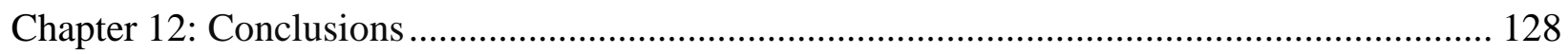

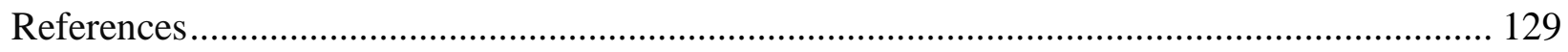

Appendix A: Lithofacies and Depositional Environment............................................. 144

Appendix B: Metal Mines and Occurrences in North Carolina........................................... 148

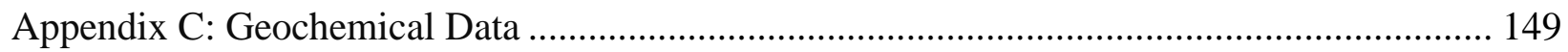

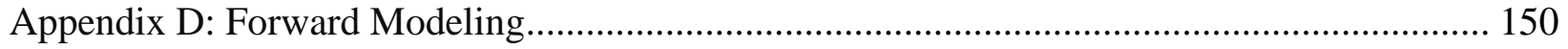

Appendix E: Governing Equations for Correction in Oasis: Montaj..................................... 168 


\section{List of Tables}

Table 1: Maximum gravitational anomaly of basins with varying sizes and burial depths........ 98

Table 2: Maximum gravitational anomaly caused by Triassic strata density and burial depth ... 98

Table 3: Maximum gravitational anomaly caused by densities of overlying sediments ............ 99

Table 4: Absolute gravity values for IGSN71 and local base stations ................................ 102

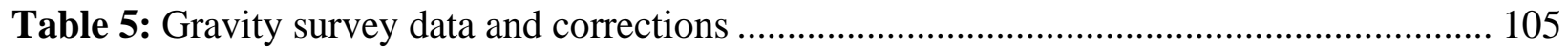




\section{List of Figures}

Figure 1: Location of the studied Triassic basins along the NA Atlantic margin. ..................... 1

Figure 2: Evolution of the continental rift margin during the break-up of Pangaea................... 5

Figure 3: Bathymetric map of the offshore of North Carolina and the Carolina Trough ............. 8

Figure 4: Map of CAMP boundaries and magmatism around early Central Atlantic Ocean ....... 9

Figure 5: Reconstruction of early sea-floor spreading ................................................... 11

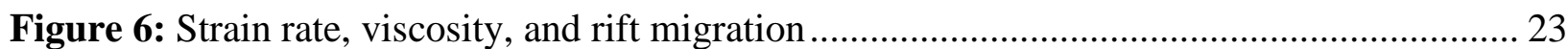

Figure 7: Numerical models of narrow and wide rifts ............................................... 25

Figure 8: Schematic section of a typical rifted margin ..................................................... 27

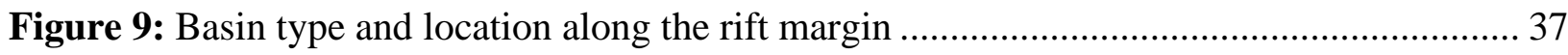

Figure 10: Basin types found in the Southern segment of the North American rift margin........ 38

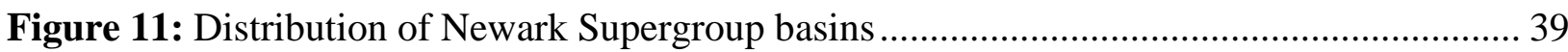

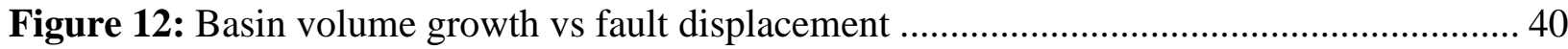

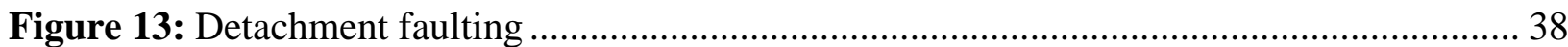

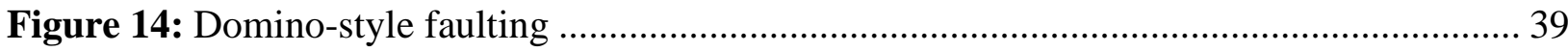

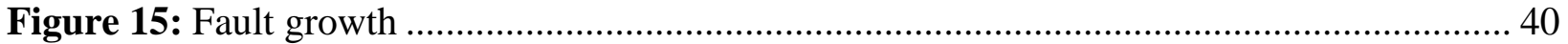

Figure 16: Pattern of basin infill for fault growth model............................................... 42

Figure 17: Schematic of depositional environments common to Newark Supergroup basins .... 46

Figure 18: Kerogen type and hydrocarbon development.................................................. 52

Figure 19: Major geologic regions of North Carolina .................................................... 56

Figure 20: Suprastructural and infrastructural terranes of the Piedmont................................ 58

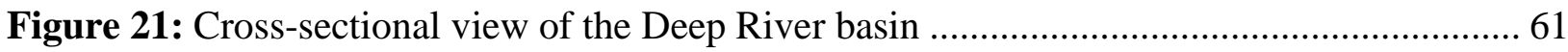

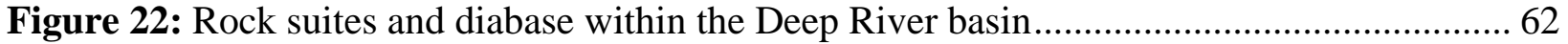


Figure 23: Cross-sectional view of the Danville basin 65

Figure 24: Interpretive geologic map of basement rocks beneath the NC CP....................... 70

Figure 25: Interpretive map of terranes, faults, and metamorphic grade beneath the NC CP.... 71

Figure 26: Cross-sectional view of the Carolina Trough ................................................ 78

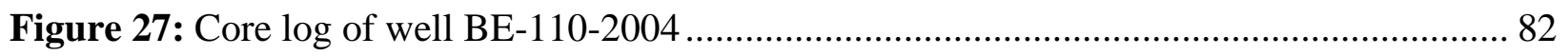

Figure 28: Ternary diagrams of terrigenous sandstones and thin section samples.................. 83

Figure 29: Bar graphs of geochemical tectonic facies and geochemical analysis .................... 85

Figure 30: Graphs of trace element ratios and provenance zones ...................................... 85

Figure 31: Photographs of cores taken from well BE-110-2004 ........................................ 87

Figure 32: Magnetic susceptibility of core samples from well BE-110-2004 ....................... 88

Figure 33: Bouguer anomaly contour map centered Bertie County, NC............................... 90

Figure 34: Location of the study site, Bertie County, North Carolina.................................... 91

Figure 35: Forward modeling of crustal blocks with differing densities.............................. 99

Figure 36: Station locations from gravity survey and PACES database ............................. 103

Figure 37: Complete Bouguer contour map of study site and surrounding areas................... 110

Figure 38: Cross-sectional view and gravity anomaly for transect $A$ to $A$ ' ......................... 112

Figure 39: Cross-sectional view and gravity anomaly for transect $\mathrm{B}$ to $\mathrm{B}$ '........................... 113

Figure 40: Cross-sectional view and gravity anomaly for transect $\mathrm{C}$ to $\mathrm{C}$ '.......................... 113

Figure 41: Side-by-side of complete Bouguer Map and L\&H geologic map........................ 113 


\section{List of Symbols and Abbreviations}

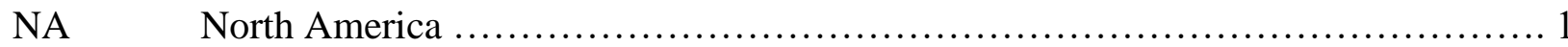

CAMP Central Atlantic Magmatic Province .......................................... 6

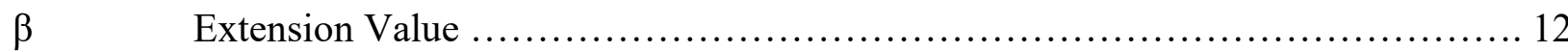

SDR Seaward Dipping Reflector ......................................... 14

COB Continent-Ocean Boundary .............................................. 15

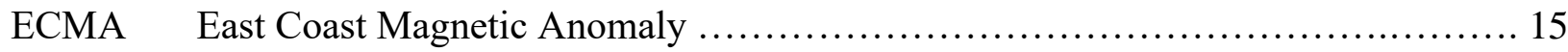

BSMA Blake Spur Magnetic Anomaly ........................................... 16

MOHO Mohorovicic Discontinuity ......................................... 17

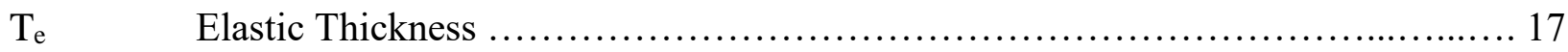

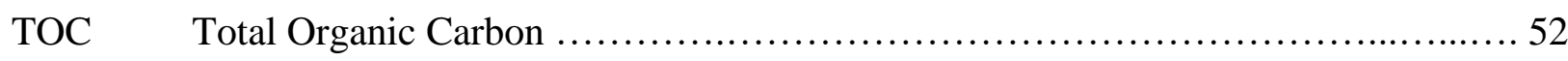

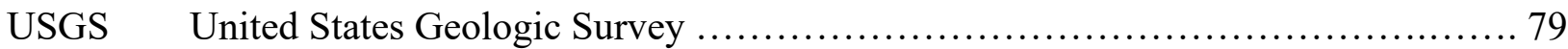

NCGS North Carolina Geologic Survey .............................................. 79

WRD Raleigh Water Resources Discipline ..................................... 79

PACES Pan-American Center for Earth and Environmental Studies ...................... 86

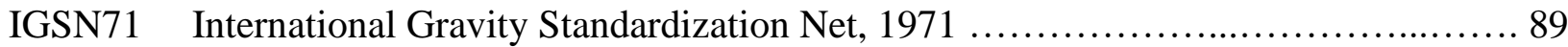

GRS67 Geodetic Reference System Formula of 1967 ................................ 90

DEM Digital Elevation Map ............................................. 100 


\section{Chapter 1: Introduction}

The North American (NA) rift margin includes a series of Triassic rift basins along the eastern United States seaboard, many of which host significant mineral and petroleum reserves (Figure 1). Most of the known basins are exposed at the surface and relatively easy to access, but additional inaccessible basins obscured beneath Cenozoic coastal plain strata have been detected. Subsurface features and basement rock hidden below Coastal Plain strata must be inferred from geophysical data (e.g. aeromagnetic, gravity, seismic refraction, and seismic reflection surveys) and well reports. Much of the Coastal Plain remains devoid of deep well data leaving broad swaths of basement rock and potential rift features relatively undiscovered. In

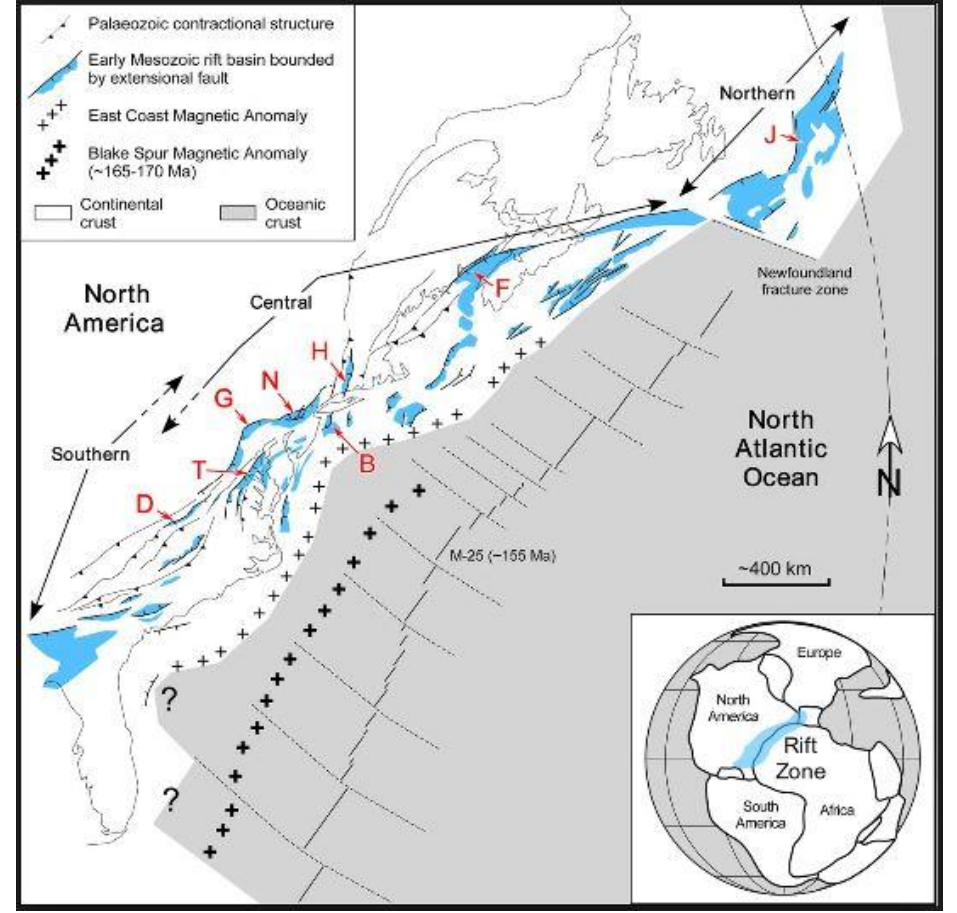

Figure 1: Location of the studied Triassic basins along the North American rift margin. Mesozoic rift basins are D, Danville basin; T, Taylorsville basin; G, Gettysburg basin; N, Newark basin; H, Hartford basin; B, Baltimore Canyon trough; F, Fundy Basin; and J, Jeanne d'Arc. Southern, Central, and Northern segments indicate basins with similar characteristics and basin types (Withjack et al., 2012)

North Carolina, more than 75 wells that recovered samples of phyllite, schist, gneiss, granite, diorite, etc. from beneath Coastal Plain sediments (Daniels and Leo, 1985; Daniels and Zietz, 1978) help define the distribution and depth of "crystalline" basement. Lawrence and Hoffman (1993) used cuttings and cores from 124 boreholes to basement, combined with Bouguer gravity and magnetic maps, to construct an interpretive geologic map, a structure contour map of the basement surface, and a map of metamorphic grade, thereby constraining the extent of sub- 
surface Mesozoic basins. Several rift basins underlying North Carolina's Coastal Plain have been inferred based on geophysical data, including reports by Bonini and Woollard (1960), Behrendt and Klitgord (1979), Chowns and Williams (1983), and Hutchinson and others (1983), but have not been confirmed by drilling.

A buried, recently discovered Triassic rift basin has been identified in Bertie County, North Carolina. The deep core sample documented Triassic age sedimentary rocks buried underneath approximately 300 meters of Cretaceous and younger sediments and sedimentary rock (Weems et al., 2007). This test hole was continuously cored to a total depth of $1094.5 \mathrm{ft}$. The test hole encountered six aquifers: The Surficial, Yorktown, Black Creek, Cape Fear and two deeper aquifers before reaching Triassic strata at a depth of $1026.0 \mathrm{ft}$ (Weems et al., 2007). Crystalline basement rock was not reached leaving the overall thickness of the basin undetermined.

Samples from this core have been investigated using thin sections, geochemistry, and magnetic susceptibility (Abstract: Poythress and Horsman, 2013), but more context regarding basin size, structure, and geometry is required to relate it to other local features and the larger continental rift margin. This thesis describes results of a gravity survey conducted in order to constrain the density, dimensions, and geometry of the Bertie County basin and surrounding rock bodies.

A two-stage gravity survey extended over an area of roughly $1000 \mathrm{~km}^{2}$ was conducted to measure spatial variations in gravitational acceleration. Data gathered from the gravity survey constrains the surfaces between the Cretaceous and younger Coastal Plain sediment, Triassic basin infill, and the significantly denser crystalline bedrock underneath to reveal the rift basin 
feature. The basement surface is defined as the base of the Upper Mesozoic to Lower Cretaceous sedimentary section, commonly referred to as the post-rift unconformity surface.

The evolution of the NA rift margin and development of Triassic rift basins was dynamically affected by many different physical properties and tectonic-scale geologic processes (e.g. heat flow, extension, subsidence, flexure, igneous intrusions, crustal thicknesses, lower crustal ductility, crustal rheology, faulting, and sedimentation). Despite this, many aspects of the rift margin show surprising similarity due to the presence of first-order controls, heat flux and extension. Triassic rift basins within the margin also demonstrate similarities in basin formation, structure, and geometry because they are fundamentally constrained by the same first-order controls (Leleu et al., 2016). 


\section{Chapter 2: Evolution of a rift margin}

Plate tectonics shape the evolution of the continents and oceans via the Wilson cycle, in which supercontinents rift apart to form new oceans that may later close to form a new supercontinent (Stein et al, 2018). The most recent supercontinent, Pangea, began to form approximately $450 \mathrm{Ma}$ as Gondwana sutured with the Euramerica plate. This consolidation resulted in three distinct orogens: The Alleghenian orogen in eastern North America and northwestern Africa, the Variscan orogen in central Europe, and the Ural orogen in west-central Asia (Condie, 2016). Approximately 230 Ma, during the Mid- to Late- Triassic, Pangea began to split apart, triggering crustal thinning and rifting generally along the suture zone of Gondwana and Euramerica (Figure 2). Rifting continued until seafloor spreading initiated along the NA rift margin, beginning as early as $190 \mathrm{Ma}$ (Sahabi et al., 2004), marking the creation of a passive margin with the opening of the Atlantic Ocean.

The Alleghenian orogeny, in the Mid-to Late- Paleozoic, was the most recent of several orogenies that attributed to and influenced the pre-rift structural framework of eastern NA in terms of faulting, compositional heterogeneities, thermal anomalies, associated suture zones, and previous accretionary events (Peron-Pinvidic et al., 2013). This inherited framework influenced later rifting along the same margin due to the reactivation and inversion of these structural features (e.g. faults) during supercontinent breakup. The dependence of rifting on these preexisting structures influenced regional trends in deformation and fault-bounded geometries of the NA rift margin (Leleu et al., 2016). Although Triassic rift basins appear to be tectonically related to reactivation of Paleozoic structures, it cannot be determined whether the border faults follow 
mylonite zones, brittle faults, foliation, intrusive contacts, or some other inherited zone of weakness. (Hutchinson and Klitgord, 1985).

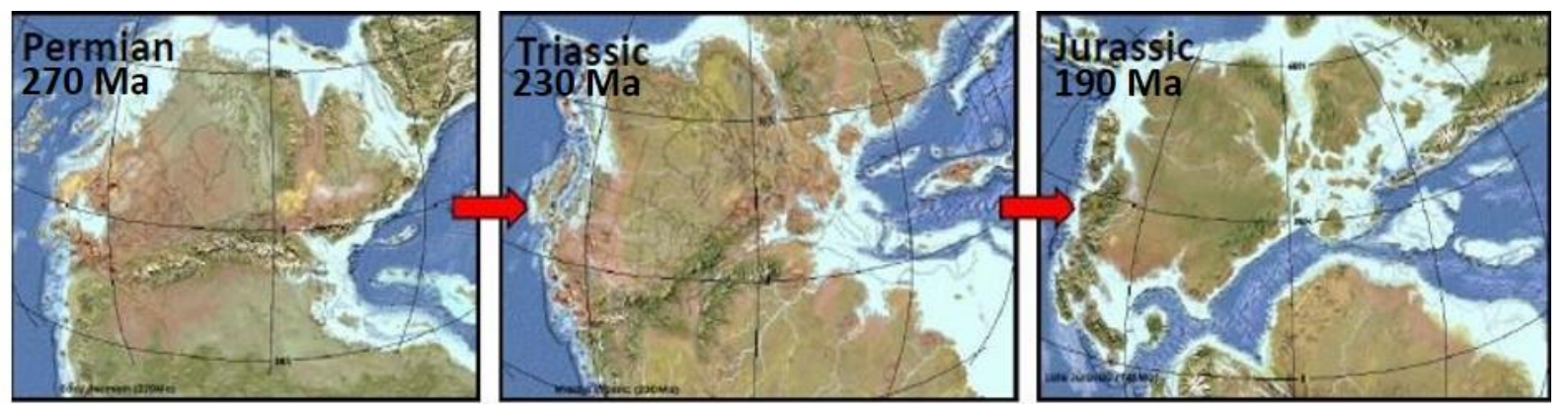

Figure 2: Evolution of the continental rift margin during the break-up of Pangaea. The Permian is pre-rift circa 270 Ma. Triassic rifting began approximately $230 \mathrm{Ma}$ and continued until seafloor spreading began in the Jurassic approximately 190 Ma. (Blakey Maps)

The NA rift margin may have begun to develop as early as the Late Permian or Early Triassic, but little evidence has been found to support those ages. Ductile crustal extension and thinning in mid-crustal layers during that time would not have affected uncoupled, upper crustal brittle deformation. Early episodes of extension and subsidence along the rift margin may have occurred as the consequence of a regional buildup of stress due to mantle uplift caused by a high heat-flow region within the lower crust and mantle resulting in localized and randomly distributed brittle deformation in the upper crust (Leleu et al., 2016). Crustal extension is measured using the parameter $\beta$, the ratio of the initial crustal thickness to the final crustal thickness. For low $\beta$ value of approximately 1 , any strain throughout a region can be accommodated by a distributed fault zone in the upper crust with little to no subsidence. Mesozoic rift basins did not form until large master faults developed during the Middle Triassic, eliminating any potential for basin infill or preservation of sediments from earlier on.

As extension continued throughout the Middle- to Late- Triassic, the active portion of the rift margin migrated both spatially and temporally, and is linked to the development of several 
distinct structural domains across-strike to the margin. The first stage of rift migration resulted in the widely distributed fault zone in the brittle upper crust that coalesced into a series of master faults that planed out at some depth in the upper crust, stepped down into mid-crustal layers, or became deeply rooted in suture zones. Along these master faults, continental Triassic basins developed sub-parallel to the inherited structural framework as is demonstrated by the Danville and Deep River Triassic basins. The Appalachian gravity gradient, a gravitational feature thought to represent a major crustal transition and/or decollement zone between fault blocks, likely represents one such master fault that can be traced underneath the Piedmont Province in the Carolinas (Longwell, 1943, Guo et al., 2019). Crustal thinning on the southeast side of 7 to 10 $\mathrm{km}$ is inferred, a $\beta$ value of approximately 1.1, to cause the gradient between positive and negative gravity values (Cook and Oliver, 1981; Hutchinson and others, 1983). Today, sinuous elongate rift basins along the NA rift margin trend northeast to southwest reflecting the trend of the Appalachian gravity gradient. A $\beta$ value between 1 and 4 is typical of intracontinental sedimentary rift basins which have not subsequently developed into oceanic basins.

Continued extension, beyond a $\beta$ value of around 4 , begins to cause significant subsidence in lithospheric crust and relates to the seaward dipping Coastal Plain basement rock. In this second stage of development, increased extensional rates and rift center migration likely ceased the development of large, deep Triassic basins and led to domino-style faulting and series of smaller adjacent rift basins throughout the Coastal Plain.

A $\beta$ value of 5 is roughly the point at which stretched continental crust breaks and transitions to fully igneous oceanic crust. This represents the main phase of rifting that began in the Late Triassic along the Central Segment of the North American rift margin, the area between modern day Virginia and Nova Scotia/Newfoundland. The free-air gravity anomaly, or "edge 
effect", at rifted continental margins is commonly attributed to transitional crust at the continentocean boundary (COB). In Airy models using isostatic calculations, an anomaly with gravity highs exists over thick continental crust that is flanked by gravitational lows representing thin extended continental lithosphere that transitions into oceanic crust. This high-low couple is a distinctive feature of many rifted margins that generally extends uninterrupted along their strike. A major feature of the NA rift margin is the East Coast gravitational anomaly (ECGA) that occurs along its entire length. This anomaly is related to the "hinge zone" characterized by a basement flexure with slightly extended crust landward and basement rock that dips steeply oceanward transitioning into oceanic crust. This stage of rift margin development is characterized by the convergence of steeply dipping upper crustal basement rock and the Moho. Oceanward of the ECGA, lithospheric crust becomes hyperextended with thicknesses of less than $10 \mathrm{~km}$. Deformation between upper brittle crust and ductile mid-crust becomes coupled in this domain allowing for faults and upper mantle magmatism to traverse the entire lithospheric block.

A second major feature outlining the NA Atlantic rift margin is the East Coast Magnetic Anomaly (ECMA) thought to represent an "edge effect" related to the boundary between transitional crust (i.e. strongly affected by rifting), the basaltic wedge that formed along the margin, and oceanic crust (Hutchinson et al., 1983). Furthest offshore is the Blake Spur Magnetic Anomaly (BSMA), which parallels the ECMA and is thought to represent the landward extent of fully oceanic crust (Figure 3). 


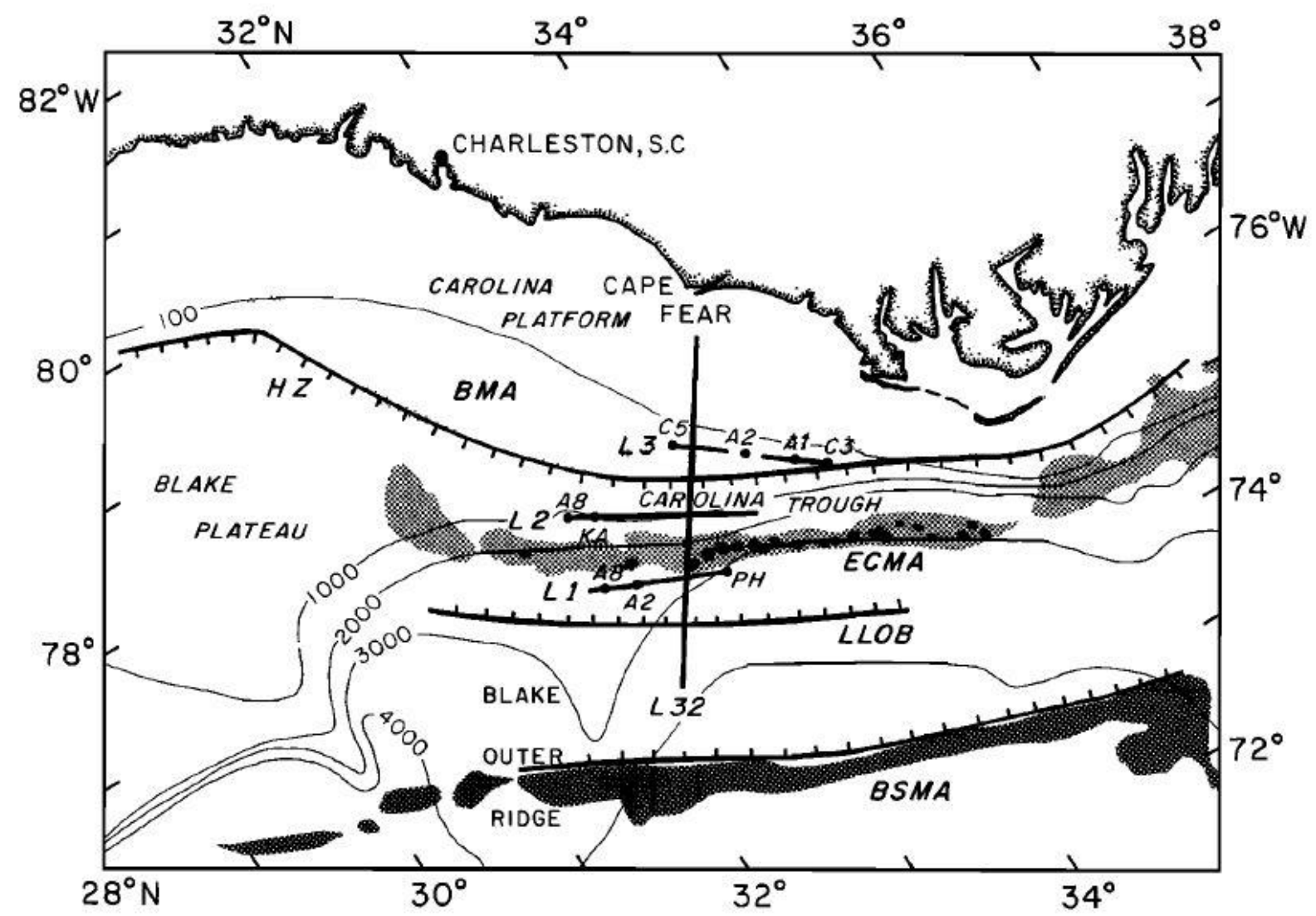

Figure 3: Bathymetric map of the hinge zone, Carolina Trough, and magnetic lineaments produced by rifting and seafloor spreading offshore of the Carolinas. The Blake Spur Magnetic Anomaly (BSMA), the landward limit of well-defined oceanic basement (LLOB), the East Coast Magnetic Anomaly (ECMA), the hinge zone (HZ), the Brunswick Magnetic Anomaly (BMA), and the locations of salt diapirs (solid circles) are shown. (Trehu et al., 1989)

Approximately $200 \mathrm{Ma}$, near the Triassic/Jurassic boundary, lithospheric crust began to completely break as it became hyperextended, culminating in massive amounts of intrusive magmatism along the rift margin. The Central Atlantic Magmatic Province (CAMP) is the largest known continental igneous province which produced massive volumes of mafic intrusions (sills, dikes, etc.) and minor volcanism that covered the entire Central Atlantic domain (Figure 4) (McHone, 2000, 2003). The volume of magma flow reached as much as $3 \times 10^{6} \mathrm{~km}^{3}$ covering an area of roughly 11 million $\mathrm{km}^{2}$. Increased lithospheric heat flow during the end of rifting caused by crustal thinning and the CAMP event produced regional uplift and doming, contributing to deformation, segmentation, and subsequent continental breakup (Leleu et al., 
2016). The mechanism behind the formation of this magmatic province is disputed but may be related to a mantle plume (Hill, 1991; Wilson, 1997; Ruiz-Martinez et al, 2012) or upper mantle sources (Martins et al, 2008; Chabou et al, 2010; Callegaro et al, 2013).

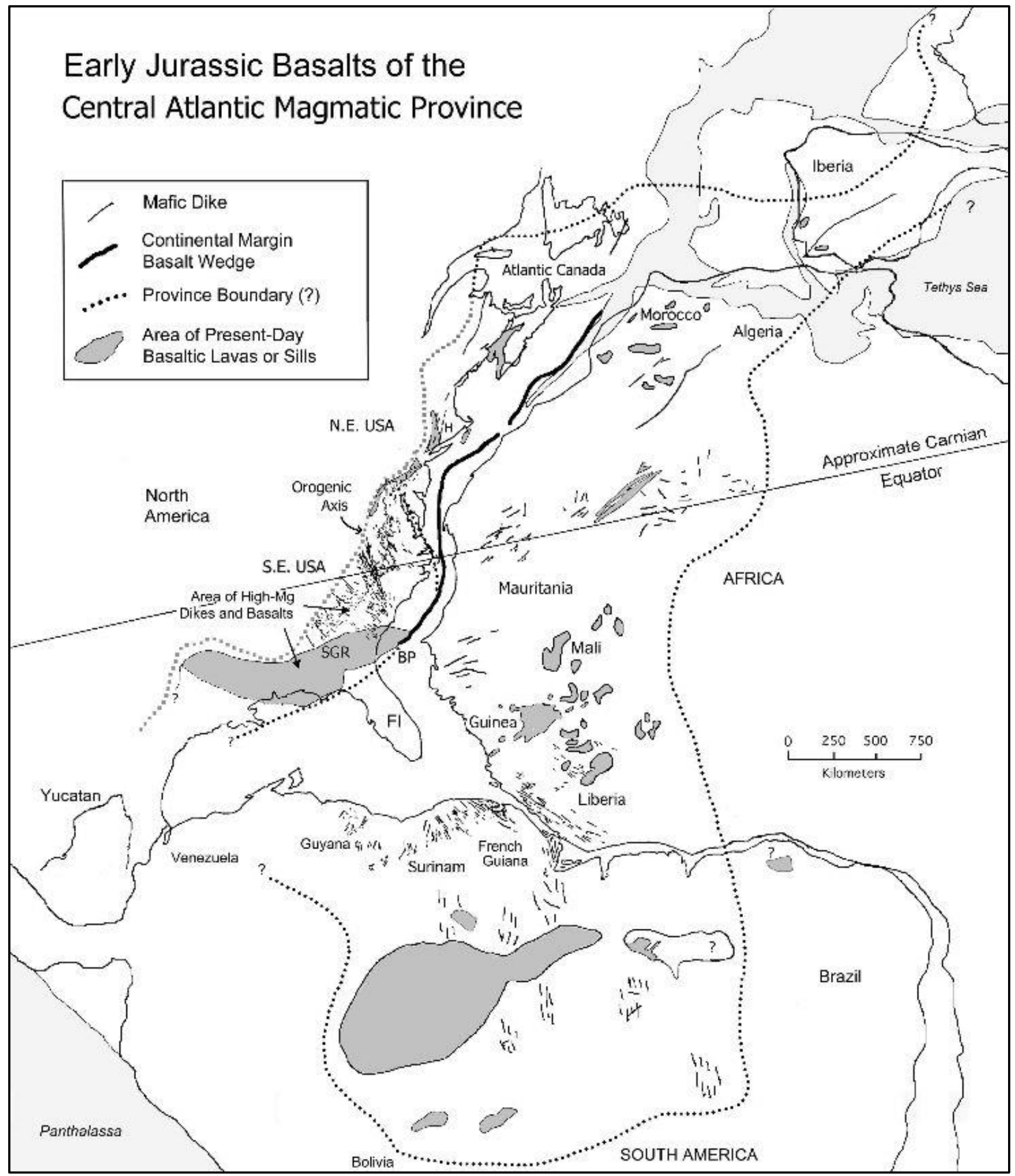

Figure 4: Map of CAMP boundaries and magmatism around early Central Atlantic Ocean. www.auburn.edu/academic/science_math/res_area/geology/camp/MapsFigures 
The eastern NA rift margin is also host to volcanic/volcaniclastic wedges (Schlische et al., 2002). In segments along the rift margin, volcaniclastic wedges (seaward dipping reflectors, SDR's) can be found between the ECMA and BSMA hinting at regions that may have been affected more greatly by magmatism, volcanism, and/or extension (Klitgord et al., 1988). Precise age dating, however, calls into question the relationship between volcanism and continental breakup (Coutillot and Renne, 2003). Along-strike segmentations of gravitational anomalies, +/30 mGal (Hutchinson et al., 1996), make up a series of depressions and platforms within the inner and middle continental shelf regions, and imply that weak lithospheric regions abut strong ones, and are referred to as embayments and arches (Brown et al., 1972). These features likely resulted from lithospheric changes in composition, variable extension rates influenced by igneous intrusions, diachronous seafloor spreading, and post-rift flexure from sediment loading. Unconformable Jurassic age and younger post-rift sediments vary in conjunction with this isostatic segmentation such that depressions have thick accumulation of sediments separated by platforms with thinner accumulations (Schlee, 1981).

A $\beta$ value of 50 is representative of the upwelling which occurs beneath oceanic spreading centers (Anderson, 1994). The opening of the Central Atlantic Ocean between North America and northwest Africa is well documented and believed to have begun in the Early Jurassic, most estimates place it around 185 Ma. The initial fit and timing of seafloor spreading after the initial breakup of Pangaea is still poorly understood, however, due to asymmetry in the amount of oceanic accretion (marginal widths) that developed amid the conjugate margins and the possibility of diachronous seafloor spreading rates. The margin along the North American plate is significantly wider between the ECMA and the BSMA, the earliest oceanic crust, than the corresponding conjugate margin width off Africa's coast indicating different marginal 
evolutions. Previous hypotheses have interpreted the BSMA as the limit of an initial basin prior to one or multiple ridge jumps of the oceanic spreading center leaving older crust on the North American side, circa $170 \mathrm{Ma}$, that occurred in conjunction with a drastic change in the relative plate motion direction and spreading rate. A second phase of extension associated with this period, oriented differently from the Late Triassic extension, produced sets of north-south and northwest-southeast striking faults and dikes, the extrusion of basalt flows, and the intrusion of diabase sheets in many of the basins throughout the rift province, including the Durham subbasin of the Deep River basin (Olsen et al., 1991).

Labails and others (2010) have presented a new model based on analysis of recent geophysical data, identification of the African conjugate to the ECMA, and salt diapirs off Morocco and Nova Scotia that suggests sea-floor spreading began during the Late Sinemurian (190 Ma) (Sahabi et al., 2004) and excludes the need for any ridge jumps to have occurred (Figure 5). Their kinematic reconstruction describes four distinct phases of different spreading rates and infer asymmetries between margins are likely related to the thermal anomaly associated with the CAMP event and its preferential location underneath the African plate.

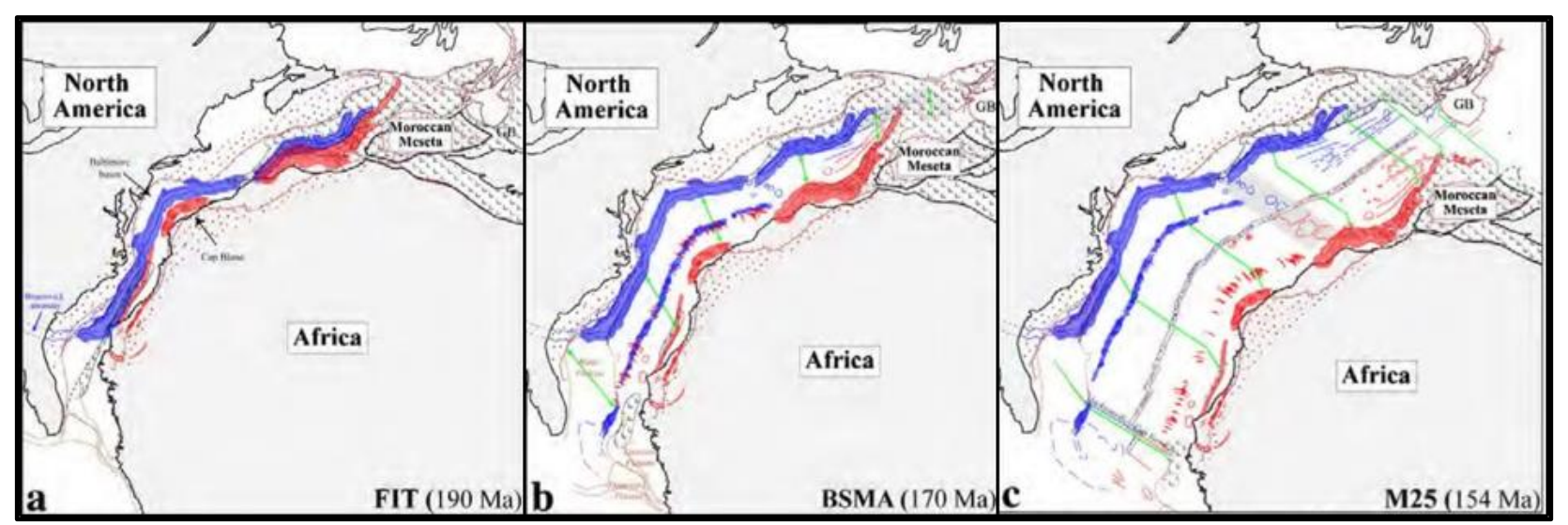

Figure 5: Reconstruction of early seafloor spreading showing conjugate margins with asymmetric widths. Blue indicates the NA margin, red indicates the African margin, and green shows paths from the spreading center. (modified from Labails et al., 2010) 
Throughout the evolution of the NA rift margin, Triassic subsidence of hanging walls of major normal faults and simultaneous uplift of footwalls produce half-graben geometries within rift basins filled by continental fluvial and lacustrine sediments. Syn-rift deposition is found onshore in narrow fault-bounded half-grabens (e.g. Danville and Deep River basins) (Manspeizer, 1985). The half-grabens contain upwards of $5 \mathrm{~km}$ of fanglomerates, flood plain, and lacustrine deposits of Late Triassic to Early Jurassic age. Sedimentation may have ceased near the Triassic-Jurassic boundary with subsequent erosion of syn-rift basin sediments recognized by an unconformity found in many NA Triassic basins (Olsen et al., 1991). After seafloor spreading began, Middle Jurassic production of oceanic crust began with thermally driven uplift and subsequent erosion of exposed basins, followed by cooling-induced subsidence and burial of basins below the Atlantic Coastal Plain onlap (Olsen et al, 1991).

Syn-rift sedimentation is more difficult to recognize underneath the Coastal Plain and offshore where basins are unconformably overlain by thick post-rift sedimentation, the bulk of which is believed to be of Jurassic age or younger (Hutchinson et al.,1986; Wyers and Watts, 2006). In North Carolina, seismic surveys have identified numerous basins and reveal both synrift and post-rift sedimentary sequences (Grow 1981; Hutchinson et al., 1982; Benson, 1984). Manspeizer and Cousminer (1988) indicate the possibility of an early Mesozoic rift basin at Cape Hatteras, as well as one just offshore of the Albemarle sound. Klitgord and others (1988) interpret a Triassic rift basin at a depth of approximately 10,000 ft on U.S. Geological Survey seismic line 32 just offshore of Cape Hatteras and interpret the 800 feet of sandstone above basement in well DR-OT-1-46 as Mesozoic basin infill. Assignment of these sequences to Triassic rift basin sedimentation remains speculative, however. 


\section{Heat Flow and Magmatism}

Rifting in the Middle- to Late- Triassic was triggered by lithospheric extension and changing heat flow conditions in the upper mantle and lower crust. The production of magmarich or magma-poor rifted margins, development of diabase sheets, and the effusion of flood basalts onto the adjacent continents can be explained by a simple model of rifting above a thermal anomaly in the underlying mantle (White and McKenzie, 1989). The initial perturbation of the heat field, or thermal anomaly, began by either a mantle plume rising from the core-mantle boundary or the thermodynamic properties of a supercontinent which prevents subduction and mantle cooling while also insulating interior mantle material. Further, global plate reorganizations which can relatively quickly change stress, heat, and boundary conditions (Anderson, 1994) conceal whether active mantle plumes or supercontinent "insulation" is the main thermodynamic mechanism responsible for rifting. Although the debate continues over what the source of initial changes in the heat regime is, both theories result in subsequent uplift/subsidence, extension, and rifting.

One hypothesis suggests that mantle plumes are the main cause of extension and rifting at the margin. Models have shown that oceanic lithosphere affected by a mantle plume with temperatures raised $100-200^{\circ} \mathrm{C}$ above normal asthenosphere temperatures typically results in crustal doming over an area as large as $2000 \mathrm{~km}$ in diameter (White and McKenzie, 1989). These relatively small increases in mantle temperature are sufficient to generate huge quantities of melt. An increase of $100^{\circ} \mathrm{C}$ above normal can double the volume of melt while a $200^{\circ} \mathrm{C}$ increase can quadruple it (White and McKenzie, 1989). The mantle melt generated by raised temperatures, doming, and decompression migrates rapidly upward until it is either extruded as basalt flows or intruded into or beneath the crust (White and McKenzie, 1989). Oceanic plateaus and flood 
basalts near to or offshore are considered manifestations of massive mantle melting and rapid melt drainage (Anderson, 1994).

Magma-rich continental rift margins and flood basalt provinces are often related to a thermal anomaly associated with a nearby mantle plume actively upwelling mantle beneath rifting continental lithosphere (White and McKenzie, 1989). This process can explain most of the major rift-related igneous provinces including the opening of the North Atlantic in the presence of the Iceland plume. New continental rifts do not always occur above thermal anomalies caused by plumes, but when they do, large igneous provinces such as the CAMP event intrude and are accreted to the continental crust, an important method of increasing the volume of the continental crust through geologic time (White and McKenzie, 1989).

The opposing hypothesis suggests a supercontinent "insulates" the mantle and isolates it from subduction-related cooling at its outer boundaries, increasing the heat regime under continental lithosphere (Anderson, 1994). Subduction and spreading-induced adiabatic melting affect the motion and buoyancy of the mantle, and pull-apart thick cratonic lithosphere (Anderson, 1994). Over time, the interior of the supercontinent breaks into pieces that move outward toward cold, downwelling mantle where continents tend to congregate (Gurnis and Zhong, 1991). Plate motions on a sphere are intrinsically interrelated and episodic, and rates and directions of plate motion are governed by slab pull, ridge push, and continental drag (Forsyth and Uyeda, 1975; Anderson, 1994). Trench roll-back and ridge-trench collisions may even exacerbate supercontinent breakup and further localize mantle upwellings (Cserepes and Christensen, 1990; Anderson, 1994).

Strong feedback exists between plate motions, locations of continents, and mantle convection (Nataf et al., 1981; Anderson, 1982). Downwellings and upwellings are intimately 
related, and surface conditions and plate position are important for influencing their locations. Lithosphere, once flawed by rifting, remains weak and susceptible to later rifting (Burke and Dewey, 1973). Extensional plate boundaries usually start at pre-existing sutures rather than at the random places predicted by plume theories (Anderson, 1994). Lateral temperature contrasts and magmatism might depend more on lithospheric and upper-mantle conditions and past history (continental insulation, subduction, melt removal, previous rifting) than core-mantle conditions (Anderson, 1994). Plumes are treated as superimposed on, and independent of, plate tectonics and mantle convection (Griffiths and Campbell, 1990; Davies and Richards, 1992; Hill et al., 1992a). In the plume theories, thermal anomaly activity is controlled by local rather than global conditions. The relation between ridges, trenches, and continents is constantly shifting, abruptly changing boundary conditions and stresses, making it difficult to understand sustained magmatic activity and large-scale rifting processes across a supercontinent within the context of a local plume (Anderson, 1994).

Magmatism likely depends on stresses in the plates and the locations and orientations of incipient rifts as well as on mantle conditions (Anderson, 1994). Increases in magmatism and spreading rates can be correlated with both a global plate reorganization (i.e. the breakup of Pangea, continental deformation, and plateau production in other oceans) and mantle plumes (Anderson, 1994). If plate-tectonic forces rather than plumes control the timing and location of large igneous provinces such as the CAMP event, however, then they should be located at lithospheric discontinuities and be related to regional or global reorganizations of plate motions such as supercontinent breakup (Anderson, 1994). 


\section{Extension and Subsidence}

Rapid extension of continental lithosphere produces crustal thinning and upwelling of hot asthenosphere to fill the space. The rate and amount of extension and subsidence during continental break-up is related to heat flow, temperature of the underlying asthenosphere, volume of melt, and initial lithospheric thickness (McKenzie, 1978). Therefore, a knowledge of the crustal thicknesses together with the temperature conditions of thermal anomalies forming under continental lithosphere is required to have a more complete understanding of how rift margins develop. On continental scales, however, regional variation in crustal thicknesses and rheology, temperature conditions, and magmatism complicate our understanding of the NA rift margin's initiation and development.

When continental lithosphere is thinned by extension, the elevation of the surface changes to maintain isostatic equilibrium (McKenzie, 1978). Active rift margins from around the world have all formed on Phanerozoic lithosphere, helping to constrain initial continental crustal thicknesses (Richter and McKenzie, 1981). Crustal thicknesses from 70 to $130 \mathrm{~km}$ for Phanerozoic lithosphere and normal asthenosphere temperatures of $1280^{\circ} \mathrm{C}$ result in subsidence of the Earth's surface (Anderson, 1994). Since stretched continental crust has very little flexural rigidity, the subsidence can be calculated easily, assuming that local isostatic equilibrium is maintained (Barton and Wood, 1984). Stretching by a factor of 5 above normal-temperature asthenosphere produces subsidence of more than $2 \mathrm{~km}$ to maintain isostatic equilibrium. If the underlying asthenosphere mantle is hotter than normal due to a thermal anomaly or mantle plume, a significant reduction in the amount of subsidence occurs (Anderson, 1994). Models show that when the asthenosphere temperature is $100^{\circ} \mathrm{C}$ above normal, the initial subsidence is reduced from 2.3 to $1.5 \mathrm{~km}$, and when the temperature is $200^{\circ} \mathrm{C}$ above normal, it subsides by 
only $0.5 \mathrm{~km}$ (Anderson, 1994). Additionally, the presence of a mantle plume within a rift margin can affect the amount of extension and subsidence through increased magmatism, the addition of igneous material to the crust, the dynamic support caused by the mantle plume itself, and changes in density of the residual mantle after removal of melt (Anderson, 1994). For example, the accretion of melt to the crust can greatly affect the subsidence and can be estimated using the appropriate volume of igneous rock and its density for any given combination of stretching factor and asthenosphere temperature (Anderson, 1994).

The timing of volcanism at the surface depends on the time and rate of lithospheric thinning combined with the time it takes for melt to move upward to the surface (Anderson, 1994). Nearly all melt produced by decompression melting separates from its residue and moves directly upward to be either erupted onto the surface or emplaced in the crust. The basalts that are formed by asthenosphere decompression separate out from the matrix very quickly, and the majority of the melt will reach the surface in less than $1 \mathrm{~m} . \mathrm{y}$. after its formation (McKenzie, 1985). Thinning of the lithosphere by a $\beta$ value of 2 at $1480^{\circ} \mathrm{C}$ produces alkali basalts passing to tholeiitic basalts as the stretching is increased further. Tholeiitic basalts related to the CAMP event are common compositions of igneous intrusions (i.e. dikes) throughout the NA rift margin and are indicative of thermal conditions and extensional values that existed during rifting (Anderson, 1994).

Generally, volcanism is absent from the NA rift margin apart from minor syn-rift volcanism that is associated with the initial stages of Triassic rifting, approximately $230 \mathrm{Ma}$, (Bosworth, 1987), and continental flood basalt flows that erupted during a short period simultaneous with the main rifting and CAMP event, approximately $200 \mathrm{Ma}$. The thickest igneous sections are found on rifted continental margins with a $\beta$ value of approximately 5 , 
where hyper-extended crust breaks completely and transitions to oceanic crust, allowing basalt to flow out laterally, downhill, and seaward generating extensive areas of flood basalts and basalt wedges on the adjacent landmasses (Anderson, 1994).

The presence of large quantities of volcanic rocks with characteristic patterns of seaward dipping reflectors (SDR's) seen on many seismic reflection profiles along the NA rift margin are likely caused by thick basaltic flows (Hinz, 1981). SDR's generally exhibit convex upward curvature with dips that increase in a seaward direction and have often been used as an indication of the continent-ocean boundary (COB) (Anderson, 1994). Also, recognition of SDR's make it relatively easy to map the distribution of volcanism along continental rift margins. Much of the evidence for this, however, is now deeply buried underneath Jurassic, Cretaceous, and Cenozoic sediments of the coastal plain and are only accessible by geophysical surveys.

Seismic refraction data shows that the Moho along the NA rift margin is approximately in the position predicted by an Airy model of isostatic equilibrium (Keen et al., 1975). Crustal segmentation along the margin, however, cannot be explained Airy models. Recent studies suggest that sediment loading and magmatism may have modified the edge effect anomaly, amplifying segmentation along-strike (Karner and Watts, 1982; Wyers and Watts, 2006). A flexure model by Wyers and Watts (2006) considers the possibility that margin lithosphere is of finite strength during rifting and may undergo flexure and displacement of the Moho. By comparing the calculated gravity anomaly associated with rifting and sediment loading to the observed free-air anomaly and combining it with 3-D flexural backstripping, an elastic thickness, $T_{e}$, can be determined for the margin. $T_{e}$ decreases with increased crustal thinning and flexed basement curvature (Wyers and Watts, 2006). The long-term lithospheric strength, by proxy of elastic thickness, could either enhance or limit extension and create an isostatic imbalance that 
results in different crustal structure and segmentation than predicted by an Airy model (Wyers and Watts, 2006).

Wide-angle seismic experiments on rifted continental margins in the North Atlantic have shown that accompanying the extruded basalts that form the SDR's there is an even greater volume of new underplated or intruded igneous rock in the lower crust (White et al., 1987b; Mutter et al., 1988). This underplating arises because as low-density melt rises, high density residue ("restite") ponds at the base of the crust (Vervoort et al., 2007). This high-density material can affect the subsidence of the rift margin, subsequent evolution of the rifted region, and may cause flexure and/or displacement of the Moho.

If the rift margin has passed across, or near a mantle plume, vast quantities of melt generated in the upwelling mantle plume move quickly to the surface and can create a 15- to 30$\mathrm{km}$ thick igneous ridge across the opening ocean (i.e. the outer continental shelf) (Anderson, 1994). The opening of the Atlantic Ocean produced up to 10 million $\mathrm{km}^{3}$ of igneous rock along the rifted margins in as little as 2-3 m.y. (White et al., 1987b). A decrease in excess asthenosphere mantle temperature results from the enormous loss of heat advected out of the mantle by melt. Once a continental margin has ceased rifting and a new oceanic spreading center has developed, the margin will begin to subside thermally in a manner determined by the amount of stretching as the underlying asthenosphere cools (Anderson, 1994). 


\section{Chapter 3: Rift Migration}

Rifting on the continental lithosphere primarily occurs along low-angle faults within a brittle upper crust uncoupled to ductile extension in the middle and lower crust. These low-angle faults may plane out at some depth in the upper crust, step down to a deeper level in the middle crust (Cook and others, 1981; Secor and others, 1986) or become rooted in a steeply dipping suture zone (Iverson and Smithson, 1983). These faults can be planar, such as paired faults often associated with Triassic basins, or listric, such as the decollement zone associated with the Appalachian gravity gradient (Hutchinson and Klitgord, 1988). Simple pure shear models of rifting continental crust can reproduce faulting in the upper crust, rift basin formation and development, and mid- to lower- ductile crustal thinning, but uniform stretching inherent to these models does not allow for large-scale marginal asymmetry representative of the NA and conjugate African/Iberian rift margins.

There has been much debate about the possibility that in extensional regions there may be major listric/detachment faults extending through the crust and possibly through the entire lithosphere which allow the upper crust to thin in one location forming rift basins while transferring the major lithospheric thinning laterally to another region in the middle and lower crust (Bally, 1981; Wernicke, 1985). This idea addresses three issues not accounted for in simple pure shear models of listric faulting. First, the crustal rifting, marginal widths, and subsidence are very different on the two sides of the developing oceanic rift. Second, material can be moved from one side of the margin to the other. For example, the Piedmont and Coastal Plain basement are considered to be a peri-Gondwanan volcanic arc that was shoved onto the NA continent during the formation of Pangaea and left behind after rifting. Third, the magmatism caused by 
decompression of upwelling asthenosphere is often offset laterally from the main region of crustal thinning (Bosworth, 1987). This idea, although structurally coherent with the NA rift margin, remains problematic with regards to crustal rheology and flow law, thermo-mechanical modeling, and final marginal width. Additionally, there are no corroborative geophysical surveys that indicate faulting is extended through the mid-to lower- crust.

Recent thermo-mechanical modelling results present a new hypothetical rift margin evolution in which large-scale asymmetry does not form by slip on large detachment faults crosscutting the crust or entire lithosphere, but by an array of oceanward dipping faults that act sequentially in time. This hypothesis suggests hyper-extended crust and margin asymmetry are produced by steady state rift migration (Brune et al., 2014). The extent of rift migration, final margin width, and asymmetry depend on lower crustal viscosity near the moving rift, which in turn is a function of extension velocity, lower crustal rheology, intensity of strain softening, and initial thermal structure (Brune et al., 2014).

Rift migration is accomplished by sequential, seaward-younging, upper crustal faults, and is balanced through lower crustal flow and extension (Brune et al., 2014). In general, rifting starts with a fault network that distributes deformation across the whole width of the margin before friction softening causes development of a dominant single fault with minor antithetic faults, typical for narrow rift basins (Figure 6). The time necessary for the deformation to localize into this dominant fault is a function of lower crustal rheology, with weaker rheologies showing a prolonged phase of initial distributed faulting (Brune et al., 2017). Upper and midcrustal deformation are decoupled from one another, but at the downward tip of the main normal fault, brittle and ductile deformation in the crust and mantle are strongly linked. Slip along this dominant initial fault results in large amounts of crustal thinning and hot asthenospheric 
upwelling. Concurrently, sub-horizontal ductile shear zones develop in the lower portions of both the upper and mid crust (Brune et al., 2014).

Upwelling of hot mantle material is more pronounced near the down-dip end of the initial dominant fault, so that the $600^{\circ} \mathrm{C}$ isotherm penetrates into the lower crust. Elevated temperature and viscous strain softening generate a pocket of weak lower crust at the fault tip referred to as an "exhumation channel" (Brune et al., 2014). At the footwall side of the exhumation channel where the upwelling mantle is shallowest, cooling and strengthening of mantle material takes place. These two processes: 1) softening at the tip of the active fault and 2) strengthening at its footwall - generate a lateral strength gradient that forces migration of the rift in a steady-state manner.

Crustal thinning in the rift zone is accomplished by short-lived (a few million years) sequential faults with high-slip velocities (i.e. $12 \mathrm{~mm}$ per year slip on the fault plane) accommodated by ductile extension in the lower crust. During migration of the rift center, sequentially active faults form on top of the exhumation channel cutting into undisturbed brittle crust. This permits accretion of crustal material across the migrating plate boundary zone to the opposite rift side. Simultaneously, ductile lower crust within the exhumation channel flows towards the down-dip end of the rift-bounding faults. This flow balances the faults' tendency for crustal thinning and break-up, and it promotes the formation of a single, wide margin on one rift side with crust thinned to a thickness of approximately $10 \mathrm{~km}$ (Brune et al., 2014). Numerical modelling (Figure 6) indicates that higher rift velocities elevate the temperature of the exhumation channel causing increases in the extent of the low-viscosity pocket and generating wider margins with more pronounced asymmetry (Brune et al., 2014). 

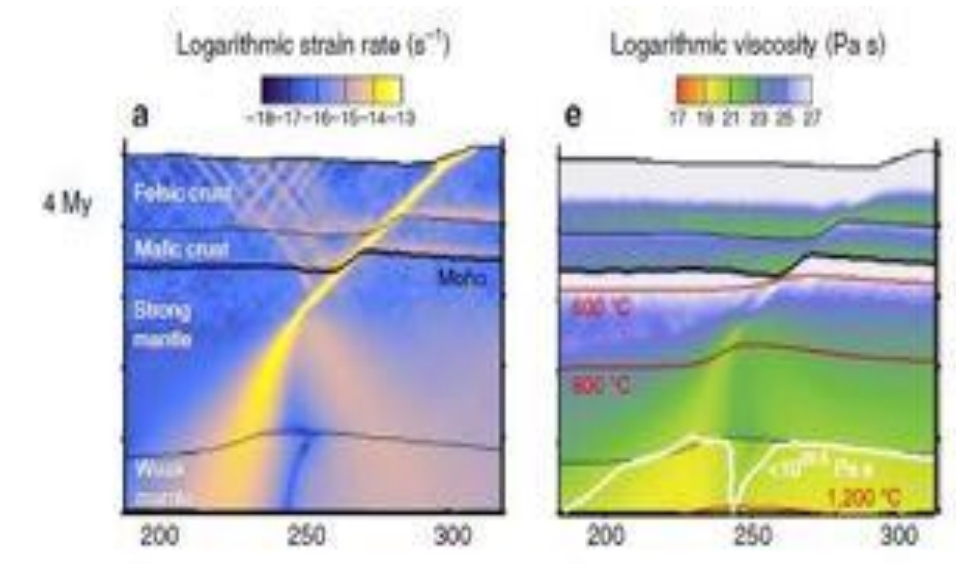

$8 \mathrm{My}$

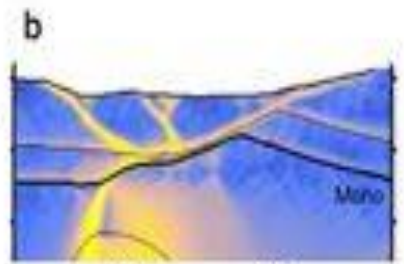

250

300

$16 \mathrm{My}$

c

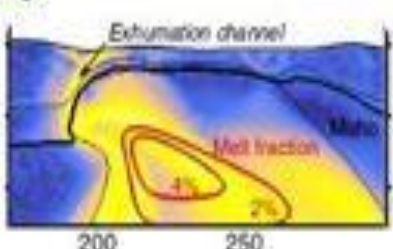

d

$32 \mathrm{My}$

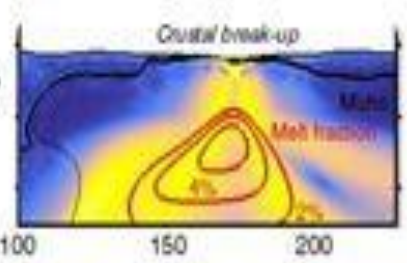

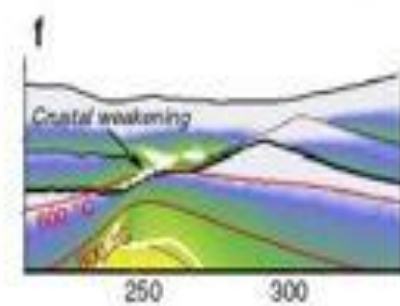

g

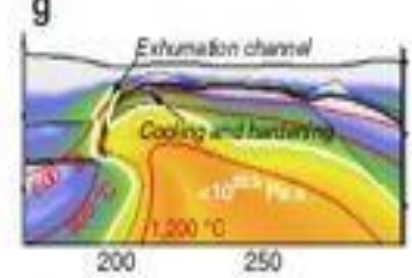

h

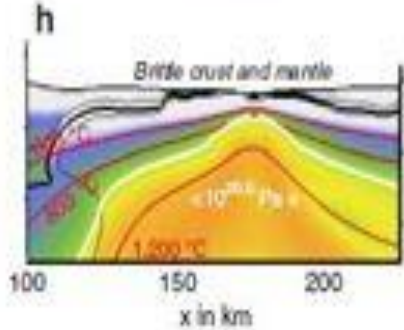

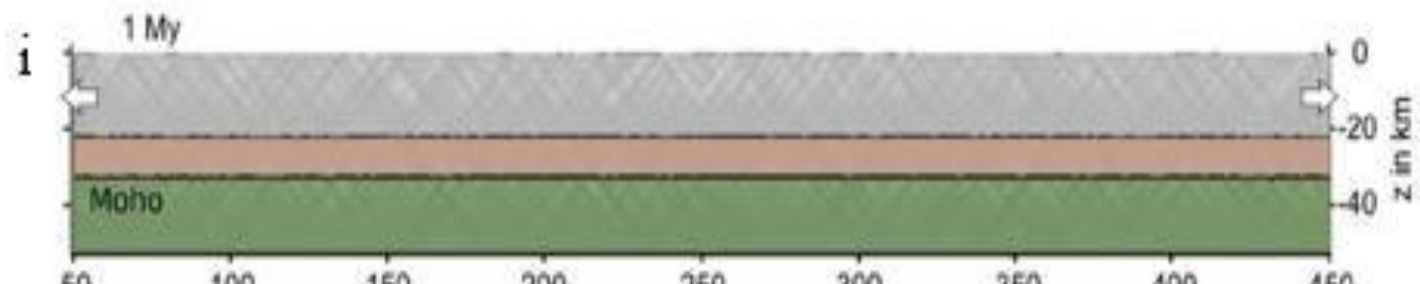

50

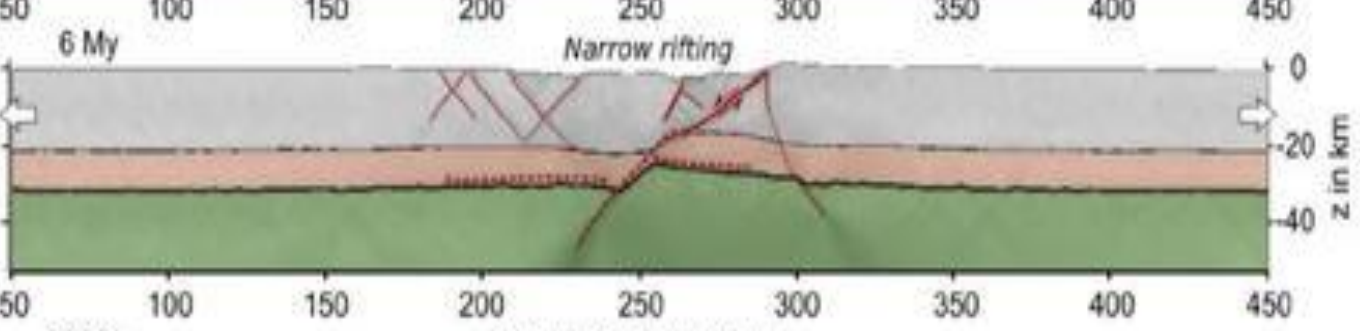

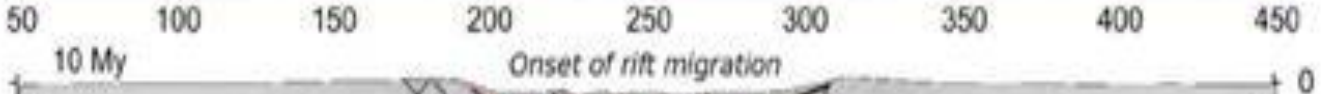
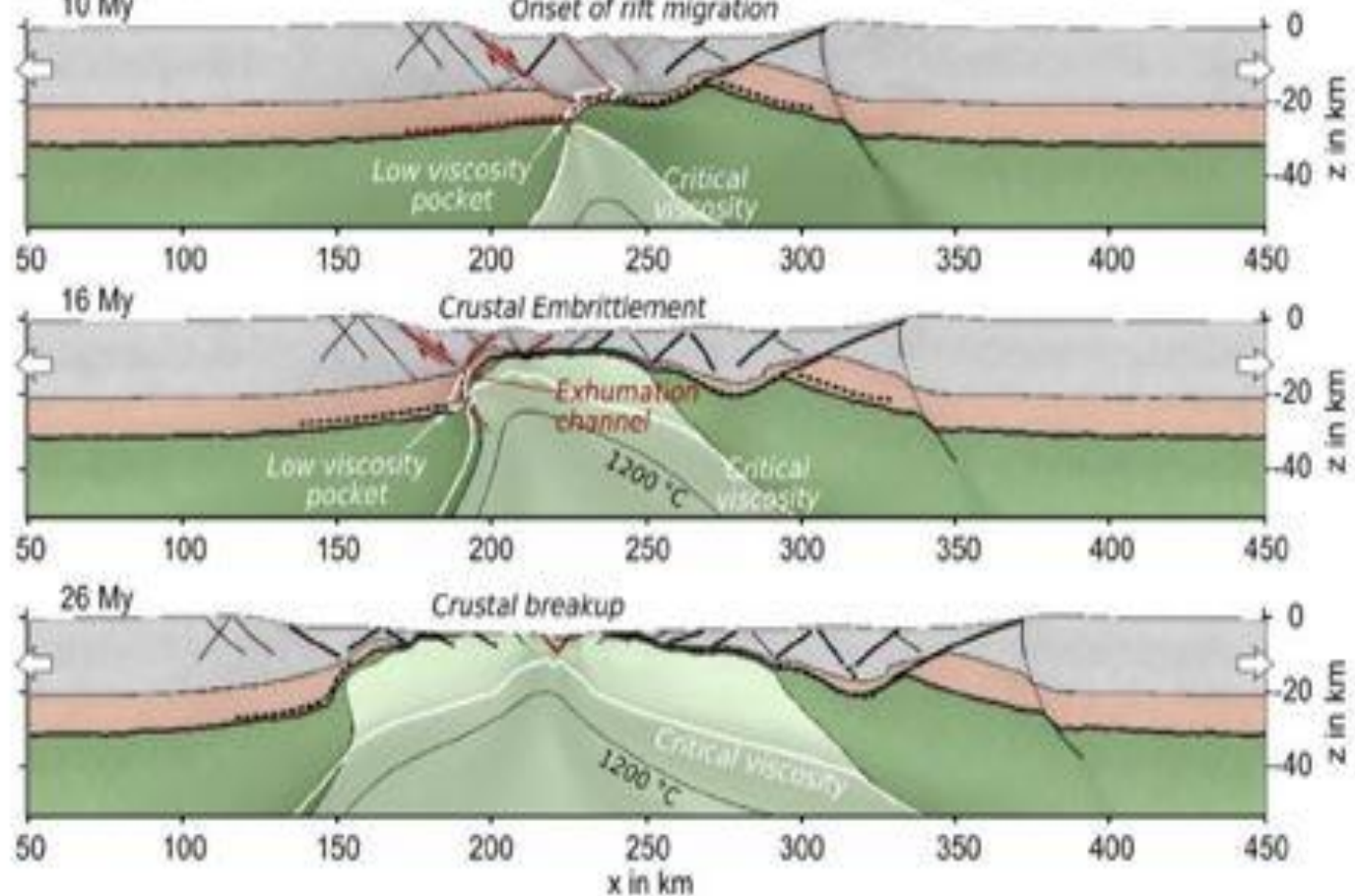

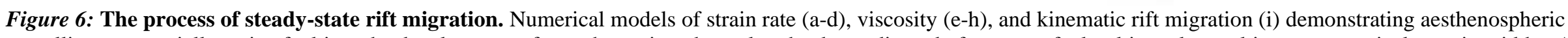

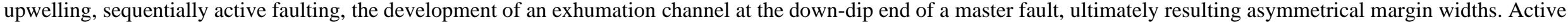
faults are shown in red and inactive faults in black. Brittle faults are indicated with solid lines, ductile shear zones with dotted lines. (Brune et al., 2014) 
Despite extreme final marginal widths (more than $200 \mathrm{~km}$ ) the actively deforming plate boundary zone appears to be very narrow. Moreover, lateral rates of motion of the rift center results in seaward migrating heat flow. With continued rift migration, the steady-state heat supply to the exhumation channel decreases. The crust becomes cooler, and the ductile portions of the crust strengthen to a degree that the low-viscosity pocket vanishes. The crust becomes progressively brittle and faults penetrate from the surface to the mantle in hyper-extended regions. Soon after, these faults bring the crust to break-up until mantle is exhumed with very little magmatic activity and oceanic crustal blocks form amalgamated with continental blocks within a transitional zone. Numerical models demonstrate that both narrow and wide rifts, controlled by crustal rheology, can form highly asymmetric thinning among conjugate margins as is the case with the NA rift margin (Figure 7) (Brune et al., 2017). 
Temperature in ${ }^{\circ} \mathrm{C}$
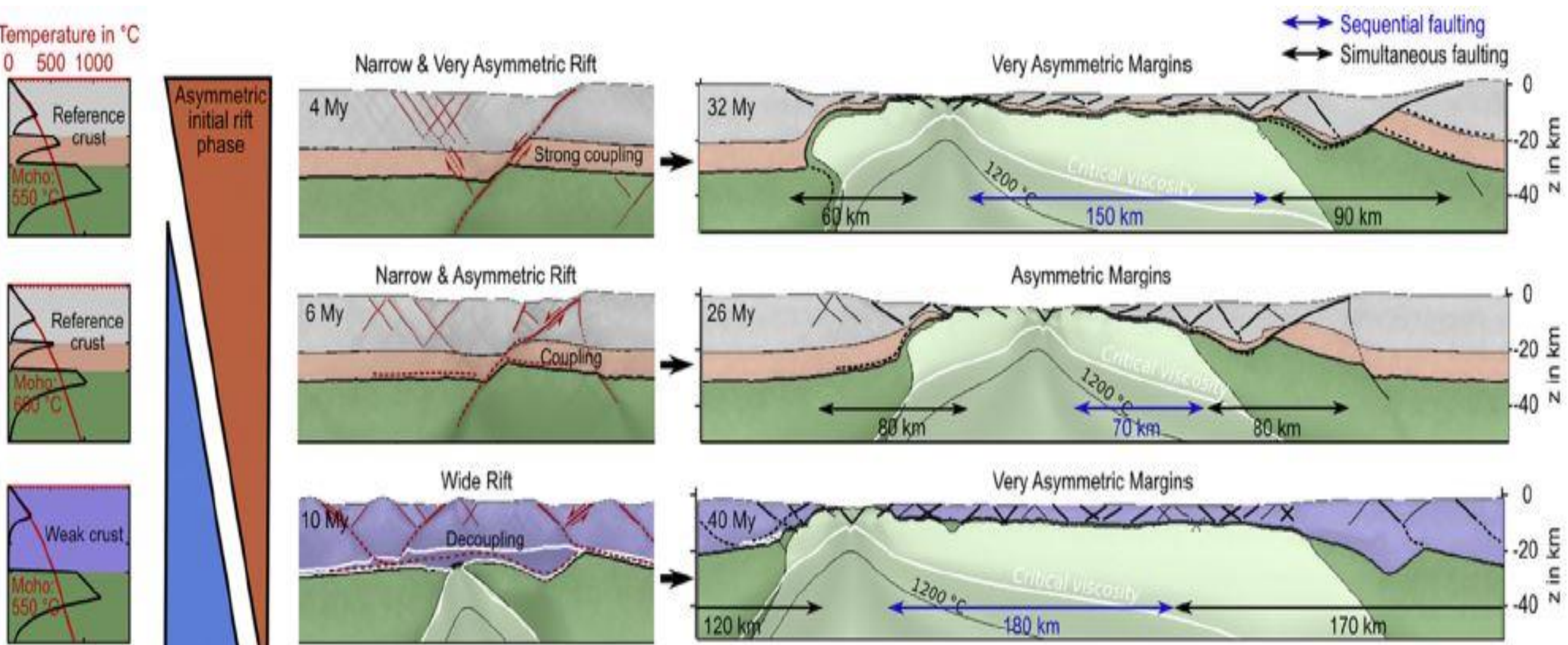

Wide Rift
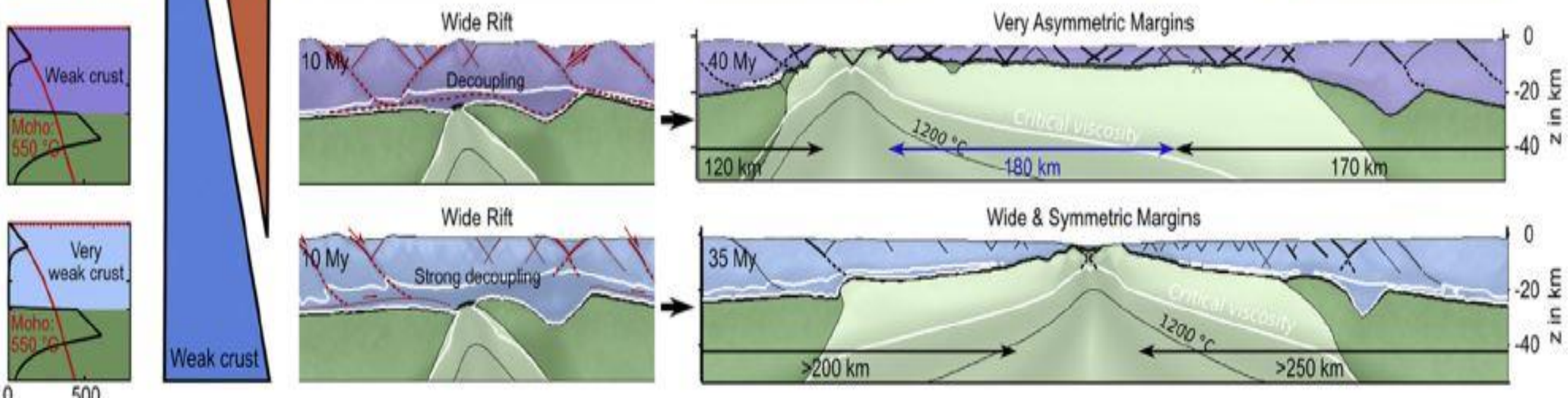

Wide \& Symmetric Margins

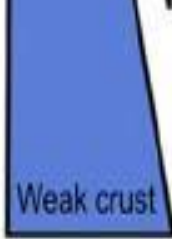

Diff stress in MPa

Figure 7: Numerical models of rift migration influenced by crustal rheology, weak or strong, resulting in narrow and wide rifts of both an asymmetrical/symmetrical nature. Strong crust generates narrow rifts with large initial asymmetry and weak crust favours wide rifts with initially symmetric configurations. Final marginal structures are depicted on the right. The width of the margin that is formed during the simultaneous faulting phase (indicated with black arrows) and al so the total margin width grows proportional to the weakness of the crust. The width of the hyperextended margin (blue arrows) depends on the duration of rift migration. Both narrow and wide rifts are capable of forming highly asymmetrical conjugate margins. (Brune et al., 2017) 


\section{Rift Margin and Basin Geometry}

Triassic basins along the North American Atlantic margin can be generalized into regions based on across-strike and along-strike position to the length of the rift margin. Across-strike during marginal widening, crustal thinning becomes an increasingly significant factor. Extension and rift migration create an arrangement of domains with distinct structural characteristics (Peron-Pinvidic et al., 2013). Along-strike, the rift basin complex can be categorized into four types of basins based on regional geometries and the presence or absence of growth structures (Leleu et al., 2016). These regional associations are due to first-order controls on subsidence and basin development which include inheritance, regional extension rates, regional similarities in lithology and rheology, and localized heat regimes along the margin. Combination of both across-strike and along-strike classifications gives a relatively accurate description of the geometry of any basin located within the rift margin system.

\section{Across-strike Classification}

Similarities in spatial, temporal, and structural segmentation across-strike to a continentscale rift margin are likely related to tectonic processes reliant on the mode of deformation, local thermal and rheological parameters, and inheritance of Paleozoic structures (Peron-Pinvidic et al., 2013). The mode of deformation is related to the phase, or evolutionary stage, of the rift margin. These phases include: 1) a stretching phase related to low extension values and localized deformation in the upper brittle crust; 2) a thinning phase related to moderate extension, $\beta$ values between 2.0 and 4.4, in which extensional deformation is transferred to successively lower levels in the crust in a process of coupling and migration; 3) a hyperextension and exhumation phase related to an estimated extensional value of around 5, where crustal thinning allows exhumation of mantle through complex fault and detachment geometries creating an amalgamation of 
continental and oceanic blocks; and 4) a magmatic phase related to production of oceanic crust and sea-floor spreading which can occur in either a magma-poor or magma-rich environment (Peron-Pinvidic et al., 2013). Differing processes in each phase create unique structural characteristics that can be used to define five distinct domains; the proximal, necking, distal, outer, and oceanic domains (Figure 8).

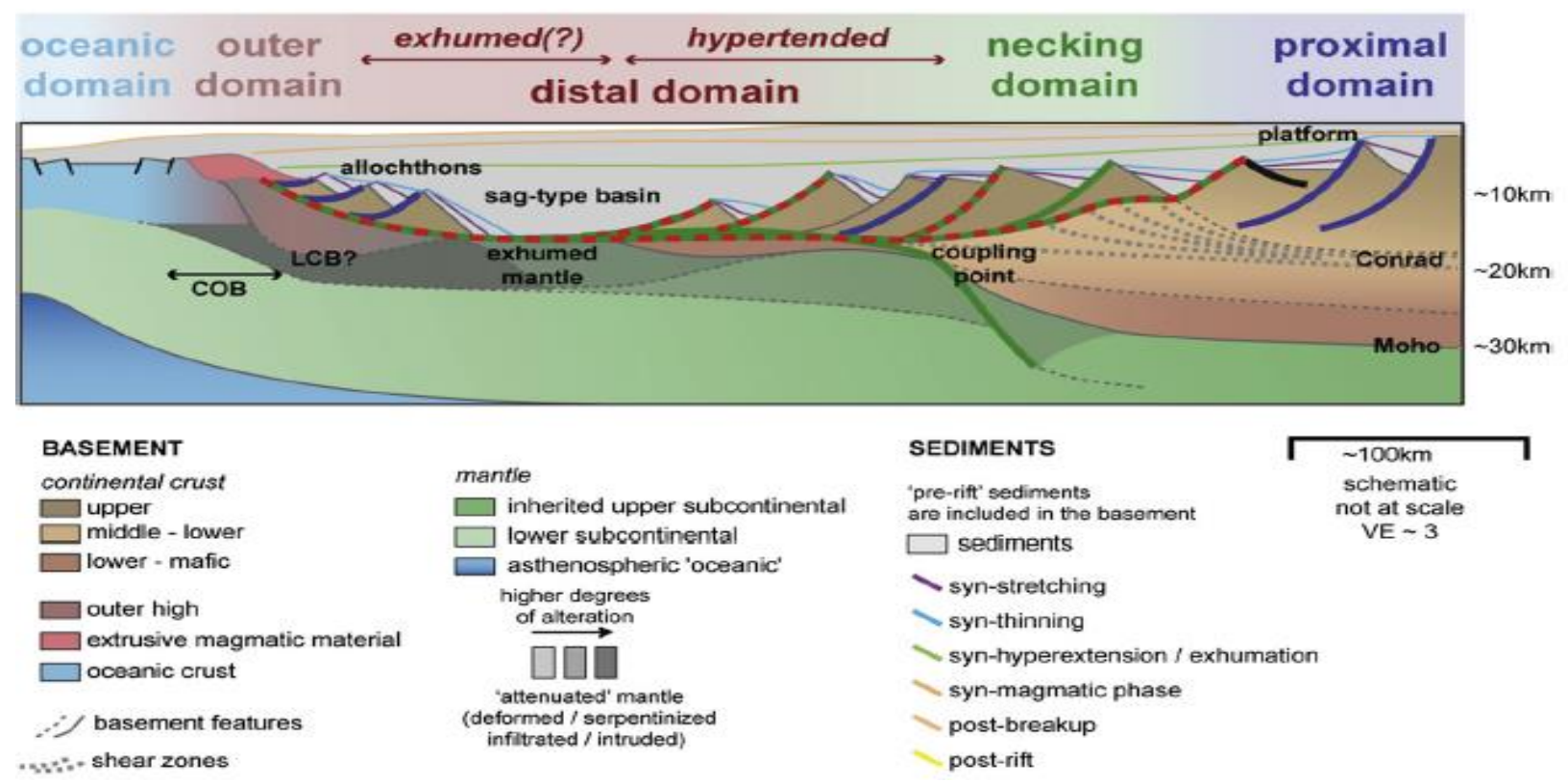

Figure 8: Schematic section of a typical rifted margin showing across-strike domains and approximate Moho position. (Peron-Pinvidic et al., 2013).

The proximal domain corresponds to interior continental rift basins with low extension values, half-graben formation, syn-tectonic growth structures, and modest accommodation space. Top basement geometries consist of tilted crustal blocks bordered by high-angle planar or listric normal fault arrays in the upper brittle crust with a possibility of deeper detachment surfaces that sole out at the brittle-ductile transition in mid-crustal levels (Peron-Pinvidic et al., 2013).

Deformation in the upper crust is uncoupled from lower crustal thinning at tectonic scales and is asymmetrically distributed at the surface as localized fault zones or rift basins.

Within the proximal domain, generally narrow, fault-bounded basin geometries developed early in the margin's history. A low-angle detachment surface beneath the continental 
margin likely created adjacent rift basins forming along subparallel border faults (Hutchinson and Klitgord, 1988). Paired basins, those in which border faults dip toward one another between adjacent basins, are common and exist in several places along the continental margin. Paired basins develop due to one basin forming along the master fault and the second forming at the main antithetic fault.

Many of these basins are exposed and well preserved, including the Deep River and Danville basins in North Carolina, because they are located on "platforms" compared to the rest of the more heavily subsided margin, where larger amounts of post-rift sedimentation have buried most basins. Preservation is partially due to the migration of rifting across-strike to the margin which ceased tectonic activity and subsequent deformation in the proximal domain relatively early on. Most deformation in these basins is associated with post-rift, cooling induced subsidence or inversion.

The necking domain relates to a wedge shape of the continental crust caused by drastic crustal thinning to less than $30 \mathrm{~km}$ of crustal thickness, in which the Moho and top basement converge (Peron-Pinvidic et al., 2013). At the outer end, the taper break is defined as the nearest point to the coast where the crustal thickness is reduced to less than $10 \mathrm{~km}$ (Peron-Pinvidic et al., 2013). This feature is located at the coupling point denoted in Figure $X$. The taper break limits the continent-ward segment, where deformation is decoupled between upper and mid-to-lower crust, and the oceanward segment, where deformation is coupled.

The distal domain corresponds to an area where the crust has thinned and hyperextended to less than $10 \mathrm{~km}$. Deformation is coupled at these crustal thicknesses allowing faults to run all the way through the lithosphere to the mantle (Peron-Pinvidic et al., 2013). Faulting of this nature produces exhumation of basalt, serpentinized mantle, and oceanic crust that becomes 
incorporated with hyperextended continental crust (Peron-Pinvidic et al., 2013). Recognized in seismic profiles by high seismic velocities, these magmatic intrusions, basalt wedges, and crustal underplatings affect subsequent subsidence and post-rift sedimentation.

The free-air gravity anomaly 'edge effect' at rifted continental margins has traditionally been explained as the consequence of the transition between thick continental crust and thin oceanic crust, and is located at the boundary between the necking and distal domains. (Wyers and Watts, 2006). The COB is characterized by gently dipping Mesozoic to Cenozoic sediments that overlie a much older, steeply dipping, Precambrian and Paleozoic basement or oceanic crust. Mesozoic and Cenozoic post-rift sediments are most voluminous in the distal domain. Post-rift sedimentation reaches its maximum thickness, approximately $15 \mathrm{~km}$, beneath the outer shelf and slope, but it extends onshore where it forms part of the East Coast, USA coastal plain.

Sediment thickness varies along-strike to the NA continental shelf such that depressions with thick sediments are separated by platforms with thinner sediments (Schlee, 1981). Together, the depressions and platforms give the shelf a distinct structural segmentation, referred to as embayments and arches, respectively (Wyer and Watts, 2006). It is unclear if these structures predominantly formed from asymmetric crustal thinning, variable heat flow conditions, or postrift flexure and Moho displacement, but they are structurally characteristic of the distal domain of the NA rift margin, where thinning and subsidence is greatest.

The outer and oceanic domains mark the transition from amalgamated crust to unambiguous oceanic crust. These domains are best described as either magma-rich or magmapoor and are responsible for the development or absence of large igneous provinces, such as the CAMP event, and associated with continent break-up and the initiation of seafloor spreading. By some interpretations, the outer domain represents the closure of the across-strike oriented sag- 
basin which results from subsidence and overarches both the necking and distal domain. These basement rises are described by terms such as marginal high and outer high (Peron-Pinvidic and Manatschal, 2010). For some margins, this domain corresponds to the seaward termination of allochthonous salts (Moulin et al., 2005). Basement lithology for the outer domain is poorly understood, but recovered basement is composed of exhumed mantle with intrusive and extrusive mafic material (Peron-Pinvidic et al., 2013). Seismic profiles show that crustal thicknesses are larger than in the distal domain, possibly due to serpentinization, affecting crustal isostasy and resulting in basement highs. The oceanic domain is the last to develop and corresponds to fully mature oceanic crust developed by seafloor spreading basalts.

\section{Along-strike Classification}

Rift basins can be categorized along-strike to the NA rift margin based on regional associations in basin geometries and the presence or absence of growth structures. Growth structures are wedge-shaped sedimentary packages along the fault boundary that demonstrate sedimentation was occurring simultaneously with faulting. Their absence suggests that basin formation happened quickly and stabilized afterwards with little later growth. Although generally well preserved, several processes can modify them after formation including inversion from sea floor spreading in the southern basins, to complications in the northern basins by depth, salt movement, and diapir development during late margin evolution (Leleu et al., 2016).

The NA Atlantic rift basin complex is geographically distributed into three segments, the southern, central, and northern segments based on the diachroneity of seafloor spreading along the NA margin (Withjack and Schlische, 2005). This diachroneity caused variances in the timing of both the end of rifting and the production of oceanic crust between each segment resulting in large, regional, structural and geometric associations. Boundaries between each zone correspond 
to first-order crustal lineaments, some of which, like the South Atlasic Fault zone, can be traced across the Atlantic domain to an onshore American lineament known as the Brevard BowenCreek Fault Zone (Withjack and Schlische, 2005).

Southern Segment basins, from Georgia to Virginia, are narrow, small-to-medium sized basins with limited or no growth structures. Central Segment basins, New Jersey to Nova Scotia, are wide, medium-sized basins with growth structures along bounding faults. Northern Segment basins, north of Newfoundland, are large, extremely wide basins which may have developed more from regional subsidence rather than distinct faulting mechanisms, similar to a sag basin (Leleu et al., 2016). The geometry of rift basins can also be divided into zonal types that reflect geographical associations: The Type A zone forming part of the Central Segment, the Type B zone covering the Southern Segment and southern part of the Central Segment, the Type C zone distributed over part of the Central Segment and the conjugate Moroccan margin, and the Type D zone which includes the Newfoundland and conjugate Portugal margins (Leleu et al., 2016).

These four main types of basins can be divided into two additional sub-types which vary systematically from south to north (Figure 9). Type A basins such as the Hartford Basin and Fundy Basin are wide to very wide basins (30 to $70 \mathrm{~km}$ ) that show syn-rift sedimentary wedge structures along the main border fault (Leleu et al., 2014). Sub-type AA basins show subtler growth-structures than other type A basins. Truncation of half-graben fills is common among basins of this type and is often covered by a tabular upper Triassic unit over regional scales (Leleu et al., 2016). 


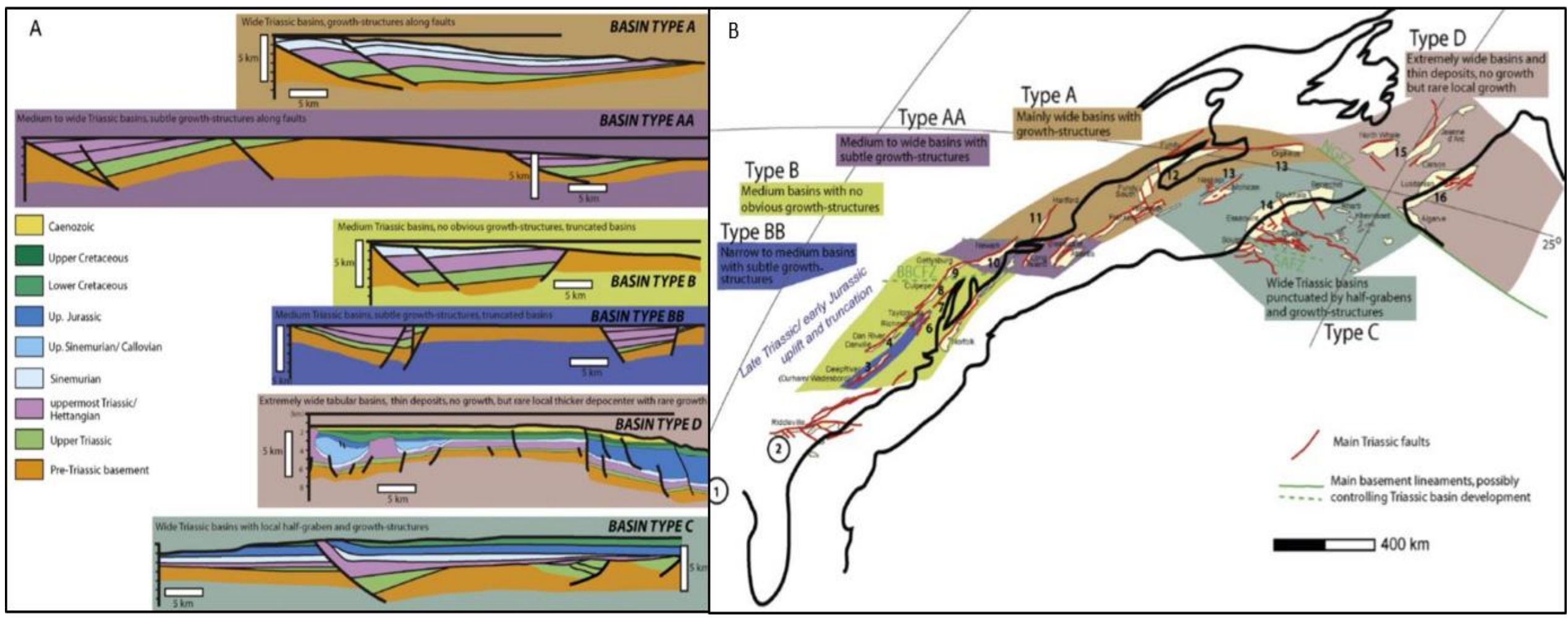

Figure 9: A) Main basin types and additional sub-types found in regional segments along the rift margin. B) General zones in which basin types are found. (Leleu et al., 2016) 
Type B basins such as the Dan River Basins, Culpeper Basin, and offshore Norfolk Basin are remnant basins that are narrow to medium width (10 to $25 \mathrm{~km})$ and show either no obvious growth structures or very subtle growth-structures (Leleu et al., 2014). Sub-type BB basins, such as Taylorville, Richmond and Deep River Basins, show better growth-structures than other type B basins, which thicken toward the border fault. The North Carolina part of the Southern Segment is classified as having type B and type BB geometries (Figure 10). In most Triassic rift basins, border faults are commonly segmented with varying strike and the footwall is only slightly uplifted while the hanging wall undergoes most of the movement along the detachment fault (Schlische, 1993). In half-graben basins like Type B, the hanging walls margin is most commonly represented by shallowly dipping antithetic faults with minor rotation (Schlische, 1993). Both growth structures and basin geometry, however, can vary significantly between adjacent basins.
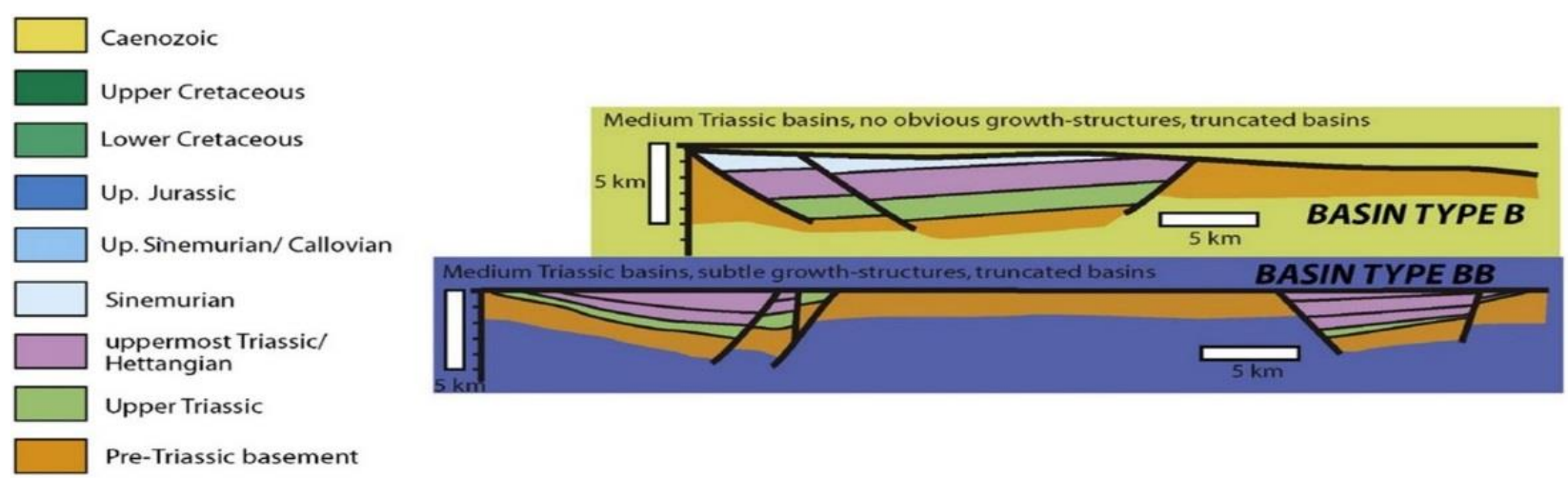

Figure 10: Basin types found in the Southern segment of the North American rift margin. (Leleu et al., 2016)

Type $\mathrm{C}$ basins are relatively small half-grabens (5 to $20 \mathrm{~km}$ wide) with growth-structures overlain by very wide basins, often filled by salt-rich deposits (Moroccan basins). Some of the small half grabens are truncated beneath the salt succession but in other places they appear conformable. Type $\mathrm{D}$ basins are very wide remnant basins, greater than $50 \mathrm{~km}$, displaying mainly tabular geometries developed beneath the salt deposits. Beneath the salt, grabens with 
slightly thicker deposits occur locally, and half-graben geometries which wedge toward faults are recognized but not frequent (Leleu et al., 2016). Type D basins are located in the Northern Segment and correspond to the offshore Newfoundland basins together with the conjugate Portuguese basins where geometries are better defined. 


\section{Chapter 4: Triassic Rift Basins}

The breakup of Pangaea was marked by the formation of rifted crust all along the axis of the proto-Atlantic Ocean, from Greenland to Mexico. Triassic rift basins within the NA rift margin are part of a sinuous belt of rift basins extending north to Nova Scotia and Newfoundland and south to southern South Carolina. From South Carolina, the buried South Georgia basin extends west southwesterly into Georgia and Alabama, linking the northeasterly strike of the North Atlantic rifts with the westerly orientation of buried Triassic rift basins along the northern

edge of the Gulf of Mexico (Figure 11) (Olsen et al, 1991). Although Mesozoic rift basins buried beneath the Gulf Coastal Plain formed coevally and under similar tectonic settings, their rifting history has been largely ignored in relation to eastern NA rifting.

Along the eastern NA rift margin, from southern New York to Georgia, the western-most exposed rift basins overly a relatively undeformed Precambrian-early Paleozoic cratonic crust that forms an east-dipping ramp. More eastern basins form at the boundaries between or within accreted terranes of the Piedmont. For regions north of this, the western-most basins lie east of the Appalachian gravity gradient and basement ramp, completely within the Piedmont Province. Most NA rift basins are normal fault-bounded half graben basins which appear to have formed on reactivated inherited Paleozoic structures.

According to the model of Ratcliffe and Burton (1986), the major direction of slip on reactivated faults and the relative amount of basin subsidence depend on the orientation of extension and the fault dip relative to the regional NW-SE trend of the rift margin. Therefore, the deepest parts of the half graben tend to lie adjacent to faults which are oriented NE-SW, and the 
shallowest parts of the basins tend to lie adjacent to faults that trend closest to NW-SE. These latter faults sometimes link adjacent basins and are referred to as transfer faults (Gibbs, 1983).

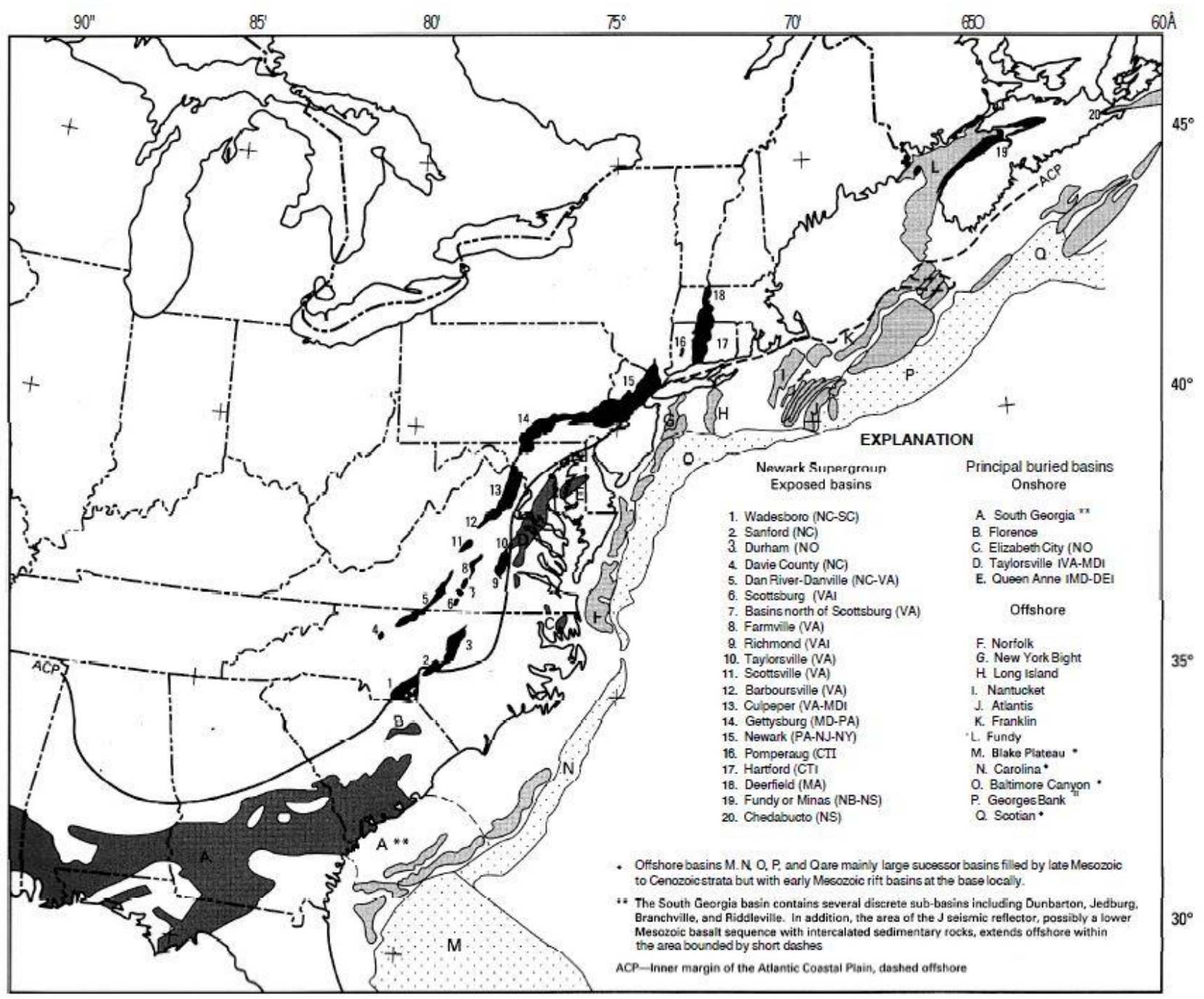

Figure 11: Distribution of Newark Supergroup basins and related buried basins along the eastern United States seaboard. (Olsen et al., 1991)

\section{Faulting}

Schlische (1991) constructed several models of faulting associated with both rift margin and basin development which includes three end-member types of faulting. These models include: 1) a detachment fault consisting of a listric fault that grades into a sub-horizontal detachment complex, 2) a series of tilted fault blocks, and 3) a fault growth model consisting of 
planar normal faults that grow in length, width, and overall

displacement through time. Each model results in a different rate of volume increase, producing distinct stratigraphy and stratigraphic successions (Figure 12). These stratigraphic features can often help constrain the geometry and evolution of a rift basin by providing insight to the degree of extension and displacement during formation. A specific tripartite stratigraphic pattern common to most of the Newark Supergroup basins has

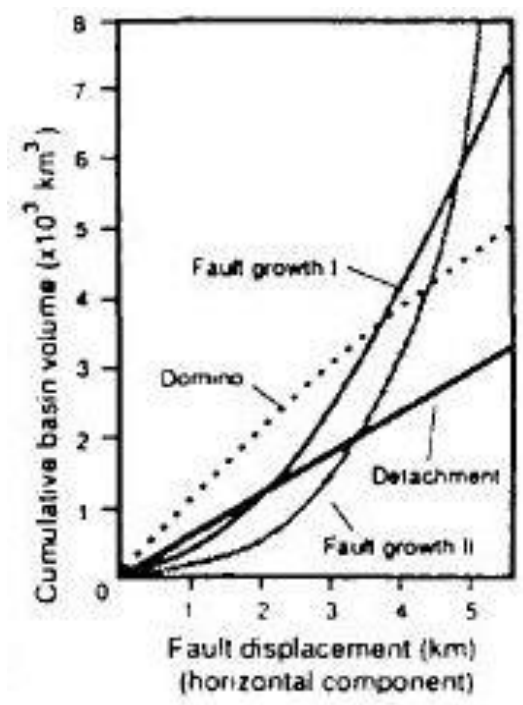

Figure 12: Basin volume growth due to amount of fault displacement for different types of faulting. (Schlische, 1991) been interpreted as an expression of fault growth, signifying it is the dominant faulting mechanism throughout the NA rift margin (Olsen and Schlische, 1988; Olsen et al, 1991).

The simplest model considered is the detachment fault which only considers uniform plane-strain along a listric fault that is bounded laterally by vertical transfer faults (Gibbs, 1983). In this model, pure shear strain pulls the hanging wall away from the footwall by translation on the sub-horizontal detachment resulting in potential voids between fault blocks (Schlische, 1991). Collapse of the hanging wall combined with the nature of deformation results in the formation of a half graben. Deformation can occur thru different means including zones of vertical shear, development of antithetic faults of differing dip angles, and bedding-plane shear within the hanging wall block (Figure 13); all controlled by equal-area balancing (Gibbs, 1983). In general, the structure of the half graben becomes wider and less deep with decreasing dip of the antithetic faults. Also, rift basins become narrower and deeper as the dip of the basin's bounding fault and depth to detachment increase which, in turn, can affect the dip of any antithetic faults (Schlische, 1991). Another possible geometry is a flat-bottomed half-graben with 
a ramp-flat geometry that results due to rollover of the hanging wall when the void between fault blocks is invariable over larger extents of the basin's length (Schlische, 1991). A feature unique to detachment faulting is that the change in the volume of the basin is constant through time due to the uniform plane-strain that generates undeviating spatial separation between fault blocks.
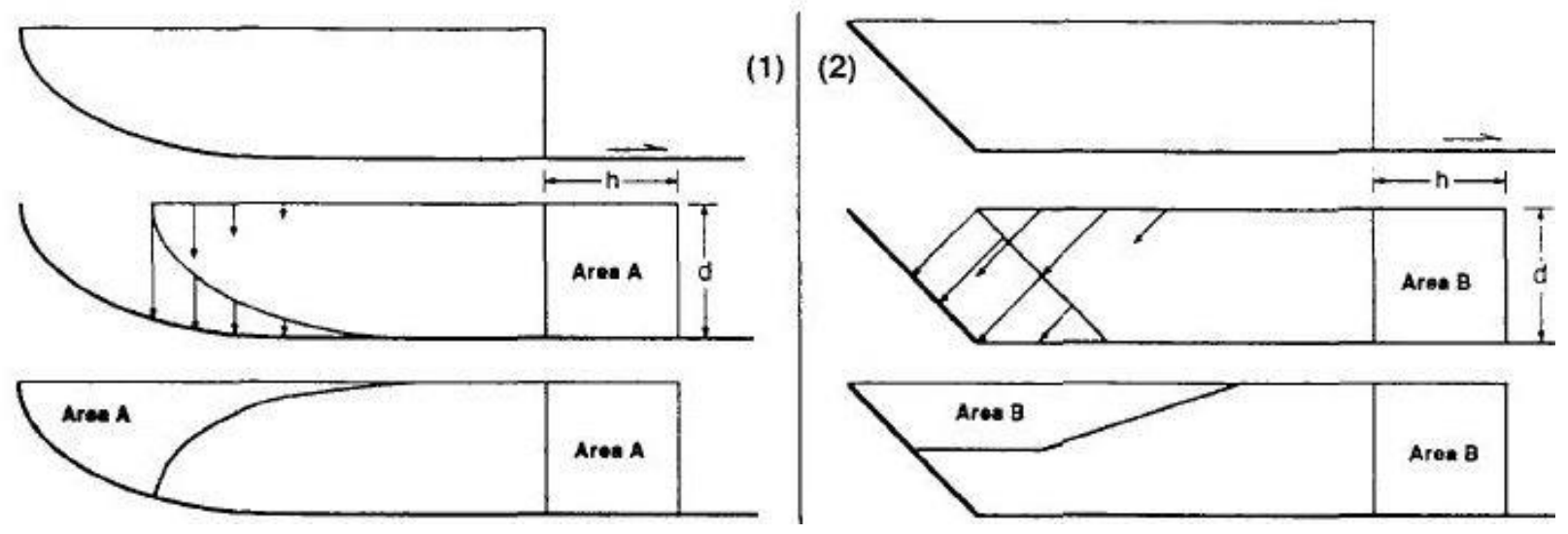

Figure 13: Detachment faulting due to uniform plane-strain bounded by vertical transfer faults. 1) Collapse of the hanging wall through vertical shear. 2) Collapse of the hanging wall through development of antithetic faults. (Schlische, 1991)

The second end-member type of faulting results in a series of tilted, domino-style fault blocks. Models for this type of faulting also assume uniform plane strain with basins bounded laterally by vertical planar faults. First recognized in the Basin and Range Province of the western United States, this style of faulting includes rotation of both the faults and the interior fault blocks above a detachment horizon (Emmons and Garrey, 1910). During extension, fault blocks rotating on planar or listric faults produce detachment horizons that are non-horizontal and a series of faults that continually decrease in dip with increasing extension (Schlische, 1991). This results in a series of fault blocks with decreasing cross-sectional areas. At some point, slip on low angle normal faults due to rotation becomes impossible and a new generation of more steeply dipping domino-style faults may form (Schlische, 1991). Models under simple conditions have mimicked this process based on a mathematical relationship between the amount of extension, the fault spacing, and the rotation/deformation of the fault blocks (Figure 14) 
(Wernicke and Burchfiel, 1987). Unique to this style of faulting is that the rate of volume growth of the basin under uniform extension decreases through time.
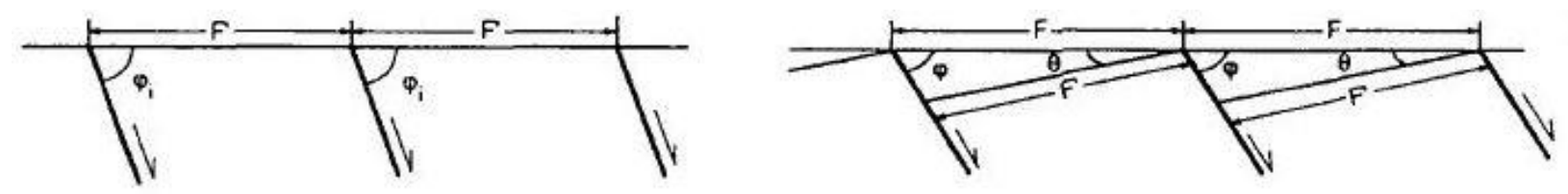

Figure 14: Domino-style fault block model in which both the faults and fault blocks rotate during extension. $\Phi_{i}$, is the initial dip angle of the faults; $\Phi$ is the dip after extension; $\boldsymbol{\theta}$ is the dip of a horizon that was horizontal before extension; $F^{\prime}$ is the initial fault spacing; $F$ is the fault spacing after extension. (Schlische, 1991)

The last end-member type of faulting are faults that grow through time. In this scenario, short faults with small maximum displacements grow into larger faults with greater maximum displacements. Fault-bounded sedimentary basins that obey fault growth models are expected to grow in length and width through time with displacement along normal faults generally greatest at the center decreasing to zero at its termination points (Figure 15) (Gibson et al., 1989;

Schlische, 1991). Mesozoic half graben basins of the NA rift margin are demonstrably deepest at the fault center and decrease in depth towards all termination points of the basin (Schlische, 1990b). 

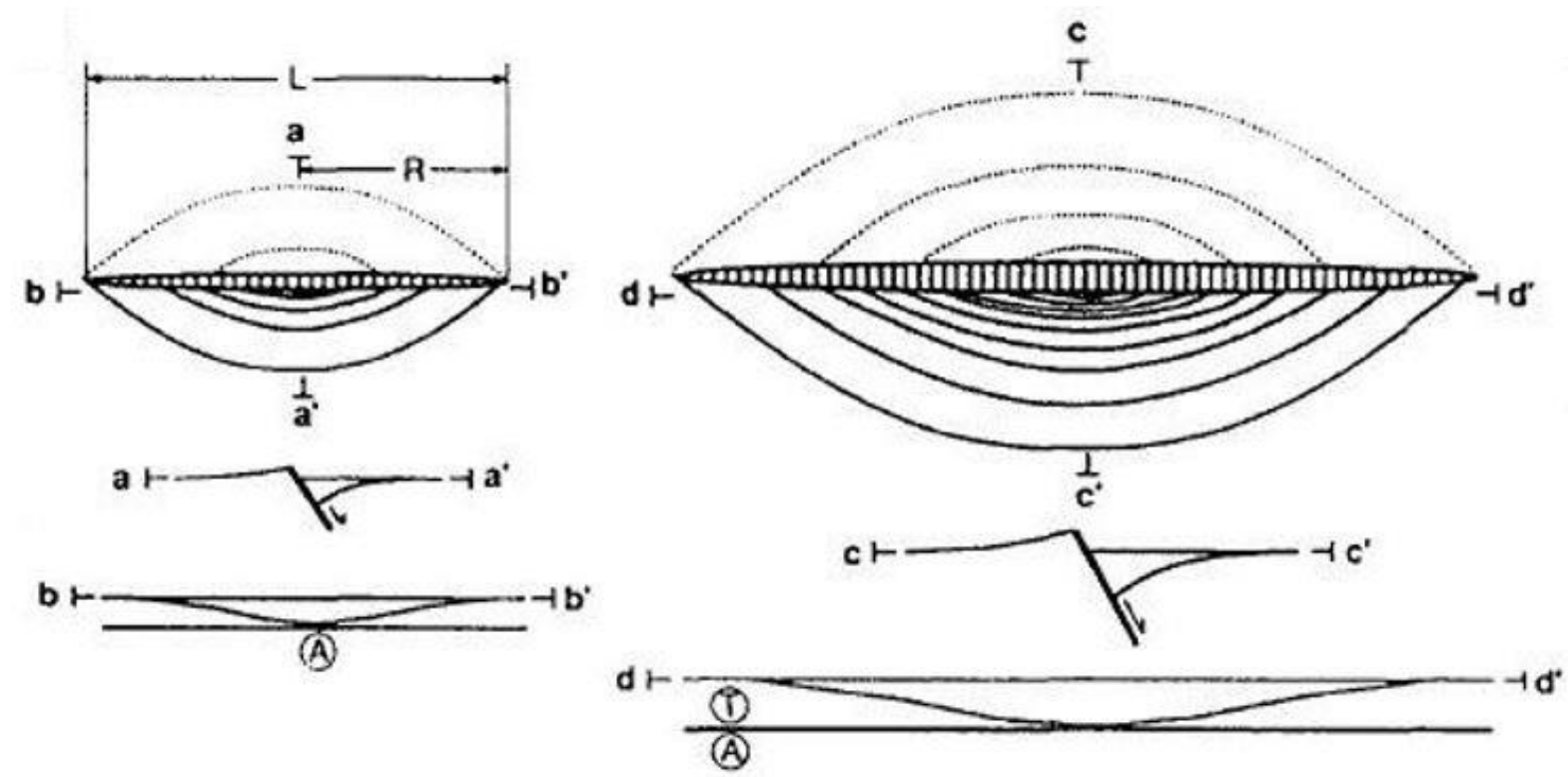

Figure 15: Essential elements of the fault growth model in which displacement is greatest at the fault center. $\mathbf{L}$ is the length of the fault, $\mathbf{R}$ is the radius of the fault $(\mathbf{L} / \mathbf{2}), \mathbf{T}$ is fault motion toward the reader, $\mathbf{A}$ is away. (Schlische, 1991)

There are two different models that describe the possible mechanisms for fault growth.

The first is dependent on the overall fault length which results from increasing displacement during successive slip events. As the fault grows, stresses must be large enough to encompass the entire fault length and to also fracture intact rock at the termination points (Schlische, 1991). At some critical length, however, rupture length, stress, and displacement become independent of fault length and growth ceases. The second model assumes localized stress from displacement at the ends of the fault during slip events is large enough to increase rupture length and lengthen the fault independent of the overall length and displacement at the center of the basin. In this case, there is no maximum fault length that can be reached as long as displacement occurs. The difference between fault growth models is a small variation in the scaling law of fault propagation derived from dip-slip faults in a variety of tectonic settings and lithologies (Watterson, 1986; Cowie and Scholz, 1990). Despite uncertainty in the fault propagation 
mechanism responsible for growth, the change in the rate of volume increase of the basin is positive through time.

Triassic subsidence of hanging walls of major normal faults and concurrent uplift of rift flanks produced half grabens that were filled by continental fluvial and lacustrine clastics (Olsen et al., 1991). For the case of rifting and sedimentation occurring simultaneously, a reverse drag fault geometry develops in sedimentary horizons that is akin to roll-over of the hanging wall. The radius of reverse drag faults from the master fault grows with increasing displacement and with greater subsidence in the hanging wall than uplift in the footwall. This effect complicates understanding of the formation of half grabens within basins due to indistinguishable similarities between reverse drag faulting, roll-over of the hanging wall, and syn-rift growth structures such as sedimentary wedges. Despite this, observed tripartite stratigraphy in North American Mesozoic basins most closely resembles patterns generated by fault growth models (Figure 16) in which fluvial strata progressively onlap pre-rift rocks, and lacustrine strata that pinch out against or onlap syn-rift rocks in the center of the basin and onlap pre-rift rocks at its lateral edges (Schlische, 1991). 


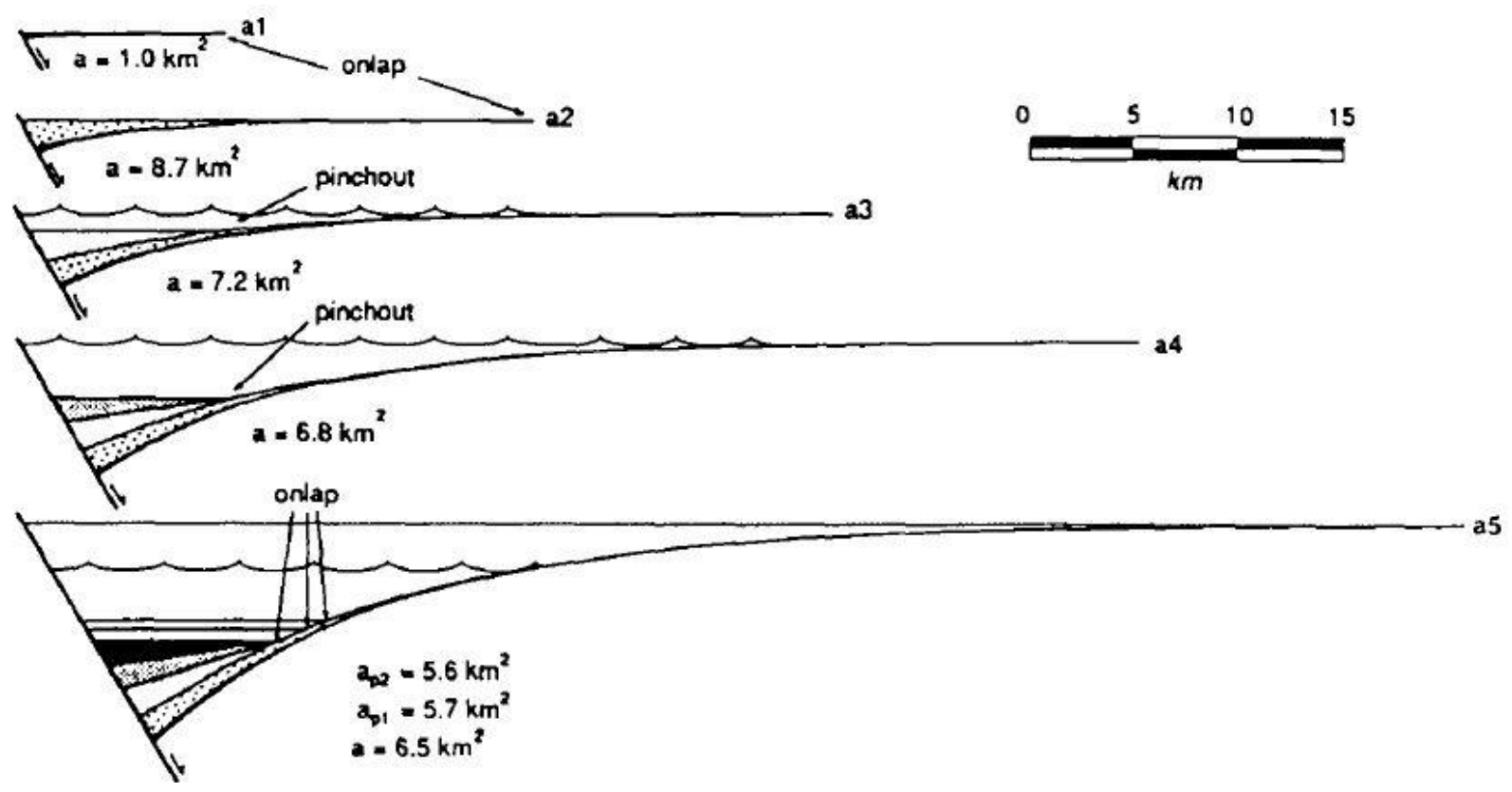

Figure 16: Pattern of basin infill for the fault growth model of extension. Fluvial syn-rift sediments are stippled; lacustrine sediments are shaded gray; post-rift sediments are horizontal. Cross-sectional area for syn-rift strata is (a), and $A_{p 1}$ and $A_{p 2}$ for the post-rift sedimentary wedges. (Schlische, 1991)

\section{Sedimentology/Stratigraphy}

Since rift basins along the North American Atlantic margin have undergone similar formation and development, broad stratigraphic patterns can be correlated between basins despite complications of later deformation due to inversion, diapirs, and other processes. Details of sedimentation in the Central Atlantic domain basins vary due to differences in inherited structures, accommodation space, timing, paleoclimate, and paleogeography, but basins retain a tripartite stratigraphy known as the Newark Supergroup (Leleu et al., 2016). This tripartite stratigraphy demonstrates an evolution of basin infill that progresses through a group of sedimentary and fluvial associations recognized as universal types of formations found in Newark Supergroup basins. The Newark Supergroup basins filled with principally red continental clastics and minor tholeiitic basalt flows over a period of 30 to 40 million years, 
ranging from the Late Triassic to the Early Jurassic. This stratigraphic sequence exists with predominantly fluvial units in the lowermost sections, a predominantly lacustrine intermediate section usually containing deep-water facies in southern basins, and an uppermost unit consisting of shallow water lacustrine deposits overlain by fluvial strata (Schlische and Olsen, 1990). For most of the margin, sedimentary features, caliche (carbonate nodes), authigenic minerals, and pseudomorphs suggest an arid to semi-arid paleoclimate (Lorenz, 1988; Van Houten, 1964; Smoot, 1991). However, coal beds formed in several southern basins that had deeper lakes for extended periods suggest local humid conditions. A major basal unconformity is recognized across the wide rift zone and may represent a period of uplift or contractional inversion (Huismans and Beaumont, 2014). Also, because every basin is ultimately filled over time, an unconformity caps each.

During continental breakup, paleolatitudes transition between climatic regions, drainage patterns shift, and uplift and subsidence occurs, all of which may alter basin geometry and sedimentary infill. Depositional models must consider large amounts of time for the basin infilling process, on the scale of 10-20 million years, and cannot be assumed to be constant. Temporal variations in both the sedimentation rate and fault-controlled subsidence are difficult to determine in continental rift basins due to poor age estimates. Ages and dates throughout the evolution of the rift margin have been estimated, however, by radio-isotope analysis of dikes, astronomical cycles in lacustrine strata, and growth structures. Diverse sedimentary facies in the basins also provide insight to regional tectonic and climatic controls, and stratigraphic patterns provide understanding into the correlation between present-day basin boundaries and their original structures (Smoot, 1991). 
For continental extensional basins, the main relationship regulating basin infill is that between sedimentation and subsidence rates. In general, sedimentation rates are predominantly influenced by climatic factors and subsidence rates are controlled by tectonic events. If the sedimentation rate exceeds the subsidence rate, the basin will fill to its lowest outlet with excess material flowing out. This environment allows for through-going streams and rivers creating fluvial systems. If the subsidence rate exceeds the sedimentation rate, more accommodation space is available than sedimentation volume and a hydrologically closed basin forms allowing little to no drainage or loss of material. In this case, depending on the amount of water available, shallow and/or deep lakes can develop. Lacustrine sedimentation dominates in this type of environment with fluvial, deltaic, and marginal lake environments forming around the body of water (Schlische, 1991).

The geographic and stratigraphic distribution of these units within each basin allow for comparison of depositional, climatic, and tectonic environments for basins along the NA rift margin (Smoot, 1990). A table of lithofacies descriptions and interpretations of main paleoenvironments can be seen in Appendix A. This relationship between sedimentary units and facies indicate climate change occurred over large time periods and across paleolatitudes, which is mirrored by cyclic fluctuations in lacustrine deposits on the scale of meters to hundreds of meters of stratigraphic thickness (Van Houten, 1962; Olsen, 1986). The full range of precession-related periods of lake level change are present, including the two peaks of the $\sim 20,000$ year cycle of climatic precession, the two peaks of the $\sim 100,000$ year eccentricity cycle, the single peak of the 412,900 year eccentricity cycle, and the $\sim 2,000,000$ year eccentricity cycle (Olsen and Kent, 1996). In many Mesozoic basins, fixed-period Milankovitch cycles indicate a general trend of decreasing sedimentation rates after the onset of lacustrine deposition in the Triassic, followed 
by a five-fold increase by the Early Jurassic, and then by another decrease afterwards (Schlische and Olsen, 1990).

In half-graben basins, transitions from one facies to another must be the consequence of some combination of either a change in the sedimentation rate or an increase in the volume of the basin by tectonic activity. As sedimentation occurs simultaneously with fault-controlled subsidence and production of accommodation space, wedge-shaped sedimentary units form next to the displacing faults, recognized as growth structures. The same syn-rift strata onlap and pinch out on the hanging wall block creating a characteristic pattern of deposition. In fault growth models, the rate of volume increase in the basin is positive through time. This relative increase in accommodation space compared to relatively constant sedimentation causes initial fluvial deposition to naturally give way to lacustrine sedimentation (Schlische, 1991). Onlap of sedimentary strata onto the pre-rift hanging wall rocks is only possible if the sedimentation rate is constant and the basin is growing through time, otherwise sedimentary units will quickly begin sequentially stacking on other syn-rift strata.

In many Triassic basins, lacustrine deposits decrease in thickness upwards. This is explained by the same amount of material being deposited in a larger area resulting in thinner stratigraphic thickness. Thicknesses of strata can be affected by variation in sedimentation rates, but the onlap patterns onto the hanging wall, the decreasing thickness of sequential lacustrine strata, and similarities between basins all support fault growth models rather than large variation in sedimentation rates.

Sedimentary trends among basins create a stratigraphy with four principal lithofacies: Alluvial, fluvial, lacustrine, and lake margin. Each principal facies can be sub-divided into secondary facies types representing specific depositional environments (Appendix A). Triassic- 
age depositional environments within the NA rift margin consist of local alluvial fans, three

separate fluvial system types, and four lake types all related to continental environments with the exception that salt lake environments may be related to late-stage marine ingressions (Leleu et

al., 2016). Several of these depositional environments can be seen in Figure 17.

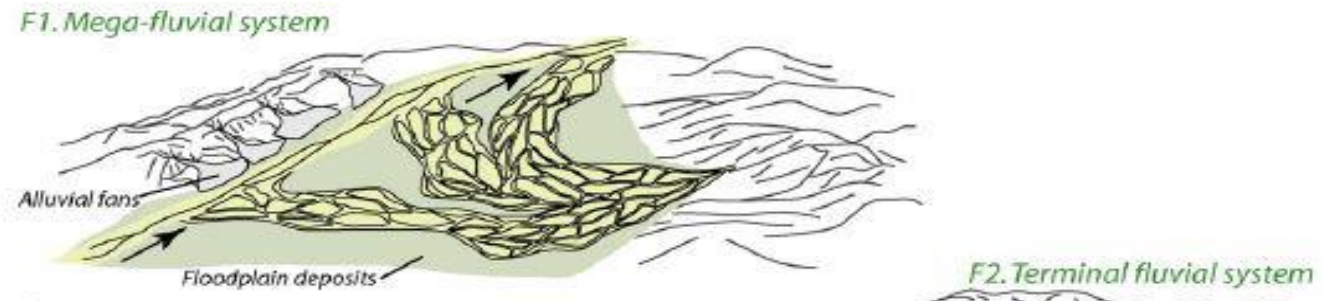

A. Fluvial-dominated basin, mostly transverse input

B. Model of basin dominated by fluvial splay and playa margin facies
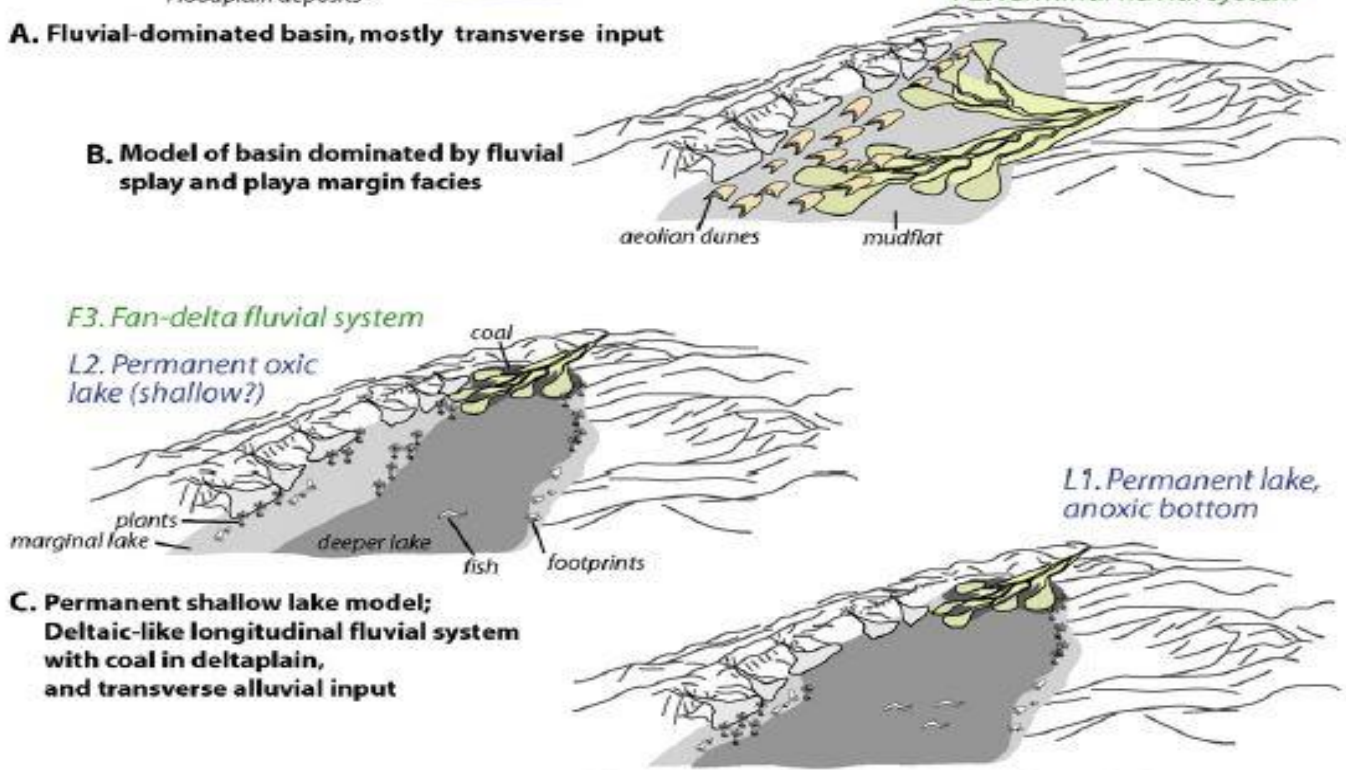

D. Permanent deep lake model; Deltaic-like longitudinal fluvial system with coal in deltaplain, and transverse L3. Playa lake (mudflat, alluvial input

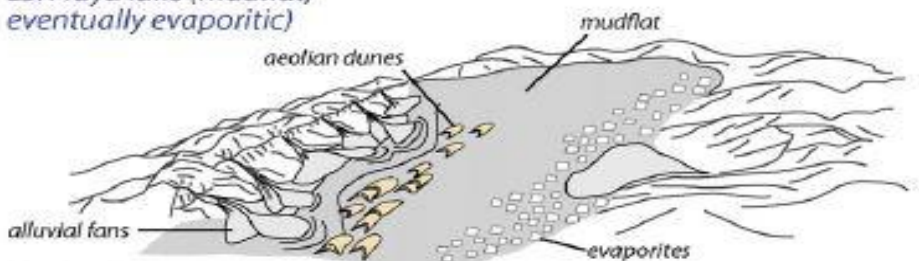

E. Playa lake/ mudflat (semi-arid) model

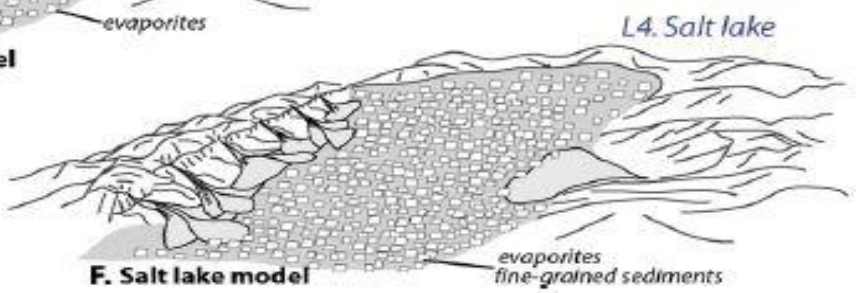

Figure 17: Schematic view of sedimentary models for depositional environments common to Newark Supergroup basins. Fluvial system types: F1 Mega-fluvial system, F2 Terminal fluvial system, F3 Fan-delta fluvial system. Types of lakes: L1 Permanent anoxic lake, L2 Permanent oxic lake, L3 Playa lake, L4 Salt lake. (Leleu et al., 2016) 
Alluvial-fan deposits include poorly sorted conglomerates and sandstones formed by fault uplift and low angle deposition near the bounding fault. These deposits have the same lithology as the faulted rocks and are present in almost all formations in each basin (Smoot, 1990). Because of this, they are not often defined as individual formations and are not considered as part of the tripartite stratigraphy. Composite thicknesses can reach thousands of meters that fine and pinch-out towards the distal margin and are intercalated with lacustrine and fluvial sedimentary rocks (Schlische, 1991). Alluvial fan deposits are often not continuous along the border fault due to fluvial systems that often form at throughout the deepest part of a basin, and are most commonly preserved at the distal edges of the fanglomerate that accumulate along a series of stepped faults (Smoot, 1990).

Fluvial facies are the most common depositional regime and include a wide range of depositional environments including meandering, braided, and possibly anastomosing streams and rivers within mega-fluvial systems, terminal fluvial systems, and fan-delta fluvial systems (Leleu et al., 2016). Periods of subsidence and topographic rejuvenation led to dominantly laterally extensive, dispersed fluvial deposition within basins (Leleu et al., 2016). Modern analogs such as the East-African rift system demonstrate that major fluvial systems seldom flow into rift basins and are often turned away by the uplifted rift shoulders. Fluvial systems within rift basins are axial or more often transverse systems represented by alluvial/deltaic fans in narrow basins and broad fluvial networks within wider basins sourced from the hanging wall dip slope (Leleu et al., 2016). As the fluvial system becomes unconfined, a loss of sediment transport capacity occurs, and deposition takes place. Although there are similarities between fluvial and low angle alluvial deposits, fluvial deposits are distinguishable by their primary structures, scale, extent, and the thickness of channel-fill (Smoot, 1990). Unique to this facies type is the 
association of thick mudstone deposits within the channels, scouring, cross-bedding, and lamination structures found within the strata. These fluvial systems then join a longitudinal system frequently developed along the bounding-fault (i.e. the deepest part of the basin) that may have connected a series of sub-basins. In the case of smaller drainage basins and fluvial systems, sedimentation may have ended in terminal splays and shallow ephemeral lakes or as lacustrine deltas within deeper lakes.

Lacustrine and lake margin deposits can be divided into four main types: shallow perennial lakes, deep perennial lakes and/or anoxic perennial lakes, shallow ephemeral playa lakes, and salt lakes (Olsen, 1990; Leleu at al., 2016). In general, non-rejuvenation of topographic highs in the proximal domain led to more lacustrine-dominated sedimentation within hydrologically closed basins (Olsen, 1990; Smoot et al., 1985). Playa and deep lake facies developed diachronously within Triassic rift basins. However, correlation between basins shows that fluvial and lacustrine deposition occurred contemporaneously, and it is important to understand the facies relationships within individual basins for paleo-reconstructions.

In Northern basins during the Triassic, deeper water facies are gradational from deeper lacustrine facies to shallower ones with eventual development of evaporites in the Early Jurassic. In Southern basins within the same period, deeper lacustrine facies developed with anoxic conditions resulting in the presence of coal beds and suggest wetter climatic conditions and influences on sedimentation. Southern basins are thought to have been located within the tropical climatic belt (Kent and Olsen, 2000; Kent and Tauxe, 2005). Southern basins were near the equator throughout much of the Triassic and exposed to cyclical wet-dry (monsoonal climate) conditions resulting in deposition of thick lacustrine strata (Olsen, 1980). Deeper and more numerous perennial lakes within Southern basins likely resulted from both the climatic 
conditions and structural architecture (Lambiase, 1990). Lacustrine thicknesses of 1,300 m to 3,000 m are commonly found deposited in Southern basins, although significant post-rift erosion may have occurred (Leleu et al., 2016).

Accurate and precise age control is important for correlation between basins, but ages are generally poorly constrained. Lacustrine deposits record fluctuations in climatic and paleoenvironmental conditions and have been used to assess correlations for continental strata among basins (Leleu et al., 2016). Formations, members and strata-specific hydrogeologic and geochemical environments reflect cyclic depositional environments. Evolving basin geometry coupled with orbitally forced climatic fluctuations controlled the long- and short-period environments (Olsen et al., 1996).

The shorter-period, wet-dry orbital cycles of about 20,000 (Van Houten cycle), 100,000 and 400,000 (McLaughlin cycle) years are evident in the rock record of the Lockatong, Passaic and younger formations as cyclic fluctuations in color, sedimentary fabrics, and organic carbon content that are associated with various lake levels (Olsen and others, 1996). A long-modulating cycle of approximately $2 \mathrm{~m} . \mathrm{y}$. is also recognizable, made up of 5 McLaughlin cycles. When used in conjunction with magnetostratigraphy, geochemistry, absolute dating of igneous intrusions, and other age-dating techniques, a chronostratigraphic framework can be applied for correlation at the basin scale (Olsen et al., 1996). Many recent studies have used these methods to correlate the Triassic units in the Newark Supergroup across continents and in marine/continental realms (Dal Corso et al., 2014; Schoene et al., 2010; Whiteside et al., 2010).

\section{Biostratigraphy}

Correlation charts for the various NA Triassic rift basins are based on freshwater floral and faunal fossils including fish, reptile, and amphibian remains, trace fossils, and palynomorph 
stratigraphy (pollen and spores). Palynofloral zones are well established worldwide allowing for the general definition of stratigraphy of most Mesozoic basins (Cornet and Olsen, 1985). In lacustrine deposits, fossil fish combined with palynology provide a robust stratigraphic framework and correlation scheme.

\section{Mineral Resources}

Early Mesozoic basins of the NA rift margin are associated with many potential resources including base metals, precious metals, and hydrocarbons. The distribution and geologic features of deposits within Newark Supergroup basins can be used with regional mapping, tectonic models, and geophysical and geochemical surveys to predict promising areas for future mineral/resource exploration. Characteristics of known deposits can also be used to classify occurrences into ore-deposit types. For base and precious metals, $\mathrm{Cu}, \mathrm{Au}, \mathrm{Fe}, \mathrm{Pb}, \mathrm{Ag}, \mathrm{Zn}$, barite, and fluorite found in Triassic basins, deposit types are generally categorized into three groups: those related to igneous activity such as diabase sheets and dikes, to non-igneous brine circulation, and to initial sedimentation of basin infill.

\section{Base Metals}

Metal occurrences related to Jurassic igneous intrusions and adjacent thermally metamorphosed rocks associated with Triassic rift basins have been used to classify ore-deposit types. These deposits are hydrothermal in origin and are related to tholeiitic diabase sheets, differentiates, and the surrounding alteration zones. Most of the intrusions and associated oredeposits are in the vicinity of the main, fault-bounded margin where the intrusions are in contact with pre-Mesozoic rocks. The deposits can be classified into three groups based on both spatial and temporal igneous associations and characteristic geochemical signatures: 1) Magnetite skarn and skarn replacements in marble bordering tholeiitic diabase sheets, 2) Hornfels copper deposits 
through metasomatic replacements in thermally metamorphosed calcareous siltstone and shales bordering late-stage, diabase differentiates (mainly ferrogabbro and granophyre), and 3) latestage igneous segregations and interrelated veinworks bordering diabase sheets (Robinson, 1985). Skarn-type deposits contain massive magnetite and trace amounts of pyrite, chalcopyrite, sphalerite, and accessory sulfide minerals enriched in $\mathrm{Cu}, \mathrm{Co}, \mathrm{Au}$, and $\mathrm{Ag}$. Hornfels deposits are enriched in $\mathrm{Cu}, \mathrm{Fe}$, and trace metals. Igneous segregations and bordering veins are enriched in $\mathrm{Cu}$ with localized trace metals including arsenic (Robinson and Sears, 1992). Magnetite skarn deposits are the most abundant, largest, and economically significant ore-deposit type associated with Mesozoic rift basins.

Migration of brines within the basins, unrelated to igneous activity, are associated with sediment-hosted, stratabound and vein-type mineral deposits. Sandstone-hosted deposits, associated with organic debris, are $\mathrm{Cu}$-rich and are often augmented in $\mathrm{Ag}$ and occasionally $\mathrm{U}$. Black-mudstone-hosted deposits are $\mathrm{Cu}$-and/or Zn-rich and occur as disseminated deposits, discordant veinlets, and replacements (Robinson and Sears, 1992). Base metals, barite veins, and replacement body deposits associated with faults, fractures, or shear zones are locally enriched in $\mathrm{Pb}, \mathrm{Zn}, \mathrm{Cu}, \mathrm{Ag}$, barite, and fluorite (Robinson and Sear, 1992).

Syngenetic metal occurrences, such as Au-placer deposits, formed during initial basin sedimentation. The origin of gold for these placer deposits is related to a peri-Gondwanan volcanic arc that docked onto the Euramerica Plate before the formation of Pangaea. Composition of the pre-Mesozoic volcanic rock is calc-alkaline which has a strong correlation with subduction-type rifting zones. A series of terranes further north, recognized as the Avalonia terrane, shows similar fossils and is known to have been peri-Gondwana volcanic arcs indicating a similar style of genesis and docking (Hibbard et al, 2002). Many types of ore deposits, 
including gold deposits, found in these exotic terranes were formed through several processes including orogenic-style shear zone deposits, high-sulfide epithermal deposits, low-sulfide epithermal deposits, and volcanic massive-sulfide deposits with disseminated or massive distribution. Mesozoic rift basins that formed within these terranes, such as the Danville and Deep River basins, accumulated gold as secondary placer deposits derived from Paloezoic (or older) igneous and metamorphic rocks that border the basins.

Of 276 occurrences of ore-deposits throughout Newark Supergroup basins, only a handful are mined in North Carolina (Appendix B). Of those, the most common are Au mines found in either Triassic sandstones or Quaternary sediments as placer deposits. Several copper mines and a single barite mine are also located in North Carolina. Both the copper and barite oredeposits formed by migration of basin brines in a non-volcanic environment. The copper ore is stratabound vein-type/replacement deposits derived from metavolcanic rocks, and the barite ore formed on the periphery of a diabase sheet as veins. (Robinson and Sears, 1992).

\section{Oil and Gas}

Total organic carbon is the first-order control on the potential of source rocks to produce oil or gas. The minimum amount of organic matter needed to develop oil from a shale source rock is $0.4 \%$ to $1.4 \%$ total organic carbon (TOC) (Dow and O'Connor, 1982). Source rocks in Mesozoic rift basins that reach this threshold are more likely to produce gas than oil due to their high thermal maturity and type of organic matter (Tissot and Welte, 1978). Organic matter kerogen type is determined by the hydrogen index $[\mathrm{HI}]$ and the oxygen index

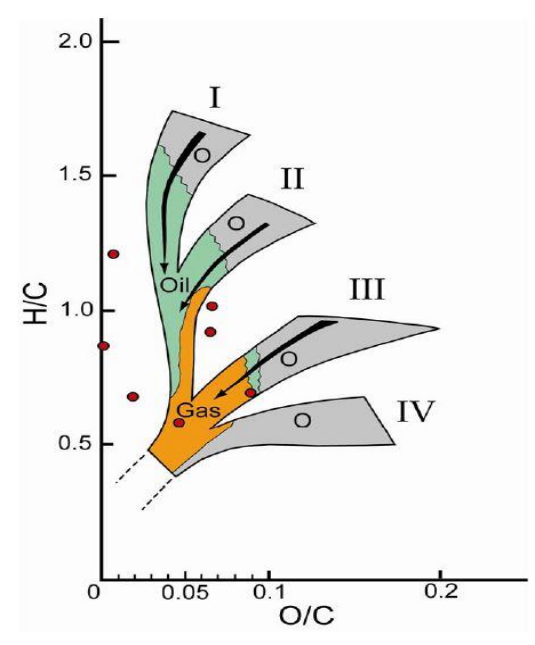

Figure 18: $\mathrm{H} / \mathrm{C}$ and $\mathrm{O} / \mathrm{C}$ ratios of kerogen types and hydrocarbon development. Red circles are samples from the Deep River basin. (Reid and Milici, 2008) 
[OI] which relates the primary kerogen type to the likelihood of hydrocarbons developing as oil, gas, or both (Reid and Milici, 2008). Type I organic matter (algal, lacustrine) generates primarily oil; type II (marine, reducing environment) generates both oil and gas, and type III (plant derived) generates primarily gas (Tissot and Welte, 1978). Type I and III kerogens are commonly found in southern basins, which are associated with lacustrine environments (algal) and coal beds (plant derived) that developed in more humid/swampy conditions (Figure 18). The genetic potential of source rocks for hydrocarbon generation in Southern segment Triassic rift basins is moderate to high based on geochemical signatures in black shales and coal beds.

Interest in hydrocarbon potential of Mesozoic basins located in the Southern segment of the NA rift margin exists due to the presence of relatively thick source rocks and reservoir beds, a variety of possible traps, and documented oil and gas shows in the other exposed Newark Supergroup basins (Olsen et al., 1991). Available geochemical data that can determine thermal maturity is poor, however, due to the presence of Jurassic intrusions that heated and metamorphosed source rocks, sediments, and organic matter masking the unaltered potential for oil and gas (Reid and Milici, 2008). In some basins, heat from these intrusions and unknown contributions by burial depth have contributed to elevated thermal maturity profiles. The U.S. Geological Survey assessed the technically recoverable, undiscovered, hydrocarbon potential of the Triassic rift basins as containing an estimated potential of 3,860 billion cubic feet of gas (Milici et al., 2011).

In the Carolinas, organic geochemistry data show that potential source rocks exist in the Deep River basin and sub-basins and the Dan River/Danville basin, and that the sediments are gas prone rather than oil prone, although both types are found (Reid and Milici, 2008). In the Deep River basin, the thick, organic-rich, coal-bearing shales of the Cumnock Formation of the 
Sanford sub-basin are thermally mature with respect to oil generation (Pratt et al., 1985; Robbins and Textoris, 1986). In 1983, gas and oil were recovered from fractured rocks in deep holes that ultimately proved to be noncommercial (Ziegler, 1983). Unlike the Sanford sub-basin, the volume of potential source rocks in the Durham and Wadesboro sub-basins is negligible and has not warranted serious exploration, even though the thermal maturity is also appropriate for oil generation (Olsen et al., 1991). In contrast to the Deep River basin, the exposed organic-rich rocks of the Dan River basin are over-mature with respect to oil generation due to advanced burial diagenesis and poor porosity and permeability. Additionally, the strata are faulted and dip at relatively high angles due to inversion, indicating that possibilities are very limited for intact reservoirs and traps (Olsen et al., 1991).

\section{Arsenic}

The occurrence, concentration, and species of arsenic (As) in basin groundwater is related to location, hydro-geochemical environment, and the type and extent of source rock (Serfes et al., 2010). Widespread distribution of detectable arsenic is derived from naturally occurring minerals as non-point sources of contamination in Mesozoic rift basins (Serfes et al., 2010). Elevated arsenic has been identified within sedimentary aquifers of the Mesozoic rift complex and metamorphosed clastic sedimentary units (Chapman et al., 2013). Arsenic is a component in over 200 naturally occurring minerals including sulfides, oxides, and silicates (Smedley and Kinniburgh, 2002). Iron-oxide minerals such as hematite, sulfide minerals such as pyrite, and the surface of clay minerals are all potential sinks and sources of As. Two geologic units, Triassicaged sedimentary rocks and Triassic-Jurassic intrusives, generally have higher concentrations of arsenic in groundwater than other geologic units (VanDerwerker et al., 2018). Geological processes that constrain the occurrence and abundance of arsenic include: the depositional 
geochemical environment, subsequent diagenesis, the stability of primary minerals, and development of secondary minerals, (Serfes et al., 2010).

In the Triassic sedimentary rocks and the Triassic-Jurassic intrusives, between $15 \%$ and $23 \%$ of samples taken in Virginian rift basins exceed safe As concentrations of $5 \mu \mathrm{g} / \mathrm{L}$, respectively (VenDerwerker et al., 2018). This is a 6-fold and 13-fold increase in likelihood of arsenic contamination compared to other geologic units in the region. Mobile arsenic in groundwater, however, is most closely related to geochemical cycles of iron, sulfur, and clay minerals (Stollenwerk, 2003), and the most prevalent mechanisms controlling mobilization are reductive dissolution of iron oxides combined with oxidation of sulfide minerals and organic matter (Michael, 2013; Welch et al., 2000). Arsenic release to groundwater can also occur through desorption via changes in $\mathrm{pH}$, variable concentrations of competitive anions, changes in As speciation, or anthropogenic causes (VanDerwerker et al., 2018). 


\section{Chapter 5: Regional Geology}

North Carolina has three main physiographic provinces: The Blue Ridge, the Piedmont, and the Coastal Plain (Figure 19). Each province is characterized by rock type, sedimentation, tectonic structures, and types of landforms. The Blue Ridge Province is in the most western section of North Carolina and is a mountainous area with numerous steep mountain ridges and trench valleys that interweave to give the area its rugged appearance. This province has an area of approximately 6,000 square miles, about $10 \%$ of the area of the state, and contains the highest elevations in the Appalachian Mountains. Because the Blue Ridge is west of all Mesozoic rift structures, it will be omitted from any further discussions. The boundary between the Blue Ridge and Piedmont provinces is a fault system, the Brevard Fault Zone, and coincides with a significant gravitational anomaly, known as the Appalachian Gravity gradient. This boundary is thought to represent the master detachment fault associated with Triassic crustal thinning and extension and is likely a reactivated over-thrusted package of Paleozoic sedimentary and metamorphic rocks (Guo et al., 2019). The Coastal Plain is furthest east and begins at the Fall Line, where Piedmont rock suites are covered by Cretaceous age coastal sediments and sedimentary rock.

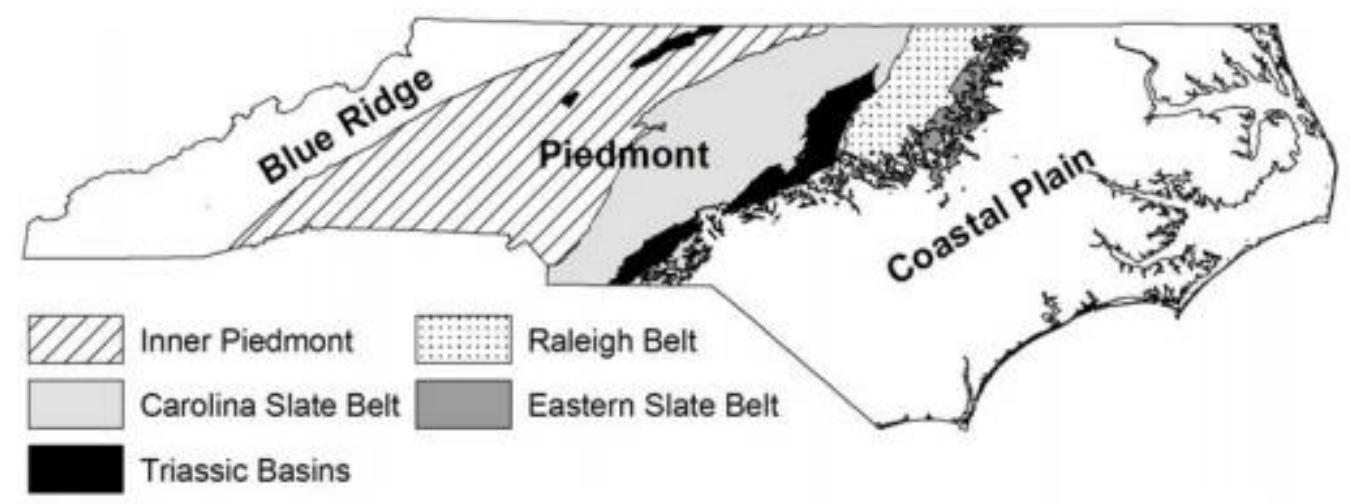

Figure 19: Major geologic regions of North Carolina. (Reid and Milici, 2008) 


\section{The Piedmont}

The Piedmont Province separates the Coastal Plain Province in the east and the Blue Ridge Province in the west and covers about $45 \%$ of the land area in North Carolina. It is characterized by gently rolling foothills and long low ridges with isolated low-lying mountainous areas underlain by Proterozoic and Paleozoic metamorphic and intrusive igneous rocks. The boundary between the western Piedmont and the eastern Piedmont (also known as the Carolina Zone) is a fault system, the central Piedmont shear zone (Hibbard et al, 2002). The Fall Line, the most landward extent of coastal sedimentary onlap, represents the eastern extent of the Piedmont Province and the beginning of the Coastal Plain.

The western Piedmont is dominated by higher-grade gneisses, schists, and amphibolites, while the eastern Piedmont consists primarily of low-grade metavolcanic and metasedimentary rocks. The spatial proximity and similar general stratigraphy suggest they may be related. It is possible, however, that both the western and eastern Piedmont are separate volcanic arcs that have been amalgamated onto the Euramerica Plate during the closure of the proto-Atlantic Ocean. Evidence of regional geologic events is sparse, but terranes within the Piedmont exhibit strong heterogeneity in magmatism, deposition, and tectonothermal overprint (Hibbard et al, 2002). The age of the rocks is inexact but range from Neoproterozoic to early Paleozoic.

The Piedmont can be further divided into lithological regions recognized as various terranes and slate belts, with each having distinguishable lithology and mineral compositions (Figure 20). The boundaries between terranes or belts is often marked by a fault system and/or mylonitized zone signifying zones of weakness where rift basins may initiate formation. The western Piedmont is comprised of four terranes which include the Inner Piedmont, the King's Mountain Belt, the Milton Belt, and the Charlotte Belt. The Danville Basin separates the Inner 
Piedmont from the Milton Belt near the Virginia/North Carolina state line. The Caroline Zone is also comprised of four terranes, termed the Carolina terrane, the Easternmost Carolina terrane, the Spring Hope terrane, and the Roanoke Rapids terrane. The Deep River basin separates the Carolina terrane from the Easternmost Carolina terrane along the Jonesboro Fault system from the central part of the state southward. Both the Nutbrush Creek Fault system and the Hollister Fault zone, terrane-separating fault zones, can be partially traced underneath Coastal Plain sediments. The Roanoke Rapids terrane dips eastward past the Fall Line and makes up a large portion of basement rock underlying the Coastal Plain.

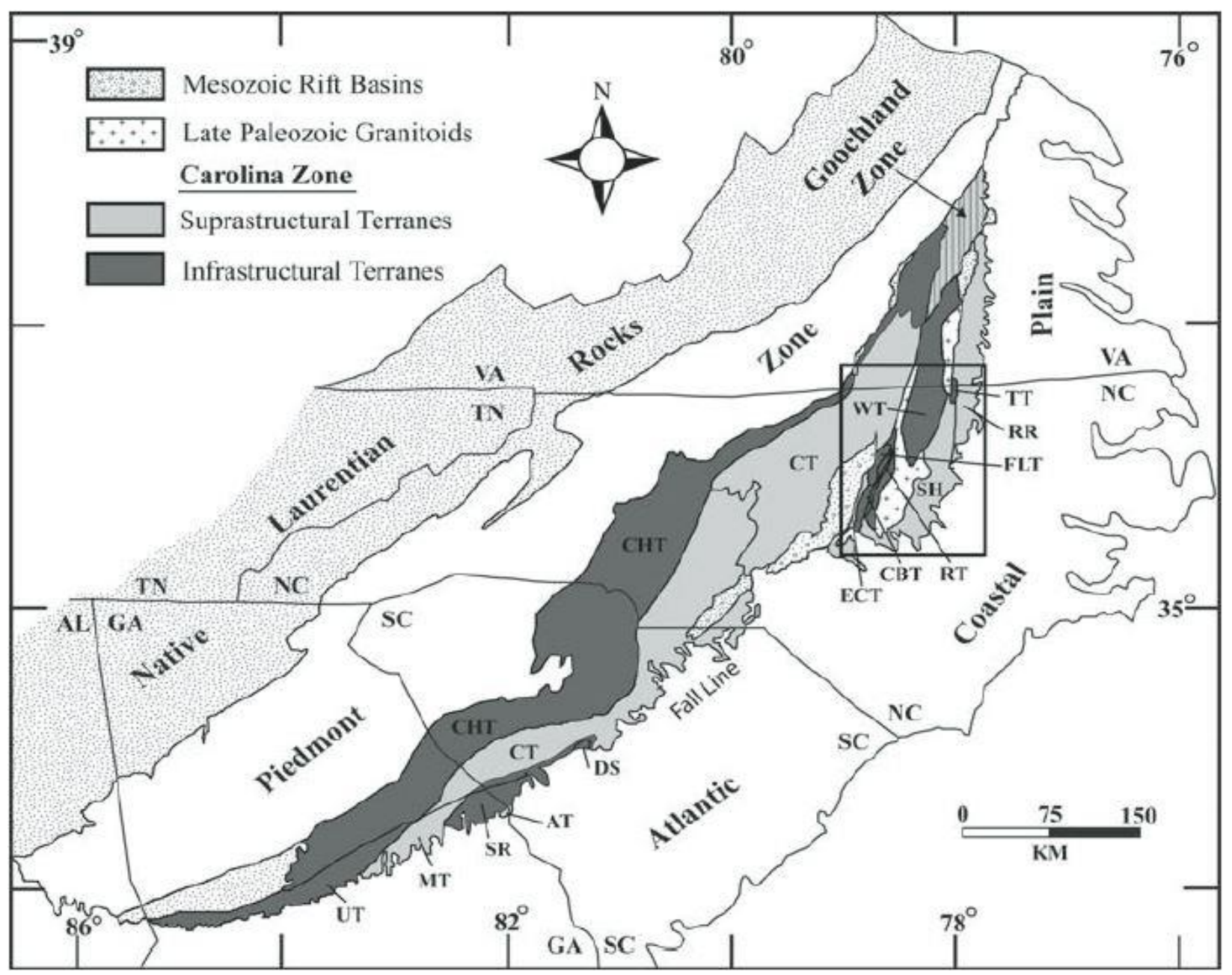

Figure 20: Tectonostratigraphic element map of suprastructural and infrastructural terranes of the Piedmont Suprastructral elements include the Milledgeville (MT), Augusta (AT), Roanoke Rapids (RR), Spring Hope (SH), Carolina (CT), and Easternmost Carolina (ECT) terranes. Infrastructural elements include the Uchee (UT), Savannah River (SR), Dreher Shoals (DS), Falls Lake (FLT), Triplet (TT), Warren (WT), Raleigh (RT), Crabtree (CRT), and Charlotte (CHT) terranes. (Blake et al., 2012) 
The terranes of the Carolina Zone consist of metavolcanic-dominated and metasedimentary units which have undergone low-grade metamorphism and exhibit slaty cleavage, which is why they are generally termed slate belts. Low temperature mineralization from metamorphism include chlorite, epidote, stilpnomelane, and other numerous minerals in smaller amounts (Hibbard et al, 2002). Scarce fossils in some of the Cambrian sedimentary units are exotic to North America and relate more closely to Gondwana fauna and flora suggesting that the Carolina Zone was a peri-Gondwanan volcanic arc. Composition of the igneous rock is calcalkaline which has a strong correlation with subduction type rifting zones. Closure of the protoAtlantic Ocean leading up to the formation of Pangaea supports the genesis of these rocks as a rifting volcanic arc. A series of terranes further north, known as Avalonia, show similar fossils and are known to have been peri-Gondwanan volcanic arcs indicating a similar style of genesis and docking (Hibbard et al, 2002). The amalgamation of the volcanic arc onto the continental mass could also explain a regional metamorphic event and basaltic intrusion that occurred during the Ordovician, 480-450 Ma. (Butler, 1991).

The Carolina Zone is intruded by mid-Paleozoic basalts and Mesozoic rhyolite/andesite dikes, which likely formed during later rifting. Many early Mesozoic tholeiitic dikes that occur in the Piedmont have been radiometrically dated to be approximately $200 \mathrm{Ma}$ and are related to the CAMP event (Sutter, 1988). Mesozoic granitic intrusions cut into many areas and are relatively undeformed, supporting the hypothesis that they intruded after a Paleozoic metamorphic event (Hibbard et al, 2002).

The Carolina Zone includes the broad Deep River basin and two small outliers, the Ellerbe basin in North Carolina and the Crowburg basin in South Carolina. The Inner Piedmont includes the narrow Dan River basin and a small southerly outlier, the Davie County basin. 
(Olsen et al, 1991). The exposed, elongate, Piedmont rift basins are aligned subparallel to the Paleozoic Appalachian orogen and strike northeasterly, mainly across North Carolina. It is postulated that pairs of basins are related to the change in dip of the detachment surface near the Appalachian gravity gradient. Examples are the facing border faults of the Deep River and Dan River basins (Manspeizer, 1981; Hutchinson and Klitgord, 1988).

Many similarities exist between the Deep River and Danville basins, the two largest basins in North Carolina. They are half grabens flanked by major bounding normal-fault zones towards which the basin strata dip (Olsen et al., 1991). Each basin displays an overall tripartite stratigraphy consisting of a lower sequence of mainly reddish-brown, arkosic, coarse-grained sandstone and conglomerate, a middle sequence of mostly gray to black fossiliferous siltstone, carbonaceous shale, and thin coal beds, and an upper sequence of mainly reddish-brown siltstone, arkosic sandstone, pebbly sandstone, minor red and gray mudstone, and conglomerates (Olsen et al, 1991). The Danville and Deep River basins both contain diverse and well-preserved fossils of pollen and spores, macroscopic plants, invertebrates, fish, and tetrapods. Plant spores and pollen mainly form the basis for biostratigraphic correlations that place most of the sedimentary deposits of the basins in the Carnian Stage of the Upper Triassic (Olsen et al, 1991). Also, both basins are intruded by through-going north- and northwest-striking diabase dikes (Olsen et al, 1991).

\section{Deep River Basin}

The Deep River basin is the southernmost of large exposed Mesozoic basins in the Newark Supergroup. It ranges in size from 9 to $25 \mathrm{~km}$ wide and is $240 \mathrm{~km}$ long with a general strike from northeast to southwest. The basin is positioned between Proterozoic and Cambrian metavolcanic and metasedimentary rocks of the Carolina slate belt to the northwest and gneisses, 
schists, and intrusive rocks of the Raleigh slate belt to the northeast (Olsen et al., 1991). It is onlapped by Cretaceous and younger sediments of the Atlantic Coastal Plain to the southeast. The main bounding fault is on the eastern margin and is west-dipping, known as the Jonesboro fault system. The structural architecture of the basin is a half-graben basin with sedimentary rocks that dip southeast towards the Jonesboro fault system (Figure 21).

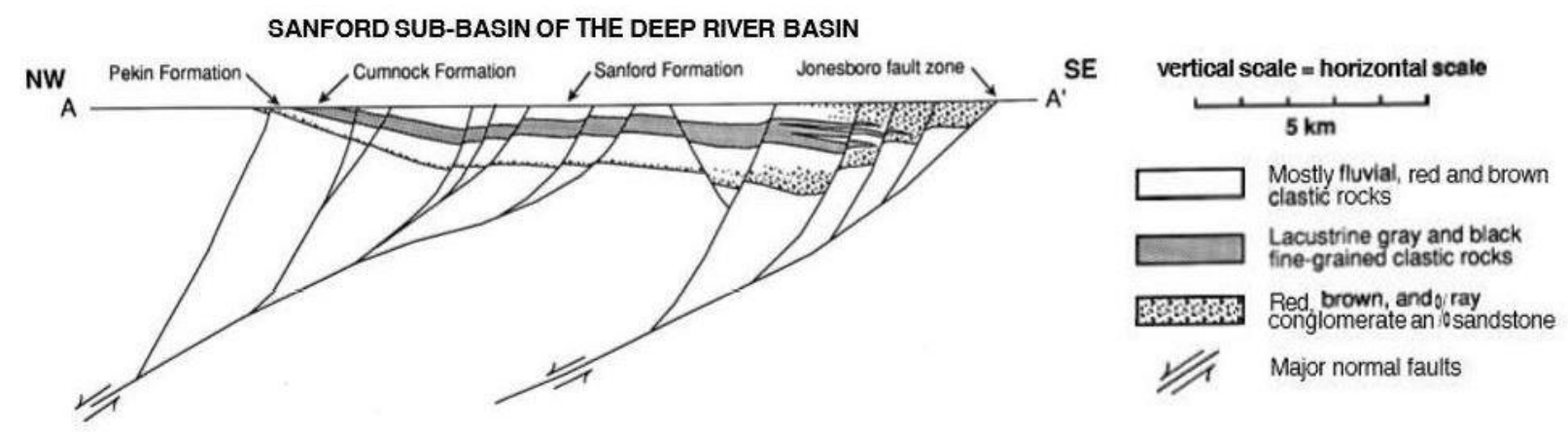

Figure 21: Cross-sectional view of the Deep River basin based on seismic and deep drill hole data. (Olsen et al., 1991)

Three sub-basins, the Durham, Sanford, and Wadesboro sub-basins, comprise the larger Deep River basin (Figure 22). Two sets of faults are defined within the basin. The larger set parallels the Jonesboro fault system comprising both synthetic and antithetic faults cutting the basin into fault blocks that generally duplicate basin margins and sections. This fault set appears to be post-depositional or possibly a series of half grabens of the Jonesboro fault system that experienced syn- and post-rift subsidence (Olsen et al., 1991). The outlying Ellerbe basin is likely a remnant of basin fill over a half graben that has since been uplifted and exhumed. The second fault system strikes northwest to southeast, roughly perpendicular to the major set. In general, these faults are nearly vertical with little displacement compared to the larger fault system. Often, these faults and any parallel dikes within the basin are truncated by the Jonesboro faults system (Bain and Harvey, 1977). 


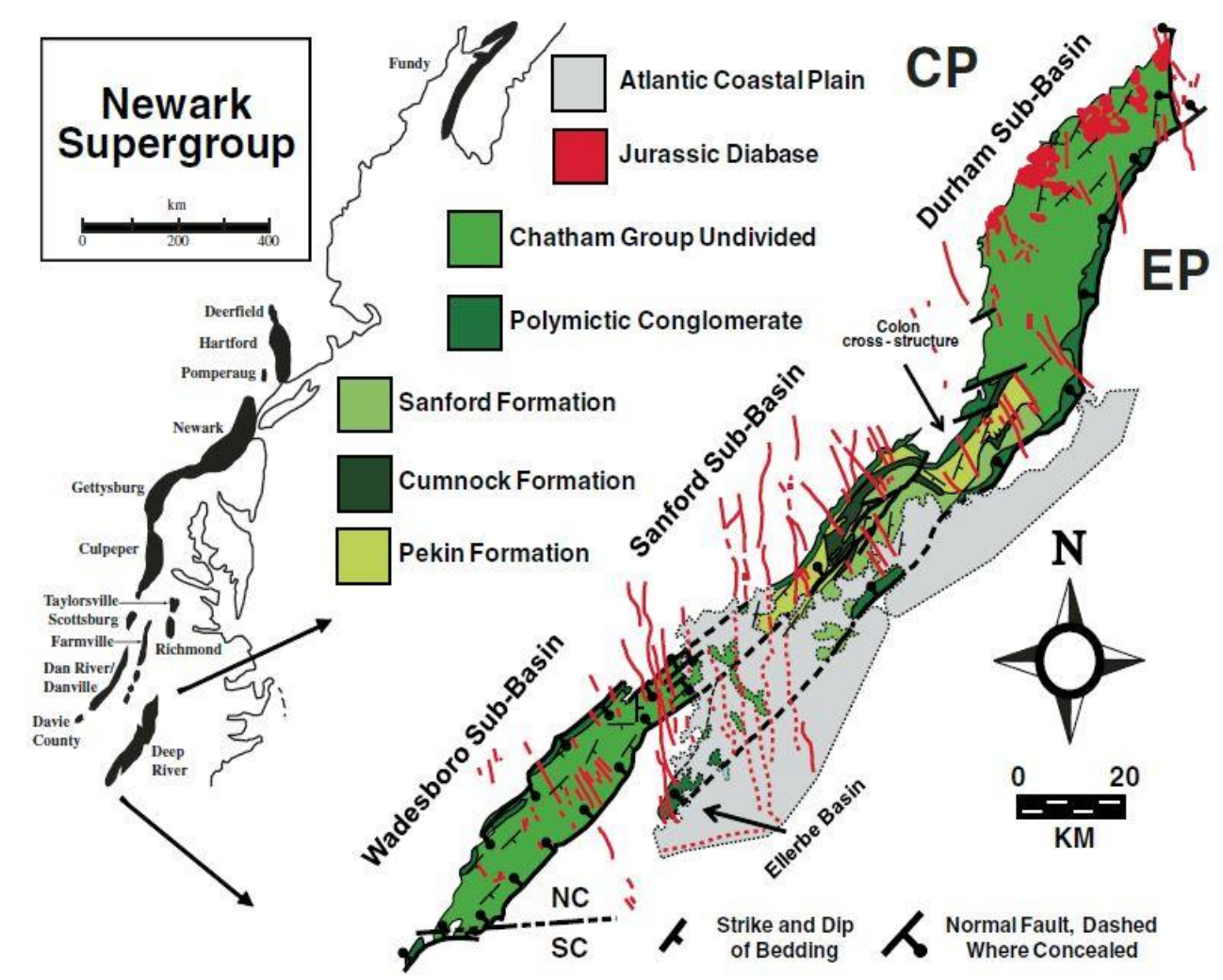

Figure 22: Generalized geologic map of the Deep River basin and sub-basins. Thin red lines are Jurassic diabase dikes. $\mathrm{CP}=$ Central Piedmont, EP = Eastern Piedmont. (Blake et al., 2012)

Triassic sedimentary rocks in the Deep River basin are referred to as the Chatham Group in the Durham and Wadesboro sub-basins but can be divided into three formations in the Sanford sub-basin (Emmons, 1852; Froelich and Olsen, 1984). Formally named by Campbell and Kimball (1923), they are the Pekin, Cumnock, and Sanford formations and consist of upper and lower units of red terrigenous clastic rocks separated by a medial unit of gray to black shale, coal, and sandstone, correspondingly. Lai and others (1985) utilized all available geophysical and subsurface data and confirmed the maximum depth of the Sanford sub-basin is approximately $2 \mathrm{~km}$ deep, strata dip eastwards, and that the eastern flank of the basin is stepped.

The lower part of generalized stratigraphic section, the Pekin formation, is found in all three sub-basins, and consists of a thin, approximately 10 meter, mature basal conglomerate overlain by interbedded sandstones and mudstones mixed with immature conglomerates of local 
provenance. The mature conglomerates are likely related to through-going fluvial environments while the immature conglomerates are likely alluvial fans formed from fault scarps or border faults. Large cross-beds found in gravelly sandstone and silicified or coalified wood and lenses of siltstone also suggest fluvial processes for the mature conglomerates. The rest of the stratigraphic sequence consists of crude fining-upward beds of sandstone with irregular channelform lenses similar to braided stream deposits or distributary channels on deltas that possibly entered small lakes or ponds on a muddy basal plain. Abundant root and burrow traces indicate wet and swampy conditions similar to the climatic environment that is thought to exist for Southern basins. Paleocurrent studies suggest a south to southeasterly direction of water flow in the Durham sub-basin and the larger basin as a whole (Hoffman and Gallagher, 1988). The absence of fluvial intertongues in lacustrine deposits suggest a through-going drainage system in each of the sub-basins (Smoot, 1985).

A lower middle sequence of fine-grained clay-shale and mudstone making up an interval between 50 to $400 \mathrm{~m}$ thick in the Cumnock formation is found in all three sub-basins. Up sequence, a series of coal seams between 1 and $3 \mathrm{~m}$ thick exists (Robbins and Textoris, 1986). These seams are associated with shale, siltstone, and ferruginous shale containing limonite, siderite, ammonium, and phosphate-rich nodules known as "blackband" (Krohn et al., 1988). This coal-bearing interval is overlain by 150 to $170 \mathrm{~m}$ of calcareous and carbon-rich gray and black shale with minor mudstone and sandstone in a coarsening-upward sequence associated with lacustrine environments. The corresponding lake system was likely hydrologically open because stratigraphy does not show well-developed astronomical cycles and an absence of evaporite minerals (Gore, 1989). Orbital cycles are interpreted to be changes in monsoonal climate predominantly controlled by precession (21,000 yrs) and eccentricity (100,000 and 
400,000 yrs) (Olsen, 1986; Olsen et al., 1989). Fossils are abundant and generally reflect lithological changes seen throughout the Van Houten cycles in microlaminated, organic-rich portions of the formation (Olsen et al., 1991). The uppermost part of the sequence is dominated by gray siltstones and sandstones that grade upwards into red and brown terrigenous sandstones of the Sanford formation.

The uppermost part of the stratigraphic sequence, the Sanford formation, consists of repetitive fining-upward sequences of cross-bedded and cross-laminated sandstones with red massive mudstone (Olsen et al., 1991). These deposits suggest a meandering river environment with high-suspension sediment load capacity. Although lower parts of this sequence show some lacustrine deposition, higher exposures consist of only fluvial deposits. Red to brown, coarsegrained, arkosic sandstones and conglomerates dominate the upper $300 \mathrm{~m}$ of the Sanford formation with coarser grain sizes to the southeast, up-section, and towards the border fault (Reinemund, 1955).

Detailed correlation among the three sub-basins is uncertain due to a lack of pollen and spore samples and poor orbital cycling structures within lacustrine rocks of both the Durham and Wadesboro sub-basins. Plant spores and pollen generally place most sedimentary deposits within the Carnian Stage (237-227 Ma) of the Upper Triassic. Lacustrine sequences between the three sub-basins do not appear to be the same age, based on fish, tetrapod, and palynomorph assemblages (Olsen et al., 1982). The oldest sequence found in the Cumnock formation of the Sanford basin dates to the middle Carnian and relates to the middle sequence of clay shales and mudstones of the Wadesboro basin (Cornet and Olsen, 1985). The Durham basin, however, has lacustrine units that date to the late Carnian based on fish and reptile fossils (Olsen et al, 1982). The lower Sanford formation may be laterally equivalent to the middle clay shale and mudstones 
of the Durham sub-basin. Further, the lacustrine Cumnock formation of the Sanford basin could be related to upper part of the lower sandstone sequence in the Durham basin (Olsen et al., 1991). It is possible that lacustrine deposits only began in the Durham and Wadesboro sub-basins after most of the Cumnock formation was already deposited in the Sanford sub-basin.

\section{Danville Basin}

The Danville basin is located in North Carolina and Virginia within the Inner Piedmont province. The Danville basin is approximately $167 \mathrm{~km}$ long with nearly $80 \mathrm{~km}$ of that length in North Carolina designated as the Dan River basin, and ranges from 3 to $15 \mathrm{~km}$ wide. This Newark Supergroup basin is exceptionally long and narrow and bounded on the northwest by a southeast-dipping fault, known as the Chatham fault zone. The fault zone strikes at approximately $\mathrm{N} 30^{\circ} \mathrm{E}$ and dips as much as $45^{\circ}$ towards the SE. Sedimentary rocks within the basin dip moderately to steeply northwest towards the Chatham fault zone in a range of 30 to 65 degrees (Figure 23). High dip angles and stratigraphic offset indicate post-rift inversion has occurred. The southeastern margin of the basin is predominantly an unconformity with the presence of local northwest-dipping normal faults (Thayer, 1970).
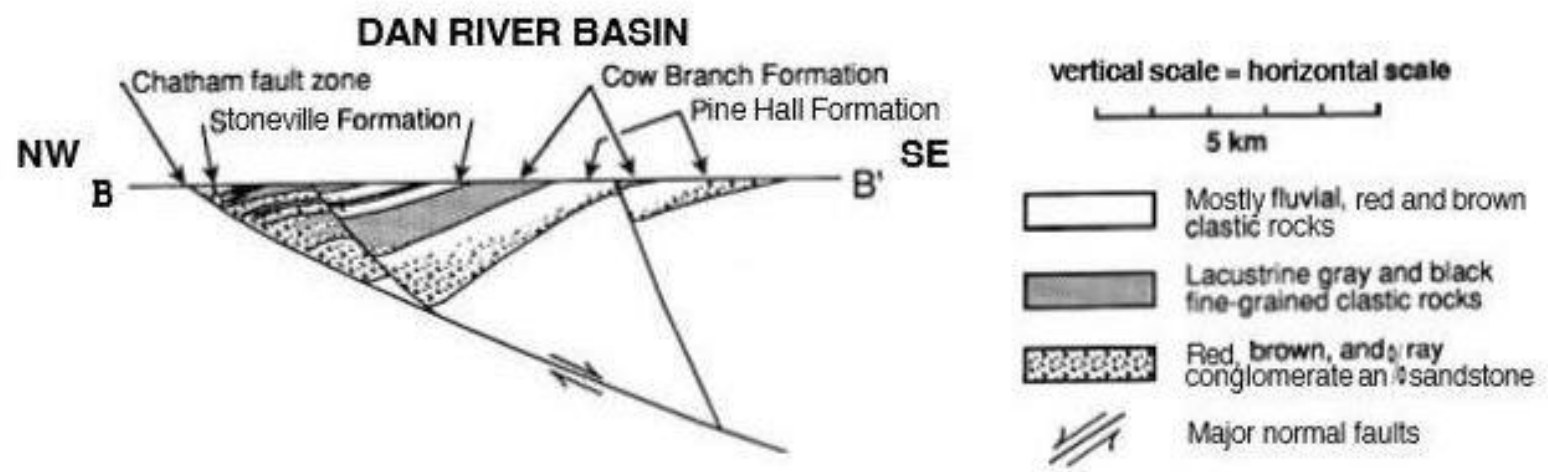

Figure 23: Cross-sectional view of the Danville basin largely based on surface data. (Olsen et al., 1991) 
A tripartite stratigraphy exists within the basin, dividing the Dan River Group into three formal units: The Pine Hall Formation, the Cow Branch Formation, and the Stoneville Formation (in ascending stratigraphic order) (Thayer, 1970). The Pine Hall Formation outcrops along the southeastern margin and is conformably overlain by the Cow Branch Formation. Similarly, the Stoneville formation conformably overlies and interfingers with the Cow Branch-Pine Hall sequence (Thayer, 1970). Maximum thicknesses of sedimentary rocks calculated from gravity data of 8 profiles across-strike to the basin suggest a range of $1450 \mathrm{~m}$ to $1900 \mathrm{~m}$ which may be less in narrower segments and significantly deeper, up to $4000 \mathrm{~m}$, in wider areas (Thayer, 1970).

The lowermost Pine Hall Formation is a predominantly fluvial formation consisting of a basal conglomerate of local provenance overlain by a gray to red, medium- to coarse-grained, pebbly, arkosic sandstone with trough cross-bedding features that passes to massive bioturbated red siltstone and mudstone up-sequence (Thayer, 1970). The upper part of the sequence finesupward and resembles braided river deposits that have undergone extensive diagenesis, recrystallization, and albitization. No fossils have been found in this unit other than burrows, roots, and silicified wood.

The medial Cow Branch Formation consists largely of black and gray cyclically bedded lacustrine deposits of shales, mudstones, and sandstones. Diachronous sedimentation of disjunct beds within this formation is supported by evidence of late Carnian ages near the North Carolina/Virginia border and middle Carnian ages to the south (Olsen et al., 1982; Robbins et al., 1988). Meter-scale alternating laminated and microlaminated calcareous siltstone, claystone, and heavily mudcracked massive mudstone make up typical Van Houten cycles suggest changing lake levels in a hydrologically closed basin (Smoot, 1985; Olsen, 1986; Olsen et al., 1989). The Cow Branch Formation yields some of the oldest known complete insects, including true flies 
and water bugs, among Newark Supergroup basins (Olsen et al., 1991). Thin, non-economical coal seams are also present in the southernmost outcrops of the Cow Branch Formation along the southeast margin of the basin.

The upper Stoneville Formation consists of mostly fluvial red and brown sandstones that border the Chatham fault system to the northwest. Pollen and spore samples date to the early Norian (Olsen et al., 1991). This formation includes rhythmic upward-fining sequences of crossbedded sandstone that passes into ripple cross-laminated sandstone within mudstones associated with meandering river deposits (Thayer, 1970). Lower in the sequence are microlaminated black and gray lacustrine deposits with prominent Van Houten cycles (20,000 yrs), although with far less abundance than the Cow Branch Formation. Also assigned to the Stoneville Formation are coarse clastic strata associated with alluvial or fan delta deposits along the border fault that have a provenance to the oldest rocks west of the Chatham fault system (Thayer, 1970). They consist

of red, gray, and brown, poorly sorted, coarse-grained conglomerates and arkosic sandstone with lenses of matrix-supported clasts with textural and mineralogical changes due to recrystallization, hydrothermal alteration, and albitization (Thayer, 1987).

\section{The Coastal Plain}

The Coastal Plain is generally flat with low-relief hills and valleys which covers nearly $45 \%$ of the land area of North Carolina. The basement surface beneath the Coastal Plain of North Carolina extends from surface outcrops in the west, at the Fall Line, to a maximum drilled depth of 9,854 feet below sea level at Cape Hatteras (Lawrence and Hoffman, 1993). Basement lithologies are concealed by Cretaceous and Cenozoic sediments and must be inferred from well reports and geophysical data, mainly aeromagnetic, gravity, seismic refraction, and seismic 
reflection surveys. Cretaceous and Cenozoic sedimentary cover consists of sandstones, siltstones, and limestones, which comprise a coastal aquifer system.

The basement surface is defined as the base of the Upper Mesozoic to Lower Cretaceous sedimentary section and is commonly referred to as the post-rift unconformity surface. Beneath the southern part of the Coastal Plain, structure contours of the basement surface define a very broad, southeast-plunging positive feature known as the Cape Fear arch. To a lesser degree, the Norfolk arch (Fort Monroe high), which approximately coincides with the Virginia-North Carolina State border, is apparent from the -2,000-foot and deeper contours (Lawrence and Hoffman, 1993). The intervening area of deeper basement and thicker sedimentary section between these two features is known as the Albemarle embayment. The most prominent paleotopographic feature is the granitic monadnock, a Paleozoic pluton, which rises $350 \mathrm{ft}$ above surrounding basement and crops out at an elevation of approximately 90 feet above sea level near Fountain, Pitt County (Lawrence and Hoffman, 1993). Paleotopographic highs of basement rock also crop out in several locations within the Coastal Plain in both Johnston and Harnett Counties and an area west of Goldsboro (Lawrence and Hoffman, 1993).

Cuttings and cores from 124 boreholes to basement, combined with Bouguer gravity and magnetic maps, allowed Lawrence and Hoffman (1993) to construct an interpretive geologic map, a structure contour map of the basement surface, and a map of metamorphic grade (Figure 24). More than 75 wells that recovered samples of phyllite, schist, gneiss, granite, diorite, etc. from beneath Coastal Plain sediments (Daniels and Leo, 1985; Daniels and Zietz, 1978) help define the distribution of "crystalline" basement and thereby constrain the extent of sub-surface Mesozoic basins (Olsen et al, 1991). Because of the predominance of low-grade metavolcanic rocks in the subsurface directly adjacent to similar rocks along the margin of the Piedmont, it is 
probable that a large, continuous, low-grade Avalonia terrane, with similar diagenesis to the slate belts in the Piedmont, underlies large extents of the Coastal Plain of North Carolina and eastern South Carolina (Williams and Hatcher, 1982). The seaward extent of the slate belts that constitute basement underneath the Coastal Plain is poorly constrained, however. 


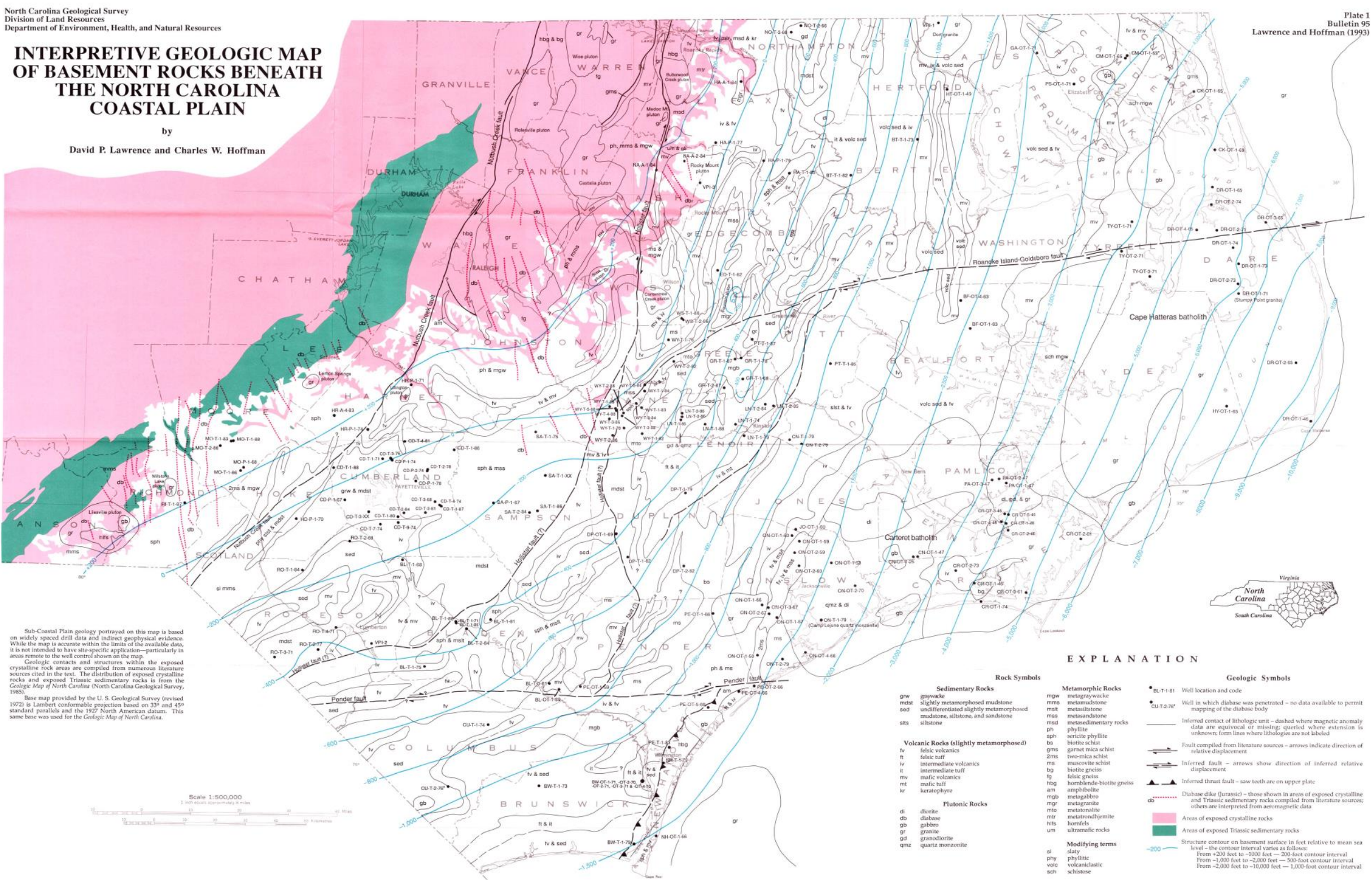

Figure 24: Interpretive geologic map of basement rocks beneath the North Carolina Coastal Plain showing structure contours, faults, lithology, and magnetic anomalies. (Lawrence and Hoffman, 1993) 
Lawrence and Hoffman (1993) used lithologic characteristics and tectonic features of basement rocks in the Coastal Plain and grouped them into five major regions (Figure 25) that generally coincide with several terranes named by Horton and others $(1989,1991)$. They are the Carolina terrane, Spring Hope terrane, Charleston terrane, Roanoke Rapids terrane, and the Hatteras belt. The Carolina terrane and Spring Hope terrane have been described previously, as they make up the Carolina Zone of the eastern Piedmont. Both, however, are partially covered by Coastal Plain onlap and comprise portions of the basement rock eastward of the Fall Line.

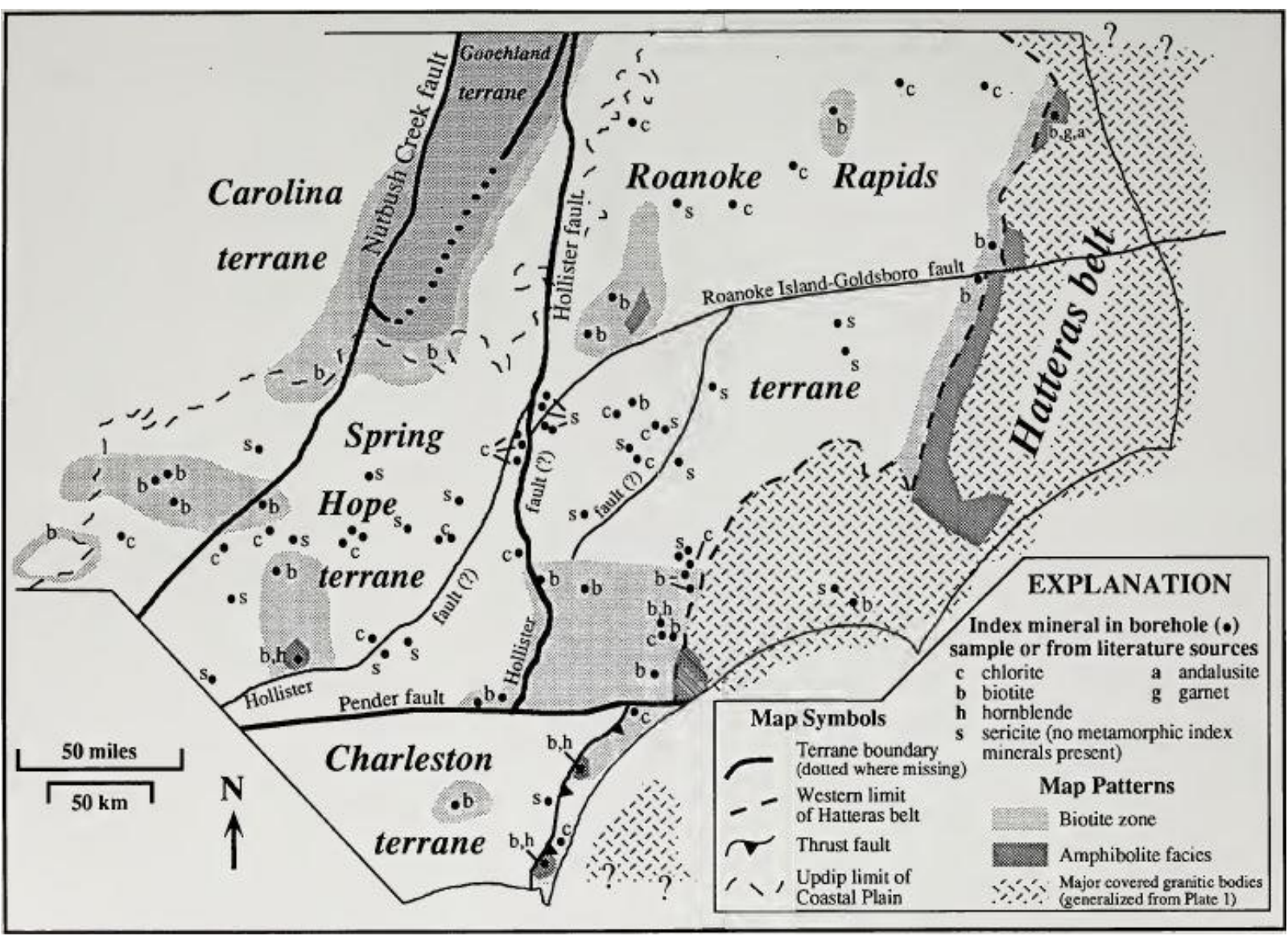

Figure 25: Interpretive map of terrane boundaries, faults, and metamorphic grade of crystalline basement rock beneath the North Carolina Coastal Plain. (Lawrence and Hoffman, 1993)

Five major faults have been inferred to underlie Coastal Plain cover. Two late Paleozoic fault zones that crop out in the Piedmont, the Nutbush Creek and the Hollister, are mappable as magnetic lineaments to the south under the Coastal Plain sediments and sedimentary rock. Two 
east-trending faults are inferred to intersect the Hollister fault in the Coastal Plain basement, the Roanoke Island-Goldsboro fault and the Pender fault, the latter of which separates the Roanoke Rapids terrane from the Charleston terrane. A possible unnamed fifth fault that generally runs north-south on trend with a 110-km-long magnetic unit thru Pitt, Lenoir, and Duplin counties lies on a boundary between positive linear magnetic anomalies on the west and low magnetic relief on the east interpreted, respectively, as volcanic-rich and-poor rock suites (Sampair, 1979). The recognition and delineation of faults or fault systems within the Coastal Plain basement will improve understanding of the tectonic and geologic history of the continental margin and might provide a better understanding of factors that controlled deposition and subsequent faulting in the overlying sedimentary section (Lawrence and Hoffman, 1993). The overlying sedimentary rocks host and control movement of the groundwater of the Coastal Plain region and the presence and location of major discontinuities is important (Lawrence and Hoffman, 1993).

The Charleston terrane is the southernmost portion of the Coastal Plain basement located south of the inferred east-west running Pender fault system. Magnetic trends are east-west to northeast-southwest with anomalies indicating basement rock comprised of metasedimentary and felsic metavolcanics (Lawrence and Hoffman, 1993). Cores recovered from the area show quartzite and phyllitic fine-grained mica, metamudstone, and altered mafic volcanic rocks. A single large mass of metabasalt or metagabbro is interpreted from a magnetic anomaly in the center of the terrane. Well CU-T-2-76 recovered medium-grained (1-2 mm crystal diameter) diabase that may be attributed to Jurassic intrusives (Lawrence and Hoffman, 1993). On the eastern edge of the Charleston terrane is an area with amphibolite facies, hornblende-bearing rocks and greenschist grade metavolcanics. This area has been interpreted as a higher-grade slate belt near the coast (Daniels and Leo, 1985) or as part of the adjacent higher-grade Hatteras 
terrane (Horton et al., 1989). A large gravitational anomaly, $-50 \mathrm{mGal}$, offshore of Cape Fear that aligns with similar features to the north suggests a batholith in the subsurface of the region (Hutchinson et al., 1982).

The Roanoke Rapids terrane comprises most of the Coastal Plain basement and extends from north of the Virginia state line to the inferred Pender Fault system in the south. It is bordered on the west by the Spring Hope terrane, separated by the Hollister fault system, and on the east by the Hatteras terrane. Magnetic anomalies just east of the Hollister fault resemble those found in the Carolina slate belts in the eastern Piedmont and similar geologic sections are inferred. Layered rocks between the Hollister fault zone and a north-south line that approximately runs through Greenville, NC, are predominantly felsic to mafic volcanic rocks with minor metamudstone, metasiltsone, and volcaniclastic metasandstones (Lawrence and Hoffman, 1993). In a belt east of this line, the opposite is true with compositions of predominantly metamudstones and metasiltstones with minor metavolcanics rocks. This boundary between volcanic-rich and volcanic-poor rock suites has previously been interpreted as a Triassic basin (Daniels and Zietz, 1978) or a possible fault (Daniels and Leo, 1985).

East of a north-south trending line running through central Bertie County, basement rock consists of wide bands of low magnetic relief interspersed with narrow bands of highly magnetic rocks. Elongate positive gravity anomalies of approximately $20 \mathrm{mGal}$ are assumed to indicate possible belts of mafic volcanics. This area has been interpreted as metamorphosed sedimentary rocks and felsic volcanics with narrow bands of mafic metavolcanics rocks (Lawrence and Hoffman, 1993). A pattern of truncated magnetic anomalies that runs east-west under Roanoke Island, Greenville, and Goldsboro suggests a fault within the area, informally named the Roanoke Island-Goldsboro fault (Lawrence and Hoffman, 1993). 
Underlying the coastal counties from the Virginia line south to Onslow County and offshore along the entire coast to south of Wilmington is the Hatteras terrane, which includes two large composite batholiths informally named the Cape Hatteras and Carteret batholiths. The Cape Hatteras batholith is primarily granite, intruded by gabbroic plutons. The Carteret batholith contains diorite, granodiorite, and granite. The majority of plutonic rocks within the Hatteras terrane yield isotopic ages between 580 to $630 \mathrm{Ma}$, late Precambrian to Cambrian (Lawrence and Hoffman, 1993). Scattered ages within the Ordovician, Devonian, and Mississippian suggest shearing and plutonism in the middle to late Paleozoic. A pluton in Suffolk, Virginia, at the northern end of the Hatteras terrane has a crystallization age of $262+/-25 \mathrm{Ma}$ (Russell et al., 1985) similar to uplift and cooling ages elsewhere in the easternmost Piedmont (Mauger et al., 1987). Marginal to the batholiths in the Hatteras terrane are schists and gneisses of lower amphibolite facies (Denison et al., 1967). Biotite-garnet bearing rocks lie west of the Cape Hatteras batholith, and a wider band of biotite-muscovite-bearing schists lie west of the Carteret batholith (Daniels and Leo, 1985; Horton et al., 1989). Higher metamorphic grade within the Hatteras terrane than in either the Piedmont or other areas of the Coastal Plain make the region easily differentiated. Secor and others (1990) suggested the batholithic area may be of Gondwanan origin. The limited extent of the Hatteras terrane to the north and south and possibly related tectonic events within the Pan African belt may support the idea that the terrane is a Gondwanan crustal fragment (Dallmeyer, 1989). Because there is no known fault system separating the Roanoke Rapids terrane from the Hatteras terrane, it is unknown how much of the Coastal Plain basement rock might be included as a Gondwanan fragment.

The Cape Hatteras granite batholith is marked by a $40 \mathrm{mGal}$ negative gravity anomaly and underlies an area of $11,500 \mathrm{~km}^{2}$. Watkins and others (1985) termed the anomaly the 
Albemarle Sound Gravity Anomaly and modelled it as a $10 \mathrm{~km}$ thick pluton, but others have interpreted it as significantly smaller or as several disconnected plutons (Daniels and Leo, 1985; Thomas et al., 1989). In general, the gravity data are spaced so far apart, and the basement is so deep, that smaller units cannot be resolved. Generally, the magnetic signature is flat for the Cape Hatteras batholith apart from two large magnetic highs flanking the west and south sides inferred to be mafic plutons (Lawrence and Hoffman, 1993).

The informally named Carteret batholith has a composition of gabbro-diorite-quartz monzonite-granite. It underlies approximately $7,000 \mathrm{~km}^{2}$ in the southeastern Coastal Plain along the coast. The Carteret batholith has a different geophysical expression than the Cape Hatteras batholith. Several small gravity anomalies underlie the region, a $25 \mathrm{mGal}$ low in the west and 15 mGal high in the east. Magnetic anomalies produce several bands about $13 \mathrm{~km}$ across with 300 gamma highs and 200 gamma lows (Lawrence and Hoffman, 1993). The significantly lower gravity expression of the batholith may be caused by its more intermediate composition and similarity to the host rocks in the region. Other interpretations have included a thinner pluton (Thomas et al., 1989) or a region of smaller plutons and metamorphic rock (Daniels and Leo, 1985).

Mesozoic rift basins beneath Coastal Plain deposits are widely distributed in the eastern Carolinas and offshore (Olsen et al, 1991). These buried basins may be more completely preserved than exposed basins in the Piedmont because of limited exposure to erosion after rifting ceased, and because some were protected by erosionally resistant basalt flows. Buried basins have been inferred based on geophysical data by Bonini and Woollard (1960), Behrendt and Klitgord (1979), Chowns and Williams (1983), and Hutchinson and others (1983) but have not been proved by drilling (Olsen et al, 1991). 
Richards (1954) reported several thousand feet of Triassic rocks drilled in Camden County, and interpreted the presence of a buried Triassic rift basin beneath the northeastern North Carolina Coastal Plain, supported by reports of red sandstone, siltstone, and olivine diabase in a neighboring Pasquotank County well. Olsen and others (1991) informally named it the Elizabeth City basin, which can now be seen on many geologic maps. Reinterpretation of the data by Lawrence and Hoffman (1993) suggests the reddish sediments can be correlated downdip with Coastal Plain sedimentary units rather than the presence of a rift basin. Overall, estimates of the number and size of subsurface basins beneath the Coastal Plain is conservative. Many areas remain devoid of deep well data, however, and for areas with well data, age control is poor due to the lack of fossil evidence.

\section{Offshore}

Offshore seismic surveys have identified numerous basins (Hutchinson and others, 1982; Benson, 1984). Brown and others (1972) reported shale and feldspathic sandstone (their unit I) from 9,145 to 9,853 feet in the Hatteras Light well (DROT-1-46), which they provisionally judged to be Late Jurassic in age. Based on geophysical data Manspeizer and Cousminer (1988) indicate the possibility of an early Mesozoic rift basin at Cape Hatteras, as well as one just offshore of Albermarle sound. Klitgord and others (1988) interpret an early Mesozoic basin on U.S. Geological Survey seismic line 32 just offshore of Cape Hatteras and include the 800 feet of sandstone above basement in DR-OT-1-46 as part of the sedimentary section in the basin.

Without age data on the basal Hatteras well sediments and without a seismic tie from the well to the offshore data, assignment of these beds to an early Mesozoic rift basin depositional setting remains speculative. 
The most significant feature of the gravity field off North Carolina's coast is a $670 \mathrm{~km}$ long anomaly consisting of a gravitational high with flanking lows offshore which runs alongstrike to the NA rift margin and is interpreted as a hinge zone of crystalline basement rock. Landward of the hinge zone is the Carolina platform, consisting of continental crust thought to have only thinned and stretched slightly during rifting. Seaward of the hinge zone, basement dips steeply and is lost beneath a strong reflector, the post-rift unconformity at a depth of about 12 $\mathrm{km}$, forming a deep sedimentary basin referred to as the Carolina trough. In 1985 the United States Geological Survey (USGS), the Naval Oceanographic Research Development Agency and the Scripps Institution of Oceanography cooperated in an experiment to collect large-offset data in the region of the Carolina trough using ocean bottom seismometers as receivers and explosives as sources. Figure 26 is a cross-sectional view of the Carolina Trough and overlying Coastal Plain sediments. Formed because of tectonic and thermal subsidence of thinned and rifted crust, the Carolina Trough is oriented parallel to the NA rift margin without complications induced by oblique or transform fault motion (Klitgord and Behrendt, 1979; Hutchinson et al., 1983). The geometry at the Carolina Trough reflects segmentation along the margin, terminating to the north at the Baltimore Canyon trough and to the south at the edge of the Blake plateau (Trehu et al., 1989). In the region of the Carolina Trough the hinge zone is coincident with the Brunswick Magnetic Anomaly, that has been variously interpreted to represent a rift graben (Hutchinson et al., 1983), the suture between Laurentia and Gondwana (Nelson et al., 1985a, b), or some combination of the two (Klitgord et al., 1988). 


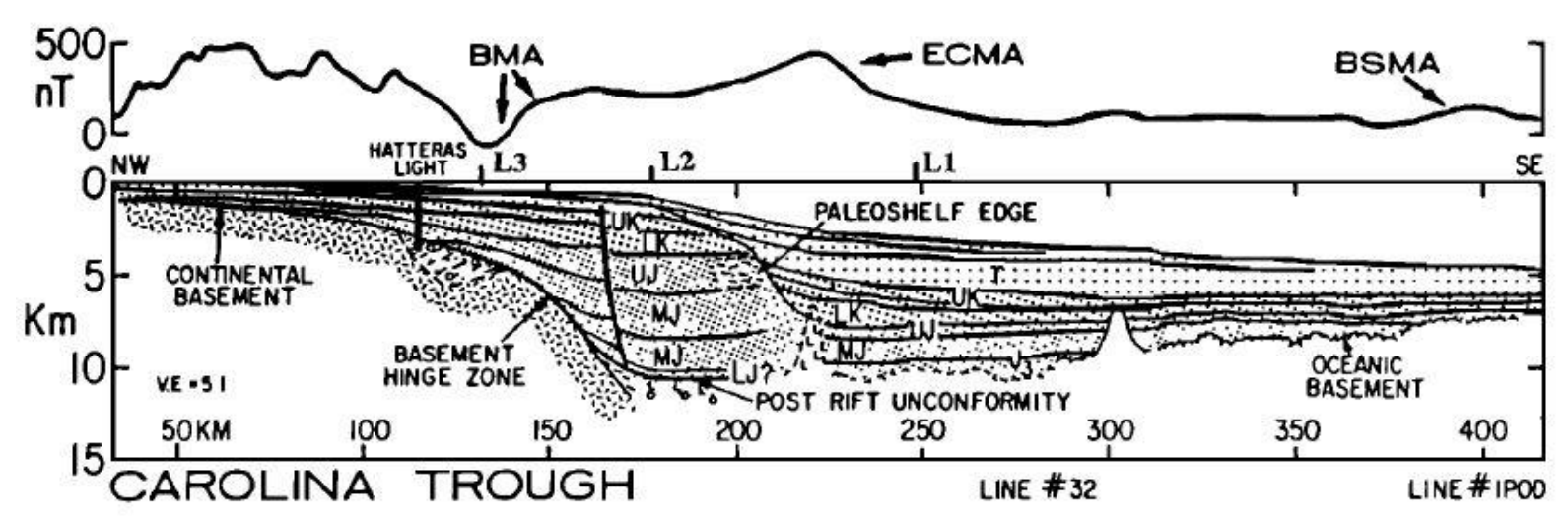

Figure 26: Cross-sectional view of continental basement rock, the Carolina Trough, and Cenozoic Coastal Plain cover T: Tertiary; UK, LK: Upper and Lower Cretaceous; UJ, MJ, LJ: Upper, Middle, and Lower Jurassic; BSMA: Blake Spur Magnetic Anomaly; ECMA: East Coast Magnetic Anomaly; and BMA: Brunswick Magnetic Anomaly. Salt is shown by an "L" pattern. (Trehu et al., 1989)

Gravity anomalies, salt diapirs, and seaward dipping reflectors (SDR's) and their limited extents along the margin support the idea that continental rifting events are often accompanied by generation of large amounts of melt. Further, termination of a gravitational anomaly, likely the displaced Moho, underneath the Carolina trough to the north and south suggests magmatism may be segmented along-strike to the margin (Wyers and Watts, 2006). The origin of segmentation remains unresolved, however, but can be partly attributed to strength variation in rifted lithosphere, strain-softening due to igneous intrusives, diachronous sea-floor spreading, and post-rift sediment loading. Near the ECMA, a magnetic anomaly marking the seaward extent of rift stage crust, basement rock is obscured by a zone of salt diapirs. Despite this, seaward dipping reflectors have been tentatively identified that cross the edge of the southern Carolina trough (Klitgord, 1988; Mutter et al., 1985). These SDR's formed through subaerial volcanism during the late stage of rifting and correlate with a region of the rift margin where lower crustal P-wave velocities are high and the seismic Moho is significantly deeper than calculations from extensional models suggesting that magmatic material has underplated and intruded into the crust (Wyers and Watts, 2006). This thick lens of underplated material extends beneath the Carolina trough and adjacent ocean basin but is either very thin or absent landward of the hinge zone. The 
underplated material reaches a maximum thickness of $13 \mathrm{~km}$ beneath the deepest part of the trough and thins to $5 \mathrm{~km}$ seaward of the ECMA (Trehu et al., 1989). Gravity modeling suggests that total continental crustal thicknesses reach $38 \mathrm{~km}$ near Cape Fear and $40 \mathrm{~km}$ under Pamlico Sound (Hutchinson et al., 1982). 


\section{Chapter 6: Study Site/ Hope plantation}

The Hope Plantation test hole (BE-110-2004) in Bertie County, North Carolina, was cored on the property of the Hope Plantation west of Windsor, North Carolina, by the U.S Geologic Survey (USGS) in conjunction with the North Carolina Geological Survey (NCGS) and the Raleigh Water Resources Discipline (WRD) in March and April, 2004 (Weems et al., 2007). The drill site is located on the Republican 7.5 minute quadrangle at latitude $36^{\circ} 01^{\prime} 58^{\prime \prime} \mathrm{N}$, longitude $78^{\circ} 01^{\prime} 09^{\prime \prime} \mathrm{W}$ (decimal degrees 36.0329 and 77.0192) with an altitude of $48 \mathrm{ft}$ above mean sea level. This test hole was continuously cored by Eugene F. Cobbs, III and Kevin C. McKinney (USGS) to a total depth of $1094.5 \mathrm{ft}$. Upper Triassic, Lower Cretaceous, Upper Cretaceous, and Cenozoic sediments were recovered from the site.

The stated goal of the Hope Plantation project was to collect a lithostratigraphic summary, along with geophysical logs, site core photographs, calcareous nannofossil biostratigraphy, and initial hydrogeologic interpretations. The Triassic material is stated to range from a depth of $1026 \mathrm{ft}$ to $1094.5 \mathrm{ft}$, however this interval is poorly constrained as there is no definitive transition from the Cretaceous to the Triassic (Weems et al., 2007). The presence of at least $70 \mathrm{ft}$ of Triassic strata suggest the presence of a concealed Mesozoic rift basin. Crystalline basement rock was not reached, leaving the overall depth of the basin undetermined. Much is still unknown about this concealed basin concerning its geometry/size, petrology, and geophysical properties.

The USGS open-file report contains descriptions of core recovered from well BE-1102004 (Figure 27). Shifts in both gamma and resistivity logs at a depth of $1026 \mathrm{ft}$ are attributed to a major change in lithology. Core taken from below $1026 \mathrm{ft}$ ranges from angular to sub-rounded 
conglomerate, very coarse to fine quartz sandstone, and clayey siltstone. A dark red to brown ferruginous matrix is abundant. Clast mineralogy descriptions vary from chloritic, schistose quartz, ferruginous sandstone, and diabase. Cores are now stored at the NCGS Raleigh Field Office and Repository.

For this project, previous datasets have been derived from analysis of the cores at the NCGS by Ryan Poythress (unpublished), and include thin sections, whole rock geochemical analysis, and magnetic susceptibility. Although the cores contain less than $100 \mathrm{ft}$ of Triassic strata, these datasets can be used to constrain depositional history, provenance, tectonic facies, and mineral content of the Bertie basin. Interpretation of the data suggests the Triassic strata are derived from a continental island arc which has undergone an orogenic event. 


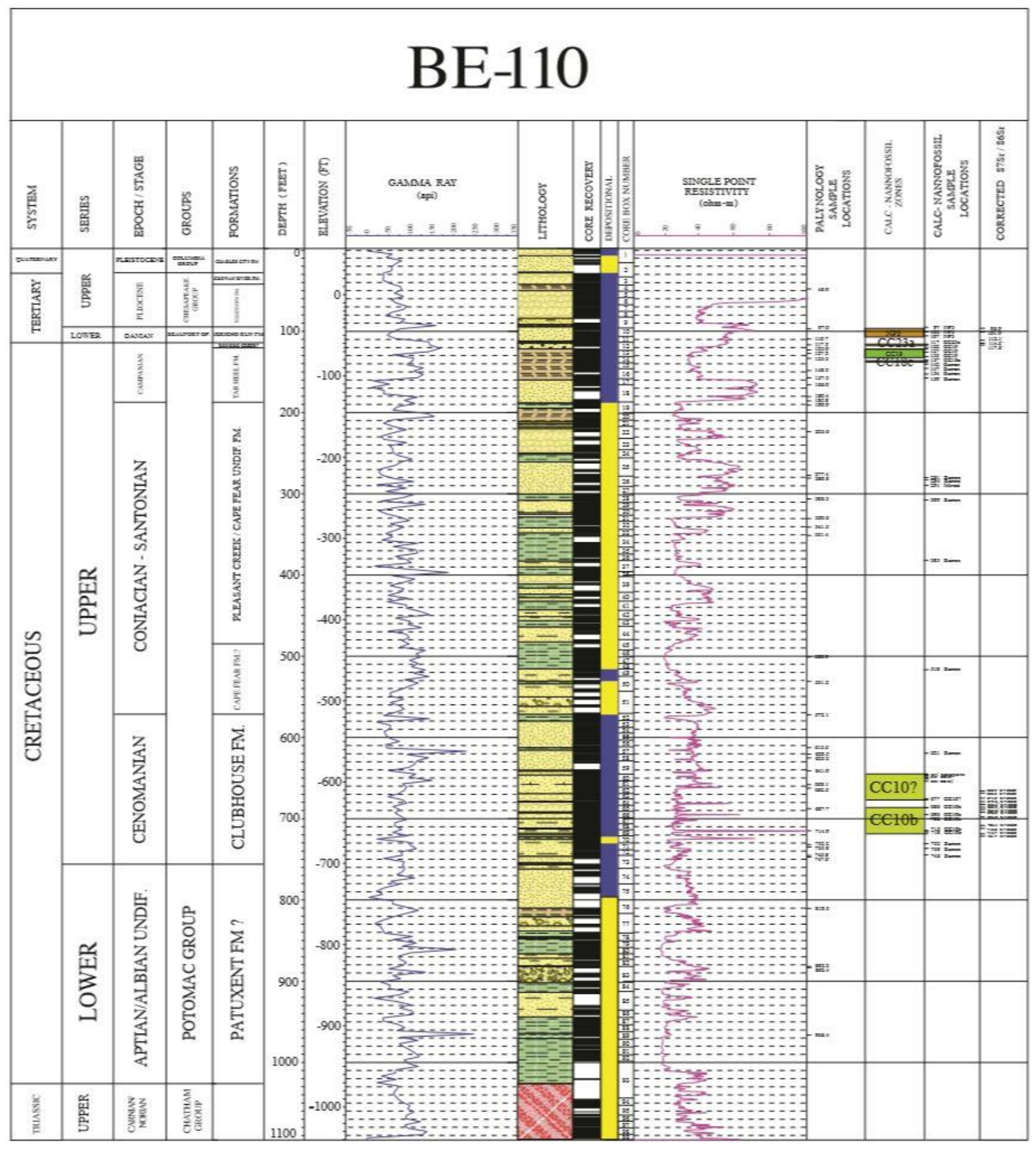

\section{Explanation}

\begin{tabular}{|c|c|c|c|c|c|c|c|}
\hline Fin & Clayey Silt & $\because \because$ & Clayey Sand & \begin{tabular}{ll}
$\because$ \\
$\because \because$ \\
\hdashline
\end{tabular} & Calcareous Sand & एo: & Gravel \\
\hline \begin{tabular}{|l}
$\cdots \cdots$ \\
$\cdots \cdots \cdots$ \\
\end{tabular} & Sandy Clay & & Silty Sand & & Glauconitic Sand & 2010 & Lag Deposit \\
\hline$=$ & $\begin{array}{l}\text { Interbedded } \\
\text { Clay and Sand }\end{array}$ & & Sand & $\therefore 9$ & $\begin{array}{l}\text { Clayey Sand } \\
\text { and Gravel }\end{array}$ & & Redbeds \\
\hline
\end{tabular}

Figure 27: Core log of well BE-110-2004 showing the correlation between lithology and geophysical data. Triassic strata were reached at a depth of $1026 \mathrm{ft}$. (Weems et al., 2007) 


\section{Thin Sections}

Eighteen samples were taken at various intervals from $1026 \mathrm{ft}$ to the end of core at approximately $1096 \mathrm{ft}$. Commercial, 300-point per slide, thin sections analysis from core samples of well BE-110-2004 show the material is rich in quartz and lithic fragments, with rare plagioclase and potassium feldspar (Poythress R., unpublished). Petrography can offer clues relating to depositional history, along with diagenetic alteration of sediments. Dickinson et al. (1983) studied NA Phanerozoic terrigenous sandstones, and variations in their provenance with respect to their tectonic setting. Using ternary diagrams with quartz, feldspar, and lithic fragments as apices, sandstones may be classified into three main classes of tectonic setting. These settings are magmatic arcs, continental blocks, and recycled orogens (Figure 28). Results suggest the recovered Triassic strata have a provenance of recycled orogenic material.
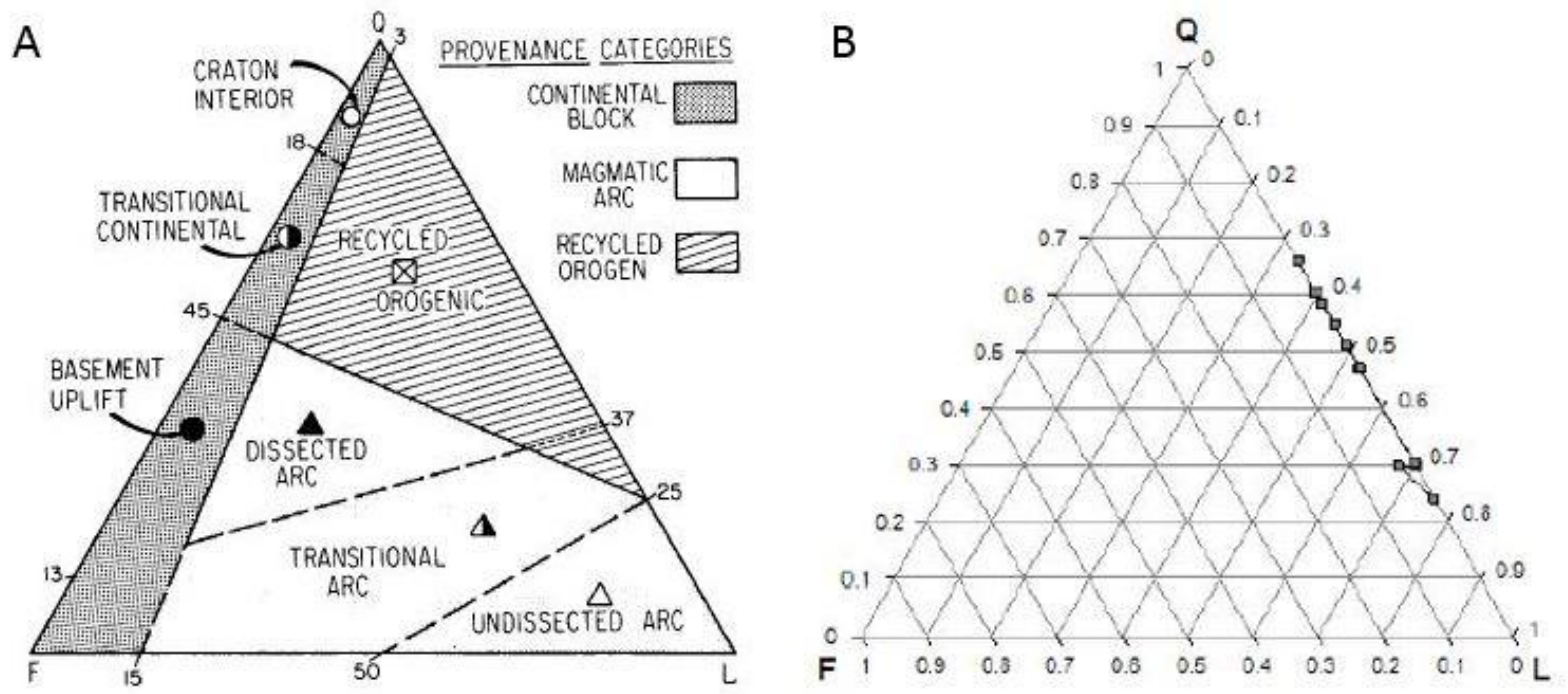

Figure 28: A) Ternary diagram of terrigenous sandstones (Dickinson et al., 1983). B) Ternary diagram of thin section samples from well BE-110-2004 (Poythress R., unpublished) relating tectonic setting and provenance.

\section{Geochemical Analysis}

After petrographic analysis, leftover material consisting of six whole rock samples with two duplicates were sent to Acme Labs for whole rock and trace element geochemical analysis. 
Residue of a predominantly organic epoxy used during thin section preparation may have remained on the samples. The potential for a metal binding agent within the epoxy may have altered the geochemical analysis, but if present would only be found in trace quantities. The results of the geochemical analysis can be found in Appendix C.

Bhatia and Crook (1986) examined bulk and immobile trace elements (e.g. La, Ce, Nd, $\mathrm{Th}, \mathrm{Zr}, \mathrm{Nb}, \mathrm{Y}, \mathrm{Sc}, \mathrm{Co}$ ) in Paleozoic graywackes with regards to geochemical provenance. Using the amount and ratios of these elements, interpretations were made with respect to tectonic setting of the depositional environment. In general, they note an increase in light rare earth elements ( $\mathrm{La}, \mathrm{Ce}, \mathrm{Nd}$ ) and the $\mathrm{Ba} / \mathrm{Sr}, \mathrm{Rb} / \mathrm{Sr}, \mathrm{La} / \mathrm{Y}$ and $\mathrm{Ni} / \mathrm{Co}$ ratios in the graywackes from oceanic island arc to continental island arc to active continental and passive margin settings. Conversely, a decrease is observed in $\mathrm{V}, \mathrm{Sc}$, and the $\mathrm{Ba} / \mathrm{Rb}, \mathrm{K} / \mathrm{Th}$, and $\mathrm{K} / \mathrm{U}$ ratios in the same tectonic settings, respectively. They conclude that the most useful discriminations are gleaned from the La-Th, La-Th-Sc, Ti/Zr-La/Sc, La/Y-Sc/Cr, Th-Sc-Zr/10 and Th-Co-Zr/10 plots. Comparison of Bhatia and Crook's (1986) geochemical tectonic facies with whole rock samples from well BE-110-2004 can be seen in Figure 29. 


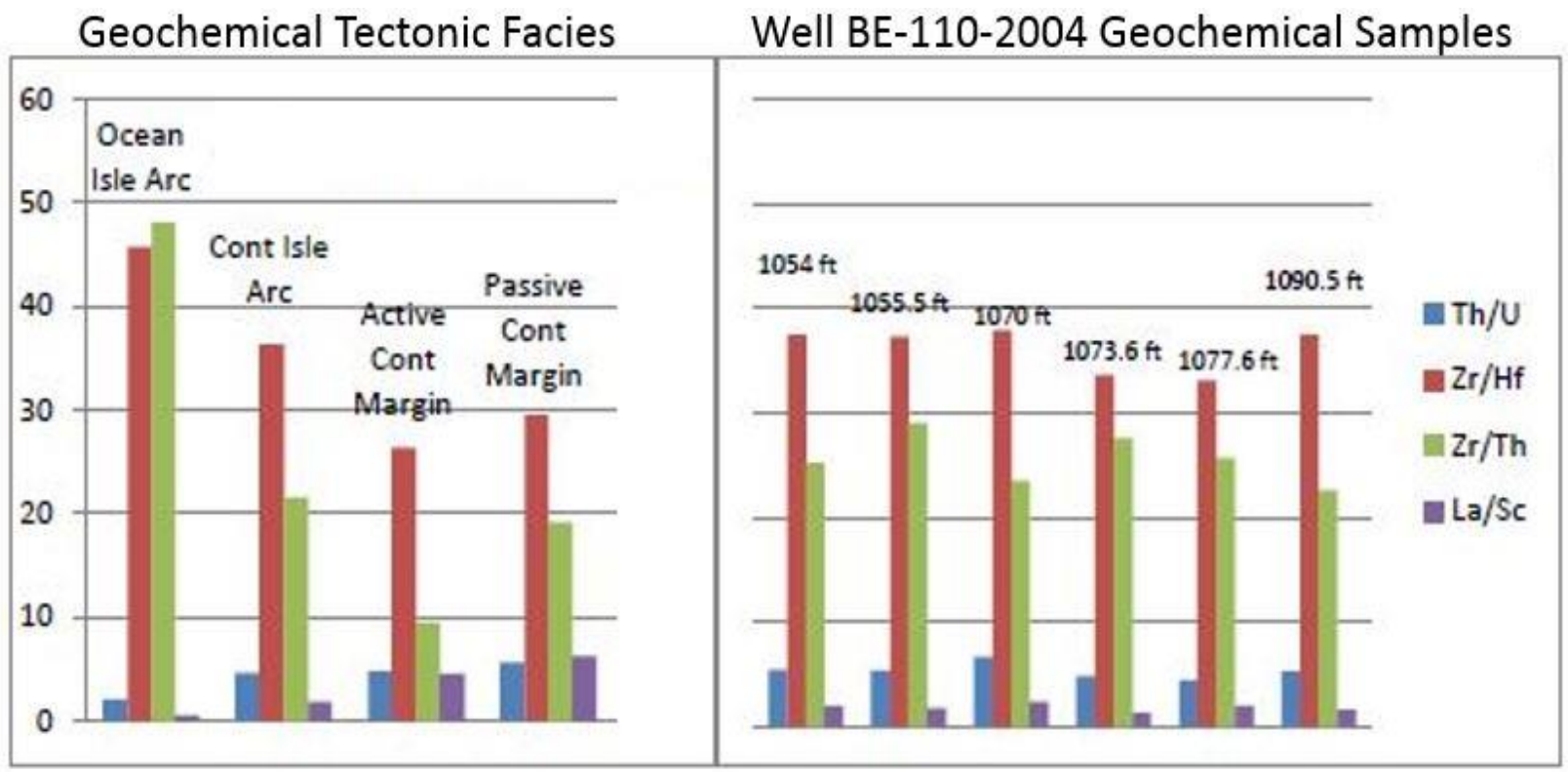

Figure 29: Bar graphs of geochemical tectonic facies based on ratios of rare earth elements (Bhatia and Crook, 1986) and geochemical analysis of whole rock samples (Poythress R., unpublished data) relating tectonic setting.

While the results do not conclusively correspond with a tectonic province, some general trends in ratios are observed. The geochemical analysis shows characteristics of trace element ratios in both continental island arc and active-continental-margins tectonic settings. A diagram and ternary plots of different trace element ratios (Figure 30), further support that the initial tectonic province was a continental island arc. One interpretation of these data is that the sediments in the concealed basin have undergone multiple orogenies and denudation events eliminating any conclusive geochemical signatures of the Triassic strata within the basin.
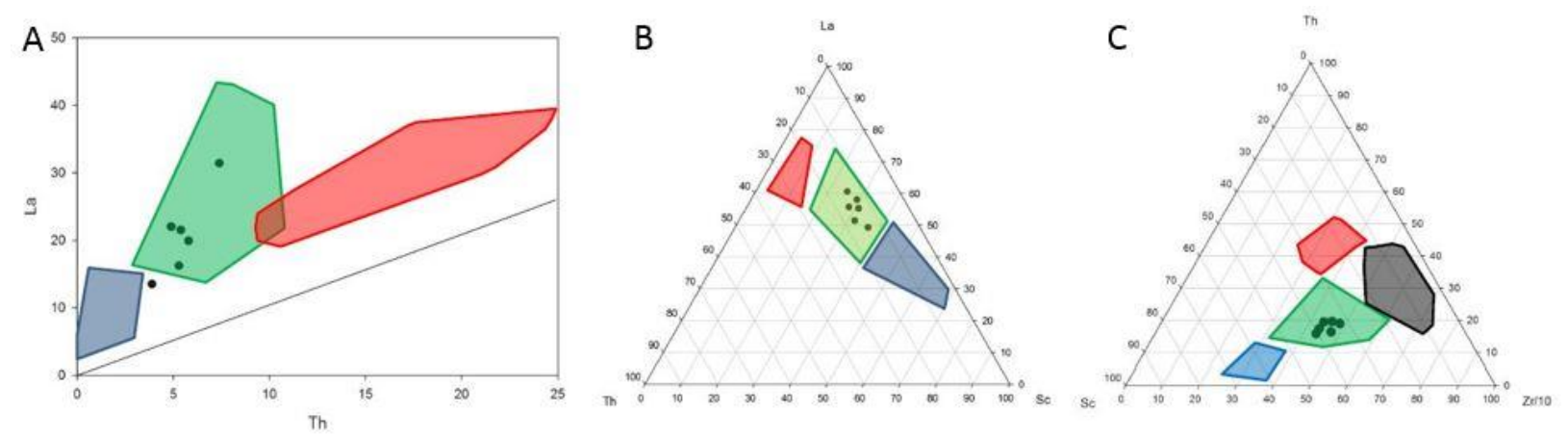

Figure 30: Graphs of trace element ratios and provenance zones from geochemical analysis of whole rock samples from well BE-110-2004. A) Plot of La-Th ratios. The black line represents a 1:1 ratio. B) Ternary plot showing LaTh-Sc values. C) Ternary plot showing Th-Sc-Zr/10 values. Blue is Oceanic Island Arc, Green is Continental Island Arc, and Red/Black represents both Active and Passive Continental margins. (Poythress R., unpublished data) 


\section{Magnetic Susceptibility}

Magnetic susceptibility is a characteristic property of materials and is useful for constraining mineral content in geologic samples. When a material is placed in an external magnetic field, such as the Earth's magnetic field, it will be magnetized proportionally to the strength of the field. Magnetic susceptibility is the constant of proportionality between the induced and external magnetic fields. Based on magnetic susceptibility values, minerals are classified as diamagnetic or paramagnetic. Diamagnetic materials have low negative susceptibilities and can be considered negligible during geophysical surveys. Examples are quartz and feldspars. Paramagnetic minerals have positive susceptibilities, but generally have low values. Examples are pyroxene, amphibole, and olivine.

In some paramagnetic minerals, however, magnetic moments can align forming small areas referred to as magnetic domains. If the magnetic domains within a material are parallel, very high susceptibilities can occur and the material is termed ferromagnetic. These materials do not occur naturally on earth, however, and are of no interest in geophysical exploration. If the domains are parallel and antiparallel so that the net magnetic moment is zero, the material is termed antiferromagnetic. In some minerals referred to as ferrimagnetic (magnetite, titanomagnetite, ilmenite, and pyrrhotite), magnetic domains generally orient themselves as antiferromagnetic materials but have a preferred direction of orientation. When ferrimagnetic minerals are exposed to an external field, internal magnetic domains can flip orientation resulting in a larger induced magnetic field and relatively high magnetic susceptibility. It is these minerals, the most common of which is magnetite, that are used for studies of magnetic susceptibility of rocks in Earth's crust. Variations in magnetic susceptibility of sediments and sedimentary rocks 
may be used for many interpretations including provenance, sedimentary environment, and identifications of facies changes (Verosub and Roberts, 1995).

For the BE-110-2004 core, measurements were taken every six inches when possible with initial measurements beginning at a depth of approximately $880 \mathrm{ft}$., identified as Cretaceous in age, and preceded into Triassic sections of the core, ending at a depth of roughly $1086 \mathrm{ft}$ (Poythress R., unpublished). These depths were chosen based upon lithology descriptions from the USGS, and sample intervals present in core boxes (Figure 31).
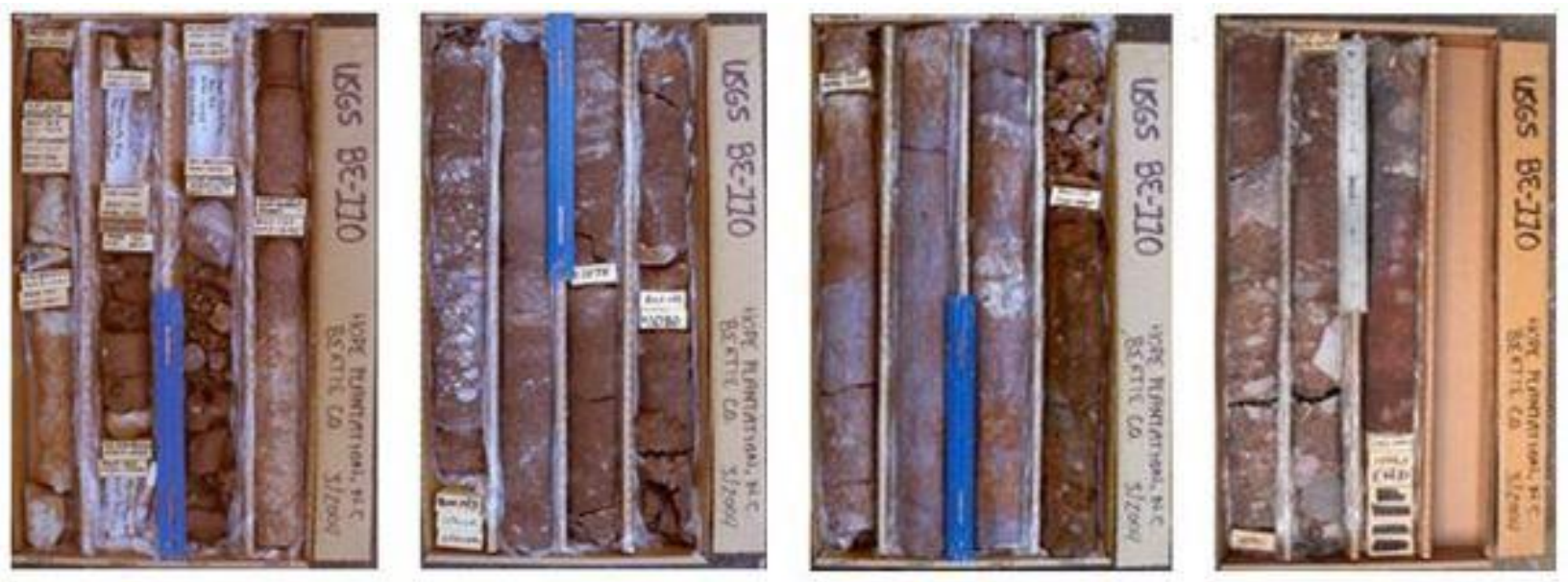

Figure 31: Photographs of cores taken from well BE-110-2004 showing Triassic strata. (Weems et al., 2007)

The values of magnetic susceptibility range from approximately -32 si to 18 si. Beginning with Cretaceous sediments at $880 \mathrm{ft}$, and continuing to a depth of approximately 1,000 ft, values generally trend towards higher magnetic susceptibility. This rate is roughly $.43 \mathrm{cgs} / \mathrm{ft}$ with increasing core depth (Poythress R., unpublished). At depths greater than approximately 1,000 ft, values trend toward lower magnetic susceptibility. To test the significance of these trends, Kmeans clustering was used which involves selecting n number of points or clusters, which serve as cluster seeds. These serve as initial points for calculating clusters means. The calculation is then run repeatedly until the lowest possible mean of distance from the center of the cluster is achieved, resulting in a "tighter" cluster. The USGS identifies a depth of roughly 1,000 $\mathrm{ft}$ as the 
transition between Triassic and younger sediments. As shown by Figure 32, this coincides roughly with the transition between closed and open circle clusters. While there is no definitive boundary between the Cretaceous and Triassic sediments, the sediments classified as Triassic tend to have lower magnetic susceptibility than the overlying Cretaceous sediments. An abundance of quartz observed in thin section analysis could be one explanation for the decreasing susceptibility values. As the abundance of quartz increases, the relative abundance of paramagnetic and ferrimagnetic minerals decreases.

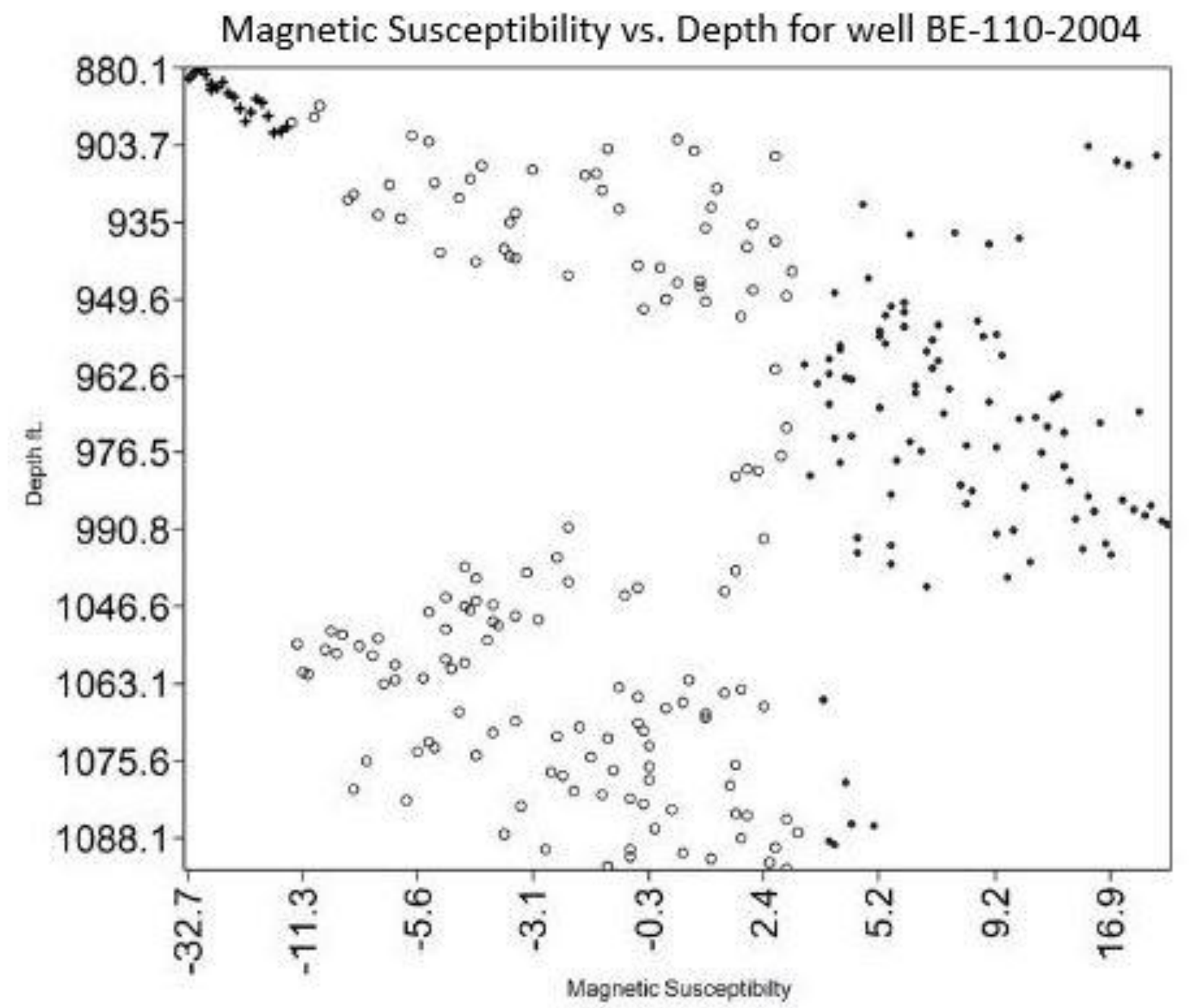

Figure 32: Magnetic susceptibility of core samples from well BE-110-2004 starting at a depth of $880.1 \mathrm{ft}$ to the end of the core at $1096 \mathrm{ft}$. A significant decrease in susceptibility occurs at approximately 1,000 ft where the transition to Triassic strata has been identified. (Poythress R., unpublished data) 


\section{Local Geology}

Previous work has identified the basement lithology for Bertie County, and classified it as part of the Roanoke Rapids Terrane. In a belt east of Greenville, Pitt County NC, metamudstones and metasandstones make up more than 50 percent of the stratigraphic section, and metavolcanic rocks are subordinate (Lawrence and Hoffman, 1993). East of a line passing from central Bertie County through eastern Pitt County, basement rock consists of wide bands of low magnetic susceptibility interpreted as metamorphosed sedimentary rocks and felsic volcanics interspersed with narrow bands of north-south trending mafic rocks with high magnetic susceptibility (Lawrence and Hoffman, 1993).

Two wells in Bertie county, BT-T-1-73 and BT-T-1-82, have encountered crystalline basement rock and therefore provide loose constraints on the size of the basin. Well BT-T-1-73, at a depth of $1,058 \mathrm{ft}$, penetrated a metamudstone with slaty cleavage, of a proposed volcaniclastic origin (Lawrence and Hoffman 1993). Well BT-T-1-82, at a depth of $621 \mathrm{ft}$, penetrated an unfoliated metavolcanic rock interpreted as an intermediate crystal lapilli tuff. In addition to adjacent wells, existing geophysical data examined by Lawrence and Hoffman (1993) showed no evidence of a concealed basin. Newer gravitational data taken from the Pan-American Center for Earth and Environmental Studies (PACES) database are consistent with a minor basin or some other small, low-density feature (Figure 33). 


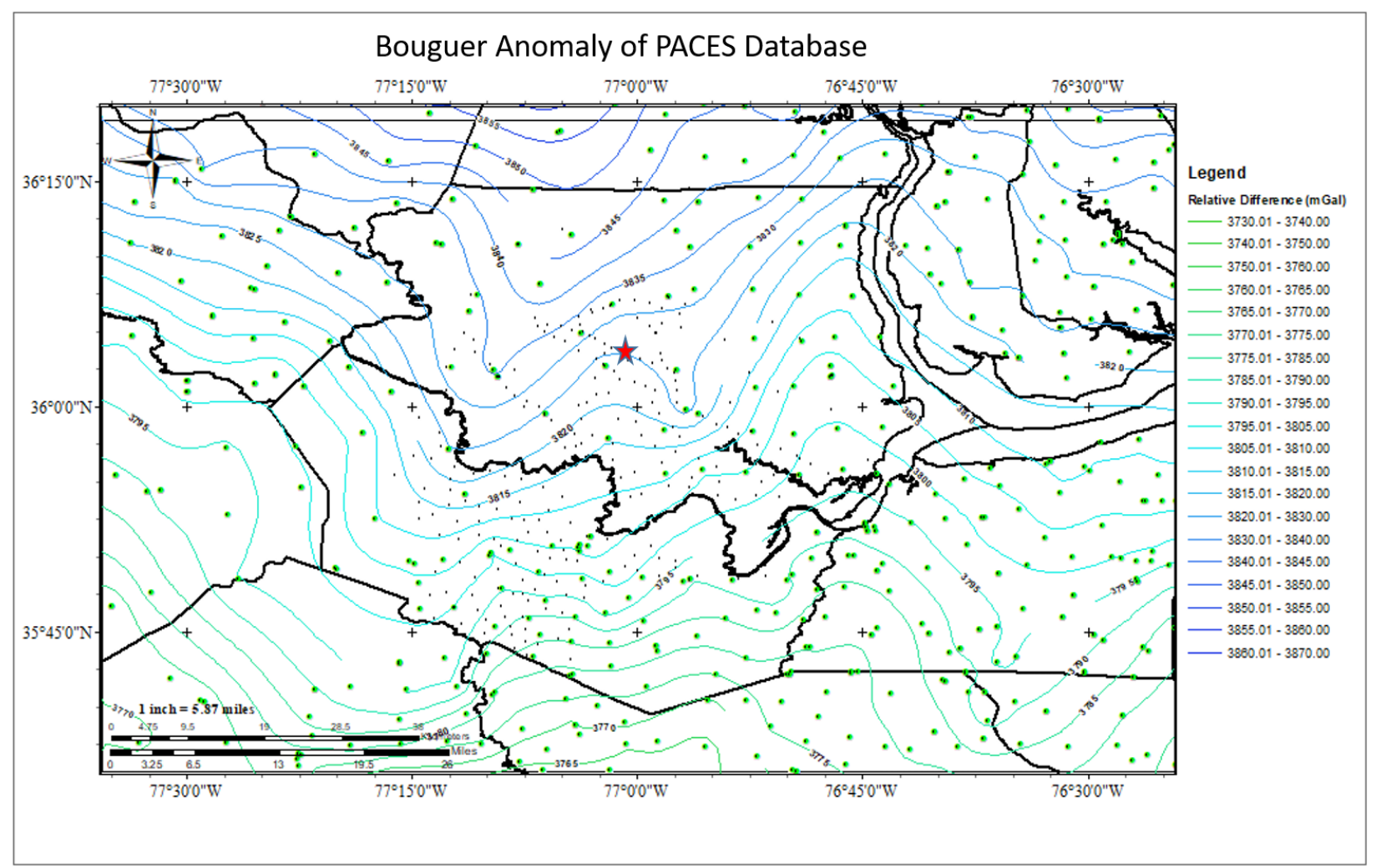

Figure 33: Bouguer anomaly contour map of Bertie County, NC, and surrounding area derived from PACES database. Dots are PACES stations and the star is the location of the Hope Plantation. Small scale bending of the contours loosely suggests the presence of a low-density subsurface structure.

Geophysical surveys can provide constraints on the size and geometry of the buried Triassic rift basin. These constraints, in turn, can be used to develop hypotheses about the conditions that existed during its formation. For this project, a gravity survey was conducted in the region of Bertie County, North Carolina, centered around the Hope Plantation (Figure 34). The data were used to constrain the dimensions, geometry, density, and structural variation of the rift feature. 


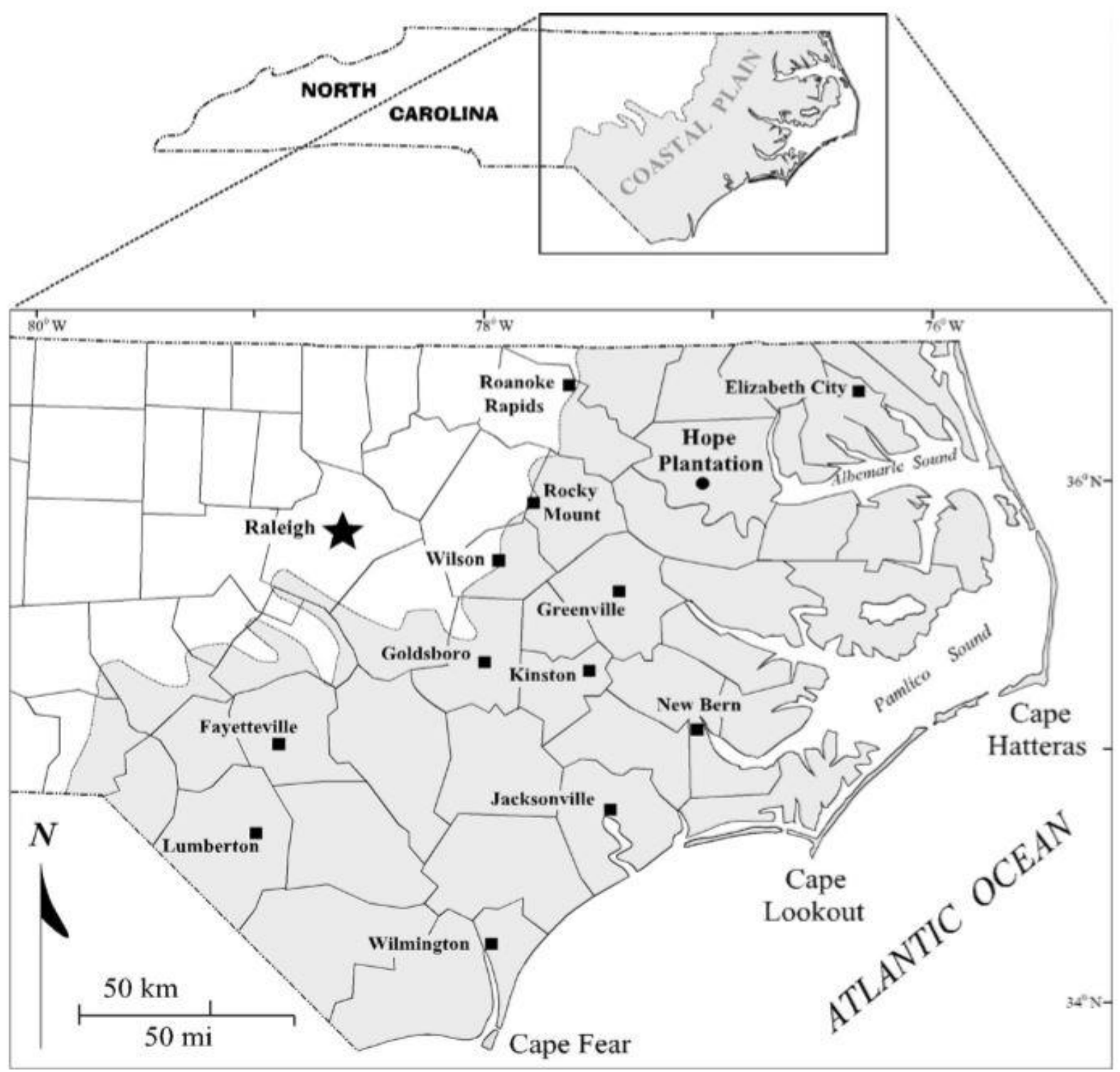

Figure 34: Map of eastern North Carolina showing the Coastal Plain (gray) and the location of the Hope Plantation in Bertie County. (Weems et al., 2007) 


\section{Chapter 7: Gravity Surveys}

Gravity measurements determine the acceleration due to gravity either directly (absolute measurements) or by comparison to other locations (relative measurements). Gravitational

acceleration is measured in Gals, defined as 1 centimeter per second squared $\left(1 \mathrm{~cm} / \mathrm{s}^{2}\right)$. Absolute measurements are generally based on the falling body method which measures free-falling velocities to calculate gravitational acceleration. Accurate determinations of absolute gravity can be made to a precision of $0.01 \mathrm{mGal}$, or 0.00001 percent of average Earth gravity. Instruments designed to achieve that precision can be cumbersome, difficult to transport, and require significant time to set-up and use, making them inconvenient for gravity exploration. Absolute gravity values are critical, however, in providing a framework of known values to tie data from gravity surveys to real-world values and to compare world-wide gravity measurements. A complete and consistent network of 1800 observation sites around the world recorded absolute gravity values utilizing the free-fall approach and were published in 1971, referred to as the International Gravity Standardization Net (IGSN71). Every gravity survey should be tied to one of the IGSN71 sites.

Relative gravity measurements are based on the principles of a pendulum and record the difference in gravitational acceleration between two or more locations. In theory, if a mass is suspended on a spring and the apparatus is moved from one location to another, the spring will lengthen or shorten due to variations in gravity. Accurate determination of differences in gravity values between observing stations depend on the model of relative gravimeter used but can be made to a precision of $0.01 \mathrm{mGal}$. Instruments designed to record relative measurements are easier to design, use, and transport than instruments used to measure gravity directly. This makes them ideal for gravity exploration. 
A gravity survey uses relative measurements to detect variations in the densities of subsurface materials by measuring gravity at multiple positions and analyzing the differences in recorded values. The ultimate goal for gravity exploration is to obtain gravity values for which variations are entirely due to the subsurface density distribution. Factors other than subsurface density changes can cause gravity to vary, however, and must be identified and corrected for if the data are to be useful.

\section{Gravity Corrections}

It is important to identify the reasons gravity varies other than subsurface density changes and to correct for them to successfully use gravity to explore the subsurface. Factors such as position on the Earth, elevation, tide and instrument drift, and terrain can all affect gravity values at a locale. Raw gravity data collected during a survey must undergo several corrections before it can be used in any analysis.

The idealized Earth has spherical symmetry, uniform density distribution, and does not rotate, meaning gravity would be the same everywhere on the surface. Because the planet is oblate and rotates, position on the planet's surface causes a gravitational difference from theoretical values of idealized Earth. This difference is due to changes in the distance between the Earth's surface and center of mass, the associated mass difference, and centrifugal force caused by rotation. The net effect of these factors is that gravity varies from 978.0 Gals at the equator to 983.2 Gals at the poles. The latitude correction is a curvature correction that adjusts theoretical gravity values on the Earth's spheroid to values expected for the Geiod, an imaginary surface passing through the worldwide sea-level surface that closely approximates Earth's ellipsoidal geometry. Current values used for the latitude correction were adopted by the International Association of Geodesy in 1967 which resulted in the geodetic reference system formula of 1967, or GRS67. Latitudinal position must be known to within $125 \mathrm{~m}$ to maintain an 
accuracy of $0.1 \mathrm{mGal}$ during gravity surveys. For local surveys, only the latitude is needed for the correction. Generally, measured values do not match values predicted by GRS67 and the difference between the two is referred to as the gravity anomaly.

The free-air correction adjusts gravitational values because of elevation differences between observation stations and a datum, the Geiod. It is calculated by subtracting the latitude correction (theoretical gravity) from the observed gravity and adding a further correction for the station elevation to give the free-air anomaly. Gravitational values decrease approximately $0.3086 \mathrm{mGal} / \mathrm{m}$ as distance increases from Earth's center. To maintain an accuracy of $0.1 \mathrm{mGal}$ for the free-air correction during gravitational surveys, elevation of the observation point needs to be known to within $33 \mathrm{~cm}$. The free-air anomaly is only corrected for elevation above or below sea level and does not consider the associated mass difference between the observation point and Geiod.

A third correction, the Bouguer correction, removes the effect of the additional mass between the GRS67 datum and the observation point. The value of the correction is $0.04193(\rho z)$, where $\rho$ equals density and $z$ is elevation. This value is subtracted from the free-air anomaly if the observation point is above sea-level and added if it is below to give the Bouguer anomaly. A density must be selected for calculating the Bouguer anomaly, and most often the average density for crustal rocks, $2.67 \mathrm{~g} / \mathrm{cm}^{3}$, is used for data reduction.

Terrain corrections correct the Bouguer anomaly for irregularities in the terrain in the vicinity of the stations. Terrain corrections account for undulations of topography above and below the elevation of the observation point which alter local gravitational values. The most common approach for terrain corrections, proposed by Hammer (1939), considers the gravity effect of a ring or concentric circles surrounding the observation point. Sectors of each ring with 
average thicknesses and mass are used to compute a total terrain correction, the net gravitational effect due to local or regional topography.

During the course of a gravity survey, readings taken from the same position will vary thru time. This variation is caused by both instrument drift, small changes in physical constants of the gravimeter, and tidal effects, which are governed by the position of the moon and sun relative to Earth. These factors can cause variations in gravity outside of the targeted precision, $0.01 \mathrm{mGal}$ for most projects, and must be corrected for. Tidal variations affect gravity measurements by as much as $+/-0.15 \mathrm{mGal}$ at a rate of $0.05 \mathrm{mGal} / \mathrm{hour}$. Tidal effects can be accurately predicted for any location and corrections via computer programs can often be made. Instrument drift cannot be predicted, however, and must be accounted for by repeatedly returning to a reference point to determine the magnitude of drift over time. This technique is known as looping.

Looping is achieved by setting up base stations within the survey area that allow gravity readings to be repeated at the same location every few hours. A base station is established by relating measurements at a given locality to the nearest IGSN71 station or another established base station and calculating the absolute gravity value. The looping sequence begins and ends with measurements at the base station, the difference from which records the amount of drift that has occurred during an elapsed time. If the elapsed time is short enough, linear drift can be assumed and corrections can be applied to readings from stations along the loop with relatively small error.

The complete Bouguer anomaly is the gravitational value after all corrections have been made in the raw data reduction process. If calculated correctly, relative gravitational differences between locations are only due to subsurface density contrasts. Modeling of the complete 
Bouguer anomaly can constrain density, dimensions, and geometry of the subsurface rock bodies. Gravity modeling is limited in its ability to map subsurface structures, however, because non-unique solutions arise from multiple combinations of density, thickness, and depth of rock bodies that match the observed gravity value. Therefore, it is pertinent to include as much geologic data (i.e. cores, maps, densities, geophysical surveys, etc.) as possible to supplement gravitational modeling and limit error. After a functional model has been developed, the process of anomaly separation can filter the gravitational effect of smooth, large-scale, regional trends resulting in a residual anomaly. Residual values are related to small and near-surface features highlighting local density distributions within the model. In a similar process, upward continuation can filter near-surface density features leaving behind only large-scale regional gravitational anomalies. 


\section{Chapter 8: Forward Modeling}

The initial work for the project was forward modelling with Oasis: Montaj to become familiar with Bouguer anomaly data. The purpose of this is to develop knowledge of how the magnitude of the gravity anomaly is affected by changes in size, depth, geometry, and density of subsurface structures. This knowledge is useful for a quick interpretation of basin geometry from data collected in the initial survey to identify the basin's approximate boundaries. The Hope Plantation core identified Triassic strata, but the relative position of that core within the basin was undefined and a wide study region was necessary for complete coverage of the basin.

Initial forward models were designed to test how size and depth affect the magnitude of the gravity anomaly. A uniformly dense, $2.67 \mathrm{gm} / \mathrm{cm}^{3}$, crustal block with a thickness of $100 \mathrm{~km}$ and length ranging from $-30,000 \mathrm{~km}$ to $30,000 \mathrm{~km}$ was used for initial construction of the model. A wedge-shaped basin bounded by a fault dipping at 60 degrees was then inserted at the center of the crustal block. More than 250 gravity stations spaced at $100 \mathrm{~m}$ intervals across the origin were used in the models. Four cross-sections of a basin with depths of $0.5,1,1.5$, and $2 \mathrm{~km}$, exposed at the surface, and with infill of a density of $2.45 \mathrm{gm} / \mathrm{cm}^{3}$ were created (models A1 through A4) from which the maximum value of the gravitational anomaly was recorded. This process was then repeated for burial of the basin at $0.3 \mathrm{~km}$ (models A5 through A8) and $1 \mathrm{~km}$ (models A9 through A12) underneath a uniform layer of sedimentary rock with a density of 2.2 $\mathrm{gm} / \mathrm{cm}^{3}$ (Appendix D). Results show anomaly values increase between 2 and $3 \mathrm{mGal}$ for every $0.5 \mathrm{~km}$ increase in basin depth. The anomaly decreased by approximately $1 / 2 \mathrm{mGal}$ with every kilometer of burial underneath sediments (Table 1). Generally, gravity signatures are symmetric for buried basins and do not reflect the asymmetric wedge-shaped structure of the basin. 
Table 1: Maximum gravitational anomaly of basins with varying sizes and burial depths

\begin{tabular}{c|ccc}
\hline \multirow{2}{*}{$\begin{array}{c}\text { Maximum Thickness of Basin } \\
(\mathrm{km})\end{array}$} & \multicolumn{3}{|c}{ Maximum Gravitational Anomaly (mGal) } \\
\cline { 2 - 4 } & Surface & Depth of Burial of Basin \\
& 2.28 & 1.39 & Burial of 0.3 km \\
\hline 0.5 & 4.66 & 3.63 & Burial of 1.0 km \\
1.0 & 7.36 & 6.22 & 2.31 \\
1.5 & 10.11 & 8.45 & 4.54 \\
2.0 & & & 6.21 \\
\hline
\end{tabular}

Sensitivity of the maximum gravitational anomaly was tested (models B1 through B12, Appendix D), by varying the density of basin infill to $2.3,2.4,2.5,2.6 \mathrm{gm} / \mathrm{cc}$ for a $2 \mathrm{~km}$ thick basin exposed at the surface and buried at depths of $0.3 \mathrm{~km}$ and $1 \mathrm{~km}$. Table 2 shows the maximum gravitational anomaly for the model is sensitive to the density of basin infill, with increases of approximately $3 \mathrm{mGal}$ for every $0.1 \mathrm{gm} / \mathrm{cm}^{3}$ decrease in density. The anomaly goes to zero as the density approaches the crustal density, as would be expected. Models C1 through C5 (Appendix D) tested sensitivity of the gravity anomaly to overlying sediment density variations by ranging densities from 1.9 to $2.4 \mathrm{gm} / \mathrm{cm}^{3}$ by $0.1 \mathrm{gm} / \mathrm{cm}^{3}$ increments, modeled after a $2 \mathrm{~km}$ thick basin buried at a depth of $0.3 \mathrm{~km}$. Table 3 demonstrates that the gravitational anomaly caused by the basin is unobscured by density changes in overlying sediments. Overlying sediment density only contributes to changes in the absolute gravity value.

Table 2: Maximum gravitational anomaly of $2 \mathrm{~km}$ thick basin with varying Triassic strata density and burial depth

\begin{tabular}{c|ccccc}
\hline Maximum Depth of Basin $(\mathrm{km})$ & \multicolumn{5}{|c}{ Maximum Gravitational Anomaly (mGal) } \\
\cline { 2 - 5 } & \multicolumn{4}{|c}{ Density of Triassic Sedimentary infill (gm/cc) } \\
& 2.3 & 2.4 & 2.45 & 2.5 & 2.6 \\
\hline Surface & 16.78 & 12.33 & 10.11 & 7.88 & 3.26 \\
0.3 & 14.48 & 10.41 & 8.45 & 6.49 & 2.56 \\
1.0 & 10.79 & 7.74 & 6.21 & 4.69 & 1.64 \\
\hline
\end{tabular}


Table 3: Maximum gravitational anomaly of $2 \mathrm{~km}$ thick basin with varying densities of overlying sediments

\begin{tabular}{cc}
\hline $\begin{array}{c}\text { Density of Overlying Coastal Plain Sediments } \\
(\mathrm{gm} / \mathrm{cc})\end{array}$ & $\begin{array}{c}\text { Maximum Gravitational Anomaly } \\
(\mathrm{mGal})\end{array}$ \\
\hline 1.9 & 8.75 \\
2.0 & 8.58 \\
2.1 & 8.75 \\
2.2 & 8.92 \\
2.3 & 8.91 \\
2.4 & 8.75 \\
\hline
\end{tabular}

Several more models, D1 through D7, looked at how the gravitational anomaly signature is affected by domino-style faulting, density variations between the footwall and hanging wall, changes in depth at which faults become horizontal, and dipping basement surfaces (Appendix D). In one model, density variations between the footwall and hanging wall of only $0.07 \mathrm{gm} / \mathrm{cm}^{3}$ caused negative sloping anomalies of 30 to $40 \mathrm{mGal}$ over relatively short distances, approximately $25 \mathrm{~km}$ (Figure 35).

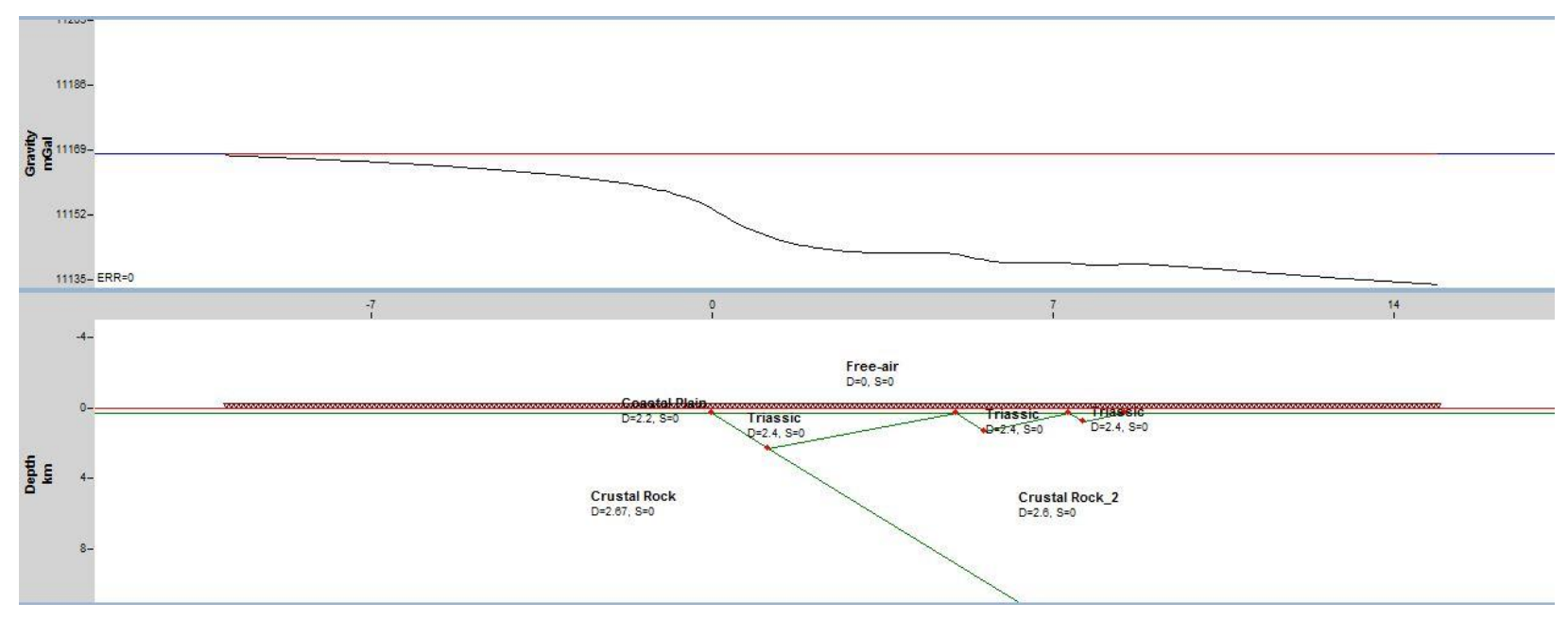

Figure 35: Forward modeling showing gravitational anomaly caused by domino-style faulting and crustal blocks of different densities. Vertical exaggeration $=2 \mathrm{x}$

Forward modeling of basins of different size, burial depth, and stratigraphic densities reveal how the gravitational signature will change due to variances of these parameters. 
Generally, the gravitational signature is symmetrical for wedge-shaped basins buried at some depth. The magnitude of the signature increases with basin thickness and decreases with burial depth. Horizontal overlying sedimentary units do not affect the gravitational signature of the basin despite significant density variation. The density of Triassic basin infill does significantly affect the magnitude of the gravity anomaly, however, with lower densities increasing the gravitational anomaly and higher densities decreasing it. Finally, small variations, in basement rock density between the footwall and hanging wall, as small as $0.07 \mathrm{gm} / \mathrm{cm}$, can cause 30 to 40 $\mathrm{mGal}$ negative gravitational anomalies. If a rift basin forms at a fault system that separates different rock suites, which is often the case, the gravitational signature can be greatly affected and must be accounted for or the modeled basin will be much too large. 


\section{Chapter 9: Fieldwork}

A two-stage gravity survey was conducted in Bertie County, NC, with a Lacoste and Romberg Model G gravimeter \#273 to measure spatial variations in gravitational acceleration. The first stage was a coarse survey with station spacing of approximately 5 miles used to constrain the outer boundaries and termination points of the rift basin. For the second stage, a detailed survey with more than 200 closely spaced stations, separated by approximately 1 mile, throughout Bertie and Martin counties, NC, was conducted based on the analysis of the coarse survey data. Data gathered from the detailed survey helps to constrain the surface between overlying sediment and the significantly denser bedrock underneath to reveal the rift basin. Data reduction and inverse modeling of the accumulated data was done through the software Oasis: Montaj from which a contour map of the Bouguer anomaly and cross-sectional models were created. The models of the subsurface basement rock and basin characteristics were then analyzed, interpreted, and compared to other rift basins along the North Atlantic rift margin.

Prior to data collection, aerial maps of the study area were created in ArcGIS showing county lines and roads from which tentative station locations were chosen based on accessibility and spacing. Included with these maps were previously collected gravity data used to help in locating the basin's boundaries and to approximate its size (PACES) and LiDAR elevation data used in later analysis. The map files were uploaded into a program on an iPad connected to a handheld GPS that was used in the field to allow for real-time position information and to record the position of chosen observation sites.

Data collection was done in late July and early August, 2018, over the course of three weeks. The first step of this process was to set-up a base station within the study site and tie it to an absolute station, a known location and gravitational value. Gravitational readings vary 
depending on individual pieces of equipment and must be correlated with an absolute base station to have significance outside of a single locality. This correlation also allows for drift corrections of the data as part of the data reduction process. The absolute base station used for this survey is located at East Carolina University, Flanagan Hall in Greenville, NC. Designated GREENVILLE AA by the NOAA-NGS, it is marked by a disk cemented into the linoleumcovered concrete floor in the west part of the Flanagan building in room 111. The marker is located at latitude $35^{\circ} 36^{\prime} 23.08^{\prime \prime} \mathrm{N}$, longitude $77^{\circ} 22^{\prime} 00.29^{\prime}$ ' W, at an elevation of 11.68 meters with an absolute gravity value of $979,777.828+/-0.004$ mGals. The local base station at the study site was established in the parking lot behind the post office in Windsor, North Carolina, on a small concrete pad just behind the mail dropbox at latitude $35^{\circ} 59^{\prime} 38.72^{\prime \prime} \mathrm{N}$ and longitude $76^{\circ} 57^{\prime} 03.49^{\prime}$ W. A total of three loops between the two locations allowed for a precise calculation of 979823.1 mGal for the absolute gravity value of the base station (Table 4).

Table 4: Absolute gravity values for absolute and local base stations

\begin{tabular}{cccccc}
\hline Station & Station Name & Latitude & Longitude & Elevation (m) & Gravity (mGal) \\
\hline 99999 & FLANBASE & 35.606411 & -77.366747 & 11.68 & 979777.8 \\
99998 & WINBASE & 35.994089 & -76.950969 & 3.63 & 979823.1 \\
\hline
\end{tabular}

A coarse survey was conducted throughout central and southeast Bertie County composed of approximately 50 stations spaced roughly 5 miles apart. At each gravity station the time, gravimeter reading, latitude, longitude, and elevation were recorded. Quick analysis of coarse survey data exposed the bounding margins of the basin and the northern termination point. The southern end of the basin, however, extended into Martin County, located directly south of Bertie County, and outside the extent of the initial survey area. A second survey was extended over an area of roughly 1000 square kilometers in central and southwest Bertie County and western Martin County, North Carolina, consisting of 247 stations separated by roughly 1 
mile, giving much improved resolution of basement rock (Figure 36). Before day's travel to the field area, an initial reading was taken at the absolute base station located at East Carolina University. Once on location, the second measurement was taken at the Windsor base station, followed by a loop of stations ending back at the base station. Because these loops overlapped with one another, several stations were repeatedly measured, known as tie lines, to assist in error analysis including multiple measurements at the Hope Plantation, where the well was drilled.

Sixteen of the 247 stations, $6.5 \%$, are repeated measurements internal to the survey which recorded a mean error of $0.044 \mathrm{mGal}$ and RMS error of $0.056 \mathrm{mGal}$. Several observation stations were also tied to previous measurements recorded in the PACES database to further constrain error analysis. Special attention was given along transects to be used in the analysis and along the western margin in order to obtain the best estimates of fault dip.

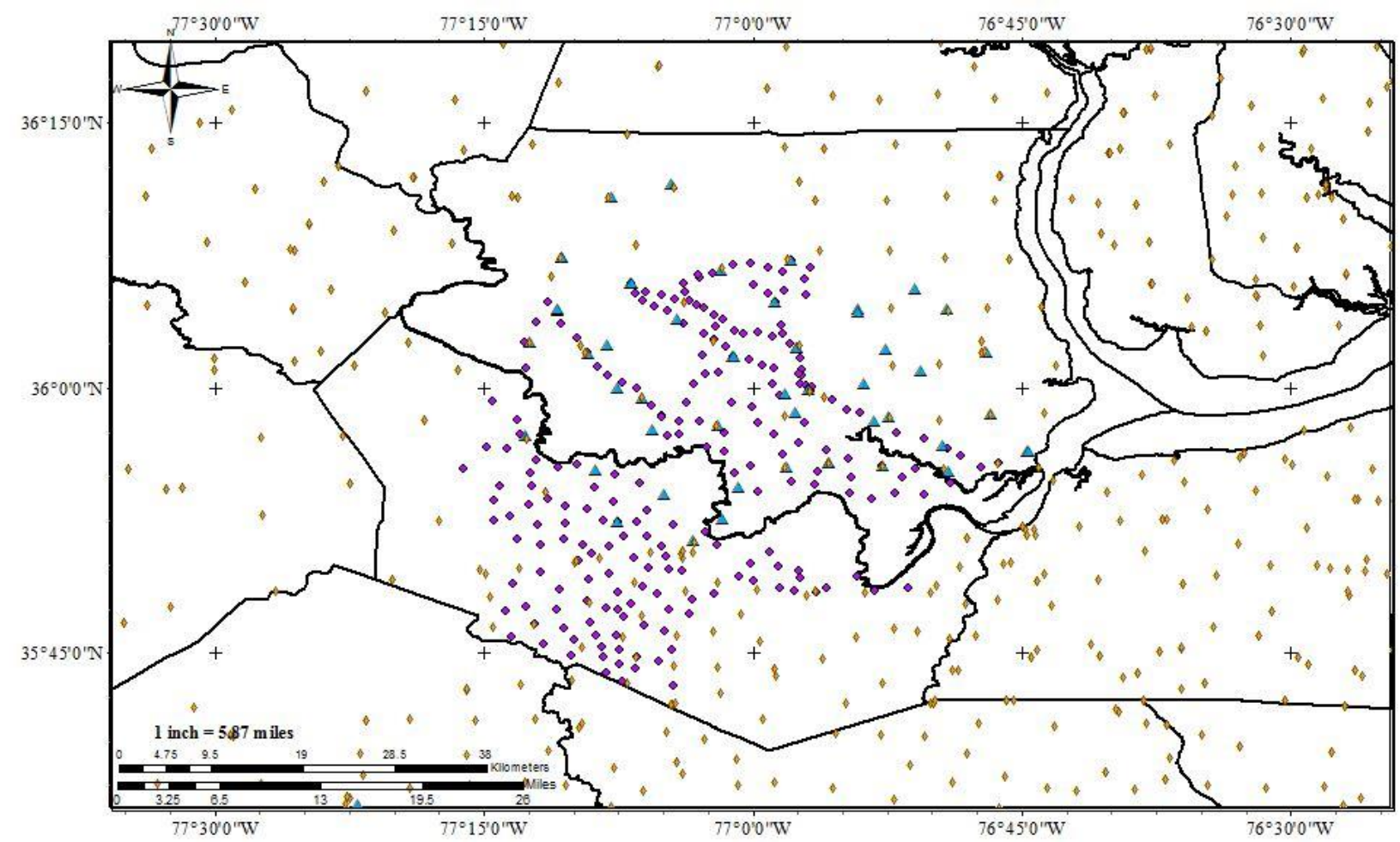

Figure 36: Station locations from gravity survey and PACES database. Yellow diamonds are PACES locations, blue triangles are coarse survey stations, and purple diamonds are detailed survey stations 


\section{Chapter 10: Analysis/Inverse Modeling:}

Data processing, modeling, and integration with preexisting data was accomplished using Oasis:Montaj software. This program applied a series of corrections used in reduction of the raw gravitational data. These corrections include: Instrument scale factor, latitude correction, free air correction, Bouguer correction, terrain correction, tide correction, and instrument drift.

Governing equations for all corrections can be found in Appendix E. Gravity values were then derived from these corrections for each of the observation stations in the survey.

The instrument scale factor relates counter readings from the gravimeter to a relative milligal value based on instrument calibration. The scale factor is included in the instrument's manual (Appendix E) and was uploaded into Oasis: Montaj to convert instrument readings into gravitational values. The latitude correction was achieved using the GRS67 formula. Elevation data from LiDAR mapping in ArcGIS and an assumed background density of $2.67 \mathrm{gm} / \mathrm{cc}$ allowed for the free air and Bouguer corrections to be made.

Terrain corrections use both a regional coarse Digital Elevation Model (DEM) over a large extent and a more detailed local DEM. In this case, $90 \mathrm{~m}$ and $30 \mathrm{~m}$ DEMs were used (sourced from NASA's Shuttle Radar Topography Mission) for the regional and local terrain corrections, respectively. Since the Coastal Plain is relatively flat, these corrections were small with an average correction between 0.4 and $0.5 \mathrm{mGal}$. Tide corrections were wholly calculated by programming within Oasis: Montaj and instrument drift corrections were calculated from looping sequences done in the field. Table 5 shows the data collected from the field and the corrections applied within Oasis:Montaj.

The first three columns in Table 5 are the station id and coordinates. The reading column is the measurement value from the gravimeter. The values in the elevation column were derived 
from a Lidar elevation map and used for data reduction. The values for the tide, terrain, free air,

bouguer, and complete bouguer corrections are shown in columns 6 through 10, respectively.

The gravity average column is the corrected gravity value for each station. The repeated

difference column shows the difference between measurements for repeat stations (tie lines).

Table 5: Gravity survey data and corrections

\begin{tabular}{|c|c|c|c|c|c|c|c|c|c|c|c|}
\hline Station & Lat. & Long. & Reading & $\begin{array}{l}\text { Elev } \\
(\mathrm{m})\end{array}$ & $\begin{array}{c}\text { Tide } \\
\text { Corr. } \\
(\mathrm{mGal})\end{array}$ & $\begin{array}{l}\text { Terrain } \\
(\mathrm{mGal})\end{array}$ & $\begin{array}{c}\text { FreeAir } \\
(\mathrm{mGal})\end{array}$ & $\begin{array}{c}\text { Bouguer } \\
(\mathrm{mGal})\end{array}$ & $\begin{array}{c}\text { C_Bouguer } \\
(\mathrm{mGal})\end{array}$ & $\begin{array}{l}\text { Gravity } \\
\text { Avg. } \\
\text { (mGal) }\end{array}$ & $\begin{array}{l}\text { RepDiff } \\
(\mathrm{mGal})\end{array}$ \\
\hline 10001 & 35.972750 & -76.873150 & 3377.51 & 7.3 & -0.004 & 0.42 & -5.74 & -6.57 & -6.15 & 979808.0 & \\
\hline 10002 & 35.945360 & -76.822500 & 3369.44 & 9.6 & -0.007 & 0.43 & -11.20 & -12.29 & -11.85 & 979799.5 & \\
\hline 10003 & 35.939690 & -76.744070 & 3368.72 & -0.2 & -0.010 & 0.31 & -14.37 & -14.35 & -14.04 & 979798.8 & 0.11 \\
\hline 10003 & 35.939690 & -76.744070 & 3369.03 & -0.2 & 0.002 & 0.31 & & & & & 0.11 \\
\hline 10004 & 35.920630 & -76.817100 & 3367.17 & 8.7 & -0.012 & 0.43 & -11.74 & -12.72 & -12.30 & 979797.1 & \\
\hline 10005 & 35.926870 & -76.879310 & 3375.15 & 4.9 & -0.018 & 0.40 & -5.62 & -6.17 & -5.77 & 979804.9 & 0.07 \\
\hline 10005 & 35.926870 & -76.879310 & 3374.5 & 4.9 & -0.015 & 0.40 & & & & & 0.07 \\
\hline 10006 & 35.929750 & -76.928420 & 3374.95 & 6.0 & -0.015 & 0.41 & -5.06 & -5.73 & -5.32 & 979805.4 & 0.07 \\
\hline 10006 & 35.929750 & -76.928420 & 3375.28 & 6.0 & -0.017 & 0.41 & & & & & 0.07 \\
\hline 10007 & 36.029140 & -77.018310 & 3389.09 & 18.7 & -0.020 & 0.45 & 5.04 & 2.92 & 3.38 & 979820.1 & 0.00 \\
\hline 10007 & 36.029140 & -77.018310 & 3389 & 18.7 & 0.036 & 0.45 & & & & & 0.09 \\
\hline 10007 & 36.029140 & -77.018310 & 3389.01 & 18.7 & 0.126 & 0.45 & & & & & 0.09 \\
\hline 10008 & 36.001680 & -77.064440 & 3398.49 & 19.8 & 0.032 & 0.45 & 17.86 & 15.62 & 16.07 & 979830.2 & \\
\hline 10009 & 36.098330 & -77.112780 & 3408.23 & 17.2 & 0.028 & 0.44 & 18.99 & 17.04 & 17.49 & 979840.5 & 0.04 \\
\hline 10009 & 36.098330 & -77.112780 & 3408.35 & 17.2 & -0.022 & 0.44 & & & & & 0.01 \\
\hline 10009 & 36.098330 & -77.112780 & 3408.31 & 17.2 & 0.136 & 0.44 & & & & & 0.05 \\
\hline 10010 & 36.124270 & -77.183460 & 3402.35 & 23.0 & 0.022 & 0.46 & 12.40 & 9.79 & 10.25 & 979834.3 & 0.03 \\
\hline 10010 & 36.124270 & -77.183460 & 3402.54 & 23.0 & -0.023 & 0.46 & & & & & 0.03 \\
\hline 10011 & 36.180260 & -77.131100 & 3410.94 & 20.6 & 0.018 & 0.45 & 15.90 & 13.56 & 14.01 & 979843.4 & \\
\hline 10012 & 36.195720 & -77.083250 & 3414.57 & 20.6 & 0.012 & 0.45 & 18.39 & 16.05 & 16.50 & 979847.2 & \\
\hline 10013 & 36.111450 & -77.029670 & 3399.87 & 19.7 & 0.006 & 0.45 & 9.80 & 7.58 & 8.03 & 979831.7 & \\
\hline 10014 & 36.081800 & -76.978820 & 3397.41 & 10.9 & 0.052 & 0.43 & 6.93 & 5.70 & 6.13 & 979828.9 & 0.01 \\
\hline 10014 & 36.081800 & -76.978820 & 3397.3 & 10.9 & 0.002 & 0.43 & & & & & 0.01 \\
\hline 10015 & 36.120770 & -76.964150 & 3399.46 & 14.4 & -0.002 & 0.44 & 6.92 & 5.29 & 5.73 & 979831.2 & 0.02 \\
\hline 10015 & 36.120770 & -76.964150 & 3399.56 & 14.4 & 0.003 & 0.44 & & & & & 0.02 \\
\hline 10016 & 36.073800 & -76.902430 & 3391.26 & 12.4 & 0.066 & 0.44 & 1.67 & 0.27 & 0.71 & 979822.5 & 0.00 \\
\hline 10016 & 36.073800 & -76.902430 & 3391.24 & 12.4 & -0.007 & 0.44 & & & & & 0.00 \\
\hline 10017 & 36.037260 & -76.959080 & 3394.11 & 8.5 & 0.072 & 0.42 & 6.60 & 5.63 & 6.06 & 979825.5 & 0.05 \\
\hline 10017 & 36.037260 & -76.959080 & 3394.02 & 8.5 & -0.011 & 0.42 & & & & & 0.05 \\
\hline 10018 & 35.964860 & -77.032060 & 3384.48 & 8.2 & 0.135 & 0.43 & 2.58 & 1.65 & 2.08 & 979815.4 & 0.03 \\
\hline 10018 & 35.964860 & -77.032060 & 3384.5 & 8.2 & -0.023 & 0.43 & & & & & 0.03 \\
\hline 10019 & 35.990780 & -77.102140 & 3393.29 & 12.3 & -0.024 & 0.43 & 10.87 & 9.48 & 9.91 & 979824.6 & \\
\hline 10020 & 36.040160 & -77.135170 & 3403.42 & 12.8 & -0.024 & 0.43 & 17.46 & 16.02 & 16.45 & 979835.3 & \\
\hline 10021 & 36.073330 & -77.180800 & 3401.78 & 14.2 & -0.024 & 0.45 & 13.35 & 11.74 & 12.19 & 979833.6 & 0.04 \\
\hline 10021 & 36.073330 & -77.180800 & 3401.76 & 14.2 & 0.122 & 0.45 & & & & & 0.04 \\
\hline 10027 & 36.093420 & -76.849400 & 3384.72 & 12.2 & 0.059 & 0.44 & -6.99 & -8.38 & -7.93 & 979815.6 & \\
\hline 10028 & 36.074430 & -76.818990 & 3378.25 & 14.0 & 0.051 & 0.45 & -11.66 & -13.25 & -12.80 & $\begin{array}{l}979808.8 \\
\end{array}$ & \\
\hline 10029 & 36.036950 & -76.875660 & 3385.73 & 10.3 & 0.043 & 0.43 & -1.69 & -2.85 & -2.42 & 979816.7 & \\
\hline 10030 & 36.004100 & -76.896200 & 3384.69 & 10.6 & 0.037 & 0.44 & 0.13 & -1.07 & -0.64 & 979815.5 & \\
\hline 10031 & 36.015580 & -76.843130 & 3375.81 & 12.0 & 0.029 & 0.44 & -9.82 & -11.18 & -10.74 & 979806.1 & \\
\hline 10032 & 36.034160 & -76.783090 & 3372.94 & 11.8 & 0.022 & 0.44 & -14.52 & -15.86 & -15.41 & 979803.1 & \\
\hline 10033 & 35.996440 & -76.784840 & 3369.61 & 9.6 & 0.011 & 0.44 & -15.51 & -16.59 & -16.15 & 979799.6 & \\
\hline 10035 & 35.969120 & -76.887410 & 3379.57 & 8.8 & -0.010 & 0.43 & -2.89 & -3.89 & -3.46 & 979810.1 & \\
\hline 10037 & 35.958610 & -77.061940 & 3385.73 & 5.6 & 0.134 & 0.41 & 3.69 & 3.05 & 3.46 & 979816.7 & \\
\hline 10038 & 35.999640 & -77.125150 & 3400.18 & 10.7 & 0.132 & 0.43 & 16.98 & 15.77 & 16.20 & 979832.0 & \\
\hline 10039 & 36.032930 & -77.152740 & 3402.93 & 13.0 & 0.128 & 0.45 & 17.77 & 16.29 & 16.73 & 979834.9 & 0.01 \\
\hline 10039 & 36.032930 & -77.152740 & 3403.13 & 13.0 & 0.130 & 0.45 & & & & & 0.01 \\
\hline
\end{tabular}




\begin{tabular}{|c|c|c|c|c|c|c|c|c|c|c|c|}
\hline 10041 & 36.043190 & -77.207130 & 3400.51 & 8.1 & 0.115 & 0.43 & 12.76 & 11.84 & 12.27 & 979832.3 & \\
\hline 10042 & 35.958440 & -77.198620 & 3394.03 & 22.8 & 0.104 & 0.46 & 17.73 & 15.14 & 15.60 & 979825.4 & \\
\hline 10043 & 35.922920 & -77.146130 & 3386.28 & 8.1 & 0.091 & 0.43 & 8.02 & 7.10 & 7.53 & 979817.2 & \\
\hline 10044 & 35.873920 & -77.124960 & 3374.52 & 13.6 & 0.101 & 0.44 & 1.20 & -0.34 & 0.10 & 979804.5 & 0.02 \\
\hline 10044 & 35.873920 & -77.124960 & 3374.27 & 13.6 & 0.076 & 0.44 & & & & & 0.02 \\
\hline 10045 & 35.899360 & -77.082100 & 3377.67 & 3.4 & 0.064 & 0.38 & -0.55 & -0.93 & -0.55 & \begin{tabular}{|l|l|}
979808.1 \\
\end{tabular} & \\
\hline 10046 & 35.855860 & -77.055280 & 3375.61 & 21.0 & 0.048 & 0.46 & 6.43 & 4.05 & 4.50 & 979805.9 & \\
\hline 10047 & 35.876170 & -77.032070 & 3377.08 & 1.8 & 0.012 & 0.36 & 0.28 & 0.07 & 0.43 & 979807.4 & \\
\hline 10048 & 35.899100 & -77.006560 & 3379.61 & 6.2 & 0.002 & 0.41 & 2.31 & 1.61 & 2.03 & 979810.1 & \\
\hline 10049 & 35.925170 & -76.968800 & 3380.64 & 5.7 & -0.007 & 0.40 & 1.02 & 0.37 & 0.77 & 979811.2 & \\
\hline 10051 & 35.977120 & -76.960300 & 3387.44 & 10.3 & -0.029 & 0.43 & 5.11 & 3.95 & 4.38 & 979818.3 & \\
\hline 11001 & 36.017180 & -76.955100 & 3393.18 & 3.2 & 0.129 & 0.38 & 5.74 & 5.38 & 5.75 & 979824.6 & \\
\hline 11002 & 36.028000 & -76.956330 & 3394.26 & 4.5 & 0.129 & 0.39 & 6.37 & 5.86 & 6.25 & 979825.7 & \\
\hline 11003 & 36.041540 & -76.965680 & 3394.77 & 9.5 & 0.128 & 0.43 & 7.29 & 6.21 & 6.63 & 979826.2 & \\
\hline 11004 & 36.051250 & -76.972780 & 3396.12 & 8.1 & 0.127 & 0.42 & 7.44 & 6.52 & 6.94 & 979827.7 & \\
\hline 11005 & 36.048460 & -76.982160 & 3396.01 & 5.4 & 0.126 & 0.40 & 6.72 & 6.11 & 6.51 & 979827.6 & \\
\hline 11006 & 36.052830 & -76.995820 & 3393.06 & 7.4 & 0.124 & 0.42 & 3.84 & 3.00 & 3.42 & 979824.4 & \\
\hline 11007 & 36.051330 & -77.009160 & 3391.68 & 17.6 & 0.121 & 0.45 & 5.65 & 3.66 & 4.11 & 979823.0 & \\
\hline 11008 & 36.053500 & -77.016630 & 3392.92 & 18.2 & 0.116 & 0.45 & 6.95 & 4.89 & 5.34 & 979824.3 & \\
\hline 11009 & 36.064410 & -77.027460 & 3394.36 & 16.1 & 0.113 & 0.45 & 6.77 & 4.95 & 5.39 & 979825.7 & 0.11 \\
\hline 11009 & 36.064410 & -77.027460 & 3394.26 & 16.1 & 0.127 & 0.45 & & & & & 0.11 \\
\hline 11010 & 36.075900 & -77.045600 & 3396.31 & 18.1 & 0.109 & 0.45 & 8.59 & 6.53 & 6.98 & 979827.8 & \\
\hline 11011 & 36.078390 & -77.052130 & 3397.99 & 16.6 & 0.104 & 0.45 & 9.66 & 7.78 & 8.23 & 979829.6 & \\
\hline 11012 & 36.090560 & -77.063530 & 3402.22 & 17.7 & 0.099 & 0.45 & 13.42 & 11.42 & 11.87 & 979834.1 & \\
\hline 11013 & 36.099370 & -77.064660 & 3405.51 & 12.6 & 0.095 & 0.44 & 14.57 & 13.14 & 13.58 & 979837.6 & \\
\hline 11014 & 36.104610 & -77.049940 & 3404.51 & 10.9 & 0.089 & 0.44 & 12.52 & 11.29 & 11.73 & 979836.5 & \\
\hline 11015 & 36.107070 & -77.050720 & 3403.22 & 14.6 & 0.085 & 0.45 & 12.11 & 10.45 & 10.89 & 979835.1 & \\
\hline 11016 & 36.108430 & -77.036720 & 3401.32 & 14.4 & 0.077 & 0.45 & 9.89 & 8.26 & 8.70 & 979833.1 & \\
\hline 11018 & 36.097220 & -76.999540 & 3396.25 & 16.9 & 0.065 & 0.44 & 6.26 & 4.34 & 4.79 & 979827.7 & \\
\hline 11019 & 36.089210 & -76.985700 & 3397.38 & 10.1 & 0.060 & 0.43 & 6.02 & 4.88 & 5.31 & 979828.9 & \\
\hline 11021 & 36.091660 & -76.971540 & 3398.34 & 11.4 & 0.044 & 0.43 & 7.21 & 5.93 & 6.36 & 979829.9 & \\
\hline 11022 & 36.109170 & -76.971810 & 3399.35 & 12.2 & 0.035 & 0.44 & 7.02 & 5.64 & 6.08 & 979831.0 & \\
\hline 11023 & 36.113910 & -76.986320 & 3398.32 & 17.8 & 0.028 & 0.45 & 7.25 & 5.23 & 5.68 & 979829.9 & \\
\hline 11024 & 36.118060 & -77.002760 & 3399.58 & 16.1 & 0.020 & 0.45 & 7.70 & 5.87 & 6.32 & 979831.2 & \\
\hline 11025 & 36.117010 & -77.018550 & 3400.27 & 18.0 & 0.013 & 0.45 & 9.08 & 7.04 & 7.49 & 979831.9 & \\
\hline 11027 & 36.113420 & -76.947010 & 3398.69 & 18.9 & -0.003 & 0.45 & 7.99 & 5.84 & 6.29 & 979830.2 & \\
\hline 11028 & 36.102690 & -76.952450 & 3398.39 & 17.8 & -0.008 & 0.45 & 8.25 & 6.23 & 6.68 & 979829.9 & \\
\hline 11029 & 36.087810 & -76.950130 & 3398.91 & 10.5 & -0.015 & 0.43 & 7.82 & 6.63 & 7.06 & 979830.5 & \\
\hline 11030 & 36.059150 & -76.973270 & 3396.86 & 8.6 & -0.024 & 0.42 & 7.51 & 6.54 & 6.96 & 979828.3 & \\
\hline 11031 & 36.004190 & -76.955480 & 3389.94 & 10.0 & 0.110 & 0.43 & 5.39 & 4.25 & 4.68 & 979821.0 & \\
\hline 11032 & 36.018330 & -76.979890 & 3388.28 & 17.4 & 0.115 & 0.44 & 4.69 & 2.72 & 3.16 & 979819.2 & \\
\hline 11033 & 36.021930 & -76.990950 & 3388.9 & 15.2 & 0.119 & 0.44 & 4.36 & 2.64 & 3.08 & 979819.9 & \\
\hline 11034 & 36.027020 & -77.002910 & 3390.22 & 14.4 & 0.122 & 0.44 & 5.09 & 3.45 & 3.90 & 979821.3 & \\
\hline 11036 & 36.039120 & -77.025420 & 3390.81 & 15.3 & 0.129 & 0.45 & 4.94 & 3.21 & 3.66 & 979821.9 & \\
\hline 11037 & 36.051910 & -77.045380 & 3393.16 & 15.5 & 0.131 & 0.45 & 6.40 & 4.64 & 5.09 & 979824.4 & \\
\hline 11038 & 36.060900 & -77.064920 & 3396.88 & 18.6 & 0.133 & 0.45 & 10.50 & 8.40 & 8.85 & 979828.3 & \\
\hline 11039 & 36.072500 & -77.079440 & 3402.11 & 18.0 & 0.135 & 0.44 & 14.87 & 12.83 & 13.27 & 979833.9 & \\
\hline 11040 & 36.076880 & -77.091900 & 3405 & 18.9 & 0.136 & 0.45 & 17.81 & 15.67 & 16.12 & 979836.9 & \\
\hline 11041 & 36.083160 & -77.102630 & 3407.01 & 17.1 & 0.137 & 0.44 & 18.86 & 16.92 & 17.36 & 979839.1 & \\
\hline 11042 & 36.089410 & -77.109830 & 3407.92 & 15.6 & 0.137 & 0.44 & 18.81 & 17.04 & 17.48 & 979840.0 & \\
\hline 11044 & 36.090410 & -77.099360 & 3407.88 & 16.7 & 0.135 & 0.44 & 19.02 & 17.13 & 17.57 & 979840.0 & \\
\hline 11045 & 36.088210 & -77.084720 & 3406.03 & 18.9 & 0.134 & 0.45 & 17.93 & 15.79 & 16.23 & 979838.0 & \\
\hline 11046 & 36.083980 & -77.072220 & 3402.46 & 19.5 & 0.132 & 0.46 & 14.70 & 12.49 & 12.95 & 979834.2 & \\
\hline 11047 & 36.082390 & -77.059150 & 3399.68 & 18.5 & 0.130 & 0.45 & 11.59 & 9.49 & 9.95 & 979831.3 & \\
\hline 11049 & 36.058620 & -77.035070 & 3392.78 & 18.0 & 0.124 & 0.45 & 6.19 & 4.14 & 4.59 & 979824.0 & \\
\hline 11050 & 36.045880 & -77.036610 & 3391.7 & 16.4 & 0.119 & 0.45 & 5.64 & 3.78 & 4.23 & 979822.9 & \\
\hline 11051 & 36.030830 & -77.046440 & 3391.3 & 11.5 & 0.116 & 0.44 & 5.01 & 3.70 & 4.14 & 979822.4 & \\
\hline 11052 & 36.013690 & -77.044430 & 3389.1 & 12.1 & 0.111 & 0.44 & 4.32 & 2.95 & 3.39 & 979820.1 & \\
\hline 11053 & 36.014960 & -77.031590 & 3389.31 & 11.1 & 0.106 & 0.44 & 4.13 & 2.87 & 3.30 & 979820.3 & \\
\hline 11054 & 36.003790 & -77.055240 & 3388.4 & 11.4 & 0.081 & 0.44 & 4.17 & 2.89 & 3.32 & 979819.3 & \\
\hline 11055 & 35.985700 & -77.061540 & 3389.98 & 12.4 & 0.074 & 0.44 & 7.71 & 6.31 & 6.75 & 979821.0 & \\
\hline 11056 & 35.969140 & -77.068950 & 3383.75 & 12.1 & 0.141 & 0.44 & 2.52 & 1.15 & 1.59 & 979814.5 & 0.01 \\
\hline 11056 & 35.969140 & -77.068950 & 3383.81 & 12.1 & 0.068 & 0.44 & & & & & 0.01 \\
\hline
\end{tabular}




\begin{tabular}{|c|c|c|c|c|c|c|c|c|c|c|}
\hline 11057 & 35.968410 & -77.048880 & 3384.28 & 9.1 & 0.061 & 0.43 & 2.14 & 1.11 & 1.54 & 979814.9 \\
\hline 11058 & 35.986480 & -77.020400 & 3386.16 & 11.9 & 0.053 & 0.44 & 3.44 & 2.09 & 2.53 & 979816.9 \\
\hline 11059 & 35.982670 & -77.001160 & 3386.66 & 9.4 & 0.047 & 0.43 & 3.50 & 2.44 & 2.87 & 979817.5 \\
\hline 11060 & 35.992420 & -76.974650 & 3388.47 & 10.1 & 0.040 & 0.43 & 4.80 & 3.65 & 4.08 & 979819.4 \\
\hline 11061 & 35.920140 & -77.017120 & 3380.4 & 7.4 & 0.131 & 0.42 & 1.79 & 0.95 & 1.37 & 979811.0 \\
\hline 11062 & 35.940230 & -77.025870 & 3381.7 & 8.7 & 0.134 & 0.43 & 1.82 & 0.84 & 1.27 & \begin{tabular}{|l|l|l}
9712.3 \\
\end{tabular} \\
\hline 11063 & 35.957940 & -77.026120 & 3384.16 & 8.1 & 0.137 & 0.42 & 2.72 & 1.80 & 2.22 & 979814.9 \\
\hline 11064 & 35.943580 & -77.042510 & 3382.76 & 7.0 & 0.139 & 0.42 & 2.13 & 1.33 & 1.75 & 979813.5 \\
\hline 11066 & 35.956160 & -77.068060 & 3383.02 & 8.0 & 0.142 & 0.42 & 1.61 & 0.71 & 1.13 & 979813.7 \\
\hline 11067 & 35.954540 & -77.079490 & 3383.46 & 4.5 & 0.142 & 0.39 & 1.12 & 0.62 & 1.01 & 979814.2 \\
\hline 11068 & 35.973530 & -77.085370 & 3386.14 & 12.9 & 0.141 & 0.44 & 4.93 & 3.47 & 3.90 & 979817.0 \\
\hline 11069 & 35.983650 & -77.094950 & 3389.96 & 12.0 & 0.140 & 0.43 & 7.80 & 6.45 & 6.88 & 979821.0 \\
\hline 11070 & 35.999370 & -77.108260 & 3396.17 & 12.7 & 0.139 & 0.43 & 13.23 & 11.79 & 12.23 & 979827.6 \\
\hline 11071 & 36.005440 & -77.121580 & 3400.06 & 12.8 & 0.138 & 0.43 & 16.86 & 15.41 & 15.84 & 979831.7 \\
\hline 11072 & 36.012100 & -77.135250 & 3401.41 & 12.5 & 0.136 & 0.43 & 17.61 & 16.19 & 16.62 & 979833.1 \\
\hline 11073 & 36.019990 & -77.144540 & 3401.64 & 13.7 & 0.134 & 0.45 & 17.54 & 15.99 & 16.44 & 979833.4 \\
\hline 11075 & 36.047070 & -77.163180 & 3403.67 & 13.2 & 0.128 & 0.45 & 17.18 & 15.68 & 16.13 & 979835.5 \\
\hline 11076 & 36.060160 & -77.178750 & 3403.18 & 10.9 & 0.125 & 0.44 & 14.81 & 13.58 & 14.02 & 979835.0 \\
\hline 11077 & 36.080510 & -77.191080 & 3400.16 & 14.7 & 0.121 & 0.45 & 11.03 & 9.37 & 9.82 & 979831.8 \\
\hline 11078 & 36.062530 & -77.201760 & 3400.74 & 8.2 & 0.117 & 0.43 & 11.18 & 10.25 & 10.68 & 979832.4 \\
\hline 11079 & 36.043120 & -77.211780 & 3399.79 & 7.1 & 0.112 & 0.42 & 11.51 & 10.70 & 11.12 & 979831.3 \\
\hline 11080 & 36.018310 & -77.210660 & 3400.38 & 7.2 & 0.105 & 0.42 & 14.29 & 13.46 & 13.89 & 979832.0 \\
\hline 11081 & 35.987970 & -77.241620 & 3390.77 & 24.7 & 0.099 & 0.47 & 12.10 & 9.31 & 9.77 & 979821.8 \\
\hline 11082 & 35.970590 & -77.219380 & 3395.01 & 24.3 & 0.094 & 0.47 & 17.96 & 15.20 & 15.67 & 979826.3 \\
\hline 11083 & 35.955930 & -77.216960 & 3394.26 & 25.3 & 0.088 & 0.47 & 18.70 & 15.84 & 16.30 & 979825.5 \\
\hline 11084 & 35.932600 & -77.201450 & 3392.18 & 21.6 & 0.081 & 0.46 & 17.36 & 14.91 & 15.37 & 979823.2 \\
\hline 11085 & 35.924860 & -77.180710 & 3392.31 & 14.7 & 0.074 & 0.45 & 16.03 & 14.36 & 14.81 & 979823.4 \\
\hline 11086 & 35.928150 & -77.162890 & 3389.43 & 20.5 & 0.068 & 0.46 & 14.46 & 12.14 & 12.60 & 979820.3 \\
\hline 11087 & 35.905710 & -77.146790 & 3382.43 & 10.4 & 0.060 & 0.44 & 5.86 & 4.68 & 5.12 & 979812.9 \\
\hline 11088 & 35.918480 & -77.127760 & 3378.52 & 23.3 & 0.052 & 0.45 & 4.62 & 1.97 & 2.42 & 979808.7 \\
\hline 11089 & 35.910060 & -77.104510 & 3376.18 & 13.2 & 0.044 & 0.44 & -0.27 & -1.77 & -1.33 & 979806.3 \\
\hline 11090 & 35.893090 & -77.129270 & 3378.84 & 6.5 & 0.037 & 0.41 & 1.91 & 1.18 & 1.59 & 979809.1 \\
\hline 11091 & 35.885030 & -77.098460 & 3375.69 & 8.8 & 0.028 & 0.42 & -0.04 & -1.03 & -0.61 & 979805.7 \\
\hline 11092 & 35.864010 & -77.043570 & 3377.02 & 1.8 & 0.066 & 0.36 & 1.00 & 0.80 & 1.15 & 979807.1 \\
\hline 11093 & 35.871090 & -77.073490 & 3375.23 & 18.2 & 0.086 & 0.46 & 3.58 & 1.51 & 1.97 & 979805.2 \\
\hline 11094 & 35.973110 & -77.084490 & 3374.55 & 13.0 & 0.090 & 0.44 & -7.52 & -8.99 & -8.55 & 979804.5 \\
\hline 11095 & 35.874170 & -77.107800 & 3372.39 & 23.6 & 0.096 & 0.45 & 1.97 & -0.70 & -0.25 & 979802.2 \\
\hline 11097 & 35.874700 & -77.139040 & 3374.15 & 19.1 & 0.104 & 0.45 & 2.42 & 0.26 & 0.70 & 979804.1 \\
\hline 11098 & 35.885360 & -77.154540 & 3374.4 & 20.5 & 0.110 & 0.46 & 2.19 & -0.13 & 0.33 & 979804.4 \\
\hline 11099 & 35.907810 & -77.206010 & 3391.22 & 12.6 & 0.116 & 0.45 & 15.61 & 14.19 & 14.64 & 979822.2 \\
\hline 11100 & 35.919880 & -77.206620 & 3391.83 & 18.0 & 0.119 & 0.46 & 16.90 & 14.86 & 15.32 & 979822.8 \\
\hline 11101 & 35.942600 & -77.228590 & 3393.35 & 23.3 & 0.124 & 0.47 & 18.19 & 15.55 & 16.02 & 979824.4 \\
\hline 11102 & 35.944910 & -77.246920 & 3391.31 & 23.0 & 0.128 & 0.47 & 15.75 & 13.15 & 13.61 & 979822.3 \\
\hline 11103 & 35.923760 & -77.269200 & 3385.47 & 17.3 & 0.132 & 0.46 & 9.63 & 7.67 & 8.13 & 979816.1 \\
\hline 11104 & 35.908090 & -77.235560 & 3390.08 & 22.2 & 0.135 & 0.47 & 17.39 & 14.87 & 15.33 & 979821.0 \\
\hline 11105 & 35.893780 & -77.241000 & 3387.85 & 20.5 & 0.138 & 0.46 & 15.72 & 13.40 & 13.86 & 979818.6 \\
\hline 11106 & 35.875120 & -77.241320 & 3384.47 & 22.3 & 0.140 & 0.47 & 14.31 & 11.78 & 12.25 & 979815.0 \\
\hline 11107 & 35.879440 & -77.225860 & 3385.66 & 20.1 & 0.141 & 0.46 & 14.52 & 12.24 & 12.70 & 979816.3 \\
\hline 11108 & 35.890400 & -77.208410 & 3387.25 & 20.5 & 0.141 & 0.46 & 15.39 & 13.06 & 13.52 & 979818.0 \\
\hline 11109 & 35.895600 & -77.190640 & 3387.13 & 14.6 & 0.142 & 0.45 & 12.97 & 11.32 & 11.77 & 979817.8 \\
\hline 11110 & 35.888490 & -77.174720 & 3381.85 & 18.5 & 0.142 & 0.46 & 9.21 & 7.12 & 7.57 & 979812.3 \\
\hline 11111 & 35.872930 & -77.174220 & 3377.78 & 19.8 & 0.141 & 0.46 & 6.64 & 4.40 & 4.86 & 979808.0 \\
\hline 11112 & 35.860510 & -77.120090 & 3373.43 & 19.0 & 0.140 & 0.45 & 2.85 & 0.70 & 1.15 & 979803.4 \\
\hline 11113 & 35.859920 & -77.098560 & 3372.97 & 23.1 & 0.138 & 0.45 & 3.70 & 1.08 & 1.53 & 979802.9 \\
\hline 11114 & 35.850830 & -77.084530 & 3374.18 & 23.7 & 0.137 & 0.45 & 5.93 & 3.25 & 3.70 & 979804.1 \\
\hline 11115 & 35.927100 & -77.001620 & 3383.41 & 7.4 & 0.129 & 0.42 & 4.09 & 3.26 & 3.68 & 979813.9 \\
\hline 11116 & 35.948950 & -76.956840 & 3382.19 & 8.0 & 0.125 & 0.42 & 1.14 & 0.22 & 0.64 & 979812.6 \\
\hline 11117 & 35.966650 & -76.952040 & 3385.23 & 9.8 & 0.122 & 0.43 & 3.36 & 2.25 & 2.68 & 979815.8 \\
\hline 11118 & 35.938040 & -76.972790 & 3383.24 & 8.6 & 0.004 & 0.42 & 3.29 & 2.31 & 2.73 & 979813.6 \\
\hline 11119 & 35.841060 & -77.081210 & 3373.79 & 24.1 & 0.016 & 0.45 & 6.40 & 3.67 & 4.12 & 979803.6 \\
\hline 11120 & 35.830760 & -77.096430 & 3371.32 & 23.4 & 0.021 & 0.45 & 4.45 & 1.81 & 2.26 & 979801.0 \\
\hline 11121 & 35.839690 & -77.109930 & 3372.08 & 23.1 & 0.026 & 0.45 & 4.41 & 1.79 & 2.24 & 979801.8 \\
\hline 11122 & 35.837310 & -77.162130 & 3369.2 & 21.6 & 0.033 & 0.46 & 1.11 & -1.34 & -0.88 & 979798.8 \\
\hline
\end{tabular}




\begin{tabular}{|c|c|c|c|c|c|c|c|c|c|c|}
\hline 11123 & 35.844540 & -77.150250 & 3369.93 & 22.5 & 0.037 & 0.46 & 1.55 & -1.00 & -0.54 & 979799.6 \\
\hline 11124 & 35.851260 & -77.133070 & 3372.9 & 17.3 & 0.040 & 0.44 & 2.49 & 0.54 & 0.98 & 979802.7 \\
\hline 11125 & 35.851900 & -77.158370 & 3371.29 & 21.0 & 0.046 & 0.46 & 1.89 & -0.49 & -0.03 & 979801.0 \\
\hline 11126 & 35.857720 & -77.175570 & 3374.23 & 22.2 & 0.050 & 0.46 & 4.87 & 2.36 & 2.82 & 979804.1 \\
\hline 11127 & 35.852640 & -77.197320 & 3378.72 & 12.9 & 0.054 & 0.45 & 7.20 & 5.74 & 6.19 & 979808.9 \\
\hline 11128 & 35.871670 & -77.199390 & 3382.58 & 18.6 & 0.058 & 0.46 & 11.40 & 9.30 & 9.75 & 979813.0 \\
\hline 11129 & 35.856960 & -77.219380 & 3381.34 & 16.8 & 0.064 & 0.46 & 10.80 & 8.90 & 9.36 & 979811.7 \\
\hline 11130 & 35.826890 & -77.196740 & 3373.3 & 12.3 & 0.071 & 0.45 & 3.48 & 2.10 & 2.54 & 979803.2 \\
\hline 11131 & 35.816110 & -77.223530 & 3372.6 & 19.8 & 0.075 & 0.46 & 6.01 & 3.76 & 4.22 & 979802.4 \\
\hline 11132 & 35.794180 & -77.210840 & 3369.63 & 10.9 & 0.080 & 0.44 & 1.98 & 0.75 & 1.20 & 979799.3 \\
\hline 11133 & 35.790040 & -77.229420 & 3369.68 & 19.2 & 0.082 & 0.46 & 4.98 & 2.80 & 3.26 & 979799.4 \\
\hline 11134 & 35.765540 & -77.224640 & 3368.37 & 10.9 & 0.087 & 0.45 & 3.13 & 1.89 & 2.34 & 979798.0 \\
\hline 11135 & 35.777380 & -77.202700 & 3367.42 & 11.8 & 0.089 & 0.44 & 1.40 & 0.06 & 0.50 & 979797.0 \\
\hline 11136 & 35.758380 & -77.194810 & 3365.01 & 12.6 & 0.091 & 0.45 & 0.70 & -0.72 & -0.28 & 979794.4 \\
\hline 11137 & 35.748180 & -77.168570 & 3359.92 & 11.4 & 0.093 & 0.44 & -4.15 & -5.45 & -5.00 & 979789.0 \\
\hline 11138 & 35.763040 & -77.166780 & 3360.95 & 13.1 & 0.095 & 0.45 & -3.82 & -5.31 & -4.86 & 979790.1 \\
\hline 11139 & 35.773490 & -77.176010 & 3363.43 & 13.9 & 0.096 & 0.45 & -1.85 & -3.42 & -2.98 & 979792.7 \\
\hline 11140 & 35.790980 & -77.182810 & 3365.19 & 18.1 & 0.098 & 0.46 & -0.18 & -2.24 & -1.78 & 979794.6 \\
\hline 11141 & 35.809760 & -77.179450 & 3367.43 & 16.3 & 0.099 & 0.45 & 0.01 & -1.84 & -1.38 & 979797.0 \\
\hline 11142 & 35.819950 & -77.153010 & 3366.98 & 22.3 & 0.099 & 0.46 & 0.51 & -2.02 & -1.56 & 979796.5 \\
\hline 11143 & 35.798820 & -77.153340 & 3363.5 & 22.6 & 0.099 & 0.46 & -1.27 & -3.83 & -3.37 & 979792.8 \\
\hline 11144 & 35.778190 & -77.151290 & 3361.47 & 15.9 & 0.099 & 0.45 & -3.71 & -5.51 & -5.06 & 979790.7 \\
\hline 11145 & 35.792490 & -77.136710 & 3363.05 & 21.7 & 0.098 & 0.45 & -1.48 & -3.94 & -3.49 & 979792.3 \\
\hline 11146 & 35.791480 & -77.125830 & 3363.24 & 21.8 & 0.098 & 0.45 & -1.16 & -3.63 & -3.18 & 979792.5 \\
\hline 11147 & 35.807910 & -77.126130 & 3367.1 & 22.0 & 0.097 & 0.45 & 1.57 & -0.93 & -0.48 & 979796.6 \\
\hline 11148 & 35.824920 & -77.133490 & 3368.67 & 22.9 & 0.095 & 0.45 & 2.03 & -0.56 & -0.11 & 979798.3 \\
\hline 11149 & 35.829360 & -77.077950 & 3371.51 & 21.9 & 0.093 & 0.45 & 4.35 & 1.87 & 2.32 & 979801.3 \\
\hline 11150 & 35.828260 & -77.065720 & 3371.3 & 21.1 & 0.090 & 0.46 & 3.96 & 1.58 & 2.03 & 979801.0 \\
\hline 11151 & 35.805410 & -77.088460 & 3365.92 & 22.0 & -0.025 & 0.45 & 0.38 & -2.12 & -1.67 & 979795.2 \\
\hline 11152 & 35.812770 & -77.102890 & 3367.94 & 22.9 & -0.023 & 0.45 & 2.14 & -0.45 & 0.00 & 979797.3 \\
\hline 11153 & 35.797140 & -77.113610 & 3366.63 & 15.7 & -0.020 & 0.44 & -0.11 & -1.89 & -1.45 & 979796.0 \\
\hline 11154 & 35.784180 & -77.120350 & 3360.87 & 23.2 & -0.017 & 0.45 & -2.79 & -5.41 & -4.96 & 979789.9 \\
\hline 11155 & 35.766230 & -77.145810 & 3359.26 & 15.3 & -0.012 & 0.45 & -5.37 & -7.10 & -6.65 & 979788.2 \\
\hline 11156 & 35.755600 & -77.139960 & 3357.49 & 14.1 & -0.009 & 0.44 & -6.71 & -8.30 & -7.86 & 979786.3 \\
\hline 11157 & 35.746040 & -77.139290 & 3356.47 & 12.2 & -0.006 & 0.43 & -7.53 & -8.92 & -8.48 & 979785.2 \\
\hline 11158 & 35.731480 & -77.135740 & 3354.49 & 14.5 & -0.002 & 0.44 & -7.66 & -9.31 & -8.87 & 979783.1 \\
\hline 11159 & 35.723850 & -77.121910 & 3352.62 & 17.7 & 0.003 & 0.45 & -8.00 & -10.01 & -9.56 & 979781.2 \\
\hline 11160 & 35.739400 & -77.124000 & 3356.02 & 10.6 & 0.008 & 0.43 & -7.94 & -9.14 & -8.71 & 979784.8 \\
\hline 11161 & 35.753420 & -77.124170 & 3356.25 & 17.3 & 0.011 & 0.44 & -6.81 & -8.78 & -8.33 & 979785.0 \\
\hline 11162 & 35.766400 & -77.126260 & 3357.92 & 18.0 & 0.015 & 0.44 & -5.95 & -7.99 & -7.54 & 979786.8 \\
\hline 11163 & 35.746690 & -77.107930 & 3354.73 & 18.9 & 0.020 & 0.45 & -7.36 & -9.50 & -9.05 & 979783.4 \\
\hline 11164 & 35.735860 & -77.109820 & 3354.34 & 14.2 & 0.023 & 0.44 & -8.27 & -9.88 & -9.44 & 979783.0 \\
\hline 11165 & 35.742030 & -77.086850 & 3354.63 & 16.2 & 0.028 & 0.44 & -7.88 & -9.72 & -9.27 & 979783.3 \\
\hline 11166 & 35.719670 & -77.073640 & 3351.66 & 17.0 & 0.032 & 0.46 & -8.86 & -10.78 & -10.33 & 979780.2 \\
\hline 11167 & 35.753270 & -77.075390 & 3355.17 & 20.9 & 0.038 & 0.46 & -6.82 & -9.19 & -8.73 & 979783.9 \\
\hline 11168 & 35.770190 & -77.082450 & 3357.93 & 20.8 & 0.042 & 0.45 & -5.36 & -7.72 & -7.28 & 979786.8 \\
\hline 11169 & 35.775500 & -77.100920 & 3359.37 & 17.4 & 0.045 & 0.44 & -5.34 & -7.31 & -6.87 & 979788.3 \\
\hline 11170 & 35.791060 & -77.077800 & 3363.52 & 13.3 & 0.050 & 0.44 & -3.57 & -5.07 & -4.63 & 979792.7 \\
\hline 11171 & 35.786960 & -77.058570 & 3364.14 & 8.5 & 0.053 & 0.43 & -4.04 & -5.00 & -4.57 & 979793.4 \\
\hline 11172 & 35.801180 & -77.056850 & 3365.4 & 11.7 & 0.056 & 0.44 & -2.91 & -4.24 & -3.80 & 979794.7 \\
\hline 11173 & 35.806020 & -77.036550 & 3370.46 & 6.4 & 0.059 & 0.42 & 0.36 & -0.36 & 0.06 & 979800.1 \\
\hline 11174 & 35.822640 & -77.013010 & 3372.7 & 8.9 & 0.063 & 0.43 & 2.09 & 1.09 & 1.52 & 979802.4 \\
\hline 11175 & 35.811800 & -76.975510 & 3364.39 & 9.0 & 0.066 & 0.43 & -5.73 & -6.75 & -6.32 & 979793.7 \\
\hline 11176 & 35.807790 & -76.941290 & 3361.21 & 9.4 & 0.069 & 0.43 & -8.63 & -9.69 & -9.27 & 979790.3 \\
\hline 11177 & 35.811790 & -76.856310 & 3365.75 & 13.9 & 0.072 & 0.45 & -2.76 & -4.34 & -3.90 & 979795.1 \\
\hline 11178 & 35.808340 & -76.887410 & 3363.83 & 11.0 & 0.076 & 0.44 & -5.41 & -6.65 & -6.21 & 979793.1 \\
\hline 11179 & 35.821840 & -76.902890 & 3365.34 & 1.4 & 0.077 & 0.35 & -7.93 & -8.09 & -7.74 & 979794.7 \\
\hline 11180 & 35.811970 & -76.932110 & 3362.79 & 3.5 & 0.078 & 0.39 & -9.11 & -9.51 & -9.12 & 979792.0 \\
\hline 11181 & 35.809200 & -76.961850 & 3362.92 & 7.6 & 0.078 & 0.42 & -7.50 & -8.35 & -7.93 & 979792.1 \\
\hline 11182 & 35.828180 & -76.957500 & 3366.31 & 2.6 & 0.078 & 0.37 & -7.07 & -7.36 & -6.99 & 979795.7 \\
\hline 11183 & 35.820810 & -76.956500 & 3365.35 & 1.5 & 0.078 & 0.35 & -7.79 & -7.96 & -7.62 & 979794.7 \\
\hline 11184 & 35.831170 & -76.975730 & 3368.62 & 2.2 & 0.078 & 0.36 & -5.01 & -5.26 & -4.89 & 979798.1 \\
\hline 11185 & 35.844760 & -76.984680 & 3371.25 & 2.1 & 0.077 & 0.36 & -3.43 & -3.67 & -3.31 & 979800.9 \\
\hline
\end{tabular}




\begin{tabular}{|c|c|c|c|c|c|c|c|c|c|c|}
\hline 11186 & 35.818040 & -76.999580 & 3369.64 & 8.7 & 0.076 & 0.42 & -0.80 & -1.79 & -1.36 & 979799.2 \\
\hline 11187 & 35.834250 & -77.002180 & 3372.76 & 1.8 & 0.074 & 0.36 & -1.02 & -1.22 & -0.87 & 979802.5 \\
\hline 11188 & 35.852590 & -77.032690 & 3375.33 & 3.7 & 0.071 & 0.39 & 0.69 & 0.28 & 0.67 & 979805.2 \\
\hline 11189 & 36.003340 & -76.981990 & 3389.12 & 10.0 & -0.029 & 0.43 & 4.21 & 3.08 & 3.51 & 979819.8 \\
\hline 11190 & 35.966950 & -76.995340 & 3386.18 & 10.1 & -0.028 & 0.43 & 4.26 & 3.12 & 3.55 & 979816.6 \\
\hline 11191 & 35.956220 & -76.979850 & 3385.78 & 9.9 & -0.025 & 0.43 & 4.72 & 3.60 & 4.02 & 979816.2 \\
\hline 11192 & 35.941370 & -76.931140 & 3378.58 & 1.7 & -0.022 & 0.36 & -4.14 & -4.34 & -3.98 & 979808.6 \\
\hline 11193 & 35.933560 & -76.910790 & 3376.2 & 5.6 & -0.020 & 0.41 & -4.80 & -5.43 & -5.02 & 979806.1 \\
\hline 11195 & 35.899040 & -76.841350 & 3369.17 & 5.6 & -0.015 & 0.41 & -9.26 & -9.89 & -9.48 & 979798.7 \\
\hline 11196 & 35.910930 & -76.817000 & 3368.89 & 0.7 & -0.012 & 0.33 & -12.08 & -12.16 & -11.83 & 979798.4 \\
\hline 11197 & 35.916260 & -76.861470 & 3372.87 & 6.2 & -0.009 & 0.41 & -6.62 & -7.32 & -6.91 & 979802.6 \\
\hline 11198 & 35.924300 & -76.848630 & 3371.4 & 7.0 & -0.006 & 0.42 & -8.63 & -9.42 & -9.00 & 979801.0 \\
\hline 11199 & 35.901530 & -76.867340 & 3372.45 & 6.9 & -0.003 & 0.42 & -5.59 & -6.37 & -5.95 & 979802.2 \\
\hline 11200 & 35.896100 & -76.890220 & 3373.64 & 7.2 & -0.001 & 0.42 & -3.77 & -4.58 & -4.16 & 979803.4 \\
\hline 11201 & 35.900730 & -76.909980 & 3373.07 & 6.7 & 0.001 & 0.42 & -4.93 & -5.68 & -5.27 & 979802.8 \\
\hline 11202 & 35.916440 & -76.908760 & 3374.54 & 6.5 & 0.003 & 0.42 & -4.76 & -5.50 & -5.09 & 979804.4 \\
\hline 11203 & 35.921000 & -76.939260 & 3375.23 & 7.6 & 0.013 & 0.42 & -4.07 & -4.94 & -4.52 & 979805.1 \\
\hline 11204 & 35.909550 & -76.942160 & 3374.08 & 8.0 & 0.016 & 0.42 & -4.19 & -5.09 & -4.68 & 979803.9 \\
\hline 11205 & 35.911030 & -76.963910 & 3376.78 & 7.1 & 0.018 & 0.41 & -1.73 & -2.54 & -2.12 & 979806.8 \\
\hline 11206 & 35.902420 & -76.994890 & 3379.74 & 7.0 & 0.022 & 0.41 & 2.10 & 1.31 & 1.73 & 979809.9 \\
\hline 11207 & 35.988530 & -76.926040 & 3386.89 & 7.2 & 0.040 & 0.42 & 2.34 & 1.52 & 1.94 & 979817.5 \\
\hline 11208 & 35.979700 & -76.912150 & 3382.25 & 9.5 & 0.041 & 0.43 & -1.11 & -2.18 & -1.75 & 979812.6 \\
\hline 11209 & 35.976460 & -76.899980 & 3381.1 & 7.9 & 0.043 & 0.42 & -2.53 & -3.42 & -3.00 & 979811.3 \\
\hline 11210 & 35.957190 & -76.866540 & 3375.98 & 7.7 & 0.046 & 0.42 & -6.36 & -7.23 & -6.80 & 979805.9 \\
\hline 11211 & 35.952190 & -76.840330 & 3371.91 & 9.7 & 0.047 & 0.43 & -9.60 & -10.70 & -10.27 & 979801.6 \\
\hline 11212 & 35.936000 & -76.807390 & 3368.11 & 11.5 & 0.049 & 0.44 & -11.66 & -12.97 & -12.53 & 979797.6 \\
\hline 11213 & 35.925460 & -76.787440 & 3367.07 & 9.8 & 0.050 & 0.44 & -12.39 & -13.51 & -13.06 & 979796.5 \\
\hline 11214 & 35.929310 & -76.772260 & 3367.14 & 10.2 & 0.051 & 0.44 & -12.52 & -13.68 & -13.24 & 979796.6 \\
\hline 11215 & 35.942380 & -76.819250 & 3369.18 & 10.0 & 0.053 & 0.43 & -11.55 & $\begin{array}{l}-12.69 \\
\end{array}$ & -12.26 & 979798.7 \\
\hline
\end{tabular}

\section{Inverse Modeling}

Modeling of the data suggests the basin is elongate, generally SW to NE, and is approximately $15 \mathrm{~km}$ wide, $50 \mathrm{~km}$ long, and as much as $2.5 \mathrm{~km}$ deep. The buried basin creates a maximum gravity anomaly between 7 to $10 \mathrm{mGal}$ (Figure 37 ). The western margin of the basin is bounded by a ridge oriented parallel to the basin and on trend with a ridgeline from which a crystalline monadnock protrudes out of the Coastal Plain sediments in Fountain, NC. This ridge may represent the uplifted footwall of the main bounding fault of the basin. The eastern margin is also bounded by a ridge but has a smaller gravity anomaly of approximately $5 \mathrm{mGal}$ and seems broken or discontinuous further to the south. The breaks in the eastern ridge could represent hydrogeologic openings that allowed water to pass thru the basin during its formation. 


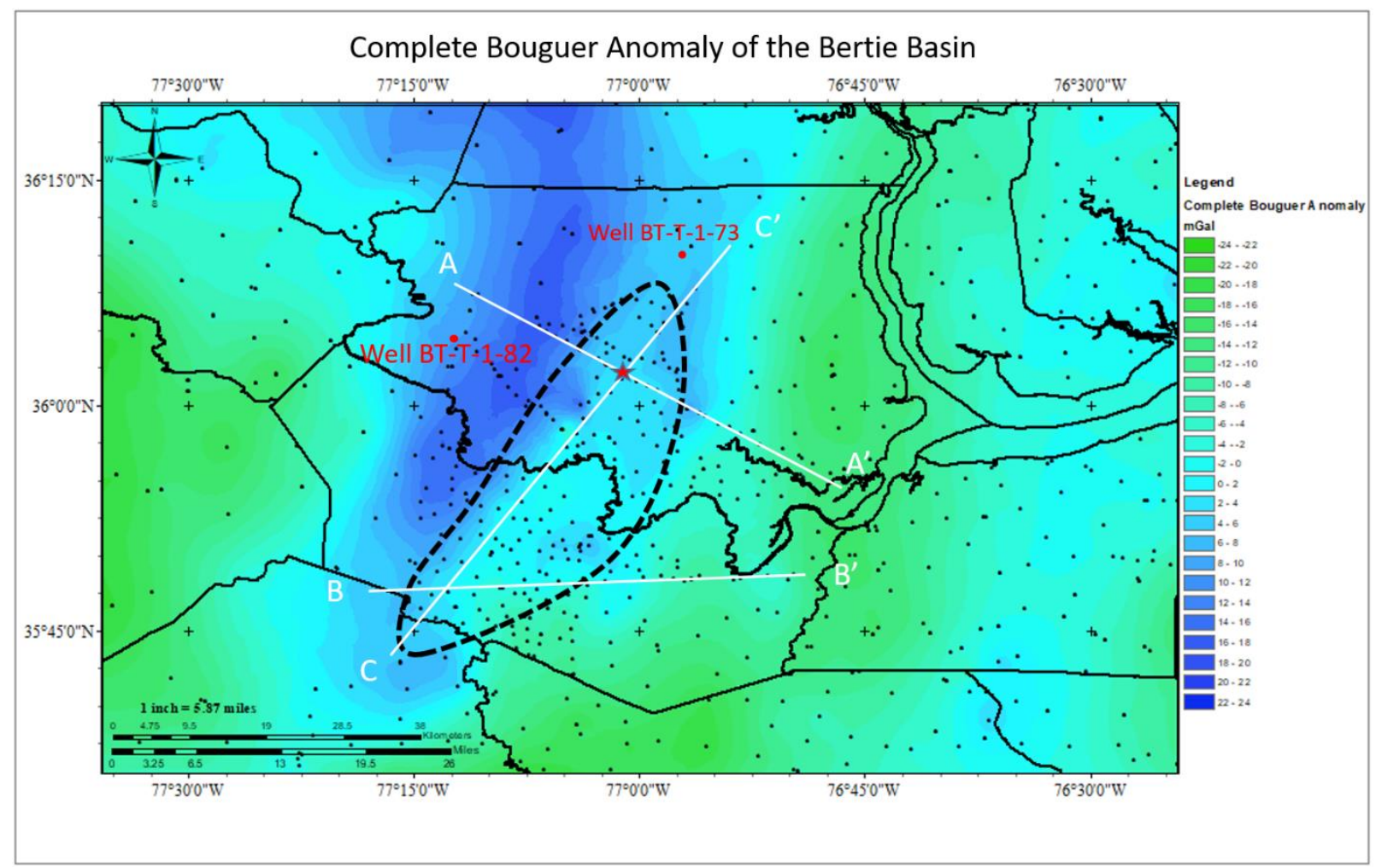

Figure 37: Complete Bouguer contour map of study site and surrounding areas. Points are observation stations from the gravity survey and PACES database. Lines show transects used for cross-sections during inverse modeling. Dotted line represents approximate boundaries of the Bertie basin. Red dots are location of wells that reach basement rock. Red star is the location of the Hope Plantation.

East and south of the eastern margin is a negative gravity anomaly of approximately 20 $\mathrm{mGal}$. This area coincides with north/south magnetic lineaments that may be explained by a duplex system along a fault zone separating lithologic belts, a syncline/anticline style of deformation, domino-style faulting that occurred during the main rifting event, or mafic igneous intrusions of unknown density and depth. It remains unclear if this bordering anomaly is associated with rifting and/or caused by some other process. If this anomaly is part of a series of basins resulting from sequential faulting, the larger magnitude suggests that it may be larger and deeper than the Bertie basin.

The northern termination point of the basin is in north-central Bertie County where both marginal ridges generally converge. Well BT-T-1-73 reached basement rock near this area at an altitude of $-988 \mathrm{ft}$ with no indication of Triassic strata. The southern termination point is in 
south-central Martin County, does not have converging margins, and is the deepest part of the basin. The Bouguer anomaly in this area becomes more negative and smoothly transitions southeasterly into the adjacent negative anomaly. This also supports the idea of a hydrogeologically open basin in which water flowed southward and emptied into a deeper basin. South of the basin, previous work based upon geophysical surveys has interpreted an east/west oriented anomaly as a fault, identified as the Roanoke Island-Goldsboro fault (Lawrence and Hoffman, 1993). Although this fault does not contact the basin, its proximity and/or dextral motion could have affected the basins original geometry.

In cross section, the basis is asymmetrical and wedge-shaped, with a NW margin that dips steeply SE and a SE margin that dips more shallowly NW. Figure 38 shows a cross-section from A to A', oriented generally northeast to southwest, across the northern extent of the Bertie basin and adjacent gravity anomaly to the east. A regional anomaly of $-0.14 \mathrm{mGal} / \mathrm{km}$ caused by the dipping basement surface and thickening Coastal Plain cover was modeled and corrected for based on Lawrence and Hoffman's (1993) interpretative geologic map of basement rock depth and dip. Because rift basins often form along inherited structures, north-south trending magnetic lineaments were interpreted to be a duplex system that was reactivated in a domino-style mechanism of faulting that dips seaward producing a series of basins. Densities of $1.9 \mathrm{~g} / \mathrm{cm}^{3}$, $2.35 \mathrm{~g} / \mathrm{cm}^{3}$, and $2.67 \mathrm{~g} / \mathrm{cm}^{3}$ were assumed for the Coastal Plain sedimentary strata, Triassic sedimentary units, and crystalline basement rock, respectively. This configuration gives an error of 0.182 between measured and calculated anomalies. The minimal error is representative of how closely the modeled gravitational anomaly matches the measured anomaly from the gravity survey. In this case, the small error means the model could be a close approximation of subsurface features. Non-uniqueness of gravity surveys infers there could be many 
configurations that are close matches with small errors, however. Modeled maximum thickness of the Bertie basin along this transect was approximately $1 \mathrm{~km}$ in the vicinity of the Hope Plantation. A significant anomaly also exists near the center of the basin that might be explained by half-graben geometry or displacement along fault blocks.

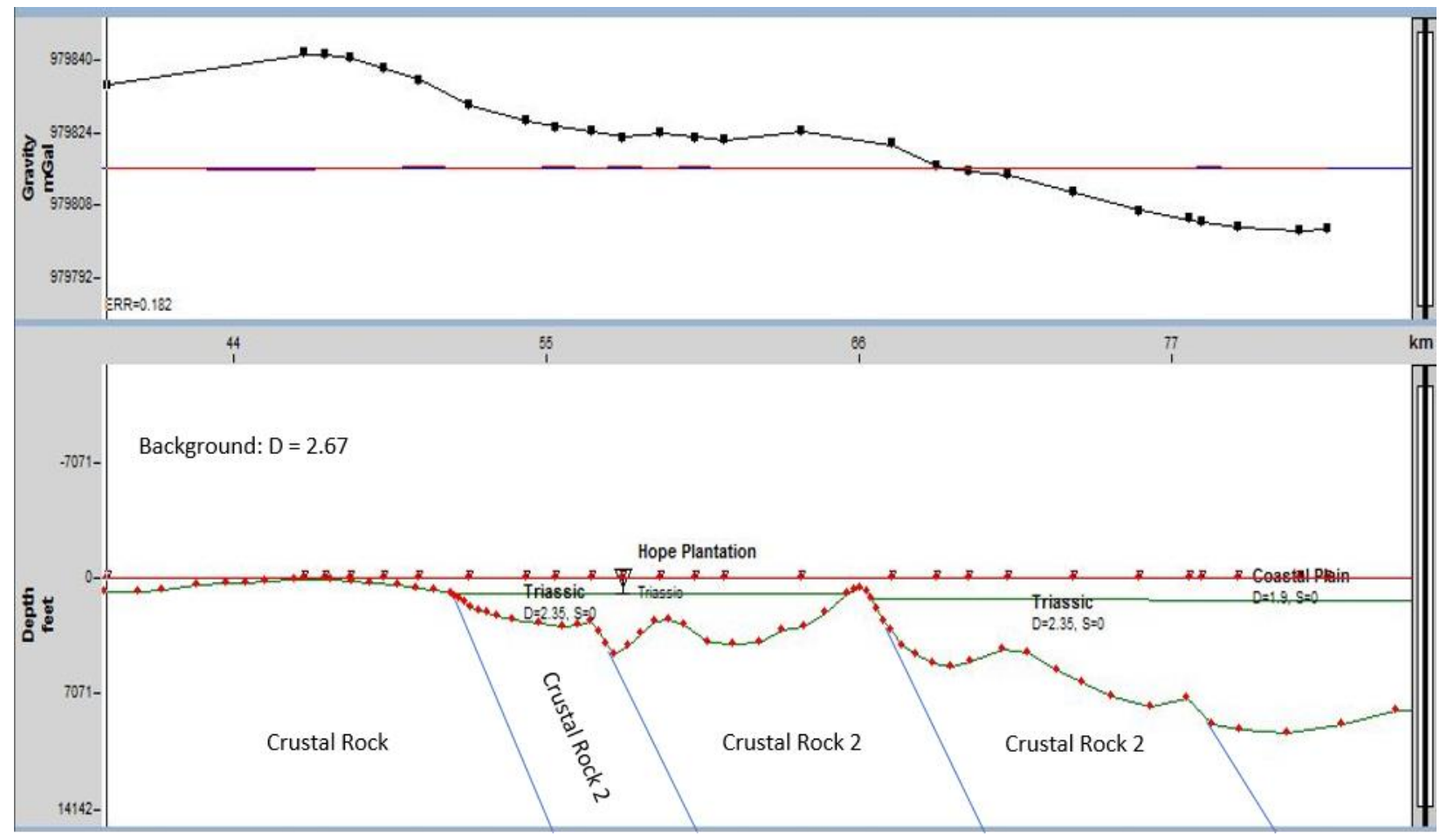

Figure 38: Cross-sectional view and gravity anomaly for transect A to A'. The Bertie basin is on the left centered around the Hope Plantation with a maximum depth of approximately $1 \mathrm{~km}$. Vertical exaggeration approximately $2 \mathrm{x}$

Figure 39 shows a cross-section from B to B', oriented generally east-west across the southern extent of the Bertie basin and adjacent gravity anomaly to the east. The regional anomaly, $-0.13724 \mathrm{mGal} / \mathrm{km}$, was calculated and corrected for in the same manner as in transect A to A'. The same densities and parameters were also used for this transect. This configuration gives an error of 0.192 between measured and calculated anomalies and a maximum depth of 2.0 $\mathrm{km}$ for the basin. A similar anomaly also exists near the center of the basin, as in transect A to A', supporting the possibility of half-graben formation. Similar gravity anomalies between 
transects also align east of the basin within the adjacent negative $20 \mathrm{mGal}$ anomaly suggesting a series of north-south striking fault blocks produced by domino-style faulting.

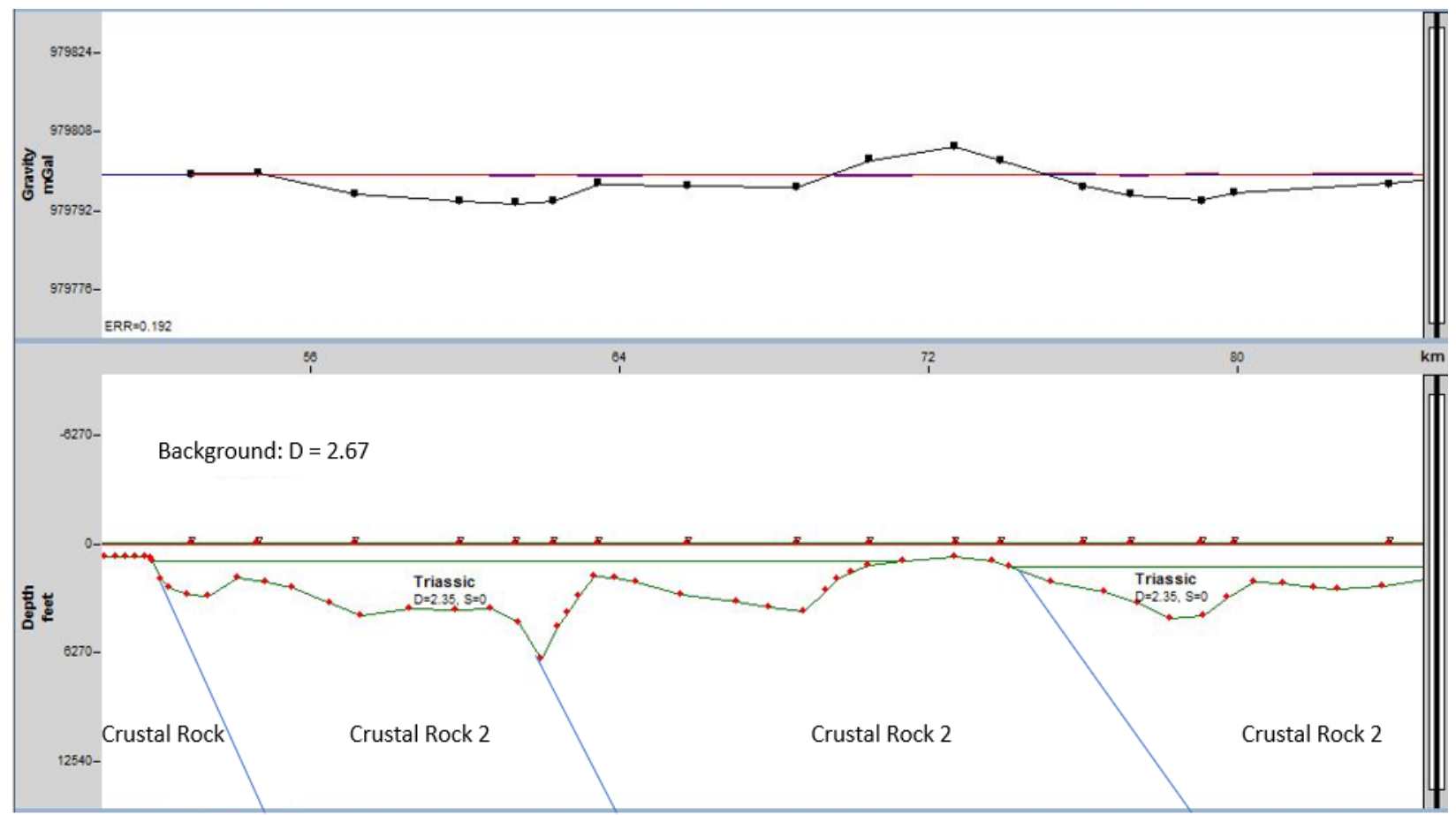

Figure 39: Cross-sectional view and gravity anomaly for transect B to B'. A maximum depth of approximately 2 $\mathrm{km}$ was calculated from the model. Vertical exaggeration approximately $2 \mathrm{x}$

Figure 40 shows a cross-section from $\mathrm{C}$ to C', oriented generally northeastsouthwest, through the center of the Bertie basin. Because this transect is generally oriented along strike to the dipping basement, a very small regional anomaly of $-0.02781 \mathrm{mGal} / \mathrm{km}$ was calculated. The same densities and parameters as in transect A to A' were used for this transect. This configuration gives an error of 0.258 between measured and calculated anomalies and a maximum depth of approximately $2.5 \mathrm{~km}$ for the modeled basin. The Bertie basin deepens to the south in a step-like manner with several corresponding anomalies in the modeled subsurface. It is 
possible the anomalous signatures are caused by the same feature as in the other transects, but with transect $\mathrm{C}$ to $\mathrm{C}^{\prime}$ aligned so that it crosses back and forth repeatedly along this feature.

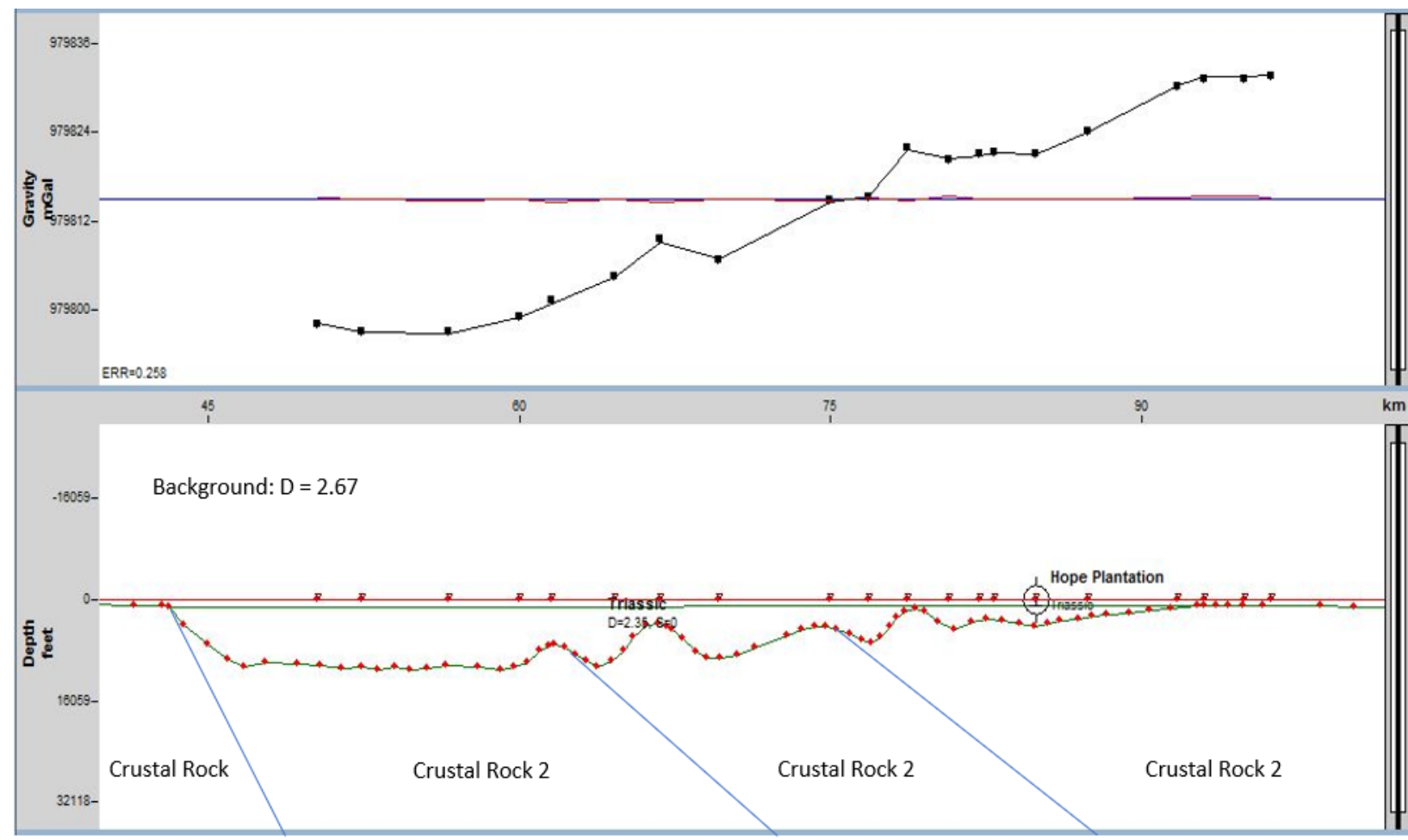

Figure 40: Cross-sectional view and gravity anomaly for transect $C$ to $C^{\prime}$. The basin model deepens to the south and has a maximum depth of approximately $2.5 \mathrm{~km}$. In the area of the Hope Plantation, the deepest portion of the basin is approximately $1 \mathrm{~km}$, similar to transect AA'. Vertical exaggeration approximately $2 \mathrm{x}$

Even with the regional anomalies corrected for, the modeled basin thickness is on the large side of what would be expected for a basin of its length and width. Changing the range of density values between Triassic and Coastal Plain strata within real-world values are not enough to significantly shallow the basin and maintain a good fit in the models. The only feasible mechanism to achieve significant shallowing is to assume a density difference between crustal blocks to the east and west of the main bounding fault that becomes sub-horizontal at some depth well below the modeled cross-section. Two wells that reached basement rock in Bertie County demonstrate that rock suites vary on either side of the basin bounding fault. Although shown in the cross-sectional models as two different crustal types, density was not varied for the models due to lack of information on real-world densities or known depths of faulting. Further 
supporting this idea, however, is that the basin is on trend with a linear feature to the south that separates high and low relief magnetic anomalies identified by Lawrence and Hoffman (1993) and interpreted as a possible unnamed fault underneath Coastal Plain sediment. 


\section{Chapter 11: Discussion}

The NA rift margin has been one of the most heavily studied rift margins in the world. Exposed and offshore basins are relatively well known due to geophysical surveys and drilling. In between these two areas, however, lies the Coastal Plain which conceals Triassic rift basins related to the NA rift margin and its evolution. The lack of deep cores reaching basement rock within the Coastal Plain has likely left many Triassic rift basins undiscovered, restricting understanding and paleo-reconstructions of the NA rift margin.

A newly discovered Triassic rift basin buried underneath coastal plain sediments and sedimentary rock has recently been identified in Bertie County, North Carolina. The Bertie basin is located within the Southern Segment of the NA rift margin suggesting that its geometry and stratigraphy should reflect regional trends and exhibit characteristics similar to other southern rift basins. Southern basins display type B or BB basin geometry, which is defined as narrow to medium size (10 to $25 \mathrm{~km}$ across) fault-bounded, half-graben basins with no or very subtle growth structures (Leleu et al., 2016). In most NA rift margin basins, the footwall is only slightly uplifted while the hanging wall undergoes most of the movement along the detachment fault. In half-graben basins like Type $\mathrm{B}$, the hanging walls margin is most commonly represented by antithetic faults with minor rotation (Schlische, 1993).

The NA rift margin started to form in the mid-to late- Triassic as Pangea began to rift and drift apart. The earliest thinning and extension began in present-day Virginia in an area that extends southward to the Roanoke-Island Goldsboro fault in North Carolina, and northward to Maryland. Within this extent, deformation seems to have undergone uniform plane strain with little complications from oblique or rotational movement resulting in the reactivation of Paleozoic structures. It is likely the main bounding fault of the Bertie basin is a reactivated Paleozoic 
structure, although it remains undetermined if the basin exists along an inherited framework or fault system.

The Bertie Basin is small compared to other exposed rift basins in North Carolina such as the Durham/Deep River and Danville Basins. Although oriented similarly, its more seaward position indicates that formation began later into the rifting event and occurred over a relatively short time period related to increased rates of rift migration. The increased extensional rates resulted in a reduced size, increased accommodation space oceanward, and the presence of growth structures less likely within the stratigraphy. Burial underneath the Coastal Plain, however, may have helped to preserve the Bertie Basin's original geometry and size which allows for better constraints on initial tectonic conditions, sedimentary deposition, and paleo-environments. Uplift in the proximal domain effecting exposed basins resulted in significant post-rift deformation through erosion and inversion.

Across-strike to the rift margin, the Bertie basin likely exists near the transition between the proximal and necking domains and may have properties consistent with both. It is positioned significantly eastward of exposed basins in the Piedmont and significantly westward of the ECGA, or hinge zone, where extension increases significantly and basement rocks dip steeply oceanward. Extension in the area of the Bertie basin is likely closer to $\beta$ values found in the proximal domain than the necking domain, although burial beneath the Coastal Plain suggests subsidence played a larger role in the basin's development than other exposed Triassic basins in North Carolina.

Lawrence and Hoffman (1993) used boreholes and geophysical methods to create an interpretive structure contour map of the Coastal Plain basement surface and used lithologic characteristics and tectonic features to group the basement rocks into five major regions. Bertie 
County is deemed part of the Roanoke Rapids terrane which makes up the dominant portion of the North Carolina Coastal Plain basement (Figure 25). The Roanoke Rapids terrane extends from the Virginia state line in the north to the inferred Pender fault system in the south. It is bordered on the west by the Spring Hope terrane, separated by the Hollister fault system, and on the east by the Hatteras terrane. Magnetic anomalies just east of the Hollister fault resemble those found in the Carolina slate belts in the eastern Piedmont and similar geologic sections are inferred for the Coastal Plain basement. It is likely that the Roanoke Rapids terrane is part of the same amalgamated peri-Gondwanan island arc that makes up the Carolina Zone.

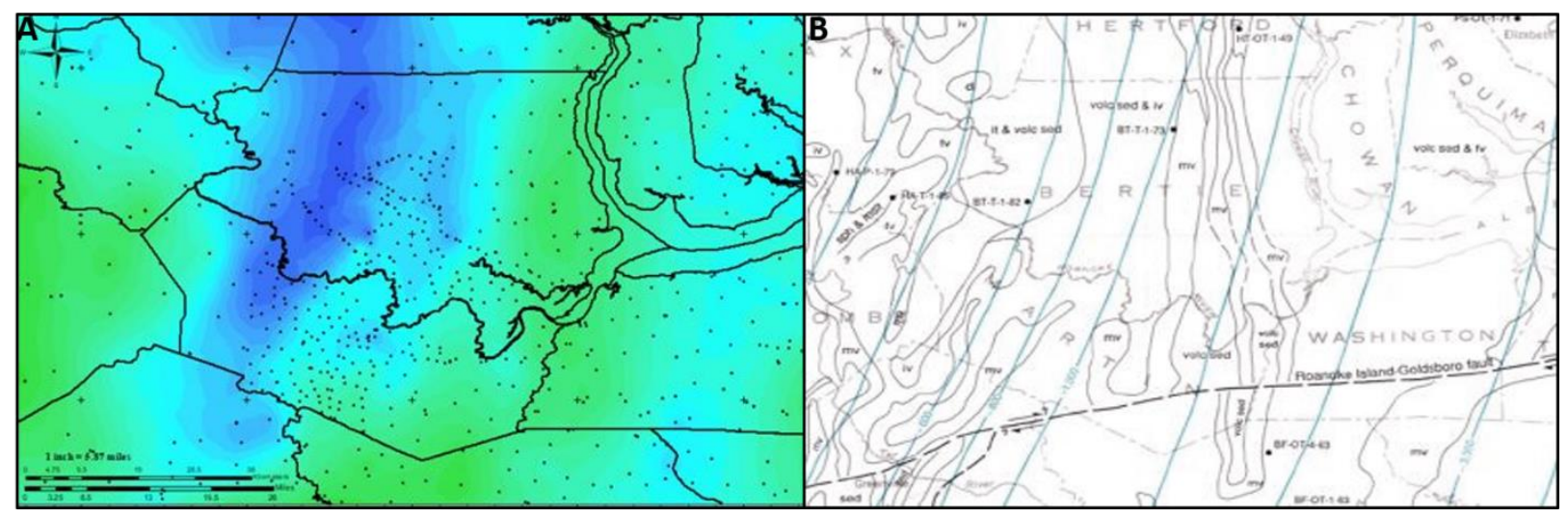

Figure 41: Side-by-side view of the complete Bouguer anomaly map with Lawrence and Hoffman's (1993) interpretive geologic map centered on Bertie County and the surrounding area.

East of a north-south trending line running through central Bertie County, basement rock consists of wide bands of low magnetic relief interspersed with narrow bands of highly magnetic rocks (Figure 41). Elongate positive gravity anomalies of 20 milligals were assumed to indicate possible belts of mafic volcanics. Figure X shows Lawrence and Hoffman's structure contour map overlain on the complete Bouguer anomaly map produced during this project. The belts of mafic volcanics align with ridges of the Bertie basin and match anomalies from the crosssectional profiles. This area has been interpreted as metamorphosed sedimentary rocks and felsic volcanics with narrow bands of mafic metavolcanics rocks (Lawrence and Hoffman, 1993), but a 
more likely interpretation is that the lineaments are produced by domino-style faulting and represent higher elevations of tilted fault blocks. South of the Bertie basin, patterns of truncated magnetic anomalies running east-west under Roanoke Island, Greenville, and Goldsboro indicates a fault, informally named the Roanoke Island-Goldsboro fault (Lawrence and Hoffman, 1993). The Roanoke Island-Goldsboro fault does not contact the basin, but its proximity and/or dextral motion could have affected the basins original geometry.

Layered rocks between the Hollister fault zone and a north-south line that approximately runs through Greenville, NC, are predominantly felsic to mafic volcanic rocks with minor metamudstone, metasiltsone, and volcaniclastic metasandstones (Lawrence and Hoffman, 1993). In a belt east of this line, the opposite is true with compositions of predominantly metamudstones and metasiltstones with minor metavolcanics rocks. This boundary between volcanic-rich and volcanic-poor rock suites has previously been interpreted as a Triassic basin (Daniels and Zietz, 1978) or a possible fault (Daniels and Leo, 1985). Lawrence and Hoffman (1993) interpreted this boundary as a possible unnamed fault that generally runs north-south on trend with a $110 \mathrm{~km}$ long magnetic unit thru Pitt, Lenoir, and Duplin counties. This fault may terminate at the Roanoke Island-Goldsboro fault or possibly continue past it to the north with some dextral offset. If so, this same unnamed fault could potentially represent the main bounding fault of the Bertie basin.

Lawrence and Hoffman (1993) identified two boreholes, BT-T-1-73 and BT-T-1-82, that reach basement rock in Bertie County. BT-T-1-73 is northeast of the basin and presumably infiltrates the hanging wall of the basin. Thin section analysis from drill core indicate a metamudstone with slaty cleavage likely of volcaniclastic origin. Petrographic description consists primarily of quartz silt grains, white mica, minor chlorite, and carbonate in thin veins. 
Minor opaques are mostly magnetite with less pyrite. BT-T-1-82 is west of the basin and presumably infiltrates the foot wall of the basin. Thin section analysis from cores are of unfoliated metavolcanic rock comprising an intermediate crystal-tuff. Petrographic description indicates epidote and plagioclase that show a relict volcanic texture. Also present are metamorphic carbonate, white mica, quartz, and chlorite with very minor magnetite and rutile.

The Hope Plantation test hole (BE-110-2004) in Bertie County, North Carolina, was cored on the property of the Hope Plantation west of Windsor, North Carolina. The stated goal of the Hope Plantation project was to collect a lithostratigraphic summary, along with geophysical logs, site core photographs, calcareous nannofossil biostratigraphy, and initial hydrogeologic interpretations. The Triassic material is stated to range from a depth of $1026 \mathrm{ft}$ to $1094.5 \mathrm{ft}$, however this interval is poorly constrained as there is no definitive transition from the Cretaceous to the Triassic. Crystalline basement rock was not reached, leaving the overall depth of the basin undetermined.

The USGS open file report contains descriptions of core recovered from well BE-1102004. Shifts in both gamma and resistivity logs at a depth of $1026 \mathrm{ft}$ are attributed to a major change in lithology. Core taken from below $1026 \mathrm{ft}$ ranges from angular to sub-rounded conglomerate, very coarse to fine quartz sandstone, and clayey siltstone. A dark red to brown ferruginous matrix is abundant. Clast mineralogy includes chloritic, schistose quartz, ferruginous sandstone, and diabase (Weems et al., 2007).

For this project, previous datasets have been derived from analysis of the cores at the NCGS by Ryan Poythress (unpublished), and include thin sections, whole rock geochemical analysis, and magnetic susceptibility. Although the cores contain less than $100 \mathrm{ft}$ of Triassic strata, these datasets can be used to constrain depositional history, provenance, tectonic facies, 
and mineral content of the Bertie basin. Analysis of the datasets suggest the provenance of the Triassic strata is a continental island arc that has undergone an orogenic event, consistent with the hypothesis that the Coastal Plain basement rock is an amalgamated Gondwanan island arc.

Thin sections analysis from core samples of well BE-110-2004 show the material is rich in quartz and lithic fragments, with rare plagioclase and potassium feldspar (Poythress R., unpublished). Using ternary diagrams with quartz, feldspar, and lithic fragments as apices (Figure 28), NA phanerozoic sandstones may be classified into three main classes of tectonic setting. These settings are magmatic arcs, continental blocks, and recycled orogens. Results suggest the recovered Triassic strata have a provenance of recycled orogenic material (Poythress R., unpublished).

Comparison of whole rock samples from well BE-110-2004 to Bhatia and Crook's (1986) geochemical tectonic facies do not conclusively correspond with a tectonic province, but some general trends in ratios are observed (Figure 29 and 30). The geochemical analysis shows characteristics of trace element ratios resembling both continental island arc and active continental margins tectonic settings (Poythress R., unpublished). One interpretation of these data is that the sediments in the concealed basin have undergone multiple orogenies and denudation events eliminating any conclusive geochemical signatures of the Triassic strata within the basin.

A magnetic susceptibility survey was conducted for the Hope Plantation core beginning with Cretaceous sediments at $880 \mathrm{ft}$ and continuing to a depth of approximately 1,000 ft (Figure 32). Values generally trend towards higher magnetic susceptibility. This rate is roughly $.43 \mathrm{cgs} / \mathrm{ft}$ with increasing core depth (Poythress R., unpublished). At depths greater than approximately $1,000 \mathrm{ft}$, values trend toward lower magnetic susceptibility. The sediments classified as Triassic 
in age tend to have lower magnetic susceptibility than the overlying Cretaceous sediments. An abundance of quartz observed in thin section analysis could be one explanation for the decreasing susceptibility values. As the abundance of quartz increases, the relative abundance of paramagnetic and ferrimagnetic minerals decreases.

Stratigraphically, the Triassic basin's assumed position within the rift margin and relatively small size likely resulted in the basin's quick infilling, and later associations of the Newark Supergroup, such as lacustrine environments, may never have been developed. This suggests most stratigraphic layers will be alluvial or fluvial with periodic cycling, and lacustrine and marginal associations may be absent due to filled accommodation space. Slightly metamorphosed siltstones and sandstones should be the most common Triassic basin infill with limited, if any, lacustrine deposits. Cores from the Hope Plantation support this, although limited to approximately $100 \mathrm{ft}$ of the topmost unit, with redbed siltstones and sandstones with interspersed conglomerates (Weems et al., 2007).

A two-stage gravity survey was conducted in Bertie County, NC, to constrain the dimensions, geometry, density, and structural variation of the rift feature. More than 200 gravity stations were measured over an area of roughly 1000 square kilometers in central and southwest Bertie County and western Martin County, North Carolina. These stations were then combined with readings from the PACES database to construct a complete Bouguer anomaly contour map which highlights the basins boundaries. Modeling of the gravity data shows a maximum gravity anomaly of approximately $7 \mathrm{mGal}$ for the Bertie basin. Modeling of the data suggests the basin is elongate, generally SW to NE, and is approximately $15 \mathrm{~km}$ wide, $50 \mathrm{~km}$ long, and as much as 2.5 $\mathrm{km}$ deep. In cross section, the basin is asymmetrical and wedge-shaped, with a NW margin that dips steeply SE and a SE margin that dips more shallowly NW. 
The western margin of the basin is bounded by a ridge oriented parallel to the basin and on trend, with a ridgeline from which a crystalline monadnock protrudes out of the Coastal Plain sediments in Fountain. NC. It is likely this ridge represents the uplifted footwall of the main bounding fault of the basin. The eastern margin is also bounded by a ridge but has a smaller gravity anomaly of approximately $5 \mathrm{mGal}$ and seems broken or discontinuous further to the south. The Bouguer anomaly in this area becomes more negative and smoothly transitions southeasterly into the adjacent negative anomaly. The breaks in the eastern ridge could represent hydrogeologic openings that allowed water to pass thru the basin. Alternatively, the larger gravitational anomaly along the ridge may be gravitational expression of whatever units/faults are creating the elongate magnetic lineaments, as they are superimposed along the ridgeline.

The northern termination point of the basin is in north-central Bertie County where both marginal ridges generally converge. Well BT-T-1-73 reached basement rock near this area at an altitude of -988 ft with no indication of Triassic strata. The southern termination point is in southcentral Martin County, does not have converging margins, and is the deepest part of the basin. This also supports the idea of a hydrogeologically open basin in which water flowed southward and emptied into a deeper basin.

East and south of the eastern margin is a negative gravity anomaly of approximately 20 mGal. This area coincides with north/south magnetic lineaments that may be explained by a duplex system along a fault plain separating lithologic belts, a syncline/anticline style of deformation, domino-style faulting that occurred during the main rifting event, or mafic igneous intrusions of unknown, but constrained, density and depth. It remains unclear if this bordering anomaly is associated with rifting and/or caused by some other process. If this anomaly is part of a series of 
basins resulting from sequential faulting, the larger magnitude suggests that it may be larger and deeper than the Bertie basin

Inverse modeling of the gravity data allowed construction of several cross sections. Two transects, $\mathrm{AA}^{\prime}$ and $\mathrm{BB}^{\prime}$, generally run east to west across different halves of the basin (Figure $\mathrm{X}$ and X). A third transect, CC', runs north to south on trend with the northern and southern termination points (Figure X). Nonunique solutions for gravity surveys and the absence of deep coring in the area make it difficult to determine the depth and density of the units bounding the basin or the bands of high and low magnetic susceptibility adjacent to the basin. The lack of known parameters limits the accuracy and precision of the model resulting in higher degrees of uncertainty and error. Forward modeling was used to constrain ranges of values for different parameters, such as the density and depth of units, to limit uncertainty in inverse models. Densities of $1.9 \mathrm{~g} / \mathrm{cm}^{3}$, $2.35 \mathrm{~g} / \mathrm{cm}^{3}$, and $2.67 \mathrm{~g} / \mathrm{cm}^{3}$ were assumed for the Coastal Plain sedimentary strata, Triassic sedimentary units, and crystalline basement rock, respectively.

Cross-section A to A', oriented generally east to west, spans across the northern extent of the Bertie basin and adjacent gravitational anomaly to the east. The regional anomaly, -0.142624 $\mathrm{mGal} / \mathrm{km}$, caused by the dipping basement surface and thickening Coastal Plain cover was modeled and corrected for based on Lawrence and Hoffman's (1993) interpretative geologic map of basement rock depth and dip. Despite this correction, the modeled cross-sections show an increase in depth of the basement rock eastward suggesting that the Bertie basin might be a subbasin, a half-graben within a larger rift basin, or part of a series of basins from domino-style faulting. This configuration gives an error of 0.182 between measured and calculated anomalies with a modeled maximum depth of approximately $1 \mathrm{~km}$ in the vicinity of the Hope Plantation. A 
significant anomaly also exists near the center of the basin that might be explained by half-graben geometry or displacement along fault blocks.

Cross-section $\mathrm{B}$ to $\mathrm{B}^{\prime}$ is oriented generally east-west across the southern extent of the Bertie basin and adjacent gravitational anomaly to the east. The regional anomaly, -0.13724 $\mathrm{mGal} / \mathrm{km}$, was calculated and corrected for in the same manner as in transect AA'. The same densities and parameters were also used for this transect. This configuration gives an error of 0.192 between measured and calculated anomalies and a maximum depth of $2.0 \mathrm{~km}$ for the basin. A similar anomaly also exists near the center of the basin, as in transect AA', supporting the possibility of half-graben formation. Similar gravity anomalies between transects also align east of the basin within the adjacent negative $20 \mathrm{mGal}$ anomaly suggesting a series of north-south striking fault blocks produced by domino-style faulting that may be the underlying cause of the anomaly.

Cross-section C to C' is oriented northeast-southwest, generally through the center of the Bertie basin. Because this transect is oriented along strike to the dipping basement, a very small regional anomaly of $-0.02781 \mathrm{mGal} / \mathrm{km}$ was calculated and corrected for. The same densities and parameters as in transect $\mathrm{AA}^{\prime}$ were used for this transect. This configuration gives an error of 0.258 between measured and calculated anomalies and a maximum depth of approximately $2.5 \mathrm{~km}$ for the modeled basin. The Bertie basin deepens to the south in a step-like manner with several corresponding anomalies in the models subsurface. It is possible the anomalous signatures are caused by the same feature as in the other transects, but with transect CC' aligned so that it crosses back and forth repeatedly.

Even with the regional anomalies corrected for, the modeled basin depths are on the large side of what would be expected for a basin of its length and width. One possible mechanism that 
may cause larger gravitational signatures is a density difference between crustal blocks to the east and west of the main bounding fault. Two wells that reached basement rock in Bertie County demonstrate that rock suites vary on either side of the basin bounding fault, although density values remain unknown, a small difference between density of crustal blocks can cause a significant gravitational anomaly regionally. Further supporting this idea is that the basin is on trend with a linear feature to the south that separates high and low relief magnetic anomalies identified by Lawrence and Hoffman (1993) and interpreted as a possible unnamed fault underneath Coastal Plain sediment

Regional anomaly data shows a negative Bouguer anomaly adjacent to the Bertie basin that stretches from the North Carolina/Virginia state line in the north to Beaufort and Pitt Counties in the south. In this region, evidence of diabase sheets and dikes exist and may be partially responsible for the large gravity anomaly in the area, although no age dating has been performed on any recovered samples of diabase. If a larger basin is present, the narrow bands of high magnetic susceptibility could be reinterpreted as mafic dikes or north/south striking fault ridges of basement rock. Magnetic susceptibility analysis from the Hope Plantation core shows the Triassic units have a low magnetic susceptibility and may contribute to the magnetic anomaly through deepening and shallowing of Triassic strata in conjunction with faulting. Another possible interpretation of these magnetic lineaments is that a major fault system may be separating slate belts or terranes. That interpretation supports the idea that Triassic basins often form along fault systems that may be reactivated Paleozoic structures.

The Bertie basin has low economic potential for both mineralization and hydrocarbon production. The main limiting factors are the absence of igneous intrusions and the low probability that lacustrine environments developed before complete infilling occurred. Both 
factors decrease the likelihood of significant economic potential, although fracking of shale units could possibly produce enough gas for local usages if significant lacustrine deposition did occur. Migration of brines within the basins, unrelated to igneous activity, could cause mineralization and be associated with sediment-hosted, stratabound and vein-type mineral deposits. Sandstonehosted deposits, associated with organic debris, are Cu-rich and are often emriched in Ag and occasionally U. Also possible are base metals, barite veins, and replacement deposits associated with faults, fractures, or shear zones which are locally enriched in $\mathrm{Pb}, \mathrm{Zn}, \mathrm{Cu}, \mathrm{Ag}$, barite, and fluorite (Robinson and Sear, 1992). Depth to the basin and constraints due to size would make recovery of any potential deposits too expensive for economic use.

Large scale features such as the North American rift margin are important in piecing together the complex nature and processes involved with the breaking apart of supercontinents. Recognition of characteristics and spatial distribution between basins underneath the Coastal Plain, even on a smaller scale such as the Bertie basin, will play a significant role in future exploration for other buried basins and potential petroleum resources along the rift margin. Understanding rift basin formation, geometries, and basin-fill stratigraphy also provides insight to subjects like supercontinent breakup, large scale rifting processes, crustal thinning, and mantle flow. 


\section{Chapter 12: Conclusions}

(1) The Bertie basin is a relatively small Triassic rift basin located in Bertie County, North Carolina, approximately $1,000 \mathrm{ft}$ beneath the Coastal Plain sedimentary cover.

(2) The basin's geometry and orientation reflect regional trends and characteristics of other Southern rift basins with type B and BB geometries. Type B basins are narrow half-graben basins with limited or no growth structures.

(3) The basin is elongate, generally SW to NE, and is approximately $15 \mathrm{~km}$ wide, $50 \mathrm{~km}$ long, and as much as $2.5 \mathrm{~km}$ deep.

(4) It is asymmetrical and wedge-shaped, with a steeply dipping NW margin and a more shallowly dipping SE margin.

(5) The buried basin creates a maximum gravity anomaly of approximately $7 \mathrm{mGal}$ with an adjacent $20 \mathrm{mGal}$ anomaly to the east coinciding with north/south oriented magnetic lineaments representing bands of mafic and sedimentary, seaward dipping, metavolcanic units that may have developed from sequential faulting during rifting.

(6) If this interpretation is correct, then the Bertie basin may be one in a series of basins or a sub-basin within a larger basin.

(7) The Bertie basin was likely hydrogeologically open to the south where the basin is deepest and breaks appear along the hanging wall's ridgeline.

(8) The basin has limited economic potential due to size and burial. 


\section{References}

Anderson, D.L., 1982. Hotspots, polar wander, Mesozoic convection and the geoid. Nature, 297, 391-393.

Anderson, D.L., 1994. Superplumes or supercontinents?. Geology 22, 39-42.

Bain, G.L. and Harvey, B.W. (Editors), 1977. Field guide to the Geology of the Durham Triassic Basin. Carolina Geol. Soc., Raleigh, N.C., 83 pp.

Bally, A.W., 1981. Atlantic-type margins, in Geology of Passive Continental Margins, Education Course Notes Set. 19, edited by A. W. Bally, pp. I1-I48, American Association of Petroleum Geologists, Tulsa, Oklahoma.

Barton, P., and Wood, R., 1984. Tectonic evolution of the North Sea Basin: Crustal stretching and subsidence, Geophys. J. R. Astron. Soc., 79, 987-1022.

Behrendt, J.C., and Klitgord, K.D., 1979. Basin Structure of the US Atlantic Margin: Rifted Margins. Pp.85-112

Benson, R.N., 1984. Structure contour map of pre-Mesozoic basement, landward margin of Baltimore Canyon trough: Delaware Geologic Survey Miscellaneous Map Series No. 2, map scale 1:500,000, 1 sheet.

Bhatia, M. R., and Crook, K. A. W., 1986. Trace element characteristics of graywackes and tectonic setting discrimination of sedimentary basins, Contrib. Mineral. Petrol., 92, 181- 193.

Blake, D.E., Rhodes, D.L., Bradley, P.J., 2012. Ductile-brittle fabric development in Carolina terrane rocks along the northwestern boundary of the Durham sub-basin, Deep River Triassic rift basin, North Carolina.

Blakey, Ron. http://jan.ucc.nau.edu/rcb7/nat.html. Maps: Tectonics, Sedimentation, Paleogeography of North Atlantic Region.

Bonini, W.E., and Woodard, G.P., 1960. Subsurface geology of North Carolina-South Carolina Coastal Plain from seismic data: American Association of Petroleum Geologists Bulletin, v. 44, p. 298-315.

Bosworth, W., 1987. Off-axis volcanism in the Gregory rift, east Africa: Implications for models of continental rifting, Geology, 15, 397-400.

Brown, P.M., Miller, J.A., Swain, F.M., 1972. Structural and stratigraphic framework, and spatial distribution of permeability of the Atlantic Coastal Plain, North Carolina to New York: U.S. Geological Survey Professional Paper 796, 79 p. 
Brune, S., Heine, C., Perez-Gussinye, M., Sobolev, S., 2014. Rift migration explains continental margin asymmetry and crustal hyper-extension. Nature Communications: 5:4014 DOI:

10.1038/ncomms5014.

Brune, S., Heine, C., Clift, P., Perez-Gussinye, M., 2017. Rifted margin architecture and crustal rheology: Reviewing Iberia-Newfoundland, Central South Atlantic, and South China Sea. Marine and Petroleum Geology 79, 257-281. dx.doi.org/10.1016/j.merpetgeo.2016.10.01802648172

Burke, K.C.A., and Dewey, J.F., 1973. Plume generated triple junctions: Journal of Geology, v. 86, p. 406-433.

Butler, J.R., 1991. Metamorphism, in Horton, J.W., Jr., and Zullo, V.A., editors, The geology of the Carolinas, Carolina Geological Society $50^{\text {th }}$ Anniversary Volume: Knoxville, University of Tennessee Press, p. 127-141.

Callegaro, S., Marzoli, A., Bertrand, H., Chiaradia, M., Reisberg, L., Meyzen, C., Bellieni, G., Weems, R.E., Merle, R., 2013. Upper and lower crust recycling in the source of CAMP basaltic dykes from southeastern North America. Earth Planet. Sci. Lett. 376, 186-199.

Campbell, M.R. and Kimball, K.W., 1923. The Deep River Coal Field of North Carolina: North Carolina Geological and Economic Survey Bulletin 33, 95p., prepared by the USGS in cooperation with the North Carolina Geological and Economic Survey.

Chabou, M.C., Bertrand, H., Sebaï, A., 2010. Geochemistry of the Central Atlantic Magmatic Province (CAMP) in south-west Algeria. J. Afr. Earth Sci. 58, 211-219.

Chapman, M.J.; Cravotta III, C.A.; Szabo, Z.; Lindsay, B.D., 2013. Naturally Occurring Contaminants in the Piedmont and Blue Ridge Crystalline-Rock Aquifers and Piedmont Early Mesozoic Basin Siliciclastic-Rock Aquifers, Eastern United States, 1994-2008; US Geological Survey Scientific Investigations Report 2013-5072; U.S. Geological Survey: Reston, VA, USA.

Chowns, T.M., and Williams, C.T., 1983. Pre-Cretaceous rocks beneath the Georgia Coastal Plain- regional implications, in Gohn, G.S., ed., Studies related to the Charleston, South Carolina earthquake of 1886- Tectonics and Seismicity: U.S. Geological Survey Professional Paper 1313 p. L1-L42.

Condie, K.C., 2016. Earth as an Evolving Planetary System. $3^{\text {rd }}$ Edition.

Cook, F.A., and Oliver, J.E., 1981. The late Precambrian-early Paleozoic continental edge in the Appalachian orogen. Am. J. Sci., 281, 993-1008.

Cook, F.A., Brown, L.D., Kaufman, S., Oliver, J.E., and Petersen, T.A., 1981. COCORP seismic profiling of the Appalachian orogen beneath the Coastal Plain of Georgia, Part I: Geological Society of America Bulletin, v. 92, p. 738-748. 
Cornet, B. and Olsen, P.E., 1985. A summary of the biostratigraphy of the Newark Supergroup of Eastern North America with comments on early Mesozoic provinciality. Extended Abstract of III Congreso Latinoamericano de Paleontologia, Mexico; Simposio Sobre Floras Des Triasico Tardio, Su Fitogeografia y Paleoecologia, Memoria, pp. 67-81.

Courtillot, V., and Renne, P.R., 2003. On the ages of flood basalt events. C.R. Geosci. 335, 113140.

Cowie, P.A., and Scholz, C.H., 1990. Fault growth and fault termination. EOS, Trans. Am.geophys. Un. 71,631.

Crespi, J.M., 1988. Using balanced cross sections to understand early Mesozoic extensional faulting. In A. J. Froelich and G. R. Robinson Jr., eds., Studies of the Early Mesozoic Basins of the Eastern United States, pp. 220-229. U.S. Geological Survey Bulletin, no. 1776. Washington, D.C.: Government Printing Office.

Cserepes, K., and Christensen, J., 1990. Three-dimensional convection under drifting plates: Geophysical Research Letters, v. 17, p. 1497-1500.

Dal Corso, J., Marzoli, A., Tateo, F., Jenkyns, H.C., Bertrand, H., Youbi, N., Mahmoudi, A., Font, E., Buratti, N., Cirilli, S., 2014. The dawn of CAMP volcanism and its bearing on the endTriassic carbon cycle disruption. J. Geol. Soc. Lond. 171, 153-164.

Dallmeyer, R.D., 1989. Contrasting accreted terranes in the southern Appalachian orogen and Atlantic-GulfCoastal Plains and their correlations with west African sequences, in Dallmeyer, R. D., editor, Terranes in the circum-Atlantic Paleozoic orogens: Geological Society of America Special Paper 230, p. 247-267.

Daniels, D.L., and Leo, G.W., 1985. Geologic interpretation of basement rocks of the Atlantic Coastal Plain: U.S. Geological Survey Open-File Report 85-655, 45 p.

Daniels, D.L., and Zietz, I., 1978. Geologic interpretation of aeromagnetic maps of the Coastal Plain region of South Carolina and parts of North Carolina and Georgia: U.S. Geological Survey Open- File Report 78-261, 47 p.

Davies, G.F., and Richards, M.A., 1992. Mantle convection: Journal of Geology, v. 100, p. 151206.

Denison, R.E., Raveling, H.P., and Rouse, J.T., 1967. Age and descriptions of subsurface basement rocks, Pamlico and Albemarle Sound areas, North Carolina: American Association of Petroleum Geologists Bulletin, v. 51, p. 268-272.

Dickinson, W.R., Beard, L.S., Brakenridge, G.C., Erjavec, J.L., Ferguson, R.C., Inman, K.F., Knepp, R.A., Lindberg, F.A., Ryberg, P.T., 1983. Provenance of North American Phanerozoic sandstones in relation to tectonic setting. GSA Bulletin 94(2): 222-235. https://doi.org/10.1130/0016-7606(1983)94<222:PONAPS>2.0.CO;2 
Dow, W.G., and O'Connor, D.I., 1982. Kerogen maturity and type by reflected light microscopy applied to petroleum exploration, in Staplin, F. L., and other, How to Assess Maturation and Paleotemperatures: Society of Economic Paleontologists and Mineralogists, Short Course Number 7, p. 133-158 ([sic] - last page blank and unnumbered).

Emmons, E., 1852. Report of Professor Emmons on his geological survey of North Carolina, Raleigh, N.C., Seaton Gales, 181 p.

Emmons, W.H., and Garrey, G. H., 1910. General geology. In: Geology and Ore Deposits of the Bullfrog district (Ed. by F. L. Ransome et al.). Bull. US gcol.. Surv., 407, 19-89.

Forsyth, D.W., and Uyeda, S., 1975. On the relative importance of the driving forces of plate motion: Royal Astronomical Society Geophysical Journal, v. 43, p. 163-200.

Froelich, A.J., and Olsen, P.E., 1984. Newark Supergroup, a revision of the Newark Group in Eastern North America: U.S. Geological Survey Bulletin 1537-A, p. 55-58.

Gibbs, A.D., 1983. Balanced cross-section construction from seismic sections in areas of extensional tectonics: Journal of Structural Geology, v. 5, p. 153-160.

Gibson, J.R., Walsh, J.J., Watterson, J., 1989. Modelling of bed contours and cross-sections adjacent to planar normal faults. J. Struct. Geol. 11, 317-328.

Gore, P.J.W., 1989. Toward a model for open- and closed- basin deposition in ancient lacustrine sequences: the Newark Supergroup (Triassic-Jurassic), eastern North America. Palaeogeogr., Palasoclimatol., Palaeoecol., 70: 29-51.

GRAV-D Team (2014). "Block ES04 (Eastern South 04); GRAV-D Airborne Gravity Data User Manual." Monica Youngman and Carly Weil, ed. Version BETA. Available DATE. Online at: http://www.ngs.noaa.gov/GRAV-D/data_ES04.shtml

Griffiths, R.W., and Campbell, I.H., 1990. Stirring and structure in mantle plumes: Earth and Planetary Science Letters, v. 99, p. 66-78.

Grow, J.A., 1981. Structure of the Atlantic Margin of the United States, in Geology of Passive Continental Margins, pp. 3-1-3-41, ed. Bally, A.W., Amer. Assoc. Pet. Geol., Tulsa, Oklahoma.

Guo, W., Zhao, S., Wang, F., Yang, Z., Jia, S., Liu, Z., 2019. Crustal Structure of the eastern Piedmont and Atlantic coastal plain in North Carolina and Virginia, eastern North American margin. Earth Planets Space 71, 69. https://doi.org/10.1186/s40626-019-1049-z

Gurnis, M., and Zhong, S., 1991. Generation of long wavelength heterogeneity in the mantle by the dynamic interaction between plates and convection: Geophysical Research Letters, v. 18, p. 581-584. 
Hammer, S., 1939. Terrain corrections for gravimeter stations. Geophysics, 4, pp.184- 194.

Hibbard, J.P., Stoddard, E.F., Secor, D.T., and Dennis, A.J., 2002. The Carolina Zone: Overview of Neoproterozoic to Early Paleozoic peri-Gondwanan terranes along the eastern flank of the southern Appalachians: Earth-Science Reviews, v. 57, p. 299-339. doi:10.1016/S00128252(01)00079-4

Hill, R.I., 1991. Starting plumes and continental break-up. Earth Planet. Sci. Lett. 104, 398-416.

Hill, R.I., Campbell, I.H., Davies, G.F., Griffiths, R.W., 1992a. Mantle plumes and continental tectonics. Science, 256: 186-193

Hinz, K., 1981. A hypothesis on terrestrial catastrophies. Wedges of very thick oceanward dipping layers beneath passive continental margins. Their origin and paleoenvironmental significance. Geologisches Jahrbuch. Reihe E, Geophysik, (22), pp.3-28.

Hoffman, C.W. and Gallagher, P.E., 1988. Geology of the Southeast and Southwest Durham 7.5minute quadrangles, North Carolina. NC Geol. Surv. Bull, 92, p.34.

Horton, J.W., Drake, A.A., Rankin, D.W., Dallmeyer, R.D., 1991. Preliminary tectonostratigraphic terrane map of the central and southern Appalachians: U.S. Geological Survey Map 1-2163, map scale 1:2,000,000, 1 sheet, descriptive text, 15 p.

Horton, J.W., Drake, A.A., Rankin, D.W., 1989. Tectonostratigraphic terranes and their Paleozoic boundaries in the central and southern Appalachians: in Dallmeyer, R.D., editor, Terranes in the circum-Atlantic Paleozoic orogens: Geological Society of America Special Paper 230, p. 213-245.

Huismans, R.S., Beaumont, C., 2014. Rifted continental margins: the case for depth dependent extension. Earth Planet. Sci. Lett. 407, 148-162.

Hutchinson, D.R., and Klitgord, K.D., 1985. Deep structure of rift basins from the continental margin around New England. In A. J. Froelich and G. R. Robinson Jr., eds., Studies of the Early Mesozoic Basins of the Eastern United States, pp. 211-219. U.S. Geological Survey Bulletin, no. 1776. Washington, D.C.: Government Printing Office.

Hutchinson, D.R., Klitgord, K.D., Schouten, H., 1988. US Atlantic continental margin; structural and tectonic framework. The Geology of North America, 2, pp.19-55.

Hutchinson, D.R., Grow, J.A., Klitgord, K.D., 1983. Crustal structure beneath the southern Appalachians: Non-uniqueness of gravity modeling: Geology, v. 11, p. 611-615.

Hutchinson, D.R., Grow, J.A., Klitgord, K.D., Swift, B.A., 1982. Deep structure and evolution of the Carolina trough, in Watkins, J.S., and Drake, C.L., eds., Studies in continental margin geology: American Association of Petroleum Geologists Memoir 34, p. 129-152. 
Hutchinson, D.R., Klitgord, K.D., Derrick, R.S., 1986. Rift basins of the Long Island platform, Geol. Soc. Am. Bull., 97, 688-702.

Hutchinson, D.R., Poag, C.W., Popenoe, P., 1996. Geophysical database of the East Coast, of the United States: southern Atlantic Margin stratigraphy and velocity from multichannel seismic profiles, US Geol. Survey Open File Report, 95-27, 65.

Iverson, W.P., and Smithson, S.B., 1983. Reprocessing and reinterpretation of COCORP southern Appalachian profiles. Earth and Planetary Sci. Lett., 62, 75-90

Karner, G.D. and Watts, A.B., 1982. On isostasy at Atlantic-type continental margins, J. geophys. Res., 87, 2923-2948.

Keen, C.E., Keen, M.J., Barrett, D.L., Heffier, D.E., 1975. Some aspects of the ocean-continent transition at the continental margin of eastern North America, Offshore Geology of Eastern Canada, 2, Regional Geology, Geol. Surv. Pap. Geol. Surv. Can., 74-30, 189-197.

Kent, D.V., Olsen, P.E., 2000. Magnetic polarity stratigraphy and paleolatitude of the Triassic Jurassic Blomidon Formation in the Fundy Basin (Canada): implications for early Mesozoic tropical climate gradients. Earth Planet. Sci. Lett. 179, 311-324.

Kent, D.V., Tauxe, L., 2005. Corrected Late Triassic latitudes for continents adjacent to the North Atlantic. Science 307, 240-244.

Klitgord, K.D., and Behrendt, J.C., 1979. Basin structure of the U.S. Atlantic margin, Geological and Geophysical Investigations of Continental Margins, edited by J. S. Watkins, L. Montadert, and P. A. Dickerson, Mere. Am. Assoc. Pet. Geol., 29, 85-112.

Klitgord, K.D., and Hutchinson, D.R., 1985. Distribution and geophysical signatures of early Mesozoic rift basins beneath the U.S. Atlantic coastal margin, in Robinson, G.R., Jr., and Froelich, A.J., eds., Proceeding of the second U.S. Geological Survey workshop on the early Mesozoic basins of the Eastern United States: U.S. Geological Survey Circular 946, p. 45-61.

Klitgord, K.D., Hutchinson, D.R., Schouten, H., 1988. U.S. Atlantic continental margin; structural and tectonic framework. In: Sheridan, R.E., Grow, J.A. (Eds.), The Atlantic Continental Margin; U.S. I-2. The Geology of North America, pp. 19-55.

Krohn, M.D., Evans, J., Robinson, G.R., Jr., 1988. Mineral-bound ammonium in black shales of the Triassic Cumnock Formation, Deep River basin, North Carolina., in Robinson, G.R., Jr., and Froelich, A.J., eds., Proceedings of the second U.S. Geological Survey workshop on the early Mesozoic basins of the Eastern United States: U.S. Geological Survey Circular 946, p. 86-98.

LaFehr, T.R., 1991. Standardization in gravity reduction. Geophysics, 56(8), pp.1170-1178.

Lai, S.F., Ferguson, J.F., Aiken, C.L.V., Ziegler, D., 1985. A test of gravity and magnetic anomaly inversion in defining the structure of the Sanford Basin, North Carolina, as an example 
of a Triassic basin (in Society of Exploration Geophysicists, 55th annual meeting, Anonymous) SEG Abstracts (1985), (1): 207-210.

Lambiase, J.J., 1990. A model for tectonic control of lacustrine stratigraphic sequences in continental rift basins. In: Katz, B.J. (Ed.), Lacustrine Basin Exploration: Case Studies and Modern Analogs 50. Am. Association Petr. Geol. Mem., pp. 265-276.

Labails, C., Olivet, J-L., Aslanian, D., Roest, W.R., 2010. An alternative early opening scenario for the Central Atlantic Ocean. Earth and Planetary Sci. Lett., 297, 355-368.

LASE Study Group, 1986. Deep structure of the US East Coast passive margin from large aperture seismic experiments (LASE), Mar. Petrol. Geol., 3, 234-242.

Lawrence, D.P., and Hoffman, C.W., 1993. Geology of basement rocks beneath the North Carolina coastal plain: North Carolina Geological Survey Bulletin 95.

Leleu, S., Hartley, A., Oosterhout, C., Kennan, L., Ruckwied, K., Gerdes, K., 2016. Structural, stratigraphic and sedimentological characterization of a wide rift system: The Triassic rift system of the Central Atlantic Domain. Earth Sci. Rev. 158, pp. 89-124.

Lister, G.S., Etheridge, M.A., Symonds, P.A., 1986. Detachment faulting and the evolution of passive continental margins, Geology, 14, 246-250.

Longwell, C.R., 1943. Geologic interpretation of gravity anomalies in the southern New England-Hudson Valley region: Geological Society of America Bulletin, v. 54, p. 555-590.

Lorenz, J.C., 1988. Triassic-Jurassic Rift Basin Sedimentology. Van Nostrand Rheinhold, New York, N.Y., 315 pp.

Manspeizer, W., 1981. Early Mesozoic basins of the central Atlantic passive margins, in Bally, A.W., ed., Geology of passive continental margins: History, structure, and sedimentologic record (with special emphasis on the Atlantic margin): American Association of Petroleum Geologists Education Course Note Series No. 19, p. 4-1 to 4-60.

Manspeizer, W., 1985. Early Mesozoic history of the Atlantic passive margin, in Geologic Evolution of the United States Atlantic Margin, edited by C. W. Poag, pp. 1-23, Van Nostrand Reinhold, New York, N.Y..

Manspeizer, W., Cousminer, H.L., 1988. Late Triassic-Early Jurassic synrift basins of the U.S. Atlantic margin. In: Sheridan, R.E., Grow, J.A. (Eds.), The Atlantic Continental Margin; U.S. The Geology of North America I-2, pp. 197-216.

Martins, L.T., Madeira, J., Youbi, N., Munhá, J., Mata, J., Kerrich, R., 2008. Rift-related magmatism of the Central Atlantic magmatic province in Algarve, Southern Portugal. Lithos $101,102-124$. 
Mauger, R.L., Spruill, R.K., Lawrence, D.P., and Moncla, A.M., 1987. Geology and petrology of the Fountain and Rocky Mount quarries, easternmost Piedmont, North Carolina, in Whittecar, G.R., editor, Geological excursions in Virginia and North Carolina, Guidebook for Field Trips: Geological Society of America Southeastern Section meeting, Norfolk, Virginia, p. 219-228.

McHone, J.G., 2000. Non-plume magmatism and rifting during the opening of the central Atlantic Ocean. Tectonophysics 316, 287-296.

McHone, J.G., 2003. Volatile emissions from Central Atlantic Magmatic Province basalts: mass assumptions and environmental consequences. In The Central Atlantic Magmatic Province: Insights from fragments of Pangea, AGU 241-254.

McKenzie, D.P., 1978. Some remarks on the development of sedimentary basins, Earth Planet. Sci. Lett., 40, 25-32.

McKenzie, D.P., 1985. The extraction of magma from the crust and mantle, Earth Planet. Sci. Lett., 74, 81-91.

McKenzie, D.P., and Bickle, M.J., 1988. The volume and composition of melt generated by extension of the lithosphere, J. Petrol., 29, 625-679.

Michael, H.A., 2013. An arsenic forecast for China. Science, 341, 852-853.

Milici, R.C., 1995. The Blue Ridge thrust belt (068), Piedmont Province (069), Atlantic Coastal Plain Province (070), Adirondack Province (071) and New England Province (072), in Gautier, D. L., Dolton, G. L., Takahashi, K. I., and Varnes, K. L., 1995 National Assessment of United States oil and gas resources-results, methodology, and supporting data: U.S. Geological Survey Digital Data Series DDS-30.

Milici, R.C., Coleman, J.L., Rowan, E.L., Cook, T.A., Charpentier, R.R., Kirschbaum, M.A., Klett, T.R., Pollastro, R.M. and Schenk, C., 2012. Assessment of undiscovered oil and gas resources of the East Coast Mesozoic basins of the Piedmont, Blue Ridge thrust belt, Atlantic Coastal Plain, and New England provinces, 2011. Fact Sheet, 3075.

Moulin, M., Aslanian, D., Oliver, J.L., Construcci, I., Matias, L., Géli, L., Klingelhoefer, F., Nouzé, H., Réhault, J.-P., Unternher, P., 2005. Geological constraints on the evolution of the Angolan margin based on reflection and refraction seismic data (ZaïAngo project). Geophys. J. Int. $162,793-810$.

Mutter, J.C., 1985. Seaward dipping reflectors and the continent-ocean boundary at passive continental margins: Proceedings of the 1983 IUGG Conference, Tectonophysics, 114, 117-131.

Mutter, J.C., Buck, S.R., Zehnder, C.M., 1988. Convective partial melting, 1. A model for the formation of thick basaltic sequences during the initiation of spreading: Journal of Geophysical Research, v. 93, p. 1031-1048. 
Nataf, H.C., Froidevaux, C., Levrat, J.L., and Rabinowicz, M., 1981. Laboratory convection experiments: Journal of Geophysical Research, v. 86, p. 6143-6154.

Nelson, K.D., Arnow, J.A., McBride, J.H., Willemin, J.H., Huang, J., Zheng, L., Oliver, J.E., Brown, L.D., Kaufman, S., 1985a. New COCORP profiling in the southeastern United States, 1, Late Paleozoic suture and Mesozoic rift basin, Geology, 13,714-717.

Nelson, K.D., McBride, J.H., Arnow, J.A., Oliver, J.E., Brown, L.D., Kaufman, S., 1985b. New COCORP profiling in the southeastern United States, II, Brunswick and east coast magnetic anomalies, opening of the north-central Atlantic Ocean, Geology, 13(10), 718-721.

Olsen, P.E., 1980. The latest Triassic and Early Jurassic formations of the Newark basin (eastern North America, Newark Supergroup): Stratigraphy, structure, and correlation: New Jersey Academy of Science Bulletin, v. 25, p. 25-51.

Olsen, P.E., 1986. A 40-million-year lake record of early Mesozoic orbital climate forcing. Science, v. 234, p. $842-848$.

Olsen, P.E., 1990. Tectonic, climatic, and biotic modulation of lacustrine ecosystems: examples from Newark Supergroup of eastern North America. Lacustrine basin exploration; case studies and modern analogs. Am. Association Petr. Geol. Mem. 50, 209-224.

Olsen, P.E. and Kent, D.V., 1996. Milankovitch climate forcing in the tropics of Pangaea during the Late Triassic. Palaeogeography, Palaeoclimatology, Palaeoecology, 122(1-4), pp.1-26.

Olsen, P.E. and Schlische, R.W., 1988. Quantitative rift basin evolution: Application of extensional basin filling model to early Mesozoic rifts, E. North America. Geol. Soc. Am. Abstr. With Program, 20, p. A123

Olsen, P.E., McCune, A.R., and Thomson, K.S., 1982. Correlation of the early Mesozoic Newark Supergroup by vertebrates, principally fishes: American Journal of Science, v. 282, p. 1-44.

Olsen, P.E., Schlische, R.W., Gore, P.J.W., 1989. Newark Basin, Pennsylvania and New Jersey; stratigraphy. Field Trips for the 28th International Geological Congress. Am. Geophys. Union, Washington, DC, pp. 69-152.

Olsen, P.E., Froelich, A.J., Daniels, D.L., Smoot, J.P., and Gore, P.J.W., 1991. Rift basins of early Mesozoic age, in Horton, J.W., and Zullo, V.A., eds., The Geology of the Carolinas: Knoxville, Tennessee, University of Tennessee Press, p. 142-170.

Olsen, P.E., Kent, D.V., Cornet, B., Witte, W.K., Schlische, R.W., 1996. High-resolution stratigraphy of the Newark rift basin (early Mesozoic, eastern North America). Geol. Soc. Am. Bull. 108, 40-77. 
Olsen, P.E., Reid, J.C., Taylor, K.B., Whiteside, J.H., Kent, D.V., 2015. Revised Stratigraphy of Late Triassic Age Strata of the Dan River Basin (Virginia and North Carolina, USA) Based on Drill Core and Outcrop Data. Southeast. Geol. 51, 1-31.

PACES database. Pan-American Center for Earth and Environmental Studies. University of Texas, El Paso. http://research.utep.edu/default.aspx?tabid=37229

Peron-Pinvidic, G., Manatschal, G., 2010. From microcontinents to extensional allochthons: witnesses of how continents break apart? Petroleum Geoscience 16, 189-197.

Peron-Pinvidic, G., Manatschal, G., Osmundsen, P.T., 2013. Structural comparison of archetypal Atlantic rifted margins: A review of observations and concepts. Marine and Petroleum Geology. Issue 43, pp. 21-47

Poythress, R. \& Horsman, E., 2013. Abstract: Preliminary findings of a recently discovered Mesozoic rift basin concealed beneath Coastal Plain cover, Bertie County, North Carolina

Pratt, L.M., Vuletich, A.K., Daws, T.A., 1985. Geochemical and isotopic characterization of organic matter in rocks of the Newark Supergroup. In: G.R. Robinson Jr. and A.J. Froelich (Editors), Proc. $2^{\text {nd }}$ U.S. Geol. Surv. Workshop Early Mesozoic Basins of the Eastern United States. U.S. Geol. Surv. Circ., 946: 74-78.

Ratcliffe, N.M., Burton, W.C., D'angelo, R.M. and Costair, J.K., 1986. Low-angle extensional faulting, reactivated mylonites, and seismic reflection geometry of the Newark basin margin in eastern Pennsylvania. Geology, 14(9), pp.766-770.

Reid, J.C., and Milici, R.C., 2008, Hydrocarbon source rocks in the Deep River and Dan River Triassic Basins, North Carolina: U.S. Geological Survey Open-File Report 2008-1108, 28p.

Reinemund, J.A., 1955. Geology of the Deep River coal field, North Carolina: U.S. Geological Survey Professional Paper 246,159 p.

Richards, H.G., 1954. Subsurface Triassic in eastern North Carolina. AAPG Bulletin, 38(12), pp.2564-2565.

Richter, F.M., and McKenzie, D., 1981. Parameterizations for the horizontally averaged temperature of infinite Prandtl numbers convection, J. Geophys. Res., 86, 1738-1744.

Robbins, E.I., and Textoris, D.A., 1986. in Gore, Pamela, J. W., editor, Depositional Framework of a Triassic Rift basin: The Durham and Sanford Sub-basins of the Deep River basin, North Carolina, Field Trip \#3, September 24-25, 1986, The Society of Economic Paleontologists and Mineralogists, Third Annual Midyear Meeting, Raleigh, North Carolina, p. 75-79.

Robbins, E.I., Wilkes, G.P., Textoris, D.A., 1988. Coal deposits of the Newark rift system. In: W. Manspeizer (Editor), Triassic-Jurassic Rifting: North America and North Africa. Elsevier, Amsterdam, pp. 649-682. 
Robinson, G.R., Jr., 1985. Ore deposit models and mineral resource studies in the early Mesozoic basins of the Eastern United States, in Robinson, G.R., Jr., and Froelich, A.J., eds., Proceedings of the second U.S. Geological Survey workshop on the early Mesozoic basins of the Eastern United States: U.S. Geological Survey Circular 946, p. 117-120.

Robinson, G.R., Jr., Sears, C.M., 1992. Inventory of metal mines and occurrences associated with the early Mesozoic basins of the Eastern United States - Summary Tables, in Robinson, G.R., Jr., and Froelich, A.J., eds., Proceedings of the second U.S. Geological Survey workshop on the early Mesozoic basins of the Eastern United States: U.S. Geological Survey Circular 946, p. 265-302.

Ruiz-Martínez, V.C., Torsvik, T.H., Van Hinsbergen, D.J.J., Gaina, C., 2012. Earth at 200 Ma: Global paleogeography refined from CAMP palaeomagnetic data. Earth Planet. Sci. Lett. 331$332,67-79$.

Russell, G.S., Russell, C.W., Farrar, S.S., 1985. Alleghanian deformation and metamorphism in the eastern North Carolina Piedmont: Geological Society of America Bulletin, v. 96, p. 381-387.

Sahabi, M., Aslanian, D., Olivet, J.L., 2004. Un nouveau point de départ pour l'histoire de l'Atlantique central. C. R. Géoscience 336, 1041-1052.

Sampair, J.L., 1979. Geological and geophysical evaluation of the Graingers basin for Triassic sediment: North Carolina Geological Survey Open-File Report 79-1, 9 p.

Schlee, J.S., 1981. Seismic stratigraphy of Baltimore Canyon Trough, Am. Assoc. Pet. Geol. Bull., 65, 26-53.

Schlische, R.W., 1990b. Aspects of the structural and stratigraphic development of early Mesozoic rift basins of eastern North America. PhD thesis, Columbia University, 579 p.

Schlische, R.W., 1991. Half-graben basin filling models: new constraints on continental extensional basin development. Basin Research, 3, 123-141.

Schlische, R.W., 1993. Anatomy and evolution of the Triassic-Jurassic continental rift system, eastern North America. Tectonics 12, 1026-1042.

Schlische, R.W., and Olsen, P.E., 1990. Quantitative filling models for continental extensional basins with applications to the early Mesozoic rifts of eastern North America. J. Geol. 98, 135155.

Schlische, R.W., Withjack, M.O., Olsen, P.E., 2002. Rift-basin structure and its influence on sedimentary systems.

Schlische, R.W., Withjack, M.O., Olsen, P.E., 2003. Relative timing of CAMP, rifting, continental breakup, and basin inversion: tectonic significance. In: Hames, W.E., et al, (Eds.), The Central Atlantic Magmatic Province. American Geophysical Union. 
Schoene, B., Guex, J., Bartolini, A., Schaltegger, U., Blackburn, T.J., 2010. Correlating the endTriassic mass extinction and flood basalt volcanism at the $100 \mathrm{ka}$ level. Geology 38, 387-390.

Secor, D.T., Jr., Snoke, A.W., and Dallmeyer, R.D., 1986. Character of the Alleghenian orogeny in the southern Appalachians, Part III, Regional tectonic relations: Geological Society of America Bulletin, v. 97, p. 1345-1353.

Secor, D.T., Murray, D.P., Glover, L., Ill, 1990. Geology of Avalonian rocks, in Rankin, D.W., Drake, A.A., Jr., Glover, L., Ill, Goldsmith, R., Hall, L.M., Murray, D.P., Ratcliffe, N.M., Read, J.F., Secor, D.T. , Jr., and Stanley, R.S., editors, Pre-orogenic terranes, in Hatcher, R.D., Jr., Thomas, W.A., and Viele, G.W., editors, The Appalachian-Ouachita Orogen in the United States: The Geology of North America, v. F-2: Geological Society of America, p. 57-100.

Serfes, M.E., Herman, G.C., Spayd, S.E., Reinfelder, J., 2010. Sources, mobilization and transport of arsenic in groundwater in the Passaic and Lockatong formations of the Newark Basin, New Jersey. In Contributions to the Geology and Hydrogeology of the Newark Basin; New Jersey Geological Survey Bulletin 77; New Jersey Geological Survey: Ewing Township, NJ, USA, 2010; Chapter E.

Smedley, P.L., and Kinniburgh, D.G., 2002. A review of the source, behaviour and distribution of arsenic in natural waters. Appl. Geochem. 2002, 17, 517-568.

Smoot, J.P., 1985. The closed basin hypothesis and its use in facies analysis of the Newark Supergroup. In: G.R. Robinson Jr. and A.J. Froelich (Editors), Proc. $2^{\text {nd }}$ U.S. Geol. Surv. Workshop Early Mesozoic Basins of the Eastern United States. U.S. Geol. Surv. Circ., 946: 7478.

Smoot, J.P., 1991. Sedimentary facies and depositional environments of early Mesozoic Newark Supergroup basins, eastern North America. Paleogeogr. Paleoclimatol. Paleoecol. 84, pp. 369423

Smoot, J.P., LeTourneau, P.M., Turner-Peterson, C.E., Olsen, P.E., 1985. Sandstone and conglomerate shoreline deposits in the Triassic-Jurassic Newark and Hartford basins of the Newark Supergroup (abs.): American Association of Petroleum Geologists Bulletin, v. 69, p. 1448.

Stollenwerk, K.G., 2003. Spectrographic investigations of arsenic species in solid phases, in Welch, A.H., and Stollenwerk, K.G., eds.: Arsenic in Groundwater, Geochemistry and Occurrence, Kluwer Academic Publishers, Boston, chapter 3, p. 67-100.

Sutter, J. F., 1988. Innovative approaches to dating of igneous events in the Early Mesozoic basins, U.S. Geol. Surv. Bull., 1776, 194-200.

Thayer, P.A., 1987, Petrology, diagenesis, and petrophysical characteristics of Upper Triassic Dan River Group sandstones, NC and VA [abstract]: Society of Economic Paleontologists and Mineralogists, Abstracts, v. 4, p. 83-84. 
Thayer, P.A., 1970. Stratigraphy and geology of Dan River Triassic basin, North Carolina: Southeastern Geology, v. 12, p. 1-31.

Tissot, B.P., and Welte, D.H., 1978. Petroleum formation and occurrence, second revised and enlarged edition: Springer-Verlag, New York, 699p.

Thomas, W.A., Chowns, T.M., Daniels, D.L., Neathery, T.L., Glover, L., Ill, and Gleason, R.J., 1989. The subsurface Appalachians beneath the Atlantic and Gulf Coastal Plains: in Hatcher, R.D., Jr., Thomas, W.A., and Viele, G.W., editors, The Appalachian- Ouachita Orogen in the United States: The Geology of North America, v. F-2: Geological Society of America, p. 445458.

Trehu, A.M., Ballard, A., Dorman, L.M., Gettrust, J.F., Klitgord, K.D., Schreiner, A., 1989. Structure of the Lower Crust Beneath the Carolina Trough, U.S. Atlantic Continental Margin. J. Geophys. Res., v. 94, no. B8, pp. 10585-10600.

USGS, 2012. Assessment of Undiscovered Oil and Gas Resources of the East Coast Mesozoic Basins of the Piedmont, Blue Ridge Thrust Belt, Atlantic Coastal Plain, and New England Provinces. Fact Sheet 2012-3075, June 2012.

VanDerwerker, T., Zhang, L., Ling, E., Benham, B., Schreiber, M., 2018. Evaluating Geologic Sources of Arsenic in Well Water in Virginia (USA), Int. J. Environ. Res. Public Health, 15, 787; doi: 10.3390/ijerph15040787.

Van Houten, F.B., 1962. Cyclic sedimentation and the origin of analcime-rich upper Triassic Lockatong Formation, west central New Jersey and adjacent Pennsylvania: American Journal of Science, v. 260, p. 561-576.

Van Houten, F.B., 1964. Cyclic lacustrine sedimentation, Upper Triassic Lockatong Formation, central New Jersey and adjacent Pennsylvania: Geological Survey of Kansas Bulletin, no. 169, p. 497-531.

Verosub, K. L., and Roberts, A. P., 1995. Environmental magnetism: Past, present, and future. Journal of Geophysical Research, 100 (B2), 2175-2192. https://doi.org/10.1029/94JB02713

Vervoort, J.D., Wirth, K., Kennedy, B., Sandland, T., Harpp, K.S., 2007. The magmatic evolution of the Midcontinent rift: New geochronological and geochemical evidence from felsic magmatism. Precambrian Res., 157 (1-4), pp. 235-268.

Watkins, J.S., Best, D.M., Murphy, C.N., and Geddes, W.H., 1985. An investigation of the Albermarle Sound gravity anomaly, northeastern North Carolina, southeastern Virginia, and adjacent continental shelf: Southeastern Geology, v. 26, p. 67-80.

Watterson, J., 1986. Fault dimensions, displacements, and growth. Pure Appl. Geophys. 124, 365-373. 
Weems, R.E., Seefelt, E.L., Wrege, B.M., Self-Trail, J.M., Prowell, D.C., Durand, C., Cobbs III, E.F., Mckinney, K.C., 2007. Preliminary physical stratigraphy and geophysical data of the USGS Hope Plantation Core (BE-110), Bertie County, North Carolina. U.S. Geological Survey Openfile report 2007-1251.

Welch, A.H., Westjohn, D.B., Helsel, D.R., Wanty, R.B., 2000. Arsenic in ground water of the United States: Occurrence and geochemistry. Ground Water 2000, 38, 589-604.

Wernicke, B., 1985. Uniform-sense normal simple shear of the continental lithosphere, Can. J. Earth Sci., 22, 108-125, 1985.

Wernicke, B., and Burchfiel, B.C., 1987. Modes of extensional tectonics, J. Struct. Geol., 4, 105$115,1982$.

White, R.S., 1988b. The Earth's crust and lithosphere, Oceanic and continental lithosphere: Similarities and differences, J. Petrol. Special Lithosphere Issue, 1-10, 1988 b.

White, R.S., and McKenzie, D.P., 1989. Magmatism at rift zones: the generation of volcanic continental margins and flood basalts. J. Geophys. Res., 94, pp.7685-7730.

White, R.S., Spence, G.D., Fowler, S.R., McKenzie, D.P., Westbrook, G.K., Bowen, A.N., 1987b. Magmatism at rifted continental margins, Nature, 330, 439-444.

Whiteside, J.H., Olsen, P.E., Eglinton, T., Brookfield, M.E., Sambrotto, R.N., 2010. Compoundspecific carbon isotopes from Earth's largest flood basalt eruptions directly linked to the endTriassic mass extinction. Proceedings North American Society 107, 6721-6725.

Williams, H., and Hatcher, R.D., 1982. Suspect terrenes and accretionary history of the Appalachian orogen: Geology, v. 10, p. 530-536.

Wilson, M., 1997. Thermal evolution of the Central Atlantic passive margins: continental breakup above a Mesozoic superplume. J. Geol. Soc. Lond. 154, pp. 491-495.

Withjack, M.O., Schlische, R.W., 2005. A review of tectonic events on the passive margin of eastern north America. Special Publications, Gulf Coast Section SEPM Foundation, ISSN: 15442462.

Withjack, M.O., Olsen, P.E., Schlische, R.W., 1998. Diachronous rifting, drifting, and inversion on the passive margin of central eastern North America: an analog for other passive margins. Am. Association Petr. Geol. Bull. 82, pp. 817-835.

Withjack, M.O., Schlische, R.W., and Olsen, P.E., 2012, Development of the passive margin of eastern North America: Mesozoic rifting, igneous activity, and breakup, in Roberts, D.G., and Bally, A.W., eds., Phanerozoic Rift Systems and Sedimentary Basins: Amsterdam, Netherlands, Elsevier, p. 301-335, doi:10.1016/B978-0-444-56356-9.00012-2. 
Wyers, P., and Watts, A.B., 2006. Gravity anomalies and segmentation at the East Coast, USA continental margin. Geophys. J. Int., 166, 1015-1038. doi: 10.1111/j.1365-246X.2006.03066.x Ziegler, P.A., 1983. Crustal thinning and subsidence in the North Sea, Nature, 304, p.561. www.auburn.edu/academic/science_math/res_area/geology/camp/MapsFigures

www.earth.google.com

www.geology.com 


\section{Appendix A: Lithofacies and Depositional Environment}

Table 1A: Lithofacies description and interpretation of North American Triassic basins (from Smoot, 1991, modified) and re-interpretation in term of main paleo-environments (Leleu et al., 2016)

\begin{tabular}{|c|c|c|c|c|}
\hline $\begin{array}{l}\text { North } \\
\text { American } \\
\text { basins } \\
\text { facies }\end{array}$ & $\begin{array}{l}\text { Brief description (From } \\
\text { Smoot, 1991, modified) }\end{array}$ & $\begin{array}{l}\text { Interpretation } \\
\text { (Smoot, 1991) }\end{array}$ & $\begin{array}{l}\text { More details and } \\
\text { interpretations } \\
\text { (Leleu et al., } \\
\text { 2016) }\end{array}$ & $\begin{array}{l}\text { Main depositional } \\
\text { environments } \\
\text { (Leleu et al., 2016) }\end{array}$ \\
\hline (AF1) & $\begin{array}{l}\text { Matrix-supported } \\
\text { conglomerates poorly } \\
\text { sorted, comprising } \\
\text { boulders, and forming } \\
\text { lenses } \\
\text { convex-upwards }\end{array}$ & $\begin{array}{l}\text { Debris flow } \\
\text { deposits }\end{array}$ & debris flow & Alluvial-fan deposits \\
\hline (AF2) & $\begin{array}{l}\text { Clast-supported } \\
\text { conglomerates forming } \\
\text { lenses locally convex- } \\
\text { upwards, and } \\
\text { interbedded } \\
\text { with sandstone beds }\end{array}$ & $\begin{array}{l}\text { Deposited by flash- } \\
\text { flooding shallow- } \\
\text { braided streams }\end{array}$ & $\begin{array}{l}\text { Debris flow or } \\
\text { hyperconcentrated } \\
\text { flow }\end{array}$ & \\
\hline (AF3) & $\begin{array}{l}\text { Conglomerates } \\
\text { presenting cross-bedding } \\
\text { and imbrications }\end{array}$ & $\begin{array}{l}\text { Formed by braided } \\
\text { stream processes } \\
\text { on fans }\end{array}$ & $\begin{array}{l}\text { Stream flow } \\
\text { processes }\end{array}$ & \\
\hline (AF4) & $\begin{array}{l}\text { Pebbly muddy } \\
\text { sandstones forming } \\
\text { isolated channel-form } \\
\text { lenses and comprising } \\
\text { imbricated } \\
\text { cobble, cross-beds and } \\
\text { horizontal stratification }\end{array}$ & $\begin{array}{l}\text { Deposits of } \\
\text { hyperconcentrated } \\
\text { sheetfloods or } \\
\text { braided stream } \\
\text { deposits }\end{array}$ & $\begin{array}{l}\text { Stream flow } \\
\text { processes }\end{array}$ & \\
\hline (F1) & $\begin{array}{l}\text { Imbricate boulder and } \\
\text { cobble conglomerate, } \\
\text { poorly sorted pebbly } \\
\text { sandstone and } \\
\text { sandstones } \\
\text { presenting crude } \\
\text { upwards-fining } \\
\text { sequences }(0.3-2.0 \mathrm{~m} \\
\text { thick). Sandstones are } \\
\text { dominated by } \\
\text { planar horizontal or low- } \\
\text { angle lamination }\end{array}$ & $\begin{array}{l}\text { Braided stream } \\
\text { deposits }\end{array}$ & & Coarse fluvial deposits \\
\hline (F2) & $\begin{array}{l}\text { Poorly sorted cross- } \\
\text { bedded pebbly } \\
\text { sandstones overlying } \\
\text { cobble and boulder } \\
\text { conglomerate } \\
\text { and presenting fining- } \\
\text { upwards sequences (2.0- } \\
6.0 \text { m thick), abruptly } \\
\text { overlain by heavily }\end{array}$ & $\begin{array}{l}\text { It is interpreted to } \\
\text { be deposited by } \\
\text { braided streams, } \\
\text { locally } \\
\text { anastomosing on } \\
\text { vegetated } \\
\text { muddy plains }\end{array}$ & $\begin{array}{l}\text { It seems that F1 } \\
\text { and F2 are lateral } \\
\text { equivalents of a } \\
\text { similar system }\end{array}$ & \\
\hline
\end{tabular}




\begin{tabular}{|c|c|c|c|c|}
\hline & $\begin{array}{l}\text { bioturbated mudstone or } \\
\text { siltstone. }\end{array}$ & & & \\
\hline (F3) & $\begin{array}{l}\text { (F3) is similar to (F2) but } \\
\text { conglomerates are } \\
\text { moderately sorted }\end{array}$ & Braided stream & $\begin{array}{l}\text { F1, F2, F3 were } \\
\text { deposited by the } \\
\text { same } \\
\text { fluvial system }\end{array}$ & \\
\hline (F4) & $\begin{array}{l}\text { Sandstone, siltstone, and } \\
\text { mudstone forming } \\
\text { rhythmically stacked, } \\
\text { upwards fining- } \\
\text { sequences } \\
\text { (2-7 m thick). } \\
\text { Sandstones comprise } \\
\text { trough cross-beds at the } \\
\text { base grading to rippled } \\
\text { cross-laminated fine } \\
\text { sandstone capped by } \\
\text { heavily bioturbated } \\
\text { zones. Stacked sequences } \\
\text { occur as a depositionally } \\
\text { inclined lense that is } \\
\text { thicker and coarser } \\
\text { downdip }\end{array}$ & $\begin{array}{l}\text { This facies is } \\
\text { interpreted as } \\
\text { lateral accretion } \\
\text { on point bars and } \\
\text { therefore as a } \\
\text { meandering fluvial } \\
\text { system }\end{array}$ & & Sandy fluvial deposits \\
\hline (F5) & $\begin{array}{l}\text { (F5) is similar to (F4) but } \\
\text { contains mud lenses and } \\
\text { coarse scour at the base } \\
\text { of sandstones. }\end{array}$ & $\begin{array}{l}\text { Meandering fluvial } \\
\text { system }\end{array}$ & $\begin{array}{l}\text { (F4) and (F5) } \\
\text { should be grouped } \\
\text { in a single facies }\end{array}$ & \\
\hline$(\mathrm{F} 6)$ & $\begin{array}{l}\text { Mudstone, siltstone and } \\
\text { fine-grained sandstone } \\
\text { with abundant root } \\
\text { structures, burrows, and } \\
\text { local carbonate nodules }\end{array}$ & $\begin{array}{l}\text { Interpreted as } \\
\text { fluvial flood plain } \\
\text { where soil } \\
\text { development } \\
\text { occurred }\end{array}$ & & Floodplain deposits \\
\hline (F7) & $\begin{array}{l}\text { Poorly sorted } \\
\text { conglomerate with } \\
\text { angular clasts forming } \\
\text { imbrications and cross- } \\
\text { beds in } \\
\text { places. }\end{array}$ & $\begin{array}{l}\text { This is interpreted } \\
\text { as colluvium } \\
\text { deposited within } \\
\text { bedrock } \\
\text { topography }\end{array}$ & $\begin{array}{l}\text { Alluvial fan } \\
\text { deposits }\end{array}$ & Colluvium deposits \\
\hline (L1) & $\begin{array}{l}\text { Finely laminated, } \\
\text { organic-rich shale and } \\
\text { limestone alternating } \\
\text { with siltstone beds. } \\
\text { Burrows are locally } \\
\text { abundant, fossil-fish well } \\
\text { preserved and aquatic } \\
\text { reptile and } \\
\text { conchostracans and } \\
\text { ostracods abundant. }\end{array}$ & $\begin{array}{l}\text { This facies is } \\
\text { interpreted to be } \\
\text { deposited in deep } \\
\text { perennial lakes }\end{array}$ & & $\begin{array}{l}\text { Perennial lake } \\
\text { deposits }\end{array}$ \\
\hline (L2) & $\begin{array}{l}\text { Thin-bedded to massive } \\
\text { mudstone, commonly } \\
\text { organic-rich with } \\
\text { abundant burrows, } \\
\text { alternating with graded } \\
\text { sandstones presenting }\end{array}$ & $\begin{array}{l}\text { This facies is } \\
\text { interpreted to be } \\
\text { deposited in } \\
\text { shallow perennial } \\
\text { lake, or margin of } \\
\text { deeper lake }\end{array}$ & & \\
\hline
\end{tabular}




\begin{tabular}{|c|c|c|c|c|}
\hline & $\begin{array}{l}\text { soft-sedimentation } \\
\text { deformation. Ostracods, } \\
\text { conchostracans and } \\
\text { wood fragment are } \\
\text { common. Polygonal } \\
\text { cracks and root structure } \\
\text { occur occasional. }\end{array}$ & $\begin{array}{l}\text { with occasional } \\
\text { subaerial exposure }\end{array}$ & & \\
\hline (L3) & $\begin{array}{l}\text { Thin-bedded mudstone } \\
\text { and siltstone with } \\
\text { abundant polygonal } \\
\text { cracks. Siltstone and } \\
\text { occasional sandstone } \\
\text { beds present abundant } \\
\text { scours and intraclasts. }\end{array}$ & $\begin{array}{l}\text { This facies was } \\
\text { deposited in } \\
\text { shallow ephemeral } \\
\text { lake or fluctuating } \\
\text { margin of larger } \\
\text { lake }\end{array}$ & & $\begin{array}{l}\text { Ephemeral lake } \\
\text { deposits }\end{array}$ \\
\hline (L4) & $\begin{array}{l}\text { Massive mudstone with } \\
\text { abundant, sinuous } \\
\text { polygonal cracks. } \\
\text { Breccia-like fabric of } \\
\text { mudstone separated by } \\
\text { silt-rich cracks. Fillings } \\
\text { gradationally overlie L2 } \\
\text { or L3 deposits. }\end{array}$ & $\begin{array}{l}\text { This facies } \\
\text { represents a } \\
\text { period of playa dry } \\
\text { mud-flat showing } \\
\text { alteration of wet } \\
\text { and dry periods }\end{array}$ & & \\
\hline (L5) & $\begin{array}{l}\text { Poorly sorted, sandy } \\
\text { mudstone with irregular } \\
\text { pods of siltstone and } \\
\text { sandstone and irregular } \\
\text { sandstone beds with } \\
\text { hump-shape ripples and } \\
\text { deformed boundaries. }\end{array}$ & $\begin{array}{l}\text { This facies } \\
\text { represents salt- } \\
\text { encrusted saline } \\
\text { mudflat }\end{array}$ & & Saline mudflat \\
\hline (L6) & $\begin{array}{l}\text { Massive mudstone and } \\
\text { siltstone with abundant } \\
\text { cement- or sediment- } \\
\text { filled root structures, } \\
\text { carbonate nodules, } \\
\text { remnant patches of } \\
\text { rippled sandstone, and } \\
\text { polygonal cracks. }\end{array}$ & $\begin{array}{l}\text { This facies } \\
\text { represents } \\
\text { vegetated mudflat }\end{array}$ & & $\begin{array}{l}\text { Mudflat lateral to } \\
\text { playa lakes or } \\
\text { floodplain with } \\
\text { crevasse splay } \\
\text { deposits }\end{array}$ \\
\hline (LM1) & $\begin{array}{l}\text { Channel-form sandstone } \\
\text { or conglomerate lenses } \\
\text { (10 to several 10's } \\
\text { meters wide and 2-10 m } \\
\text { thick) intercalated with } \\
\text { (L1) or (L2) facies. } \\
\text { Sandstone lenses present } \\
\text { trough cross-bedding } \\
\text { and grade upwards to } \\
\text { ripple cross-lamination } \\
\text { with soft-deformation } \\
\text { structures. Bioturbation } \\
\text { may disrupt the top of } \\
\text { sequences. }\end{array}$ & $\begin{array}{l}\text { This facies } \\
\text { represents delta } \\
\text { deposits when lake } \\
\text { level drops }\end{array}$ & $\begin{array}{l}\text { Fluvial channel } \\
\text { deposits eroding } \\
\text { the } \\
\text { playa during a lake } \\
\text { level fall }\end{array}$ & $\begin{array}{l}\text { Distal fluvial channel } \\
\text { deposits of a terminal } \\
\text { splay, eroding playa } \\
\text { during a lake level fall }\end{array}$ \\
\hline (LM2) & $\begin{array}{l}\text { Depositionally inclined } \\
\text { sandstone sets stacked to }\end{array}$ & $\begin{array}{l}\text { This facies has } \\
\text { been interpreted }\end{array}$ & $\begin{array}{l}\text { Fluvial terminal } \\
\text { splay deposits on } \\
\text { the playa margin }\end{array}$ & $\begin{array}{l}\text { Terminal splay } \\
\text { deposits or fan delta }\end{array}$ \\
\hline
\end{tabular}




\begin{tabular}{|c|c|c|c|c|}
\hline & $\begin{array}{l}\text { form upward coarsening } \\
\text { sequences }(10-40 \\
\mathrm{m} \text { thick). The low-angle } \\
\text { sets in the lower portion } \\
\text { of the sequence are } \\
\text { dominated by climbing } \\
\text { ripples. }\end{array}$ & $\begin{array}{l}\text { as deposits of } \\
\text { Gilbert-type delta }\end{array}$ & $\begin{array}{l}\text { or fan delta } \\
\text { deposits if water } \\
\text { level is relatively } \\
\text { high }\end{array}$ & $\begin{array}{l}\text { deposits depending } \\
\text { on lacustrine level } \\
\text { (depending on } \\
\text { associated lacustrine } \\
\text { facies) }\end{array}$ \\
\hline (LM3) & $\begin{array}{l}\text { Wedge-shape sandstone } \\
\text { sheets comprising } \\
\text { sandstone thin beds of } \\
\text { climbing ripples } \\
\text { intercalated by clay } \\
\text { partings with polygonal } \\
\text { cracks. }\end{array}$ & $\begin{array}{l}\text { This facies } \\
\text { represent sheet- } \\
\text { like deltaic plain } \\
\text { deposits produced } \\
\text { by the intersection } \\
\text { of very } \\
\text { shallow lake with } \\
\text { flash-flooding } \\
\text { streams. }\end{array}$ & $\begin{array}{l}\text { This facies is } \\
\text { equivalent to } \\
\text { terminal } \\
\text { splay }\end{array}$ & $\begin{array}{l}\text { Distal terminal splay } \\
\text { deposits }\end{array}$ \\
\hline (LM4) & $\begin{array}{l}\text { Graded sandstones to } \\
\text { conglomerates forming } \\
\text { coarsening-upward } \\
\text { sequences (3-10 m } \\
\text { thick) } \\
\text { from (L1) or (L2) } \\
\text { deposits. Lower } \\
\text { sequence dominated by } \\
\text { oscillatory ripple cross- } \\
\text { lamination grading up to } \\
\text { flat-bedded pebbly } \\
\text { sandstones. Upper } \\
\text { sequence is poorly } \\
\text { sorted boulder to cobble } \\
\text { conglomerates } \\
\text { comprising patchy } \\
\text { rippled-sandstones. }\end{array}$ & $\begin{array}{l}\text { This facies is } \\
\text { interpreted as } \\
\text { wave sorted } \\
\text { shoreline deposits }\end{array}$ & $\begin{array}{l}\text { Alluvial-fan } \\
\text { deposits on the } \\
\text { margin of the lake }\end{array}$ & Fan-delta deposits. \\
\hline (LM5) & $\begin{array}{l}\text { Similar facies to LM4 but } \\
\text { conglomerates absent. }\end{array}$ & $\begin{array}{l}\text { It is interpreted to } \\
\text { be a distal } \\
\text { equivalent to } \\
\text { (LM4) }\end{array}$ & $\begin{array}{l}\text { Alluvial-fan } \\
\text { deposits on the } \\
\text { margin of the lake }\end{array}$ & \\
\hline
\end{tabular}




\section{Appendix B: Metal Mines and Occurrences in North Carolina}

Table 1B: Inventory of metal mines and occurrences associated with early Mesozoic basins of the Eastern United States (Robinson and Sears, 1992, modified)

\begin{tabular}{|c|c|c|c|c|c|c|c|c|}
\hline \multirow{2}{*}{$\begin{array}{l}\text { Locality } \\
\text { Number }\end{array}$} & \multirow[t]{2}{*}{ Name } & \multirow[t]{2}{*}{ Latitude } & \multirow[t]{2}{*}{ Longitude } & \multirow{2}{*}{$\begin{array}{l}\text { Locality } \\
\text { Type }\end{array}$} & \multirow[t]{2}{*}{ Deposit Type } & \multirow{2}{*}{$\begin{array}{l}\text { Host-rock } \\
\text { Lithology }\end{array}$} & \multicolumn{2}{|c|}{ Metal Associations } \\
\hline & & & & & & & Principal & Accessory \\
\hline \multicolumn{9}{|c|}{ Davie County basin, North Carolina -- Area 8} \\
\hline 270 & $\begin{array}{l}\text { Bell } \\
\text { Branch } \\
\text { gold }\end{array}$ & $\mathrm{N} 36^{\circ} 02^{\prime} 38^{\prime \prime}$ & W80³9'10" & Occurrence & Placer & Gravel & $\mathrm{Au}$ & - \\
\hline \multicolumn{9}{|c|}{ Deep River basin and vicinity, North Carolina - Area 9} \\
\hline 271 & $\begin{array}{l}\text { Whomble } \\
\text { prospect }\end{array}$ & $\mathrm{N} 35^{\circ} 38^{\prime} 18^{\prime \prime}$ & W7907'17”' & Prospect & Placer & Gravel & $\mathrm{Au}$ & - \\
\hline 272 & $\begin{array}{l}\text { Clegg } \\
\text { copper } \\
\text { mine }\end{array}$ & $\mathrm{N} 35^{\circ} 35^{\prime} 20^{\prime \prime}$ & W7908'17” & Mine & Vein & Metavolcanic & $\mathrm{Cu}$ & - \\
\hline 273 & $\begin{array}{l}\text { Tennessee } \\
\text { copper }\end{array}$ & $\mathrm{N} 35^{\circ} 30^{\prime} 08^{\prime \prime}$ & $\mathrm{W} 79^{\circ} 25^{\prime} 06^{\prime \prime}$ & Prospect & $\begin{array}{l}\text { Vein- } \\
\text { replacement }\end{array}$ & Metavolcanic & $\mathrm{Cu}$ & - \\
\hline 274 & $\begin{array}{l}\text { Harrisville } \\
\text { barite }\end{array}$ & $\mathrm{N} 35^{\circ} 12^{\prime} 42^{\prime \prime}$ & W79 $48^{\circ} 57^{\prime \prime}$ & Occurrence & Vein & Diabase & $\mathrm{Ba}$ & - \\
\hline 275 & $\begin{array}{l}\text { Mangum } \\
\text { gold } 2\end{array}$ & $\mathrm{~N} 35^{\circ} 07^{\prime} 25^{\prime \prime}$ & W7958'30” & Occurrence & Placer & Sandstone & $\mathrm{Au}$ & - \\
\hline 276 & $\begin{array}{l}\text { Mangum } \\
\text { gold } 1\end{array}$ & $\mathrm{~N} 35^{\circ} 07^{\prime} 20^{\prime \prime}$ & W7959'50' & Occurrence & Placer & Sandstone & $\mathrm{Au}$ & - \\
\hline
\end{tabular}




\section{Appendix C: Geochemical Data}

Results of whole rock analysis from Acme Labs.

\begin{tabular}{|c|c|c|c|c|c|c|c|c|c|c|c|c|c|c|c|c|c|c|c|c|c|}
\hline \multicolumn{15}{|c|}{ CERTIFICATE OF ANALYSIS } & \multicolumn{7}{|c|}{ VAN13001286.1 } \\
\hline & Method & WGHT & 4A-4B & $4 \mathrm{~A}-4 \mathrm{~B}$ & AA-4B & $4 A-4 B$ & $4 \mathrm{~A}-4 \mathrm{~B}$ & $4 \mathrm{~A}-4 \mathrm{~B}$ & $4 \mathrm{~A}-4 \mathrm{~B}$ & $4 A-4 B$ & $4 A-4 B$ & $4 \mathrm{~A}-4 \mathrm{~B}$ & $4 \mathrm{~A}-4 \mathrm{~B}$ & $4 A-4 B$ & 4A-4B & $4 \mathrm{~A}-4 \mathrm{~B}$ & $4 A-4 B$ & $4 A-4 B$ & $4 \mathrm{~A}-4 \mathrm{~B}$ & 4A-4B & $4 \mathrm{~A}-4 \mathrm{~B}$ \\
\hline & Analyte & Wgt & SiO2 & Al2O3 & $\mathrm{Fe} 2 \mathrm{O} 3$ & $\mathrm{MgO}$ & $\mathrm{CaO}$ & $\mathrm{Na} 20$ & к2О & TiO2 & P2O5 & $\mathrm{MnO}$ & $\mathrm{Cr} 2 \mathrm{O} 3$ & $\mathrm{Ni}$ & Sc & LOI & Sum & $\mathrm{Ba}$ & $\mathrm{Be}$ & Co & Cs \\
\hline & Unit & $\mathrm{kg}$ & $\%$ & $\%$ & $\%$ & $\%$ & $\%$ & $\%$ & $\%$ & $\%$ & $\%$ & $\%$ & $\%$ & ppm & ppm & $\%$ & $\%$ & ppm & ppm & ppm & ppm \\
\hline & $\mathrm{MDL}$ & 0.01 & 0.01 & 0.01 & 0.04 & 0.01 & 0.01 & 0.01 & 0.01 & 0.01 & 0.01 & 0.01 & 0.002 & 20 & 1 & -5.1 & 0.01 & 1 & 1 & 0.2 & 0.1 \\
\hline 1054 & Rock & 0.05 & 53.98 & 11.18 & 5.63 & 0.73 & 0.14 & 0.36 & 1.83 & 0.70 & 0.03 & 0.08 & 0.024 & 75 & 11 & 25.2 & 99.83 & 554 & $<1$ & 15.0 & 2.3 \\
\hline 1055.4 & Rock & 0.04 & 50.21 & 11.06 & 5.80 & 0.71 & 0.20 & 0.48 & 1.68 & 0.84 & 0.02 & 0.05 & 0.020 & 49 & 12 & 28.8 & 99.85 & 357 & $<1$ & 12.2 & 2.4 \\
\hline 1070 & Rock & 0.04 & 62.96 & 13.46 & 5.92 & 1.05 & 0.17 & 0.38 & 2.14 & 0.84 & 0.05 & 0.13 & 0.007 & 34 & 13 & 12.7 & 99.78 & 648 & 2 & 18.7 & 4.1 \\
\hline 1073.6 & Rock & 0.04 & 54.72 & 8.88 & 3.96 & 0.80 & 0.23 & 0.67 & 1.58 & 0.54 & 0.06 & 0.05 & 0.026 & 72 & 10 & 27.3 & 29.85 & 322 & 4 & 10.8 & 2.4 \\
\hline 1077.6 & Rock & 0.04 & 58.87 & 10.98 & 4.05 & 0.93 & 0.24 & 0.84 & 1.21 & 0.73 & 0.06 & 0.05 & 0.006 & 23 & 10 & 21.2 & 99.86 & 374 & $<1$ & 13.3 & 3.5 \\
\hline 1090.5 & Rock & 0.04 & 59.98 & 10.34 & 4.60 & 0.82 & 0.22 & 0.74 & 1.95 & 0.59 & 0.06 & 0.08 & 0.011 & 32 & 10 & 20.5 & 99.86 & 349 & $<1$ & 8.8 & 2.8 \\
\hline
\end{tabular}

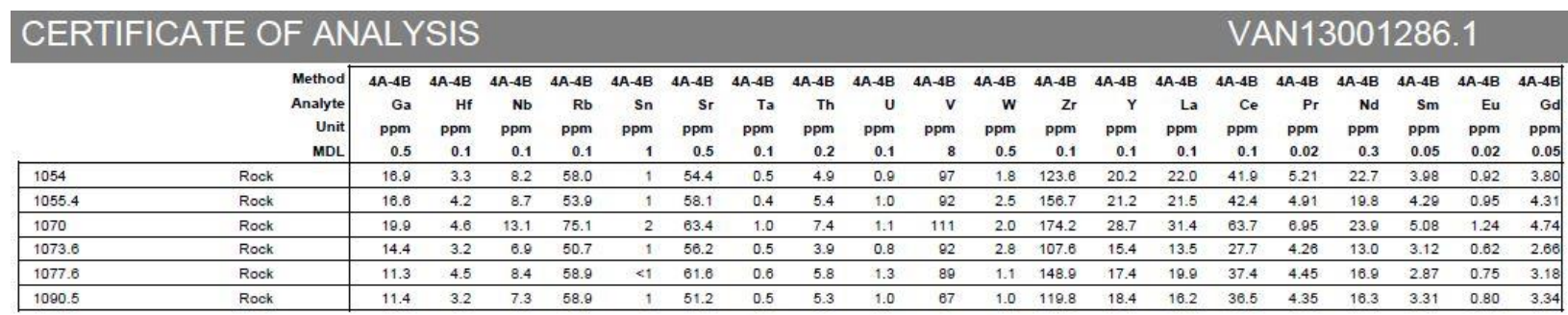

\section{CERTIFICATE OF ANALYSIS $\quad$ VAN13001286.1}

\begin{tabular}{|c|c|c|c|c|c|c|c|c|c|c|c|c|c|c|c|c|c|c|c|c|c|}
\hline & $\begin{array}{r}\text { Method } \\
\text { Analyte } \\
\text { Unit }\end{array}$ & 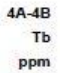 & $\begin{array}{r}4 \mathrm{~A}-4 \mathrm{~B} \\
\mathrm{Dy} \\
\mathrm{ppm}\end{array}$ & $\begin{array}{r}4 \mathrm{~A}-4 \mathrm{~B} \\
\mathrm{Ho} \\
\mathrm{ppm}\end{array}$ & $\begin{array}{r}4 A-4 B \\
E r \\
\text { ppm }\end{array}$ & $\begin{array}{r}4 \mathrm{~A}-4 \mathrm{~B} \\
\mathrm{Tm} \\
\mathrm{ppm}\end{array}$ & $\begin{array}{r}4 \mathrm{~A}-4 \mathrm{~B} \\
\mathrm{Yb} \\
\mathrm{ppm}\end{array}$ & $\begin{array}{c}\text { 4A-4B } 2 \\
\text { Lu } \\
\text { ppm }\end{array}$ & $\begin{array}{r}\text { A Leco } \\
\text { TOT/C } \\
\%\end{array}$ & $\begin{array}{r}\text { 2A Leco } \\
\text { TOT/S } \\
\%\end{array}$ & $\begin{array}{r}10 \mathrm{DX} \\
\mathrm{Mo} \\
\mathrm{ppm}\end{array}$ & $\begin{array}{r}10 \mathrm{DX} \\
\mathrm{Cu} \\
\mathrm{ppm}\end{array}$ & $\begin{array}{r}10 \mathrm{DX} \\
\mathrm{Pb} \\
\mathrm{ppm}\end{array}$ & $\begin{array}{r}10 x \\
Z n \\
\mathrm{ppm}\end{array}$ & $\begin{array}{r}10 \mathrm{X} \\
\mathrm{Ni} \\
\mathrm{ppm}\end{array}$ & $\begin{array}{r}10 \mathrm{X} \\
\text { As } \\
\mathrm{ppm}\end{array}$ & $\begin{array}{r}10 \mathrm{DX} \\
\mathrm{Cd} \\
\mathrm{ppm}\end{array}$ & $\begin{array}{r}10 x \\
\text { Sb } \\
\text { ppm }\end{array}$ & $\begin{array}{r}10 X \\
B i \\
p p m\end{array}$ & $\begin{array}{r}10 \mathrm{X} \\
\mathrm{Ag} \\
\mathrm{ppm}\end{array}$ & $\begin{array}{r}1 \mathrm{Dx} \\
\mathrm{Au} \\
\mathrm{ppb}\end{array}$ \\
\hline & MDL & 0.01 & 0.05 & 0.02 & 0.03 & 0.01 & 0.05 & 0.01 & 0.02 & 0.02 & 0.1 & 0.1 & 0.1 & 1 & 0.1 & 0.5 & 0.1 & 0.1 & 0.1 & 0.1 & 0.5 \\
\hline 1054 & Rock & 0.60 & 4.47 & 0.87 & 2.19 & 0.32 & 2.37 & 1.79 & 16.92 & $<0.02$ & 0.3 & 5.0 & 7.4 & 33 & 14.7 & 5.2 & $<0.1$ & 0.2 & 0.1 & $<0.1$ & $<0.5$ \\
\hline 1055.4 & Rock & 0.68 & 4.08 & 0.88 & 2.56 & 0.36 & 2.75 & 0.40 & 20.21 & $<0.02$ & 0.5 & 4.4 & 11.8 & 32 & 13.8 & 2.0 & $<0.1$ & 0.2 & 0.1 & $<0.1$ & 0.7 \\
\hline 1070 & Rock & 0.83 & 4.83 & 1.08 & 3.21 & 0.45 & 2.51 & 0.40 & 6.51 & $<0.02$ & 0.4 & 7.3 & 9.4 & 42 & 19.3 & 4.8 & $<0.1$ & 0.2 & 0.1 & $<0.1$ & $<0.5$ \\
\hline 1073.6 & Rock & 0.47 & 2.84 & 0.87 & 1.70 & 0.27 & 1.48 & 0.32 & 19.83 & $<0.02$ & 0.4 & 7.5 & 8.2 & 32 & 14.4 & 1.4 & $<0.1$ & 0.1 & $<0.1$ & $<0.1$ & $<0.5$ \\
\hline 1077.6 & Rock & 0.48 & 3.12 & 0.66 & 2.01 & 0.32 & 2.02 & 0.34 & 14.48 & $<0.02$ & 0.4 & 10.1 & 7.8 & 38 & 17.6 & 2.0 & $<0.1$ & 0.1 & 0.1 & $<0.1$ & 0.6 \\
\hline 1090.5 & Rock & 0.54 & 3.31 & 0.71 & 2.13 & 0.31 & 2.23 & 0.31 & 14.12 & $<0.02$ & 0.4 & 6.4 & 8.8 & 32 & 16.7 & 1.4 & $<0.1$ & 0.2 & $<0.1$ & $<0.1$ & $<0.5$ \\
\hline
\end{tabular}

\section{CERTIFICATE OF ANALYSIS}

\section{VAN13001286.1}

\begin{tabular}{|c|c|c|c|c|}
\hline & $\begin{array}{r}\text { Method } \\
\text { Analyte } \\
\text { Unit } \\
\text { MDL }\end{array}$ & $\begin{array}{r}10 \mathrm{X} \\
\mathrm{Hg} \\
\mathrm{ppm} \\
0.01\end{array}$ & $\begin{array}{r}1 \mathrm{DX} \\
\mathrm{TI} \\
\mathrm{ppm} \\
0.1\end{array}$ & $\begin{array}{r}10 x \\
\mathrm{Se} \\
\mathrm{ppm} \\
0.5\end{array}$ \\
\hline 1054 & Rock & $<0.01$ & $<0.1$ & $<0.5$ \\
\hline 1055.4 & Rock & $<0.01$ & $<0.1$ & $<0.5$ \\
\hline 1070 & Rock & $<0.01$ & $<0.1$ & $<0.5$ \\
\hline 1073.8 & Rock & $<0.01$ & $<0.1$ & $<0.5$ \\
\hline 1077.6 & Rock & $<0.01$ & $<0.1$ & $<0.5$ \\
\hline 1090.5 & Rock & $<0.01$ & $<0.1$ & $<0.5$ \\
\hline
\end{tabular}




\section{Appendix D: Forward Modeling}

Forward modeling was done in Oasis:Montaj:

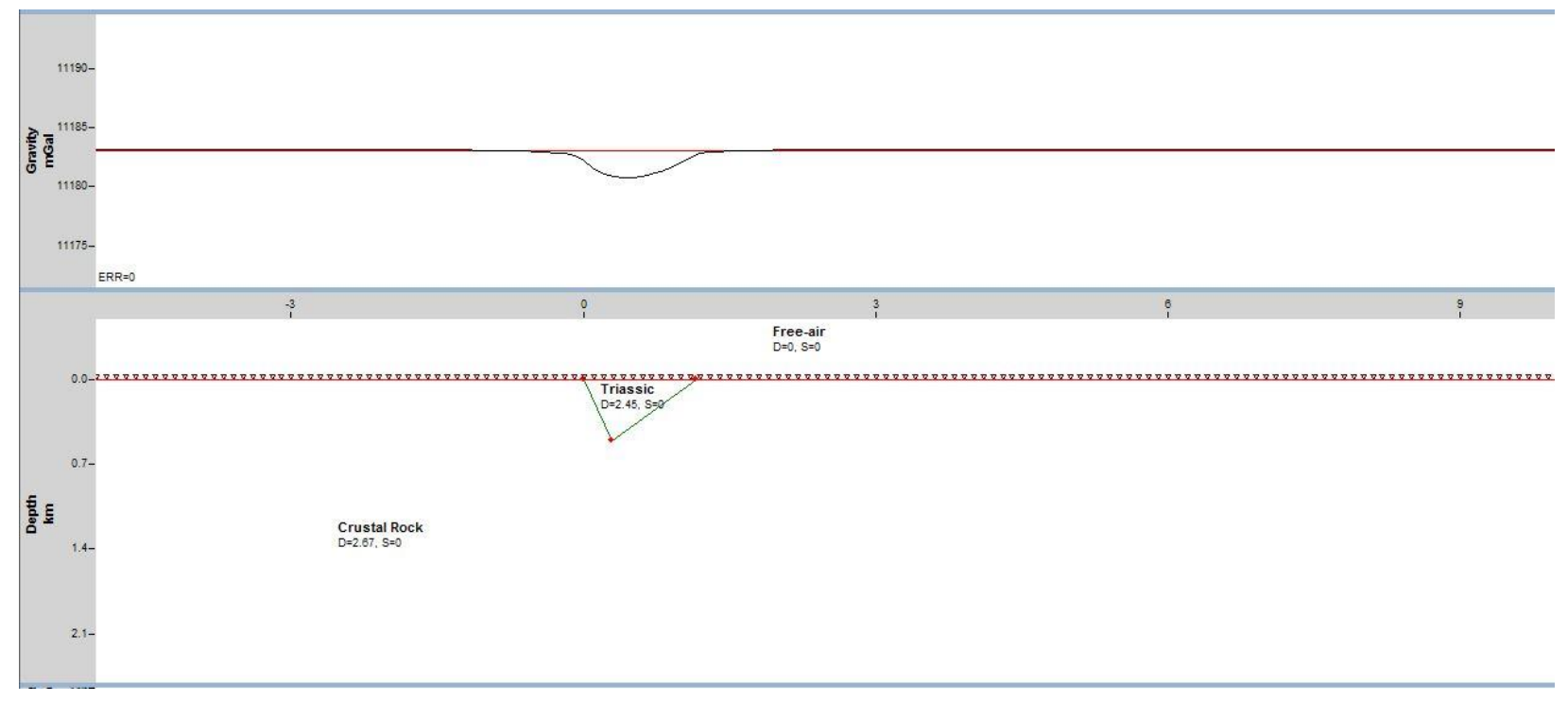

Model A1: $0.5 \mathrm{~km}$ deep basin exposed at the surface and resultant gravity anomaly. Densities of $2.45 \mathrm{gm} / \mathrm{cc}$ and $2.67 \mathrm{gm} / \mathrm{cc}$ used for Triassic strata and crustal rock, respectively.

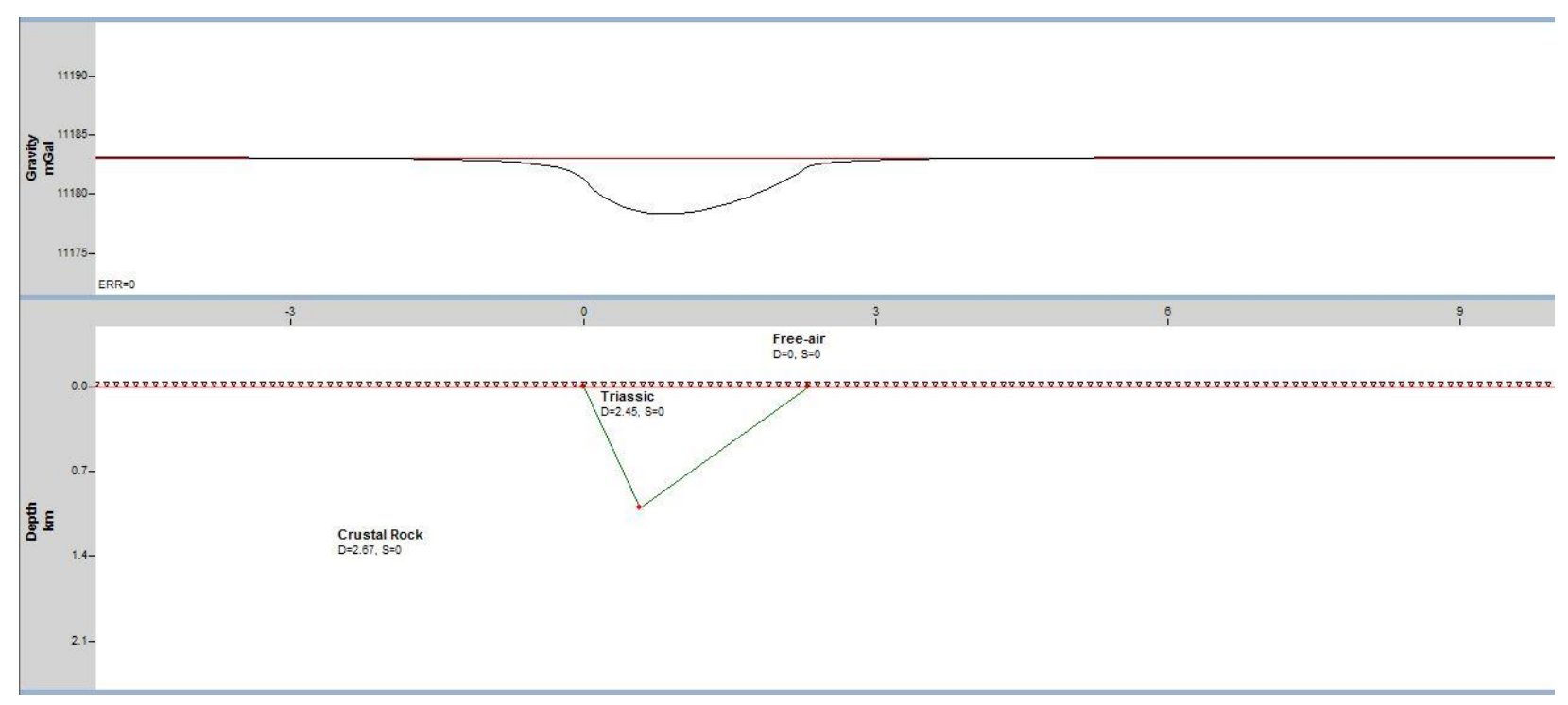

Model A2: $1.0 \mathrm{~km}$ deep basin exposed at the surface and resultant gravity anomaly. Densities of $2.45 \mathrm{gm} / \mathrm{cc}$ and $2.67 \mathrm{gm} / \mathrm{cc}$ used for Triassic strata and crustal rock, respectively. 


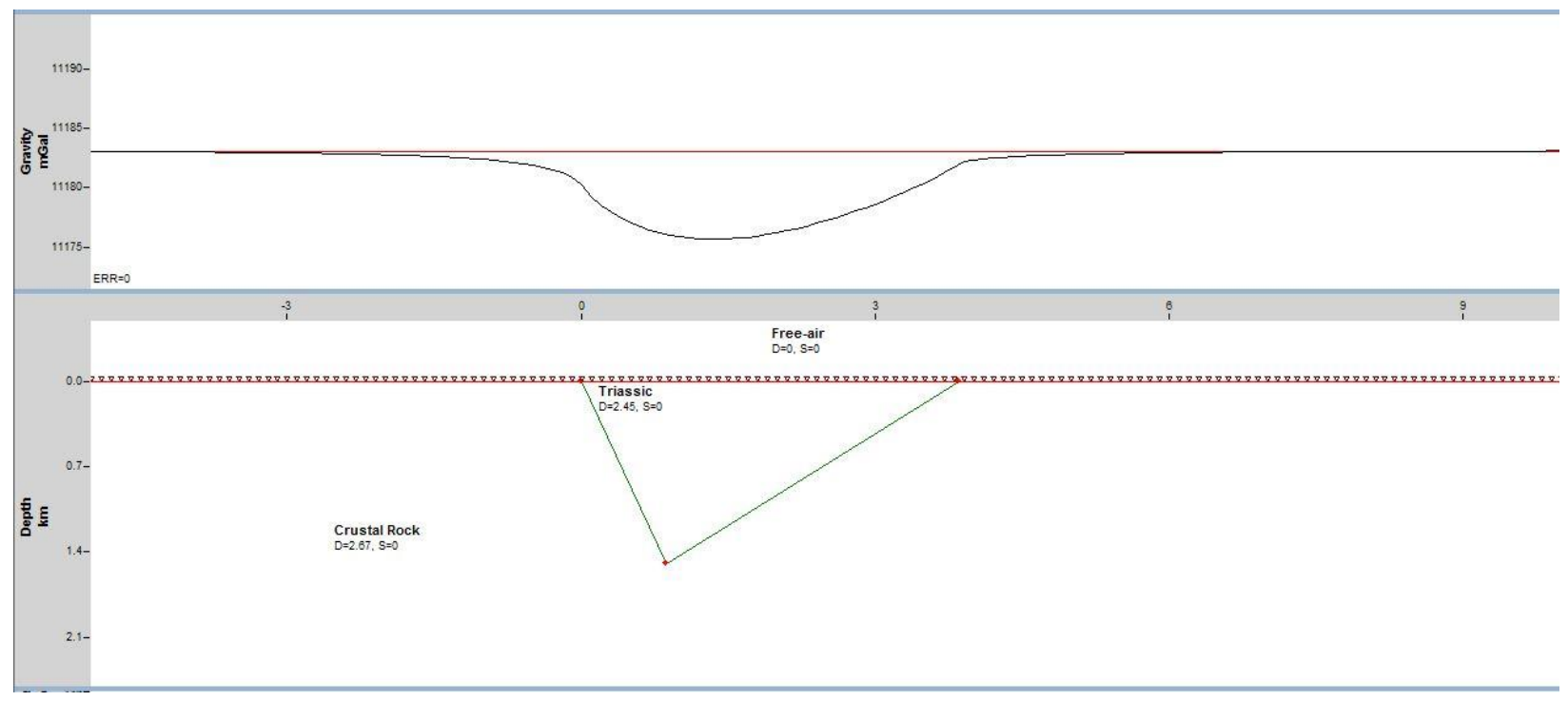

Model A3: $1.5 \mathrm{~km}$ deep basin exposed at the surface and resultant gravity anomaly. Densities of $2.45 \mathrm{gm} / \mathrm{cc}$ and $2.67 \mathrm{gm} / \mathrm{cc}$ used for Triassic strata and crustal rock, respectively.

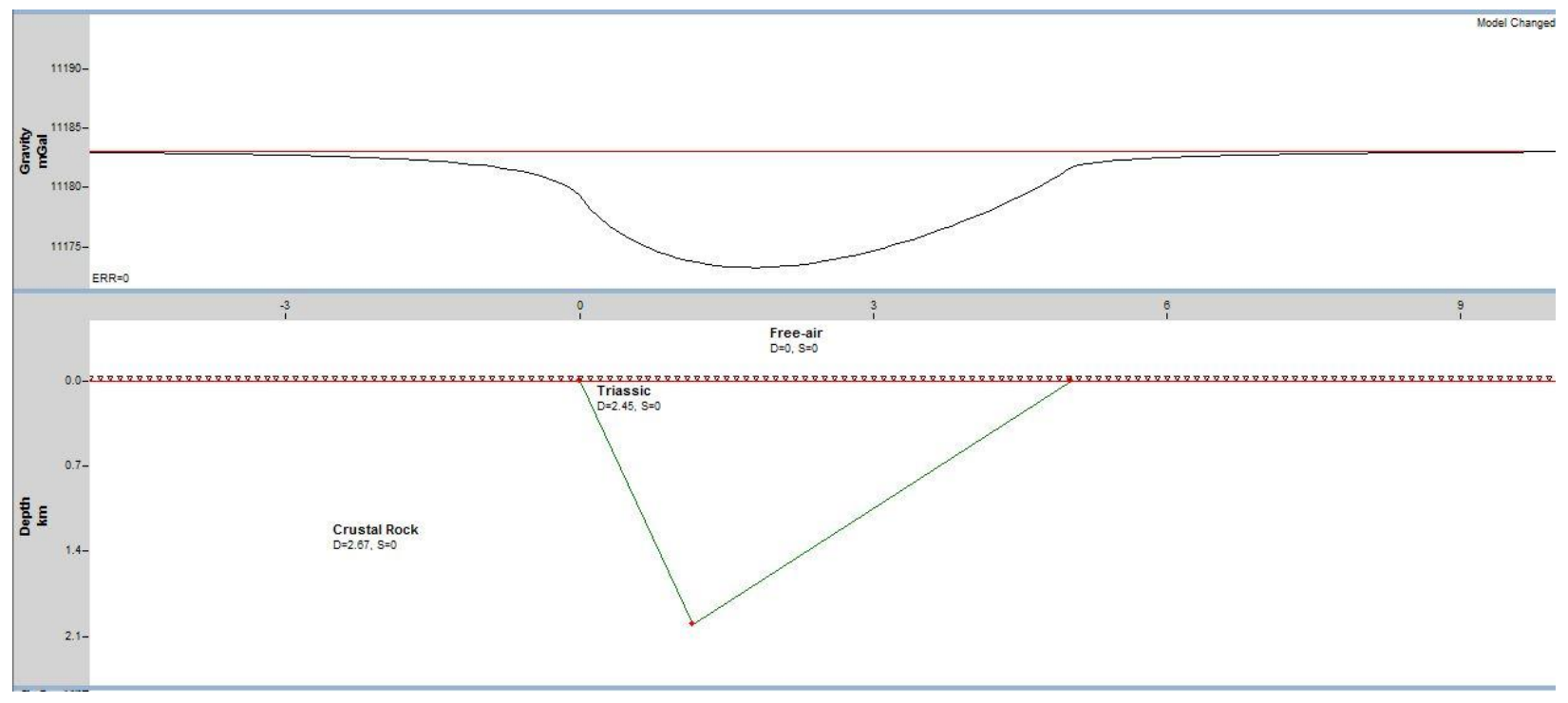

Model A4: $2.0 \mathrm{~km}$ deep basin exposed at the surface and resultant gravity anomaly. Densities of $2.45 \mathrm{gm} / \mathrm{cc}$ and $2.67 \mathrm{gm} / \mathrm{cc}$ used for Triassic strata and crustal rock, respectively. 


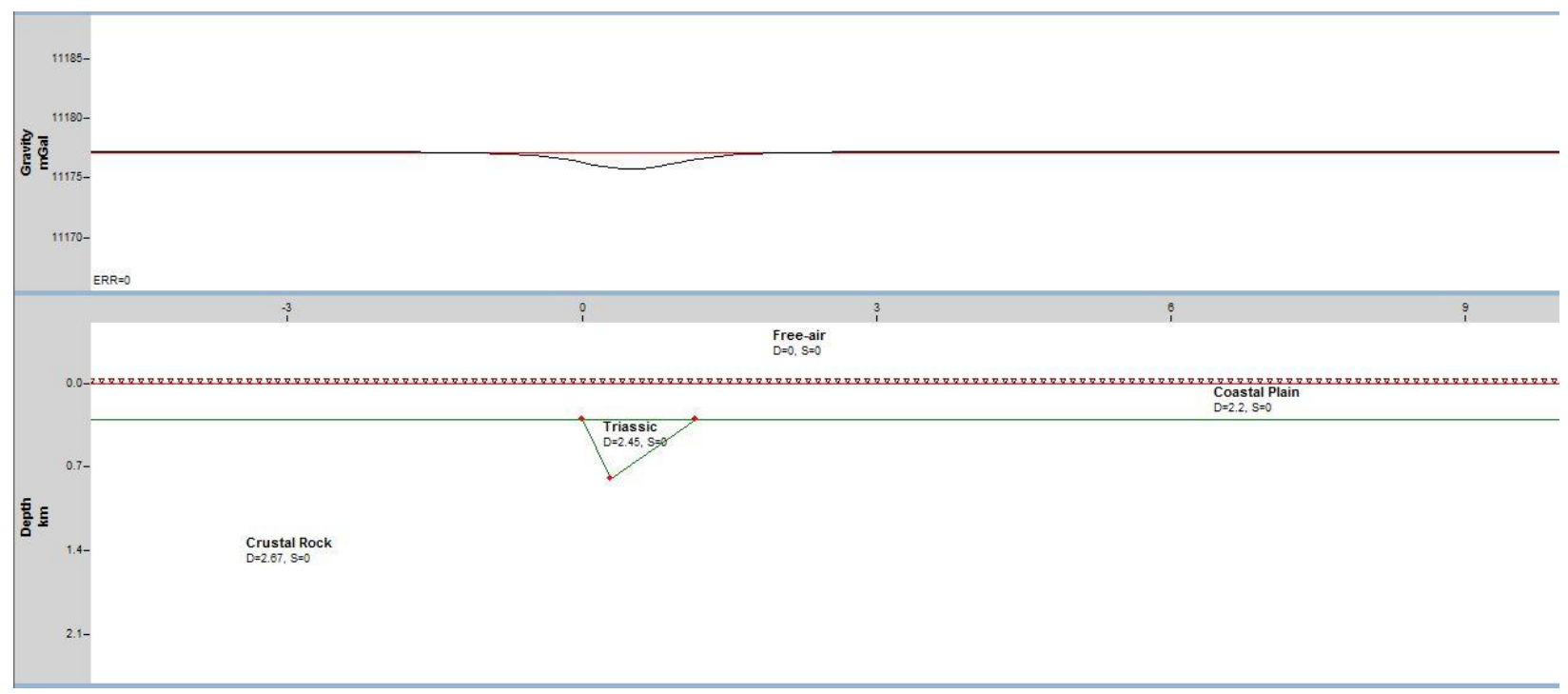

Model A5: $0.5 \mathrm{~km}$ deep basin buried at a depth of $0.3 \mathrm{~km}$ and resultant gravity anomaly. Densities of $2.2 \mathrm{gm} / \mathrm{cc}, 2.45 \mathrm{gm} / \mathrm{cc}$ and $2.67 \mathrm{gm} / \mathrm{cc}$ used for overlying sediments, Triassic strata and crustal rock, respectively.

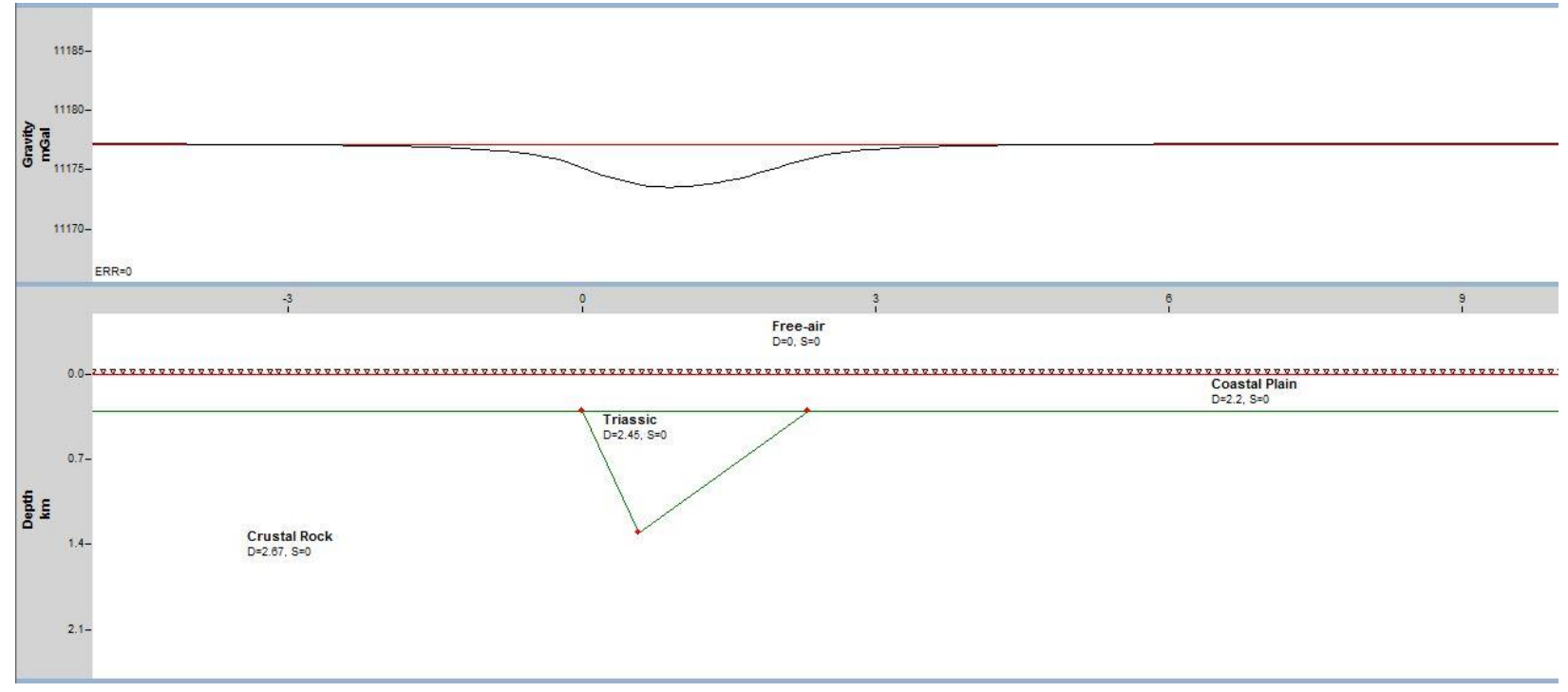

Model A6: $1.0 \mathrm{~km}$ deep basin buried at a depth of $0.3 \mathrm{~km}$ and resultant gravity anomaly. Densities of $2.2 \mathrm{gm} / \mathrm{cc}, 2.45 \mathrm{gm} / \mathrm{cc}$ and $2.67 \mathrm{gm} / \mathrm{cc}$ used for overlying sediments, Triassic strata and crustal rock, respectively. 


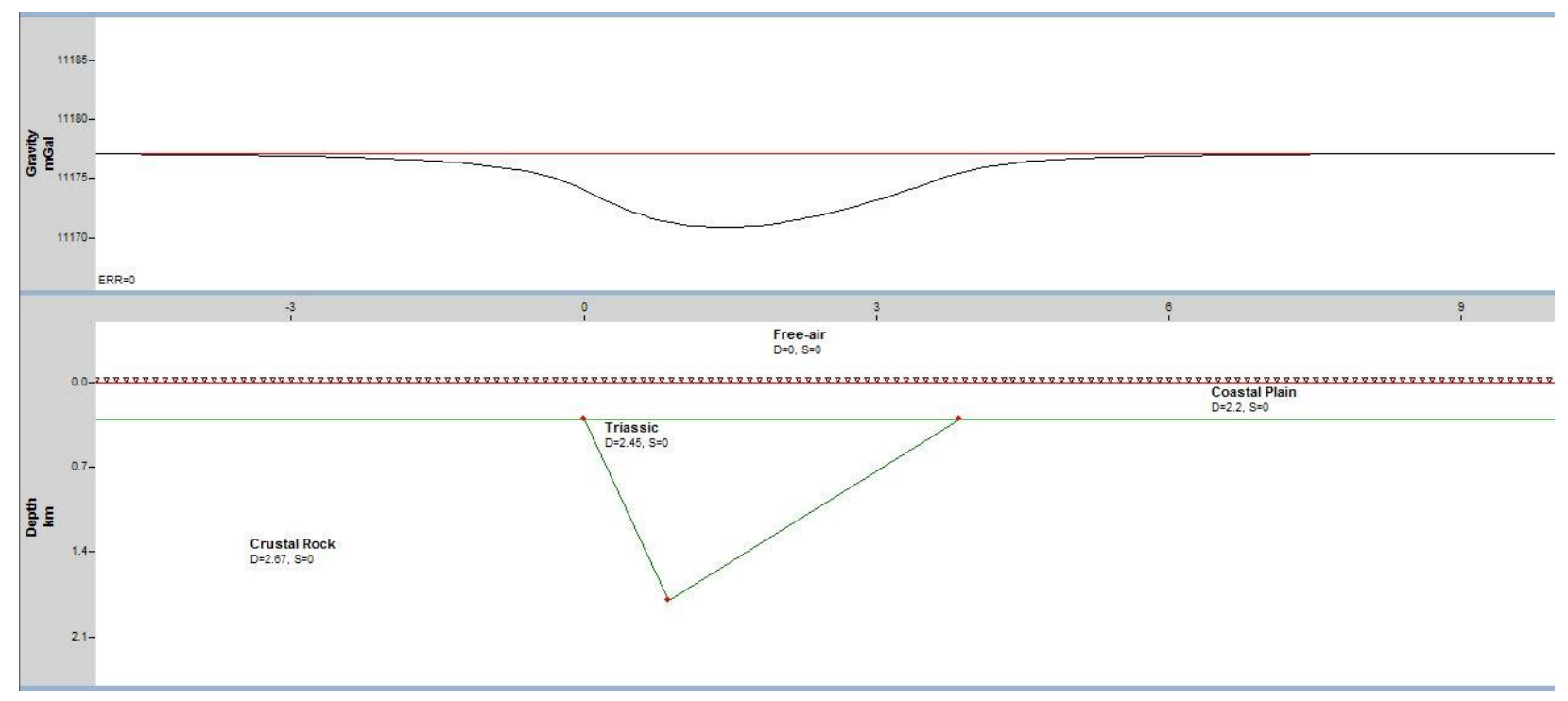

Model A7: $1.5 \mathrm{~km}$ deep basin buried at a depth of $0.3 \mathrm{~km}$ and resultant gravity anomaly. Densities of $2.2 \mathrm{gm} / \mathrm{cc}, 2.45 \mathrm{gm} / \mathrm{cc}$ and $2.67 \mathrm{gm} / \mathrm{cc}$ used for overlying sediments, Triassic strata and crustal rock, respectively.

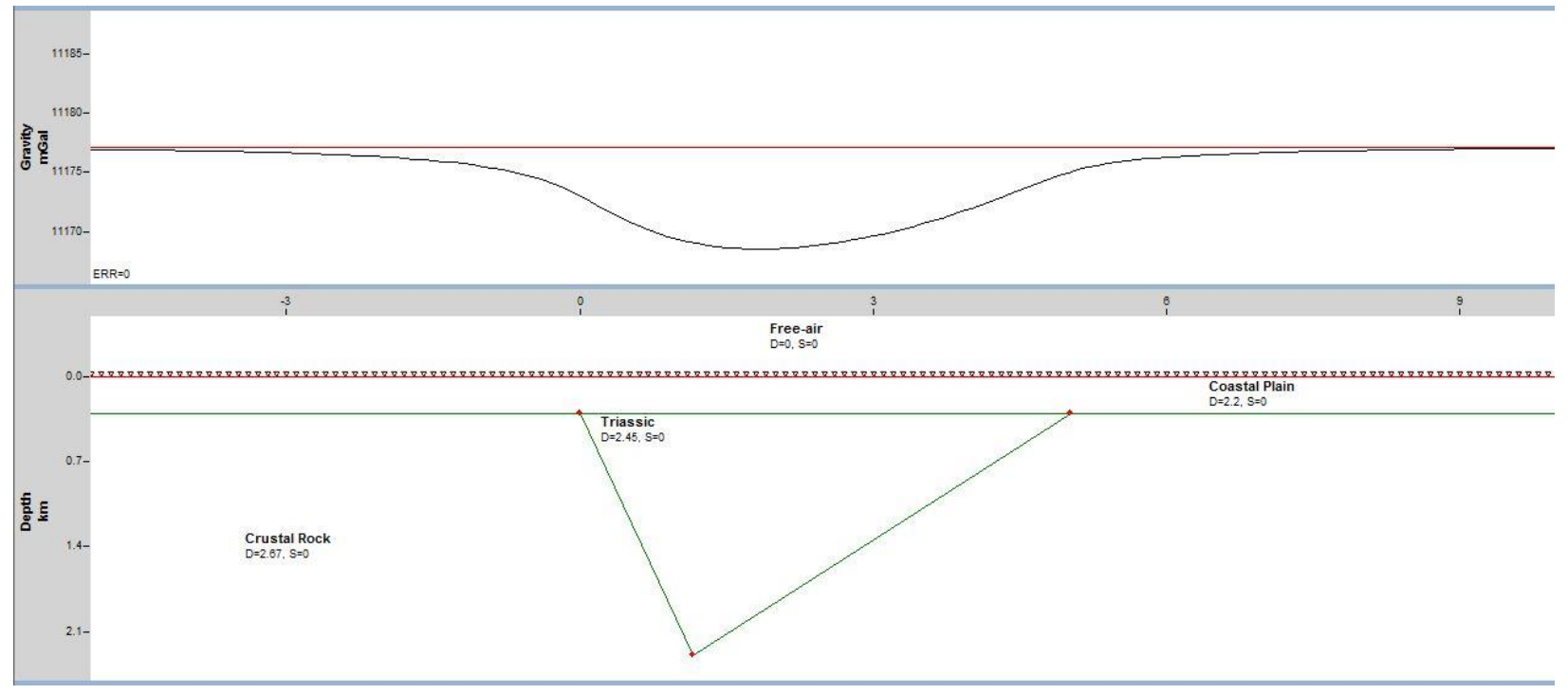

Model A8: $2.0 \mathrm{~km}$ deep basin buried at a depth of $0.3 \mathrm{~km}$ and resultant gravity anomaly. Densities of $2.2 \mathrm{gm} / \mathrm{cc}, 2.45 \mathrm{gm} / \mathrm{cc}$ and $2.67 \mathrm{gm} / \mathrm{cc}$ used for overlying sediments, Triassic strata and crustal rock, respectively. 


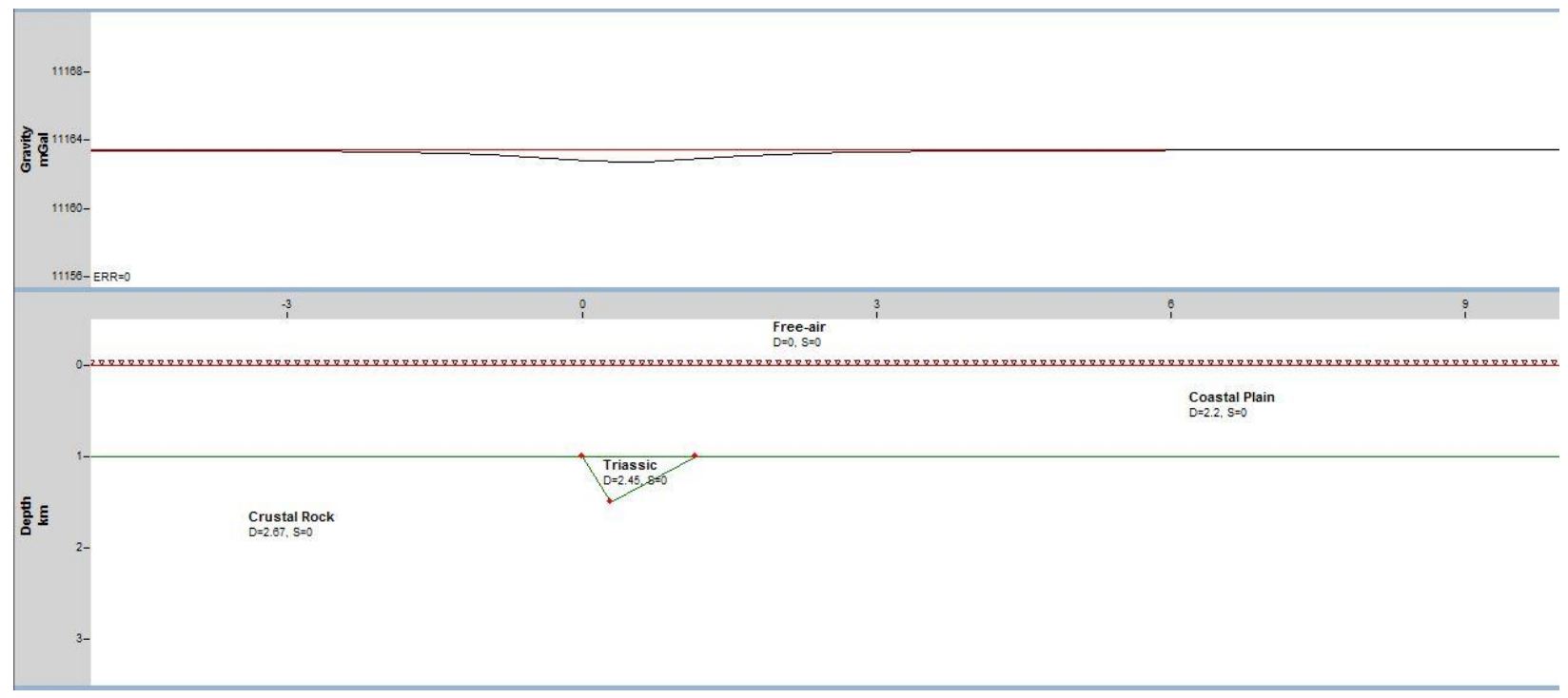

Model A9: $0.5 \mathrm{~km}$ deep basin buried at a depth of $1.0 \mathrm{~km}$ and resultant gravity anomaly.

Densities of $2.2 \mathrm{gm} / \mathrm{cc}, 2.45 \mathrm{gm} / \mathrm{cc}$ and $2.67 \mathrm{gm} / \mathrm{cc}$ used for overlying sediments, Triassic strata and crustal rock, respectively.

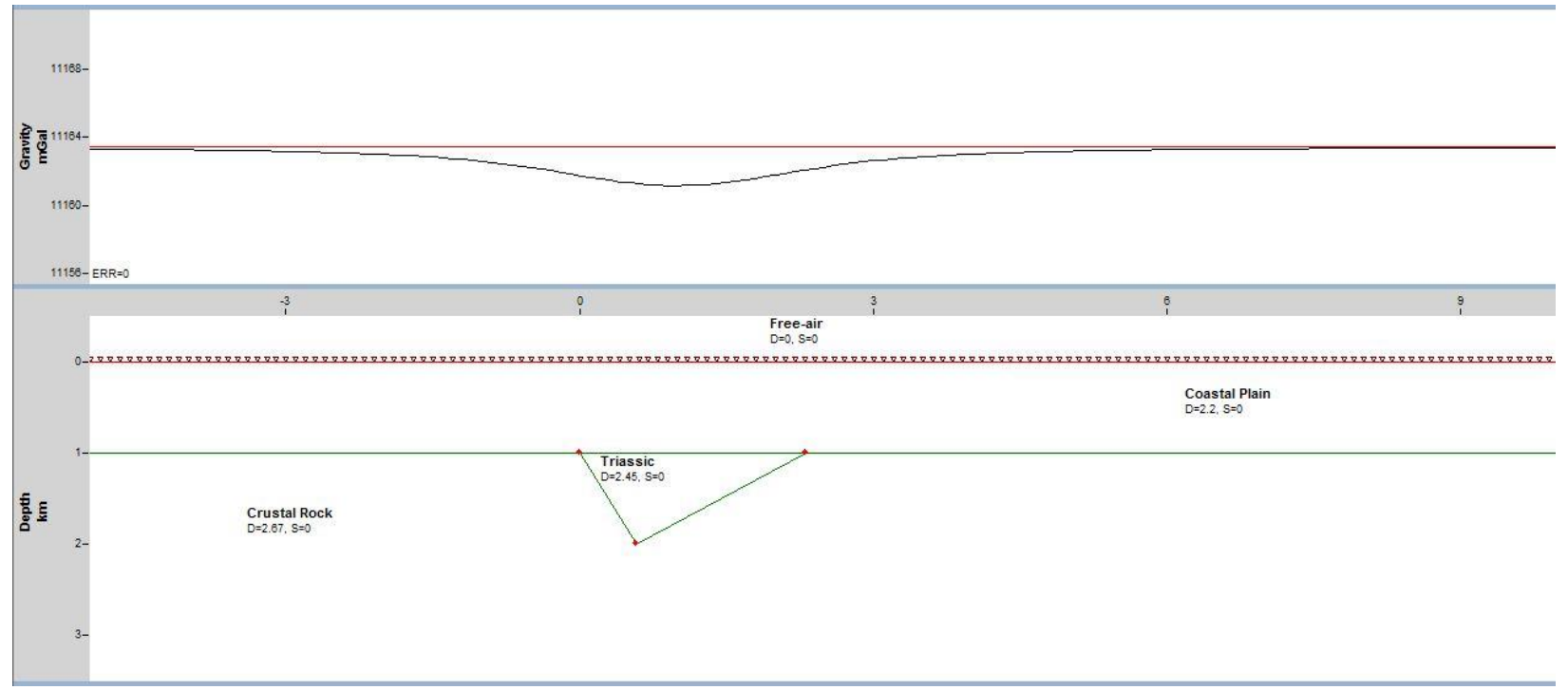

Model A10: $1.0 \mathrm{~km}$ deep basin buried at a depth of $1.0 \mathrm{~km}$ and resultant gravity anomaly. Densities of $2.2 \mathrm{gm} / \mathrm{cc}, 2.45 \mathrm{gm} / \mathrm{cc}$ and $2.67 \mathrm{gm} / \mathrm{cc}$ used for overlying sediments, Triassic strata and crustal rock, respectively. 


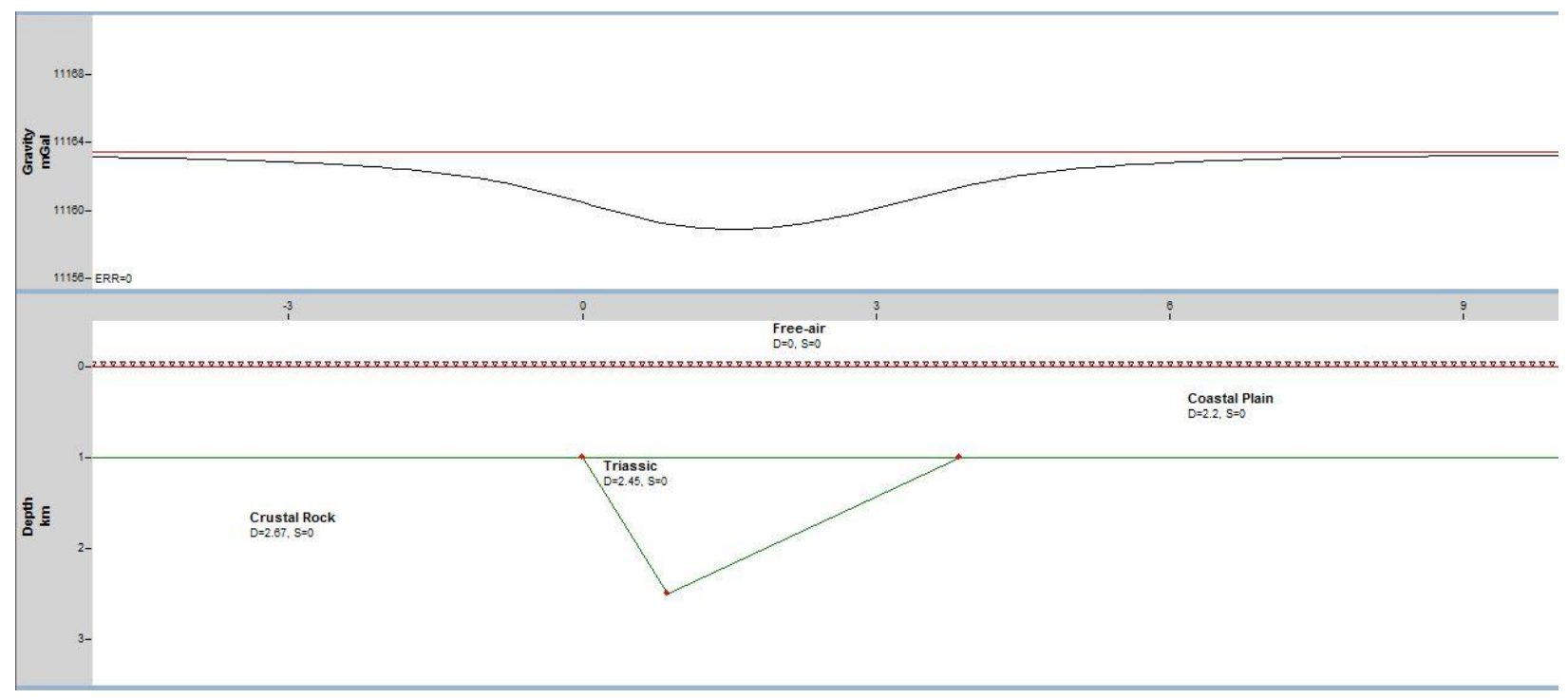

Model A11: $1.5 \mathrm{~km}$ deep basin buried at a depth of $1.0 \mathrm{~km}$ and resultant gravity anomaly. Densities of $2.2 \mathrm{gm} / \mathrm{cc}, 2.45 \mathrm{gm} / \mathrm{cc}$ and $2.67 \mathrm{gm} / \mathrm{cc}$ used for overlying sediments, Triassic strata and crustal rock, respectively.

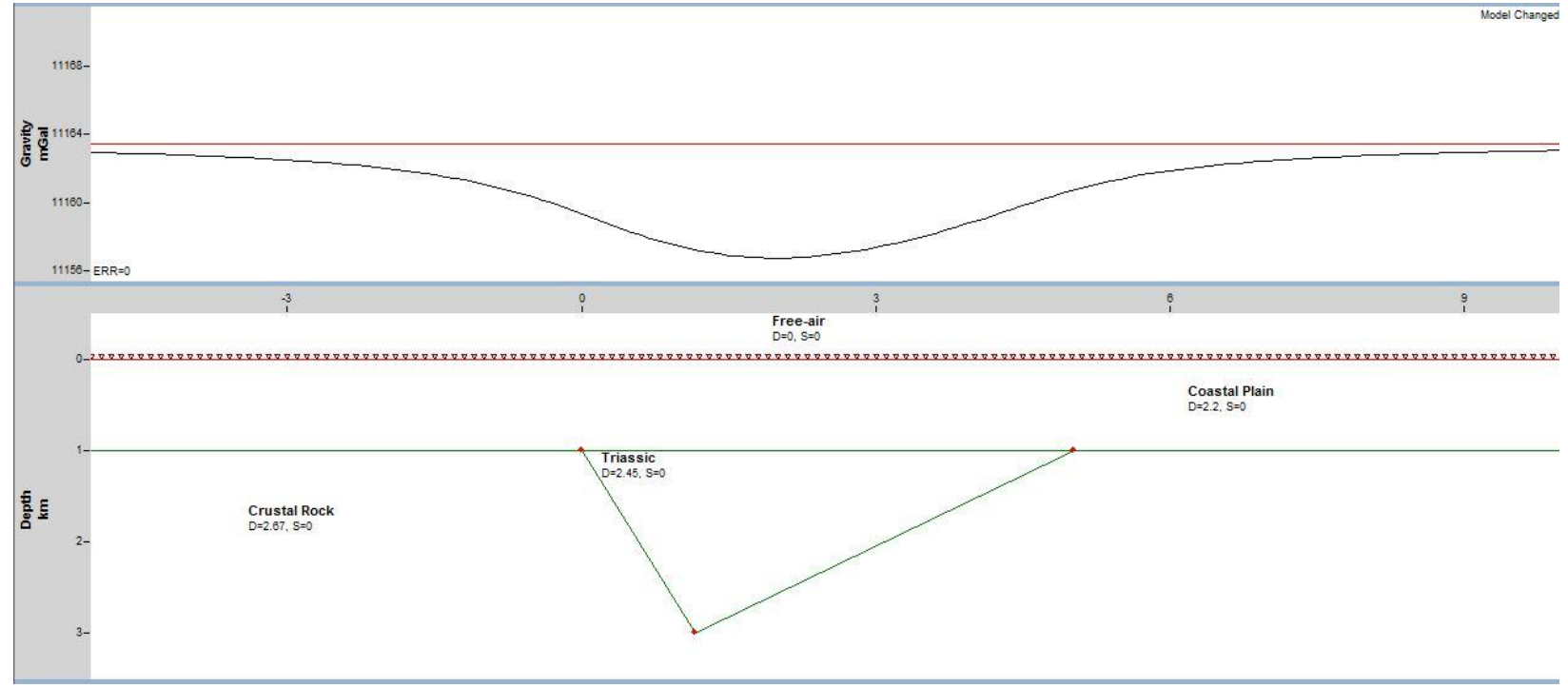

Model A12: $2.0 \mathrm{~km}$ deep basin buried at a depth of $1.0 \mathrm{~km}$ and resultant gravity anomaly. Densities of $2.2 \mathrm{gm} / \mathrm{cc}, 2.45 \mathrm{gm} / \mathrm{cc}$ and $2.67 \mathrm{gm} / \mathrm{cc}$ used for overlying sediments, Triassic strata and crustal rock, respectively. 
Sensitivity to density of Triassic strata:

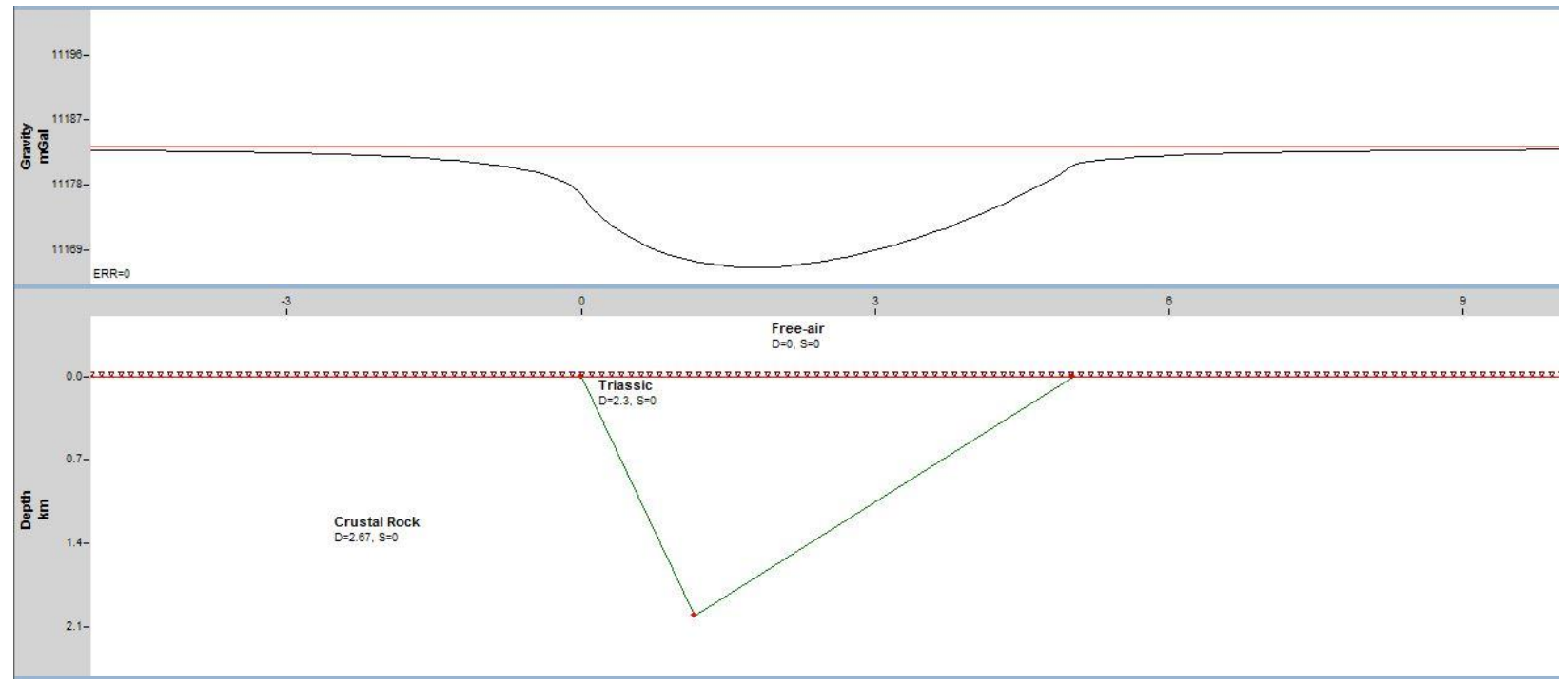

Model B1: $2.0 \mathrm{~km}$ deep basin exposed at the surface and resultant gravity anomaly. Densities of $2.3 \mathrm{gm} / \mathrm{cc}$ and $2.67 \mathrm{gm} / \mathrm{cc}$ used for the Triassic strata and crustal rock, respectively.

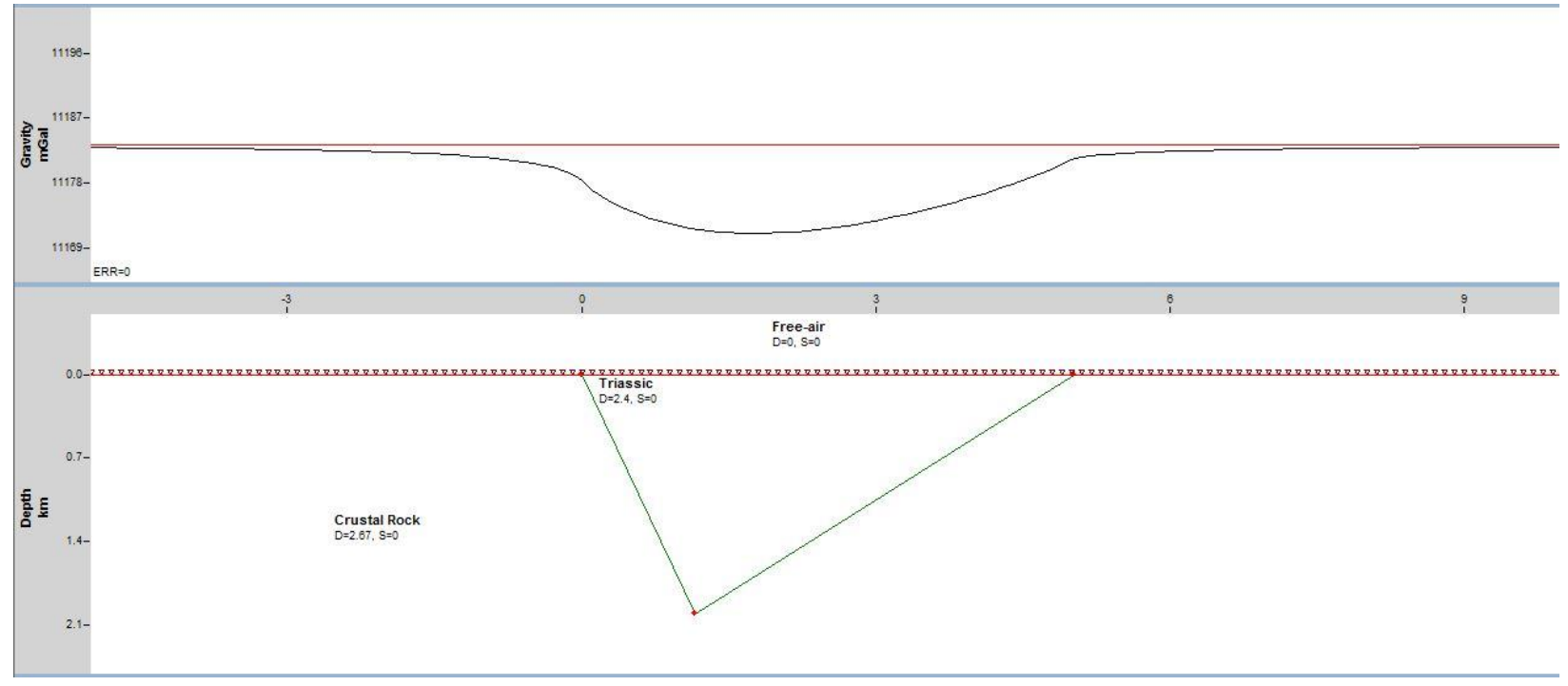

Model B2: $2.0 \mathrm{~km}$ deep basin exposed at the surface and resultant gravity anomaly. Densities of $2.4 \mathrm{gm} / \mathrm{cc}$ and $2.67 \mathrm{gm} / \mathrm{cc}$ used for the Triassic strata and crustal rock, respectively. 


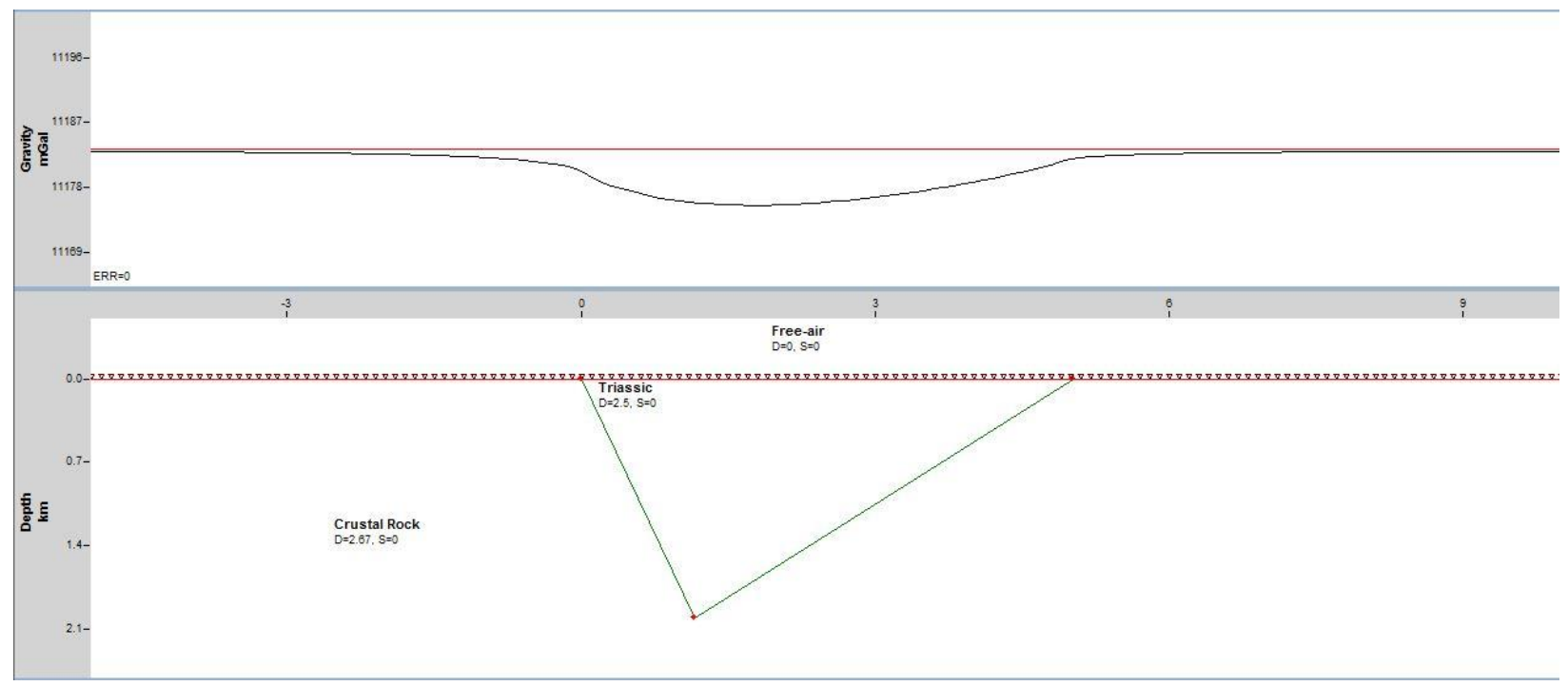

Model B3: $2.0 \mathrm{~km}$ deep basin exposed at the surface and resultant gravity anomaly. Densities of $2.5 \mathrm{gm} / \mathrm{cc}$ and $2.67 \mathrm{gm} / \mathrm{cc}$ used for the Triassic strata and crustal rock, respectively.

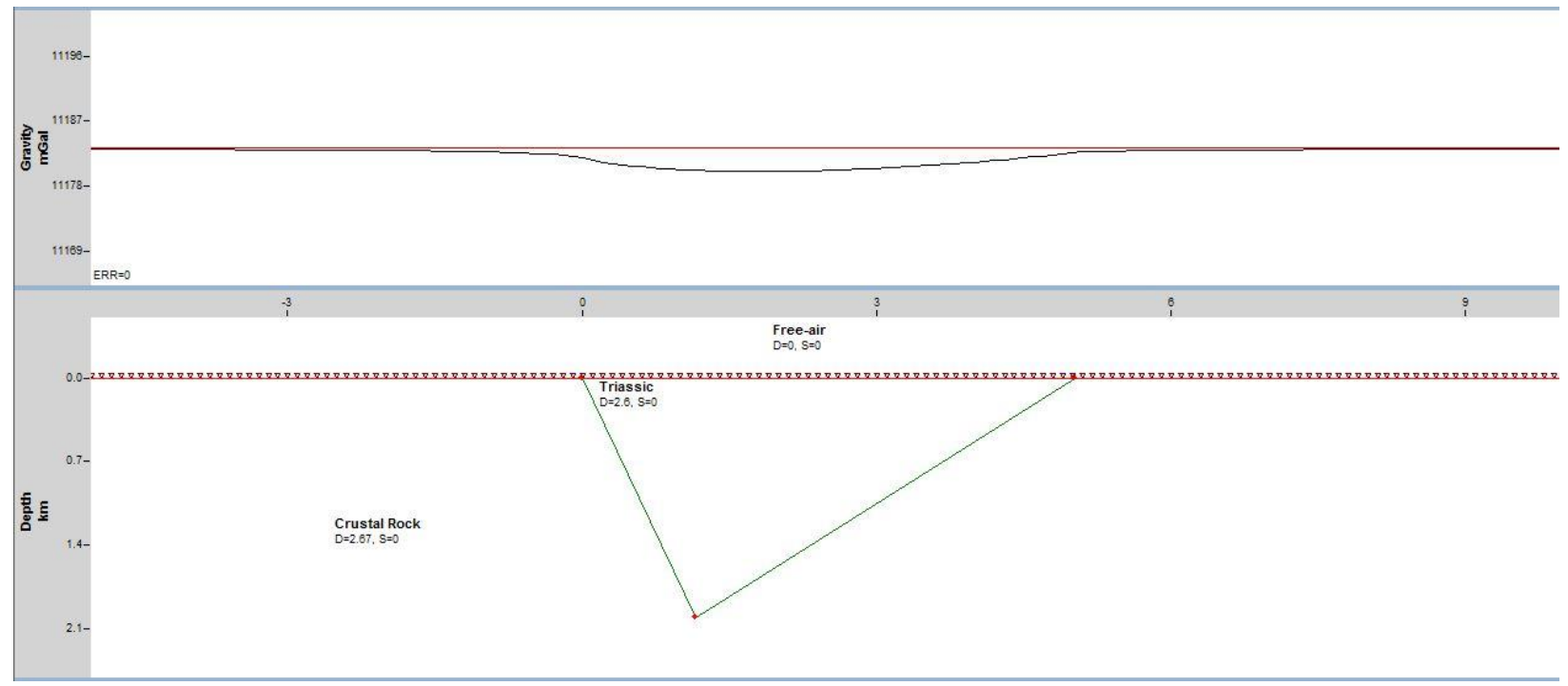

Model B4: $2.0 \mathrm{~km}$ deep basin exposed at the surface and resultant gravity anomaly. Densities of $2.6 \mathrm{gm} / \mathrm{cc}$ and $2.67 \mathrm{gm} / \mathrm{cc}$ used for the Triassic strata and crustal rock, respectively. 


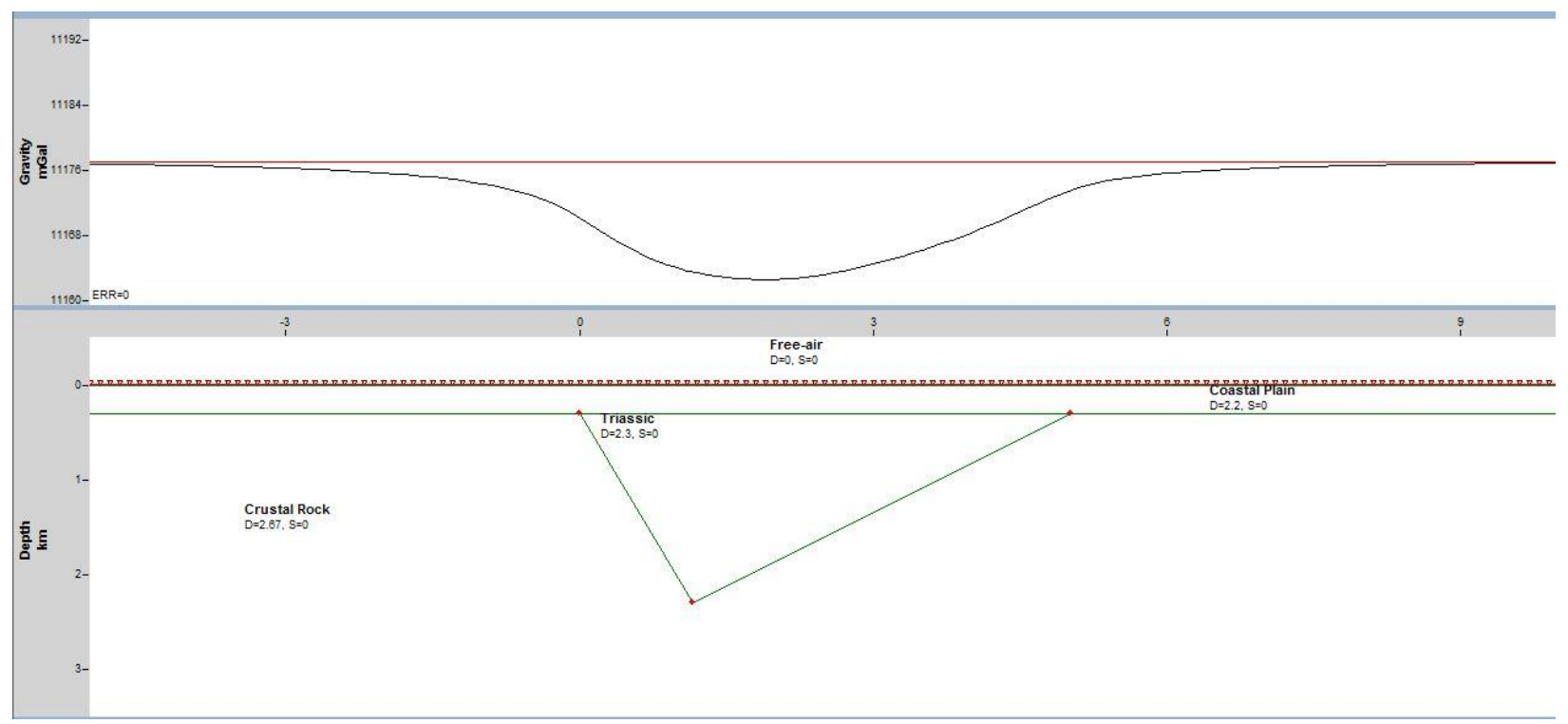

Model B5: $2.0 \mathrm{~km}$ deep basin buried at $0.3 \mathrm{~km}$ and resultant gravity anomaly. Densities of 2.2 $\mathrm{gm} / \mathrm{cc}, 2.3 \mathrm{gm} / \mathrm{cc}$ and $2.67 \mathrm{gm} / \mathrm{cc}$ used for the overlying sediments, Triassic strata and crustal rock, respectively.

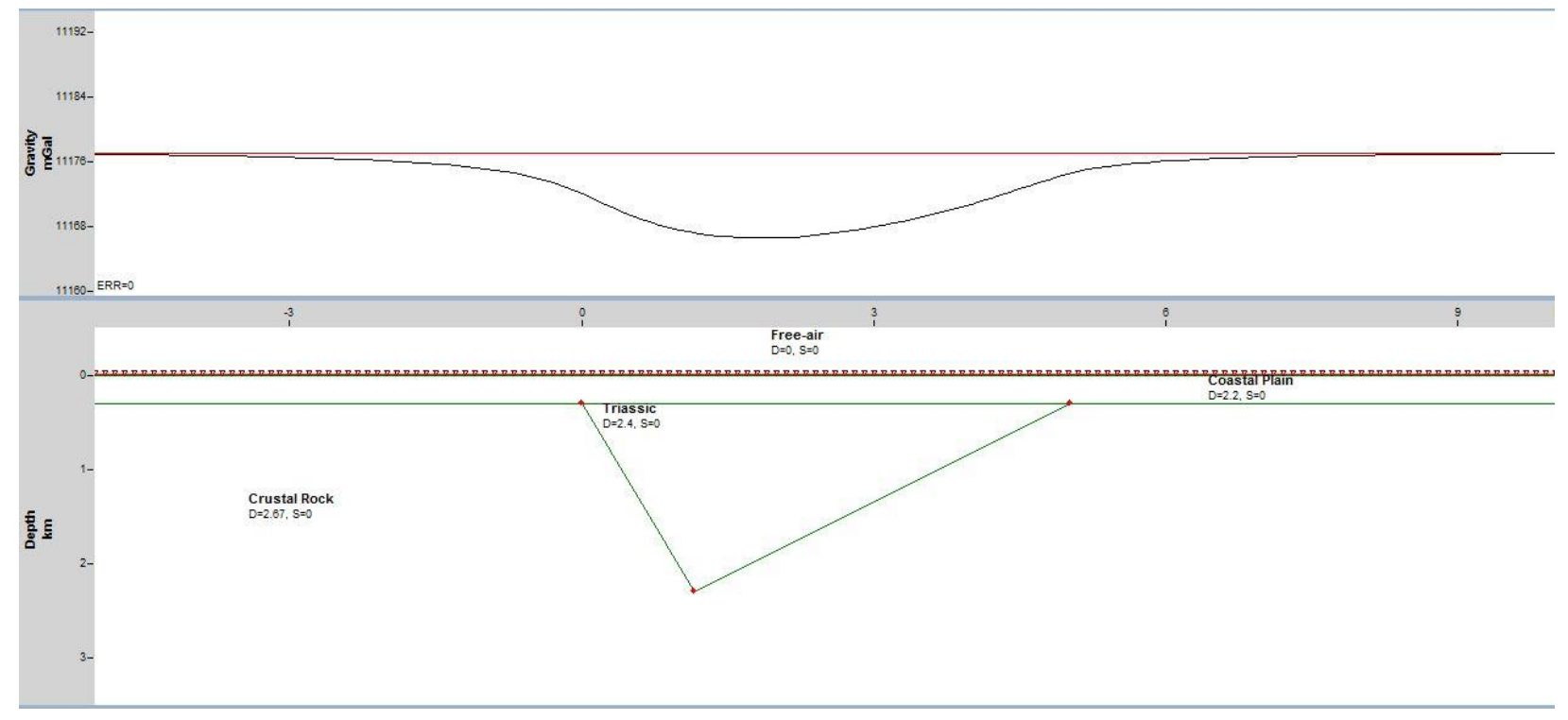

Model B6: $2.0 \mathrm{~km}$ deep basin buried at $0.3 \mathrm{~km}$ and resultant gravity anomaly. Densities of 2.2 $\mathrm{gm} / \mathrm{cc}, 2.4 \mathrm{gm} / \mathrm{cc}$ and $2.67 \mathrm{gm} / \mathrm{cc}$ used for the overlying sediments, Triassic strata and crustal rock, respectively. 


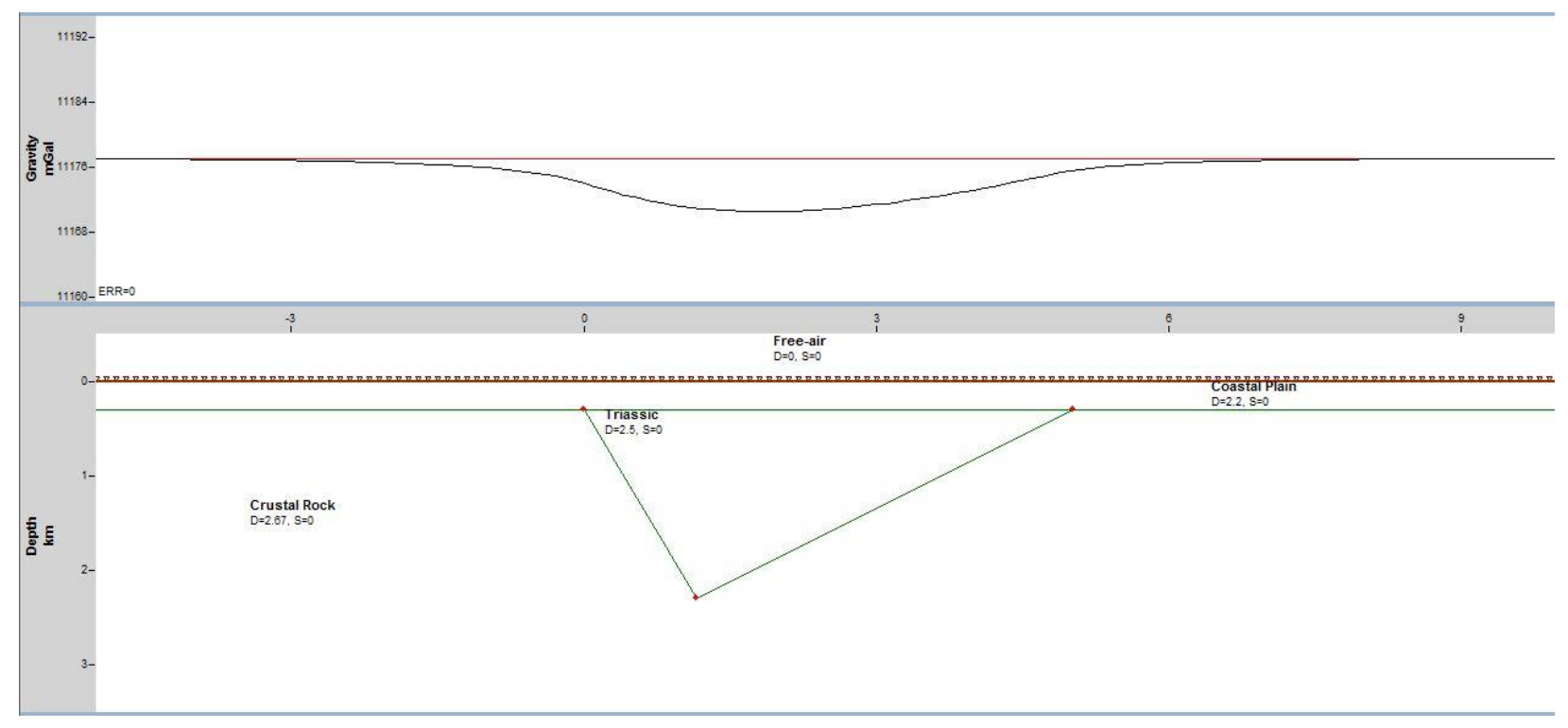

Model B7: $2.0 \mathrm{~km}$ deep basin buried at $0.3 \mathrm{~km}$ and resultant gravity anomaly. Densities of 2.2 $\mathrm{gm} / \mathrm{cc}, 2.5 \mathrm{gm} / \mathrm{cc}$ and $2.67 \mathrm{gm} / \mathrm{cc}$ used for the overlying sediments, Triassic strata and crustal rock, respectively.

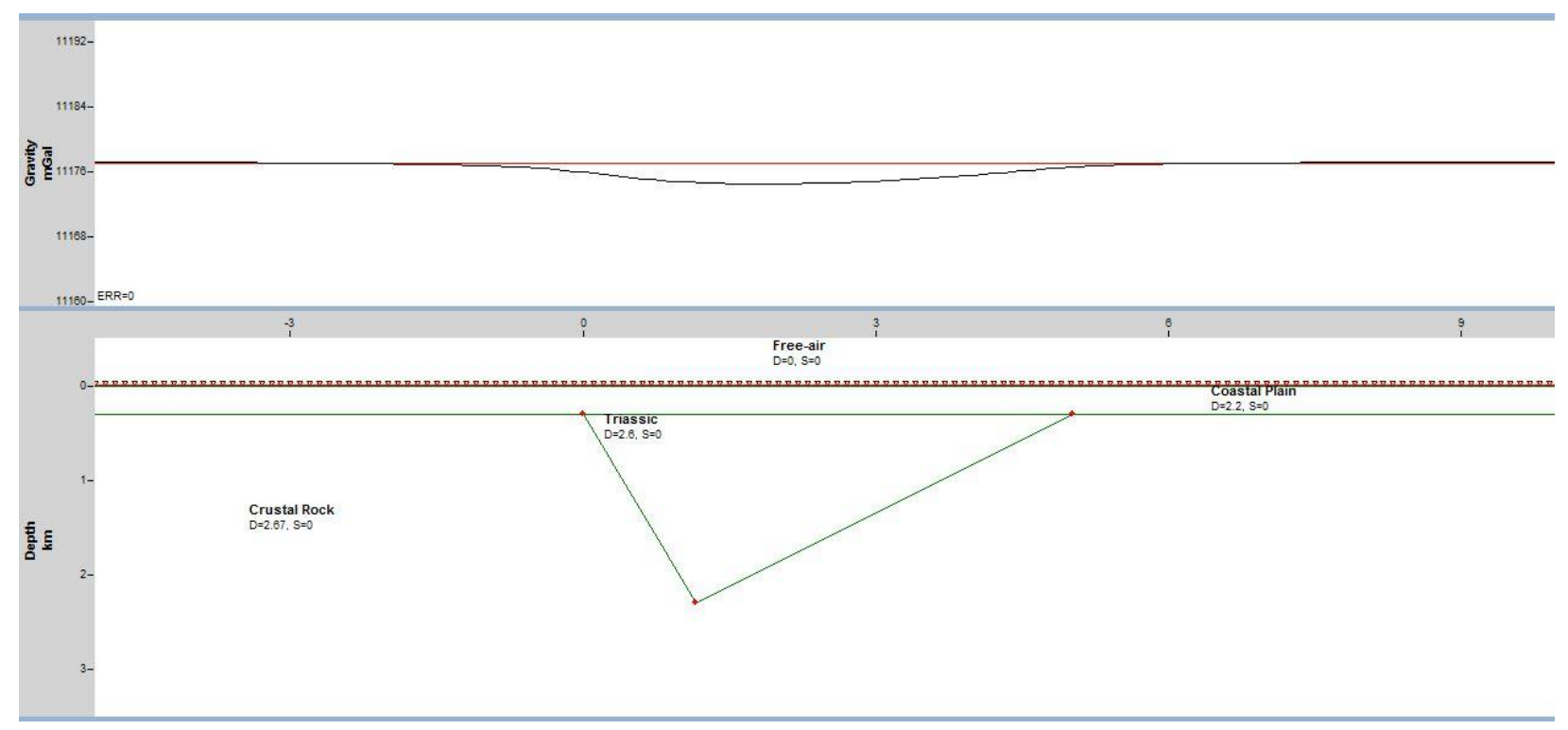

Model B8: $2.0 \mathrm{~km}$ deep basin buried at $0.3 \mathrm{~km}$ and resultant gravity anomaly. Densities of 2.2 $\mathrm{gm} / \mathrm{cc}, 2.6 \mathrm{gm} / \mathrm{cc}$ and $2.67 \mathrm{gm} / \mathrm{cc}$ used for the overlying sediments, Triassic strata and crustal rock, respectively. 


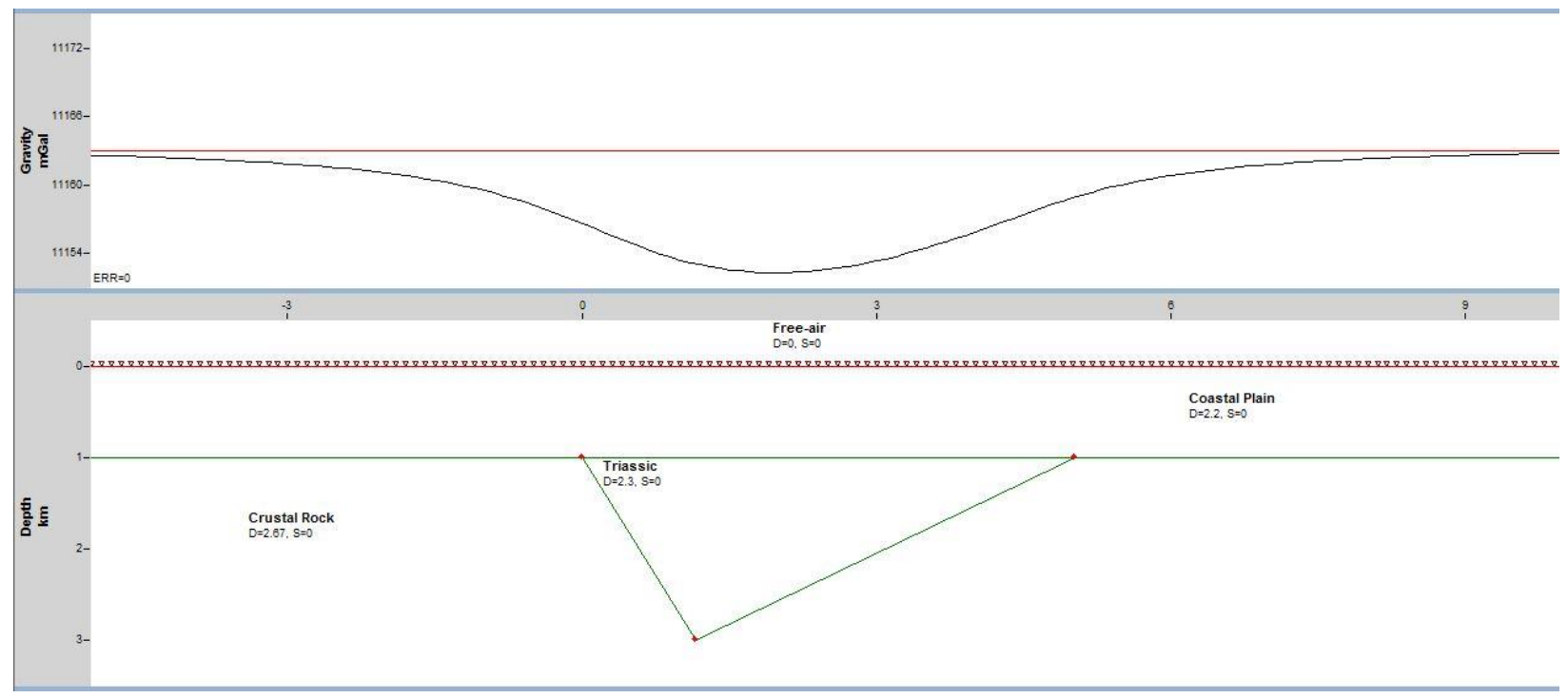

Model B9: $2.0 \mathrm{~km}$ deep basin buried at $1.0 \mathrm{~km}$ and resultant gravity anomaly. Densities of 2.2 $\mathrm{gm} / \mathrm{cc}, 2.3 \mathrm{gm} / \mathrm{cc}$ and $2.67 \mathrm{gm} / \mathrm{cc}$ used for the overlying sediments, Triassic strata and crustal rock, respectively.

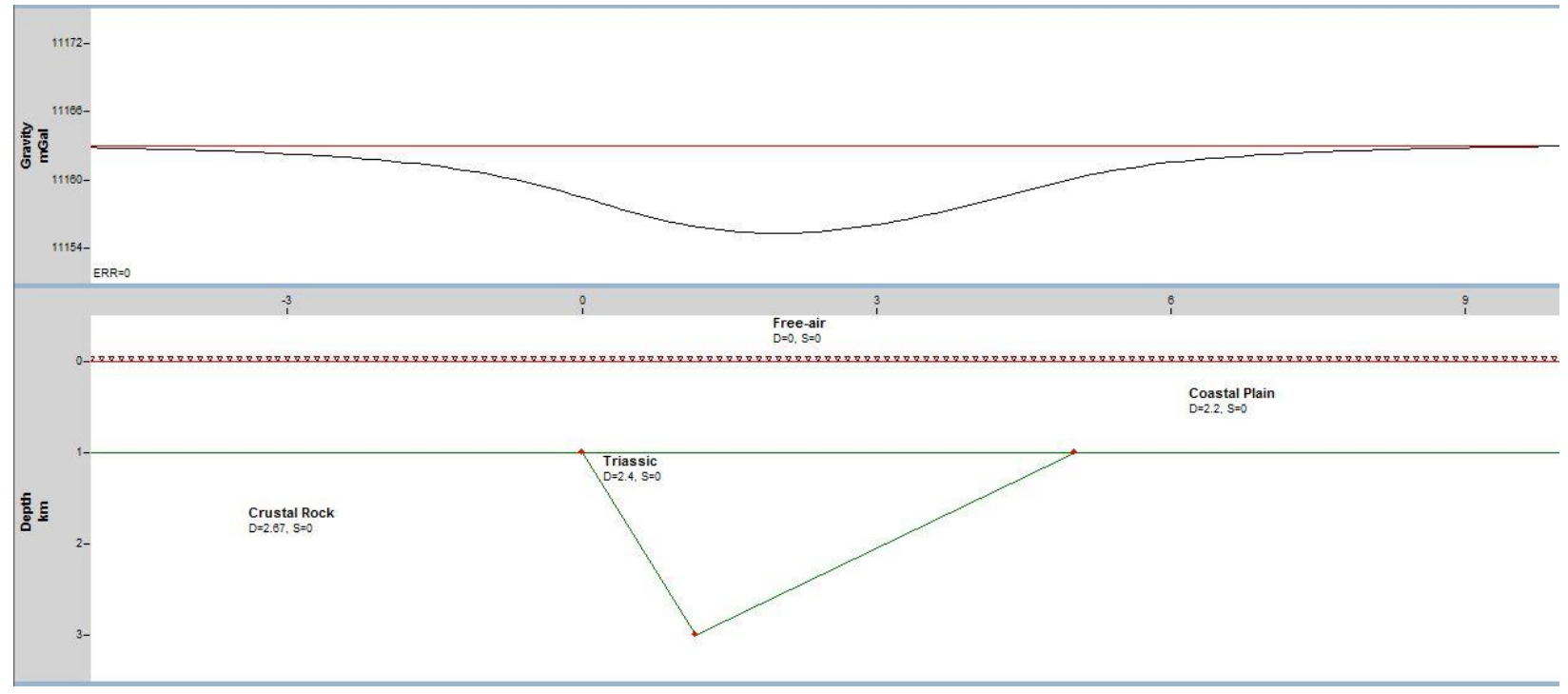

Model B10: $2.0 \mathrm{~km}$ deep basin buried at $0.3 \mathrm{~km}$ and resultant gravity anomaly. Densities of 2.2 $\mathrm{gm} / \mathrm{cc}, 2.4 \mathrm{gm} / \mathrm{cc}$ and $2.67 \mathrm{gm} / \mathrm{cc}$ used for the overlying sediments, Triassic strata and crustal rock, respectively. 


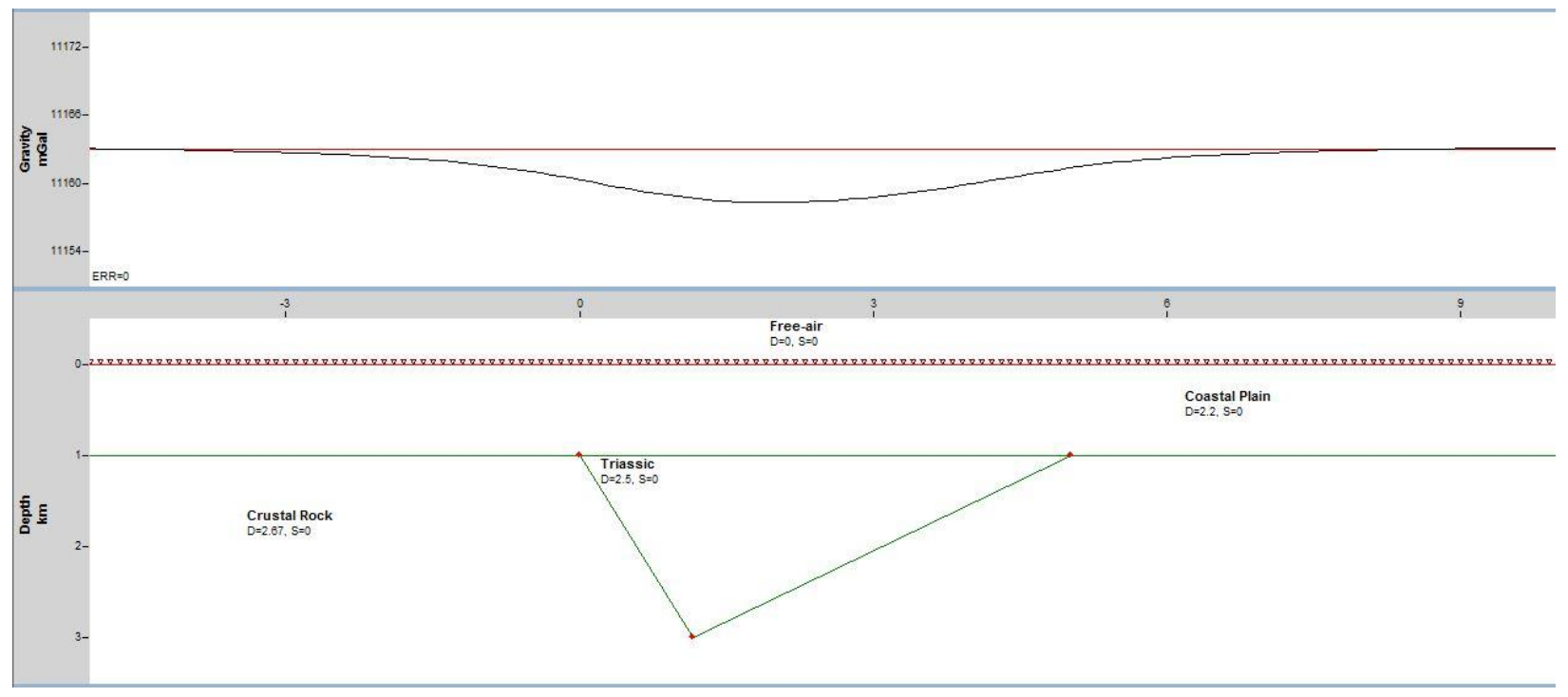

Model B11: $2.0 \mathrm{~km}$ deep basin buried at $0.3 \mathrm{~km}$ and resultant gravity anomaly. Densities of 2.2 $\mathrm{gm} / \mathrm{cc}, 2.5 \mathrm{gm} / \mathrm{cc}$ and $2.67 \mathrm{gm} / \mathrm{cc}$ used for the overlying sediments, Triassic strata and crustal rock, respectively.

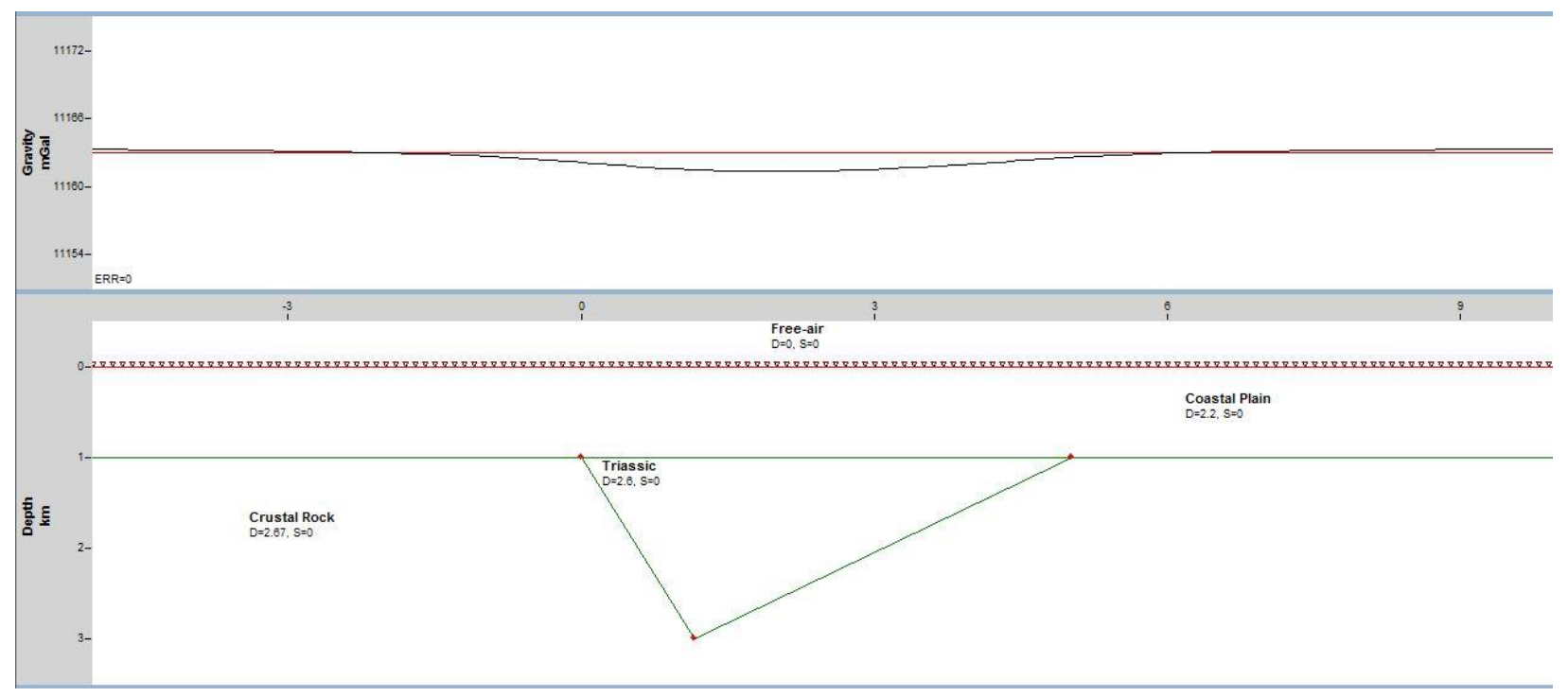

Model B12: $2.0 \mathrm{~km}$ deep basin buried at $0.3 \mathrm{~km}$ and resultant gravity anomaly. Densities of 2.2 $\mathrm{gm} / \mathrm{cc}, 2.6 \mathrm{gm} / \mathrm{cc}$ and $2.67 \mathrm{gm} / \mathrm{cc}$ used for the overlying sediments, Triassic strata and crustal rock, respectively. 
Sensitivity to density of Coastal Plain strata:

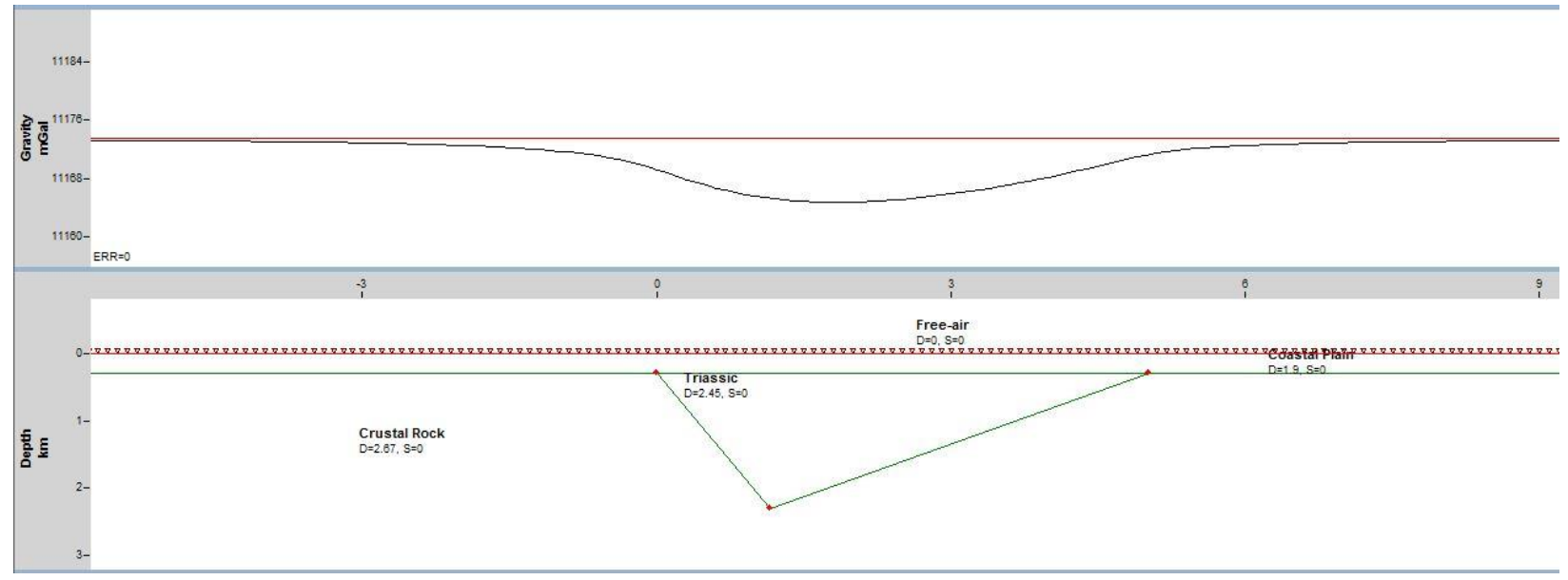

Model C1: $2.0 \mathrm{~km}$ deep basin buried at $0.3 \mathrm{~km}$ and resultant gravity anomaly. Densities of 1.9 $\mathrm{gm} / \mathrm{cc}, 2.45 \mathrm{gm} / \mathrm{cc}$ and $2.67 \mathrm{gm} / \mathrm{cc}$ used for the overlying sediments, Triassic strata and crustal rock, respectively.

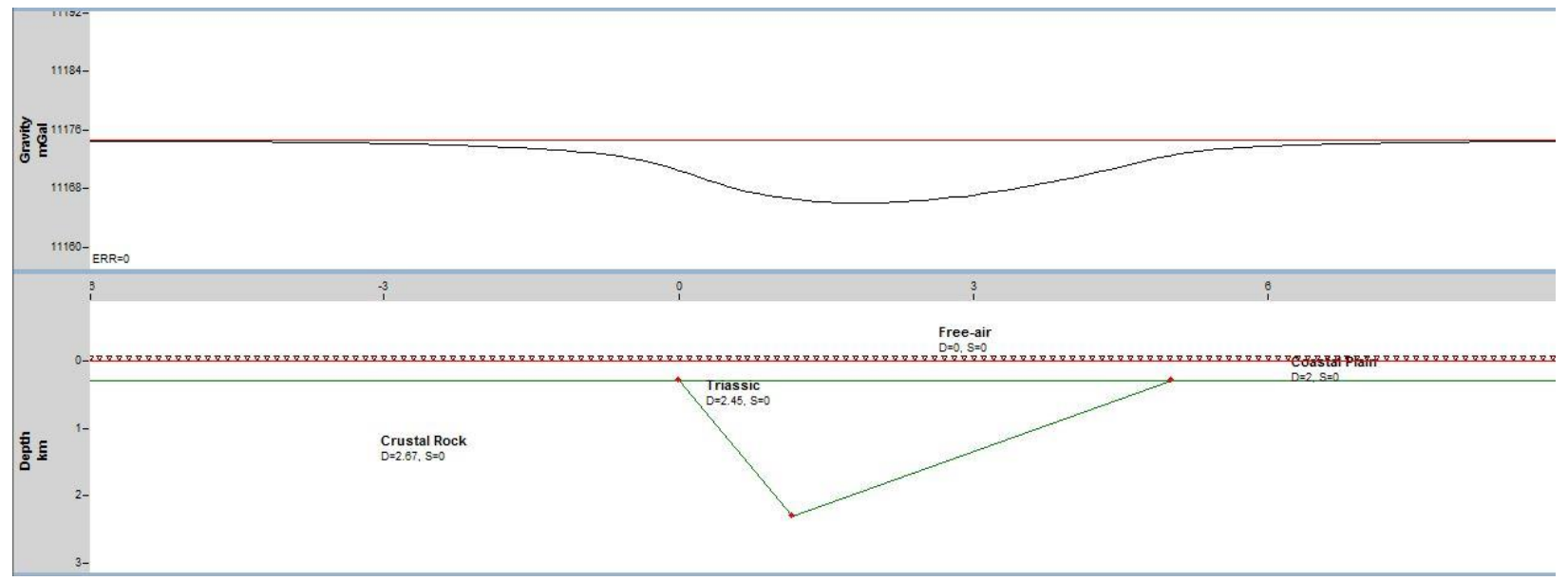

Model C2: $2.0 \mathrm{~km}$ deep basin buried at $0.3 \mathrm{~km}$ and resultant gravity anomaly. Densities of 2.0 $\mathrm{gm} / \mathrm{cc}, 2.45 \mathrm{gm} / \mathrm{cc}$ and $2.67 \mathrm{gm} / \mathrm{cc}$ used for the overlying sediments, Triassic strata and crustal rock, respectively. 


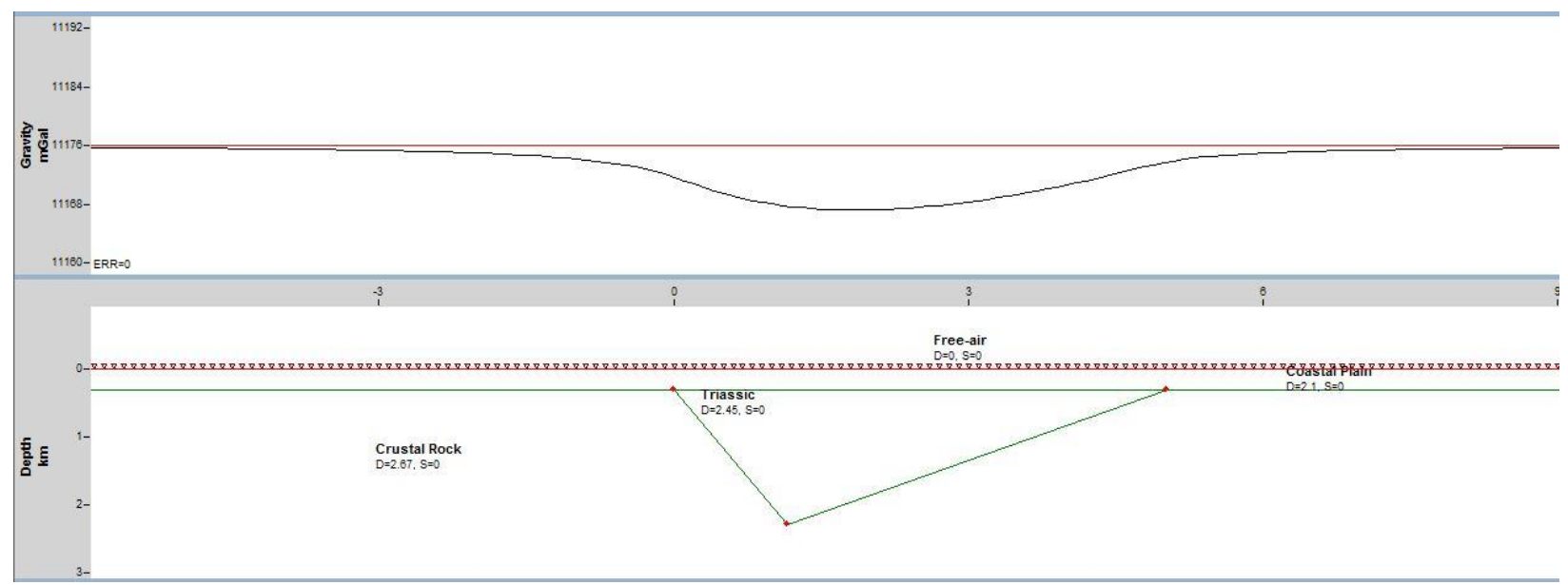

Model C3: $2.0 \mathrm{~km}$ deep basin buried at $0.3 \mathrm{~km}$ and resultant gravity anomaly. Densities of 2.1 $\mathrm{gm} / \mathrm{cc}, 2.45 \mathrm{gm} / \mathrm{cc}$ and $2.67 \mathrm{gm} / \mathrm{cc}$ used for the overlying sediments, Triassic strata and crustal rock, respectively.

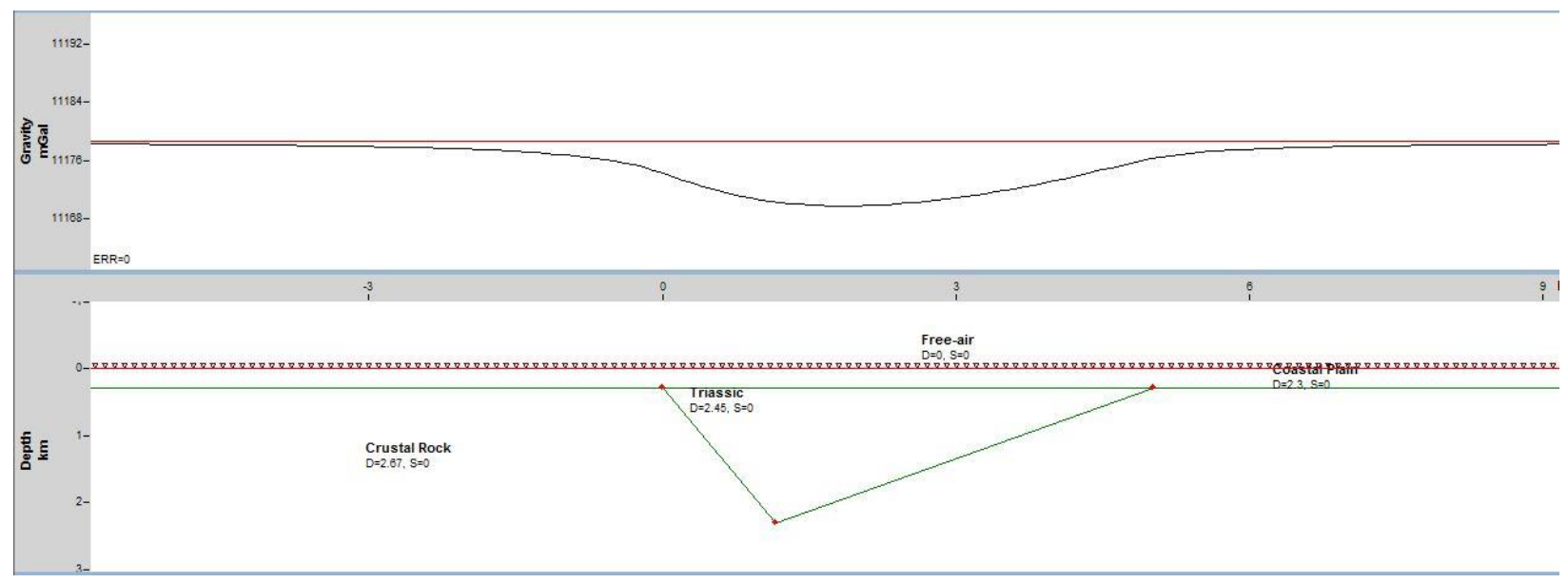

Model C4: $2.0 \mathrm{~km}$ deep basin buried at $0.3 \mathrm{~km}$ and resultant gravity anomaly. Densities of 2.3 $\mathrm{gm} / \mathrm{cc}, 2.45 \mathrm{gm} / \mathrm{cc}$ and $2.67 \mathrm{gm} / \mathrm{cc}$ used for the overlying sediments, Triassic strata and crustal rock, respectively. 


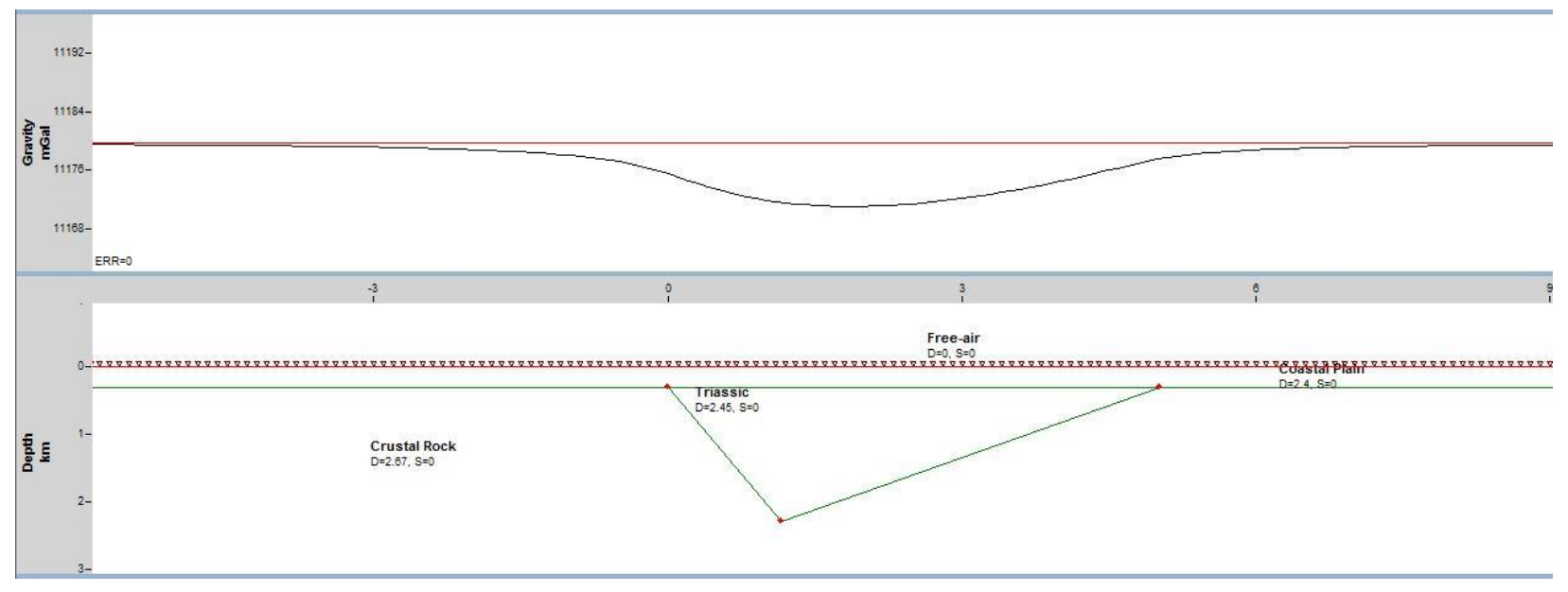

Model C5: $2.0 \mathrm{~km}$ deep basin buried at $0.3 \mathrm{~km}$ and resultant gravity anomaly. Densities of 2.4 $\mathrm{gm} / \mathrm{cc}, 2.45 \mathrm{gm} / \mathrm{cc}$ and $2.67 \mathrm{gm} / \mathrm{cc}$ used for the overlying sediments, Triassic strata and crustal rock, respectively.

\section{Domino-style faulting}

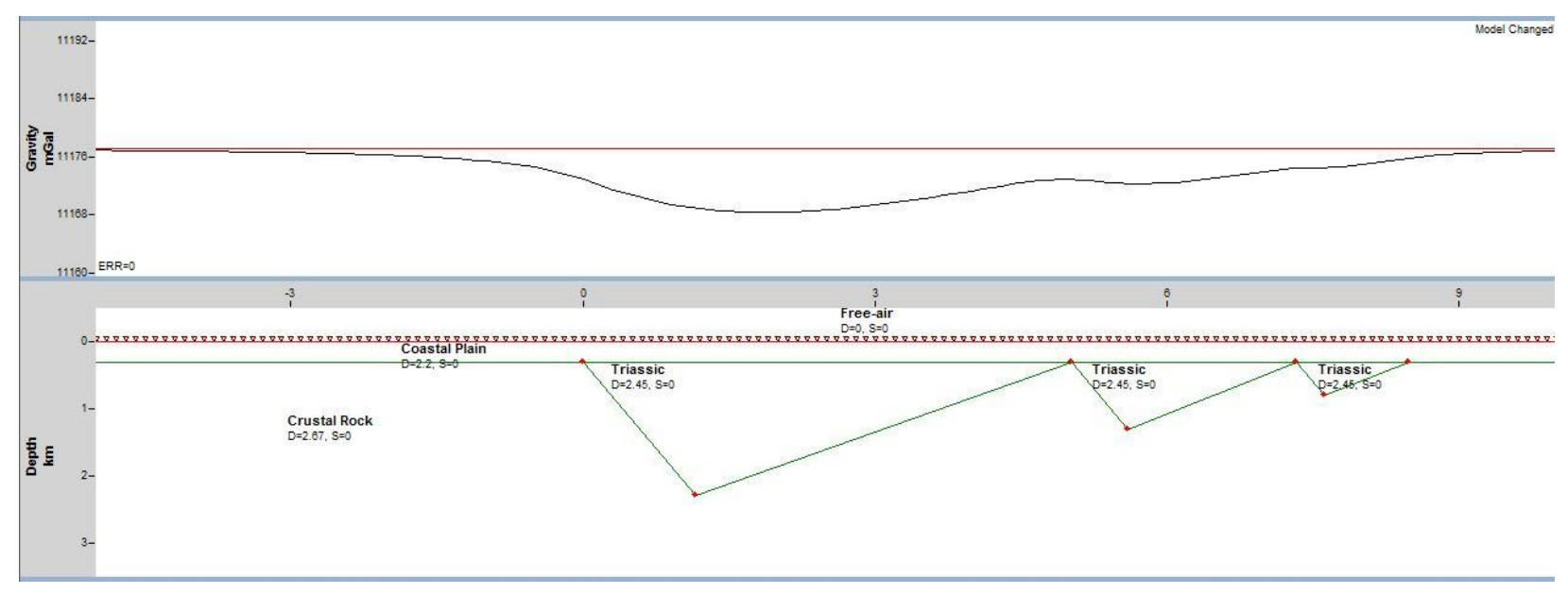

Model D1: Domino-style faulting with a maximum $2.0 \mathrm{~km}$ deep basin in a series buried at 0.3 $\mathrm{km}$ and resultant gravity anomaly. Densities of $2.2 \mathrm{gm} / \mathrm{cc}, 2.45 \mathrm{gm} / \mathrm{cc}$ and $2.67 \mathrm{gm} / \mathrm{cc}$ used for the overlying sediments, Triassic strata and crustal rock, respectively. 
Crustal blocks with density contrast

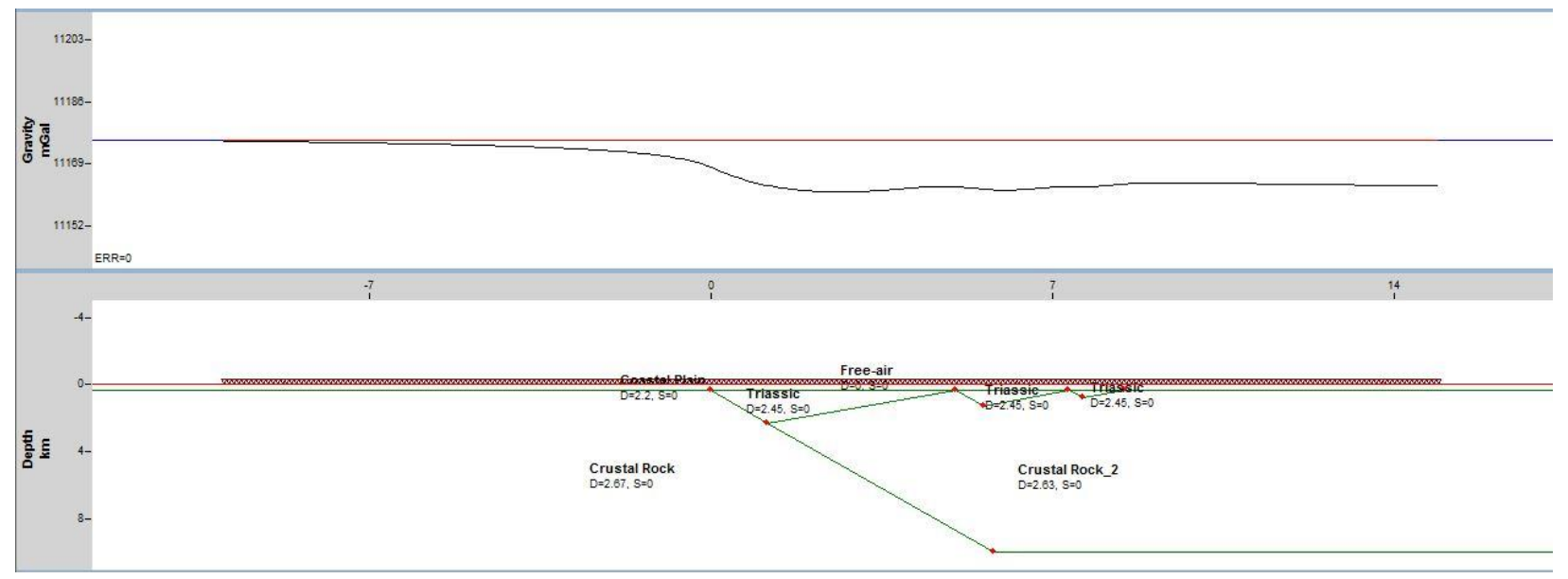

Model D2: Domino-style faulting with a maximum $2.0 \mathrm{~km}$ deep basin in a series exposed at the surface and resultant gravity anomaly. Densities of $2.45 \mathrm{gm} / \mathrm{cc}$ and $2.67 \mathrm{gm} / \mathrm{cc}$ used for the Triassic strata and crustal rock, respectively.

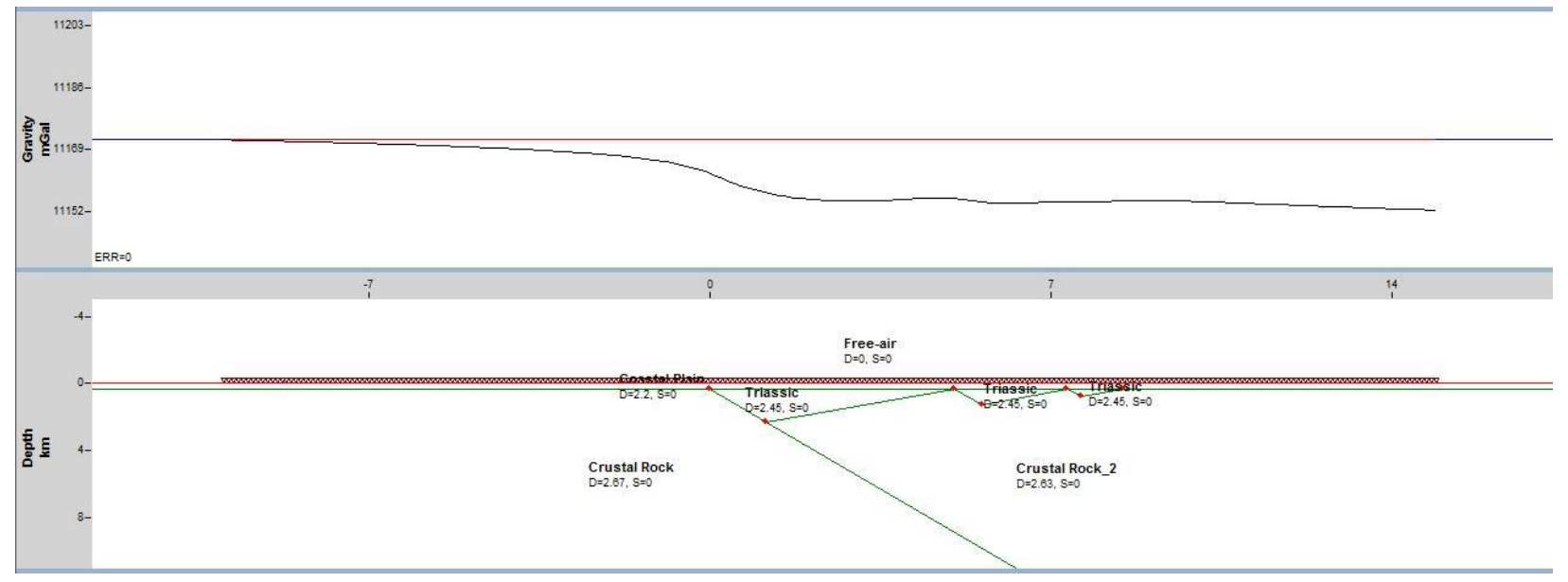

Model D3: Domino-style faulting with a maximum $2.0 \mathrm{~km}$ deep basin in a series buried at a depth of $0.3 \mathrm{~km}$ with a difference of density between crustal blocks and the resultant gravity anomaly. Densities of $2.2 \mathrm{gm} / \mathrm{cc}, 2.45 \mathrm{gm} / \mathrm{cc}$, and $2.65 \mathrm{gm} / \mathrm{cc}$ or $2.67 \mathrm{gm} / \mathrm{cc}$ used for the overlying sediments, Triassic strata and crustal blocks, respectively. 


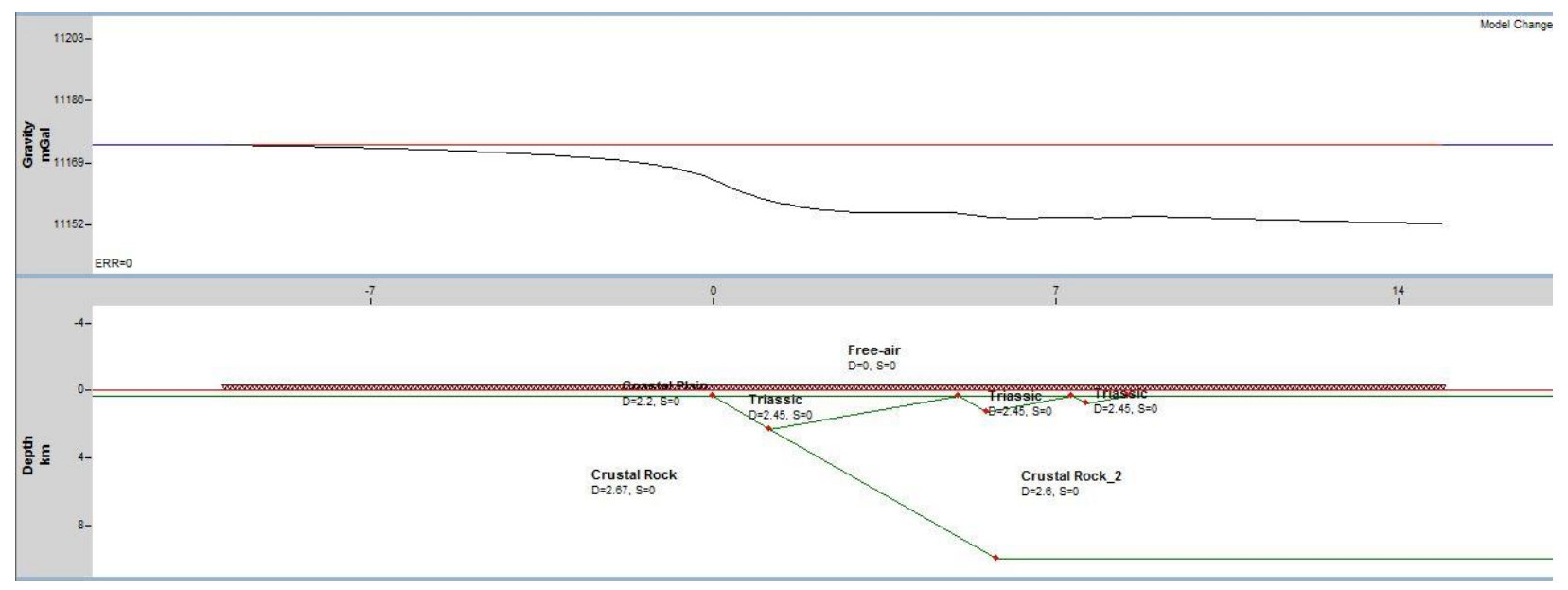

Model D4: Domino-style faulting with a maximum $2.0 \mathrm{~km}$ deep basin in a series buried at a depth of $0.3 \mathrm{~km}$ with a difference of density between crustal blocks and the resultant gravity anomaly. Fault planes out at 10km. Densities of $2.2 \mathrm{gm} / \mathrm{cc}, 2.45 \mathrm{gm} / \mathrm{cc}$, and $2.6 \mathrm{gm} / \mathrm{cc}$ or 2.67 $\mathrm{gm} / \mathrm{cc}$ used for the overlying sediments, Triassic strata and crustal blocks, respectively.

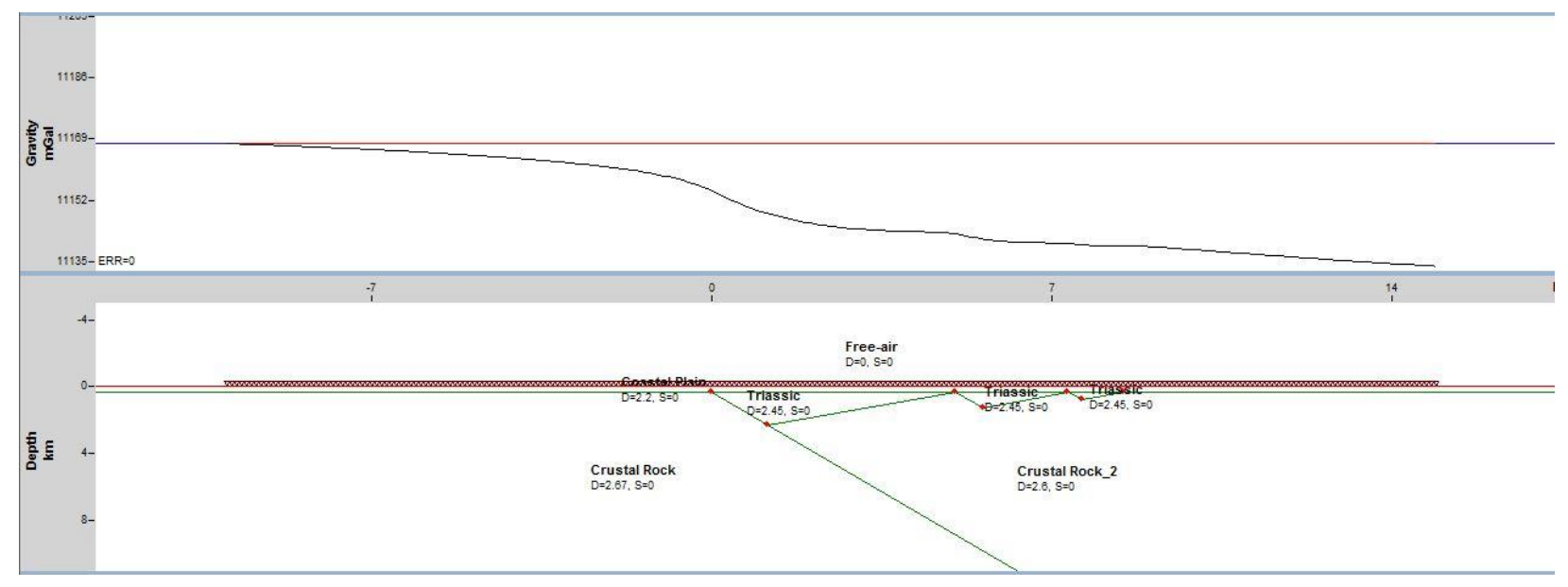

Model D5: Domino-style faulting with a maximum $2.0 \mathrm{~km}$ deep basin in a series buried at a depth of $0.3 \mathrm{~km}$ with a difference of density between crustal blocks and the resultant gravity anomaly. Fault planes out at $20 \mathrm{~km}$. Densities of $2.2 \mathrm{gm} / \mathrm{cc}, 2.45 \mathrm{gm} / \mathrm{cc}$, and $2.65 \mathrm{gm} / \mathrm{cc}$ or 2.67 $\mathrm{gm} / \mathrm{cc}$ used for the overlying sediments, Triassic strata and crustal blocks, respectively. 


\section{Basement for transects}

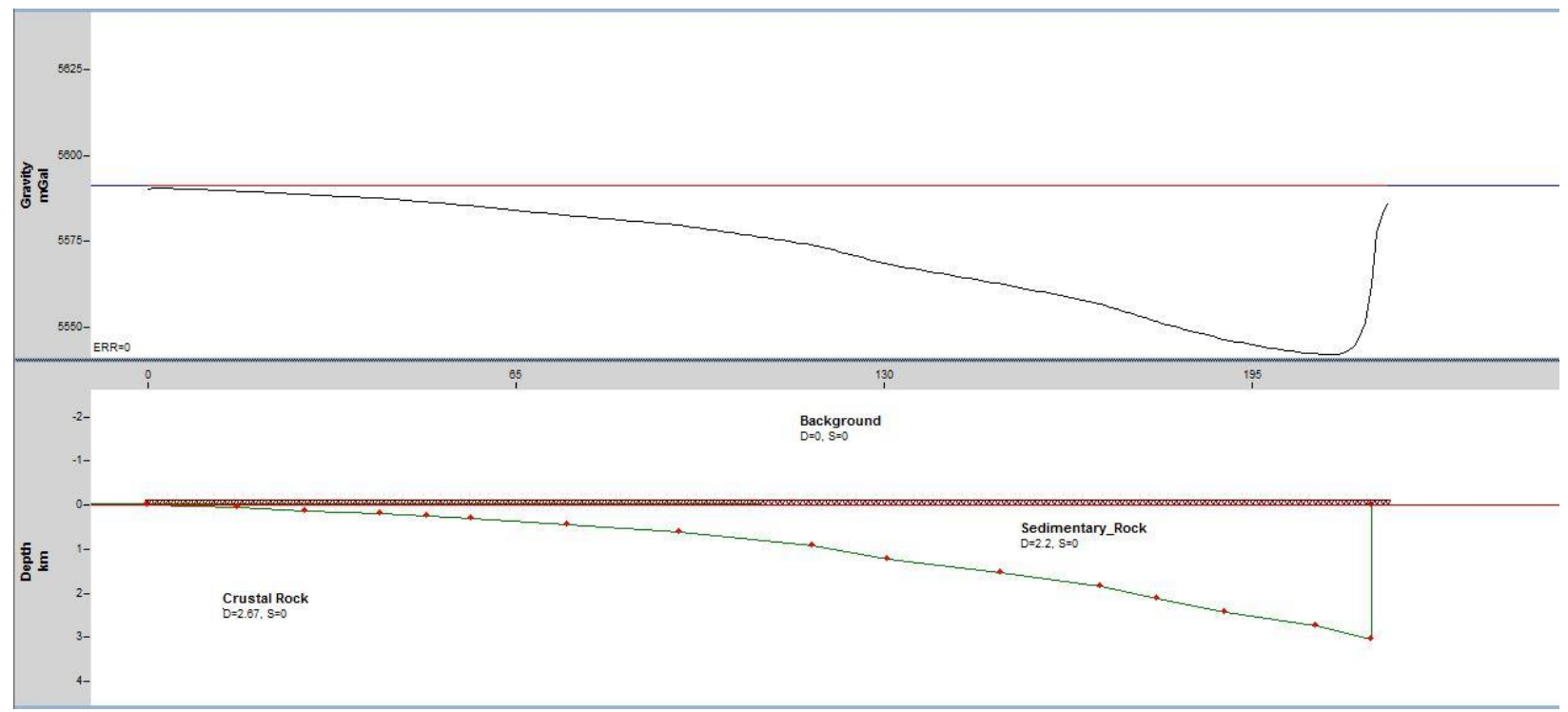

Model D6: Coastal Plain basement rock along Transect AA' and the resultant gravity anomaly. Used for regional anomaly calculation. Densities of $2.2 \mathrm{gm} / \mathrm{cc}$ and $2.67 \mathrm{gm} / \mathrm{cc}$ used for the overlying sediments and crustal blocks, respectively.

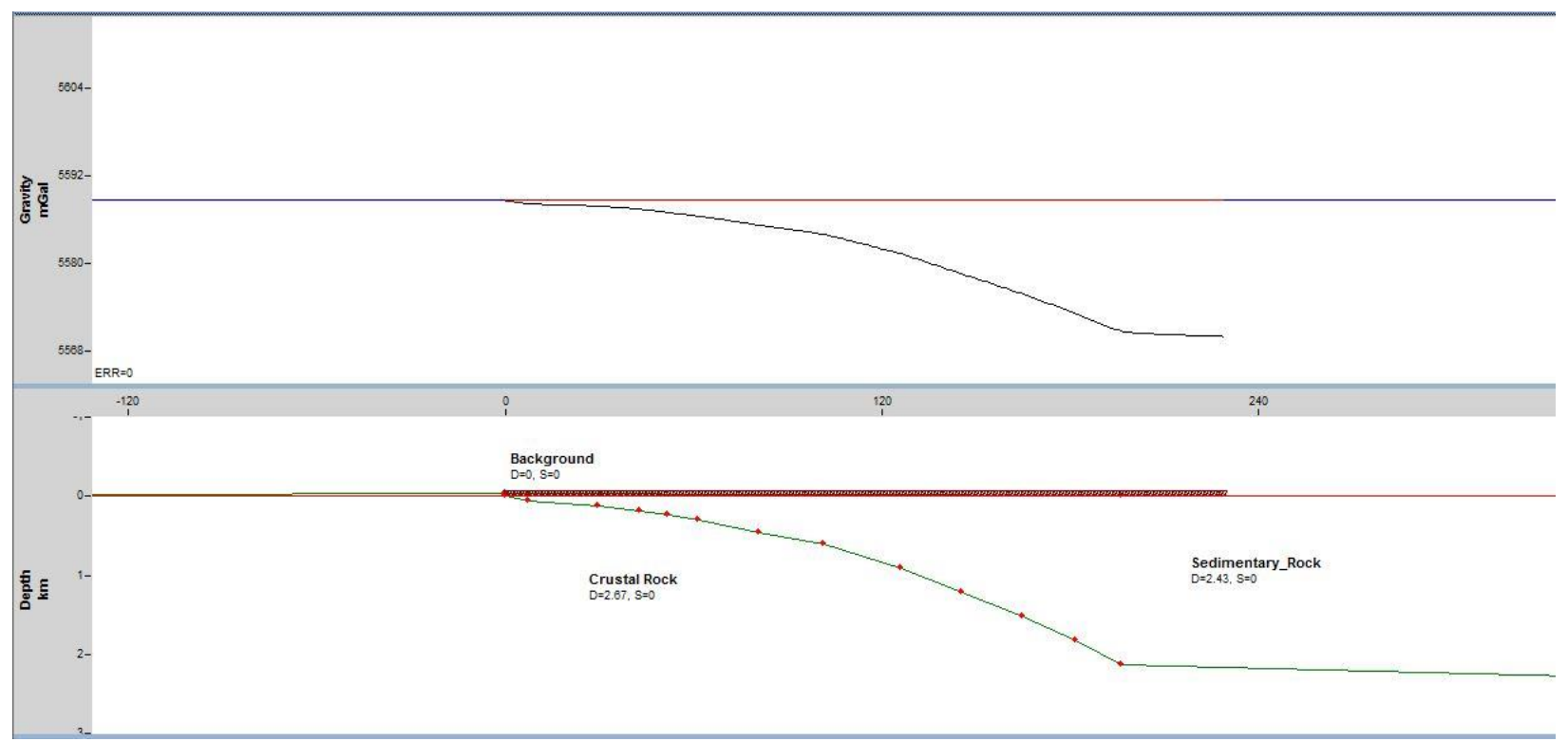

Model D7: Coastal Plain basement rock along Transect BB' and the resultant gravity anomaly. Used for regional anomaly calculation. Densities of $2.2 \mathrm{gm} / \mathrm{cc}$ and $2.67 \mathrm{gm} / \mathrm{cc}$ used for the overlying sediments and crustal blocks, respectively. 


\section{Appendix E: Governing Equations for Correction in Oasis: Montaj}

Gravity formulas used within the Montaj Gravity and Terrain Correction extension. The list of Gravity formulas is provided below:

1. Instrument Scale Factor

2. Tide Correction

3. Instrument Height

4. Drift Correction

5. Absolute Gravity

6. Latitude Correction

7. Free Air Anomaly

8. Bouguer Anomaly

9. Complete Bouguer Anomaly

10. Terrain Correction

1) Instrument Scale Factor- The instrument scale factor corrects a reading to a relative milligal value based on an instrument calibration. The correction can either be constant throughout the instrument range, or it can be derived from a user-supplied calibration table.

Equation 1:

$r_{c}=r * S(r)$

where:

$\mathrm{r}_{\mathrm{c}}=$ Corrected reading in milligals

$\mathrm{r}=$ Instrument reading in dial units

$\mathrm{S}(\mathrm{r})=$ Scale factor (dial units/milligal), which may be a function of the reading 
Table E1: L\&R Model G gravity meter scale factor

\begin{tabular}{rrr} 
Instrument & Milligal & Scale \\
\hline 2900 & 3063.16 & 1.05715 \\
3000 & 3168.88 & 1.0572 \\
3100 & 3274.6 & 1.05724 \\
3200 & 3380.32 & 1.05727 \\
3300 & 3486.05 & 1.05731 \\
3400 & 3591.78 & 1.05735 \\
3500 & 3697.52 & 1.05738 \\
3600 & 3803.25 & 1.0574 \\
3700 & 3908.99 & 1.05743 \\
3800 & 4014.74 & 1.05747 \\
3900 & 4120.48 & 1.05751 \\
4000 & 4226.24 & 1.05754 \\
4100 & 4331.99 & 1.05757 \\
\hline
\end{tabular}

2) Tide Correction- If a relative time difference to Greenwich Mean Time (GMT) is provided on the constants line (via the Hours to GMT (+ in W parameter), all readings are corrected for earth tides due to the position of the sun and the moon at the time and location of the observation. The full formula is too complex to list here, but can be obtained from the Dominion Observatory of Canada.

Equation 2:

$r_{t}=r_{c}+g_{\text {tide }}$

where:

$\mathrm{r}_{\mathrm{t}}=$ Tide corrected reading

$\mathrm{r}_{\mathrm{c}}=$ Scale corrected reading (from the previous "Instrument Scale Factor" correction equation).

$\mathrm{g}_{\text {tide }}=$ Tide correction 
3) Instrument Height- Each reading is corrected for the height of the instrument above the station or base at which the elevation is measured.

\section{Equation 3:}

$r_{h}=r_{t}+0.308596 h_{i}$

where:

$\mathrm{r}_{\mathrm{h}}=$ Instrument height corrected reading

$\mathrm{r}_{\mathrm{t}}=$ Tide corrected reading (from the previous "Tide Correction" equation).

$h_{i}=$ Instrument height in metres

4) Drift Correction- A drift is calculated based on the closure error between the first and last base reading in each loop.

\section{Equation 4:}

$d=\frac{\left(r_{b 2}-r_{b 1}\right)-\left(g_{b 2}-g_{b 1}\right)}{t_{b 2}-t_{b 1}}$

where:

$\mathrm{d}=$ Drift reading in milligals/hour

$\mathrm{r}_{\mathrm{b} 1}=$ Base 1 reading

$\mathrm{t}_{\mathrm{b} 1}=$ Base 1 time

$\mathrm{g}_{\mathrm{b} 1}=$ Base 1 absolute $\mathrm{G}$ in milligals 
$\mathrm{r}_{\mathrm{b} 2}=$ Base 2 reading

$\mathrm{t}_{\mathrm{b} 2}=$ Base 2 time

$\mathrm{g}_{\mathrm{b} 2}=$ Base 2 absolute $\mathrm{G}$ in milligals

5) Absolute Gravity- The absolute gravity is the earth's gravitational attraction at the observed station.

Equation 5:

$\mathrm{g}_{\mathrm{a}}=\mathrm{g}_{\mathrm{b} 1}+\left(\mathrm{r}_{\mathrm{h}}-\mathrm{r}_{\mathrm{b} 1}\right)-\left(\mathrm{t}-\mathrm{t}_{\mathrm{b} 1}\right) * \mathrm{~d}$

where:

$\mathrm{g}_{\mathrm{a}}=$ Absolute gravity in milligals

$\mathrm{g}_{\mathrm{b} 1}=$ Base 1 absolute $\mathrm{G}$ in milligals

$\mathrm{r}_{\mathrm{h}}=$ Instrument height corrected station reading (from the previous "Instrument Height" correction equation).

$\mathrm{rb} 1=$ Base 1 reading

$\mathrm{t}=$ Reading time

tb1 $=$ Base 1 reading time

$\mathrm{d}=$ Drift, from Drift Correction (in milligals/hour)

6) Latitude Correction- The latitude correction requires the theoretical gravity at the station location on the earth's spheroid. There are three optional formulas for the theoretical gravity. 


\section{Formula}

$\mathrm{G}_{1}=978049 *\left[1+0.0052884 \sin ^{2}(1)-0.0000059 \sin ^{2}(1)\right]$

\section{Formula}

$\mathrm{G}_{1}=978031.846 *\left[1+0.005278895 \sin ^{2}(1)+0.000023462 \sin ^{4}(1)\right]$

\section{Formula}

$\mathrm{G}_{1}=978032.7 *\left[1+0.0053024 \sin ^{2}(1)-0.0000058 \sin ^{2}(21)\right]$

where:

$\mathrm{G}_{1}=$ Theoretical gravity in milligals (latitude correction)

$1=$ Latitude of the station

7) Free Air Anomaly- The free air correction is calculated by subtracting the latitude correction (theoretical gravity) from the absolute gravity and adding a correction for the station elevation.

Equation 7:

$\mathrm{g}_{\mathrm{fa}}=\mathrm{g}_{\mathrm{a}}-\mathrm{g}_{1}+0.308596 \mathrm{~h}_{\mathrm{s}}$

where:

$\mathrm{g}_{\mathrm{fa}}=$ Free air anomaly in milligals

$\mathrm{g}_{\mathrm{a}}=$ Absolute gravity (from the previous "Absolute Gravity" correction equation). 
$\mathrm{g}_{\mathrm{l}}=$ Latitude correction from the Latitude Correction equation

$\mathrm{h}_{\mathrm{s}}=$ Station elevation in meters

8) Bouguer Anomaly- The Bouguer anomaly corrects the free air anomaly for the mass of rock that exists between the station elevation and the spheroid:

Equation 8:

$\mathrm{g}_{\mathrm{ba}}=\mathrm{g}_{\mathrm{fa}}-0.0419088^{*}\left[\rho \mathrm{h}_{\mathrm{s}}+\left(\rho_{\mathrm{w}}-\rho\right) \mathrm{h}_{\mathrm{w}}+\left(\rho_{\mathrm{i}}-\rho_{\mathrm{w}}\right) \mathrm{h}_{\mathrm{i}}\right]-\mathrm{g}_{\text {curv }}$

where:

$\mathrm{g}_{\mathrm{ba}}=$ Bouguer anomaly in milligals

$\mathrm{g}_{\mathrm{fa}}=$ Free air anomaly (from the previous "Free Air Anomaly" correction equation).

$\rho=$ Bouguer density of rock in $\mathrm{g} / \mathrm{cc}$

$\rho_{\mathrm{w}}=$ Bouguer density of water $\mathrm{g} / \mathrm{cc}$

$\rho_{\mathrm{i}}=$ Bouguer density of ice in $\mathrm{g} / \mathrm{cc}$

$\mathrm{h}_{\mathrm{s}}=$ Station elevation in meters

$\mathrm{h}_{\mathrm{w}}=$ Water depth in meters (including ice)

$\mathrm{h}_{\mathrm{i}}=$ Ice thickness in meters

$\mathrm{g}_{\text {curv }}=$ Curvature correction

The purpose of the curvature correction as a step in producing the Bouguer anomaly is to convert the geometry for the Bouguer correction from an infinite slab to a spherical cap (LaFehr, 1991). 
9) Complete Bouguer Anomaly- The Complete Bouguer anomaly corrects the Bouguer anomaly for irregularities of the earth due to terrain in the vicinity of the observation point.

Equation 9:

$\mathrm{g}_{\mathrm{cba}}=\mathrm{g}_{\mathrm{ba}}+\mathrm{g}_{\mathrm{tc}}$

where:

$\mathrm{g}_{\mathrm{cba}}=$ Complete Bouguer Anomaly in milligals

$\mathrm{g}_{\mathrm{ba}}=$ Bouguer Anomaly (from the previous "Bouguer Anomaly" correction equation).

$\mathrm{g}_{\mathrm{tc}}=$ Supplied terrain correction in milligals

10) Terrain Correction- The calculation of the regional correction (beyond 1000m) has been identified as the most computationally expensive component of terrain correction calculations. The Oasis Montaj Gravity and Terrain Correction system addresses this by calculating the regional terrain correction from a coarse regional Digital Elevation Model (DEM) draped over a more finely sampled local DEM model that covers a survey area. This produces a "regional correction grid" that represents terrain corrections beyond a local correction distance and this can be re-used to calculate detailed corrections at each observed gravity location.

To calculate local corrections, the local DEM data is "sampled" to a grid mesh centered on the station to be calculated. The correction is calculated based on near-zone, intermediatezone and far-zone contributions. In the near zone ( 0 to 1 cells from the station), the algorithm sums the effects of four sloping triangular sections, which describe a surface between the gravity 
station and the elevation at each diagonal corner. If a slope is provided for each station in the input data file, the slope of the triangular sections is assumed to be the same as the station slope, regardless of the grid topography values. This is reasonable since topography grids may not be as accurate as a locally measure slope. The terrain grid should ideally cover an area as large as the gravity survey plus a reasonable distance beyond which the terrain effect is negligible. This distance depends on the severity of the terrain, and the detail of anomalies under investigation. A distance of 167 kilometres is recommended, using a large regional DEM.

\section{Terrain Correction Formulas}

This section contains, illustrates, and lists the equations used to calculate terrain correction in each zone.

\section{Zone 0: Sloped Triangle}

$$
g=G D \phi\left(R-\sqrt{R^{2}+H^{2}}+\frac{H^{2}}{\sqrt{R^{2}+H^{2}}}\right)
$$

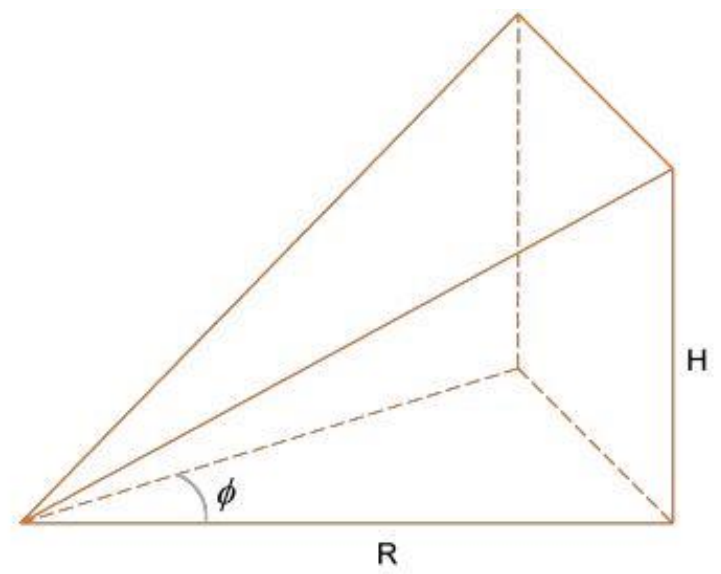


Zone 1: Prism

$g=-G D\left|Z_{Z_{1}}^{Z_{2}}\right| Y_{Y_{1}}^{Y_{2}}\left|X_{X_{1}}^{X_{2}} x \bullet \ln (y+R)+y \bullet \ln (x+R)+Z \arctan \frac{Z \bullet R}{x \bullet y}\right|||$

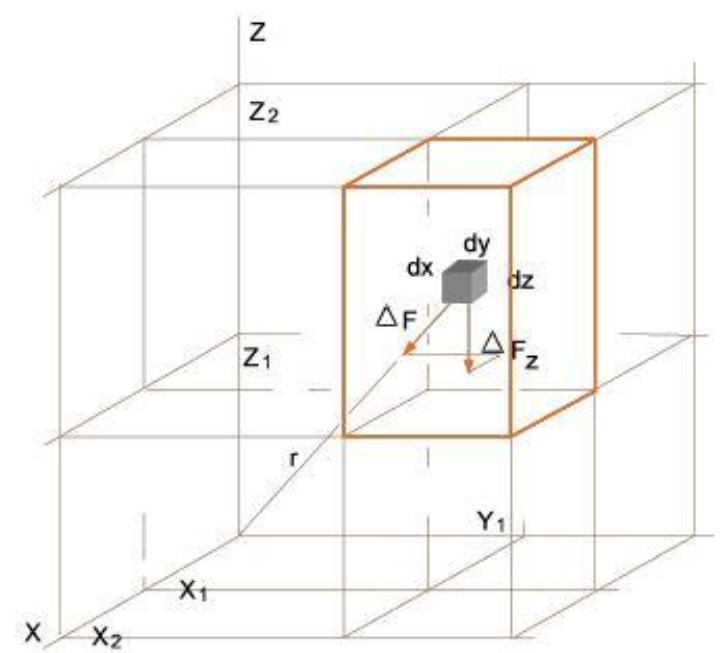

The Gravitational Attraction of a Right Rectangular Prism 
Zone 2 (and beyond): Sectional Ring

$g=2 G D A^{2} \frac{\left(R_{2}-R_{1} \sqrt{R_{1}{ }^{2}+H^{2}}-\sqrt{R_{2}{ }^{2}+H^{2}}\right.}{\left(R_{2}{ }^{2}-R_{1}^{2}\right)}$ where,

$\mathrm{g}$ = gravity attraction

$\mathrm{G}=$ gravitational constant

$\mathrm{D}=$ density

$A=$ length of horizontal side of prism

$R_{1}=$ radius of inner circle of annular ring

$\mathrm{R}_{2}=$ radius of outer circle of annular ring

$\mathrm{H}=$ height of annular ring or prism

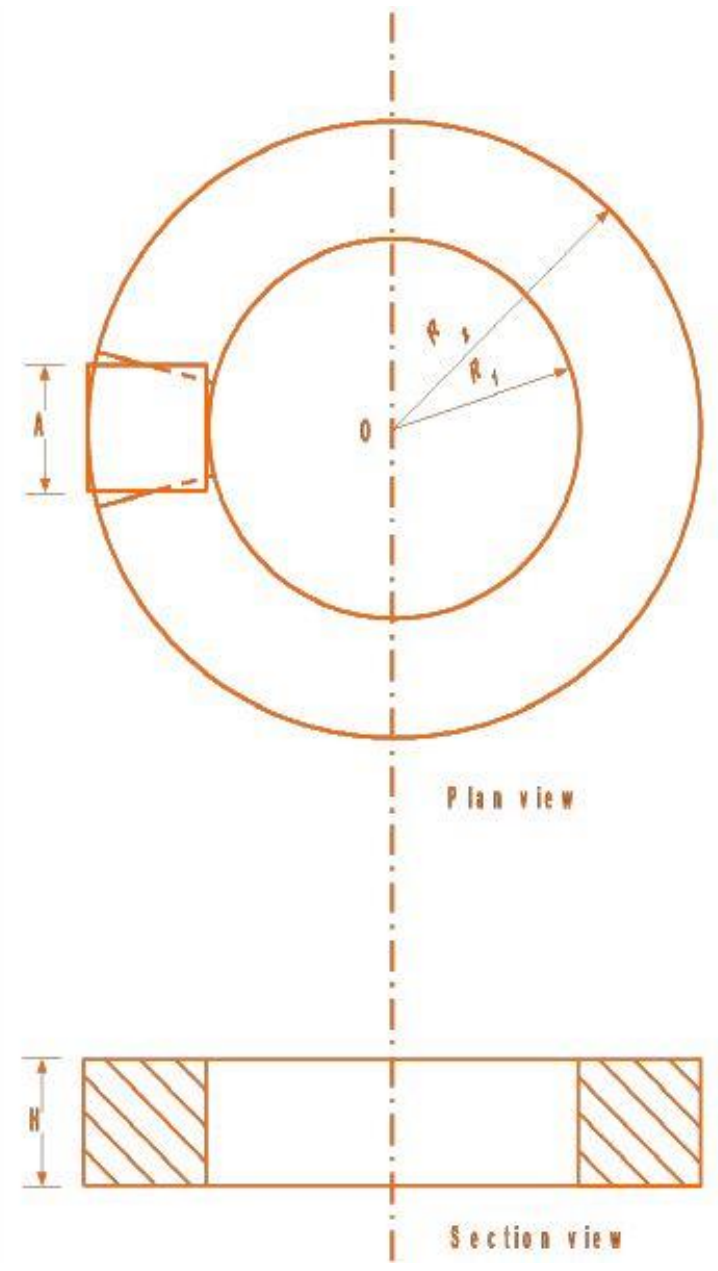


